\title{
MONITORAMẼNTO DA QUALIDADE DA ÁGUA DAS ZONAS NÃO SATURADA E SATURADA EM ÁREA DE FERTIRRIGAÇÃO COM VINHAÇA
}

\author{
Elton Gloeden
}

Orientador: Prof. Dr. Robert William Cleary

\begin{abstract}
DISSERTAÇÃO DE MESTRADO
Programa de Pós-Graduação em Recursos Minerais e Hidrogeologia
\end{abstract}


UNIVERSIDADE DE SẢO PAULO

INSTITUTO DE GEOCIENCIAS

\section{MONITORAMENTO DA QUALIDADE DA ÁGUA DAS ZONAS NĀO SATURADA E SATURADA EM ÁREA DE FERTIRRIGAÇĀO COM VINHAÇA}

Elton Gloeden

Orientador: Prof. Dr. Robert William Cleary

DISSERTAÇÃO DE MESTRADO

COMISSÃO JULGADORA

nome

Presidente:

Dr.J.M.B.Mendes

Examinadores:
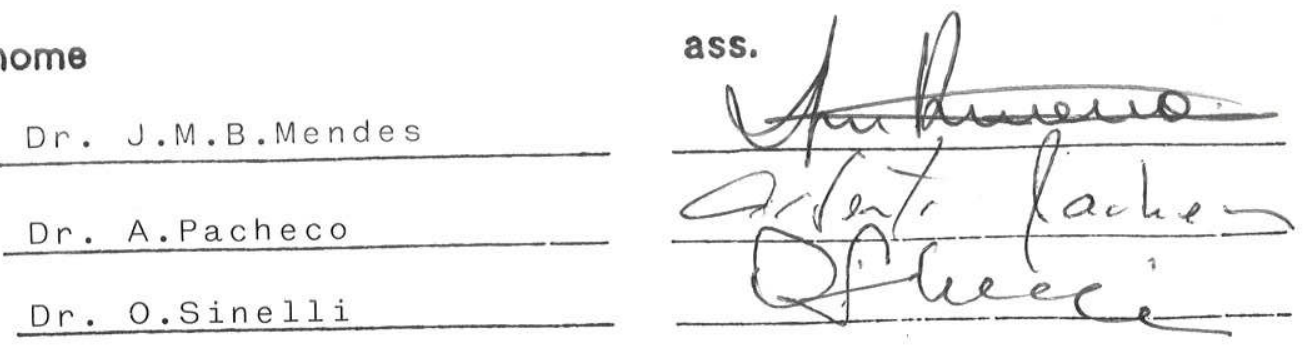
UNIVERSIDADE DE SĀO PAULO

INSTITUTO DE GEOCIENCIAS

DEDALUS - Acervo - IGC

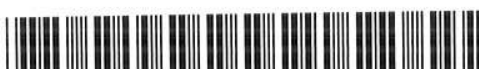

30900005034

\title{
MONITORAMENTO DA QUALIDADE DA ÁGUA DAS ZONAS NĀO SATURADA E SATURADA EM ÁREA DE FERTIRRIGAÇĀO COM VINHAÇA
}

\author{
Elton Gloeden
}

Orientador: Prof. Dr. Robert William Cleary

\section{DISSERTAÇÃO DE MESTRADO}

Programa de Pós-Graduação em Recursos Minerais e Hidrogeologia

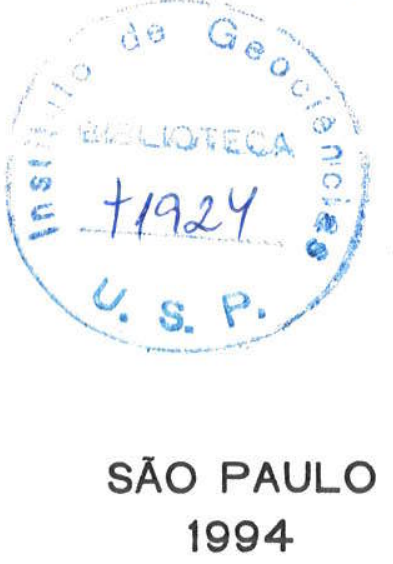


Dedico este trabalho aos meus Pais e Irmãos e especialmente à Célia e Carolina 


\section{AGRADECIMENTOS}

Ao Dr. Robert W. Cleary (PhD.) pela orientação na confecção desta dissertação e pelo incentivo ao desenvolvimento de pesquisas e pela formação de profissionais brasileiros na área da Hidrogeologia Aplicada à Poluição.

Ao Eng ${ }^{\circ}$ Rodrigo César de Araújo Cunha (MS), Gerente do Setor de Pesquisas de Resíduos Industriais (DTRR) da CETESB (Companhia de Tecnologia de Saneamento Ambiental), pela viabilização do estudo realizado, pelo apoio constante, discussões e sugestões proveitosas.

À Dra. Dorothy Carmem Pinatti Casarini, pelas sugestões apresentadas e pelo apoio nos momentos finais desta dissertação.

Ao Instituto de Geociências da Universidade de São Paulo, Departamento de Geologia Econômica e Geofísica Aplicada e ao Centro de Pesquisas de Águas Subterrâneas (CEPAS) pelo apoio recebido.

À Companhia de Tecnologia de Saneamento Ambiental (CETESB) por possibilitar a realização deste estudo através de suporte financeiro, apoio logístico, técnico e laboratorial.

Agradecimentos especiais aos funcionários do Setor de Pesquisas de Resíduos Industriais desta Companhia, que participaram diretamente do estudo: Maria José de Barros Fraccaroli, pelos ensinamentos na área de informática; Vicente de Aquino Neto, pelos trabalhos de laboratório executados para a construção das curvas de retenção de água; Agnaldo Ribeiro de Vasconcellos, Glauco Tavares Carmona e Darci Andrade Oliveira, pelos trabalhos de campo; Wagner França Aquino, pelo auxílio na interpretação dos dados geofísicos. A estes e aos demais funcionários do DTRR, agradecimentos pela amizade e paciência.

Ao Professor Dr. José Milton Benetti Mendes pela orientação na execução dos trabalhos geofísicos de campo e também na interpretação dos dados.

Ao Professor Dr. Osmar Sinelli pelas informações e orientação na escolha da área de estudo. 


\section{ÍNDICE}

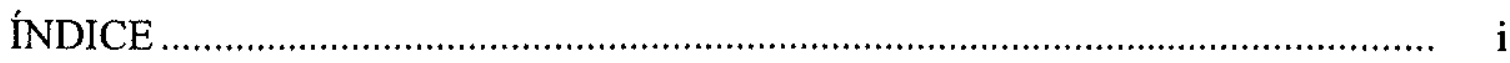

LISTA DE FIGURAS ....................................................................................... iv

LISTA DE TABELAS ................................................................................ vi

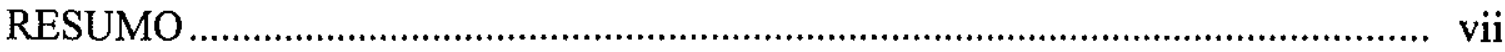

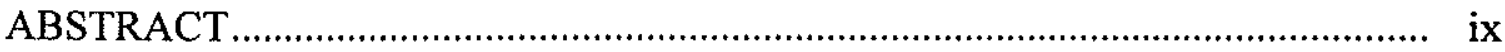

1- INTRODUÇÃO

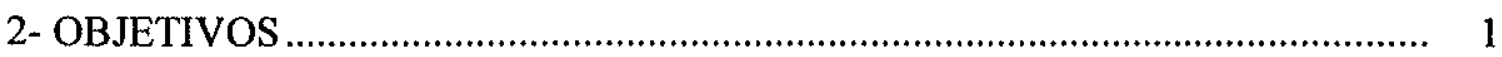

3- REVISÃO BIBLIOGRÁFICA ……………………................................. 2

3.1- A vinhaça ....................................................................................... 2

3.1.1- Histórico indústria sucro-alcooleira no Brasil........................... 2

3.1.2- Composição da vinhaça............................................................ 3

3.1.3- Potencial poluidor e disposição final da vinhaça ........................ 4

3.1.4- Estudos na área de poluição dos solos e das águas subterrâneas ...................................................................... 6

3.2- As zonas não saturada e saturada .................................................... $\quad 8$

3.2.1- A fase sólida ................................................................. 9

3.2.2- Distribuição de fluídos nas zonas não saturada e saturada......... 10

3.2.3- Energia da água nas zonas não saturada e saturada.................... 11

3.2.4- Curva de retenção solo-água .................................................. 15

3.2.5- Fluxo da água sob condição não saturada e saturada ................. 20

3.2.6- Condutividade Hidráulica ...................................................... 21

3.2.7- Fluxo preferencial na zona não saturada ................................... 23

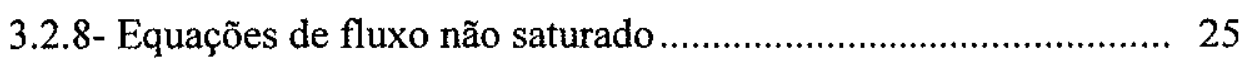

3.3- Movimento de solutos na zona não saturada .......................................... 27

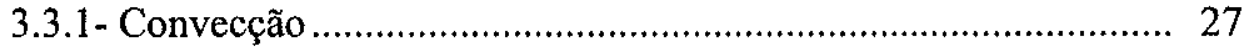

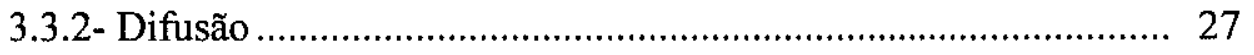

3.3.3- Dispersão Hidrodinâmica........................................................ 29

3.3.4- Difusão + dispersão............................................................ 30

3.3.5- Fontes e sumidouros................................................................ 31

3.3.5.1- Modelos de equilíbrio de transporte de massa ............ 31

3.3.5.2- Modelos de transporte de massa não equilíbrio .......... 32

3.3.5.3- Exclusão de ânions ..................................................... 33

3.4- Monitoramento da Zona Não Saturada .................................................. 35

3.4.1- Monitoramento das propriedades de armazenamento ................ 36

3.4.1.1- Espessura …………………………………........ 36 
3.4.1.3- Porosidade

3.4.1.4- Conteúdo de água e potencial matricial da água na zona não saturada 37

3.4.2- Monitoramento das propriedades transmissão (fluxo) 41

3.4.2.1 - Medidas de campo das taxas de infiltração ................ 42

3.4.2.2- Calculo do fluxo e velocidade de fluxo..................... 43

3.4.3- Monitoramento da qualidade da água na zona não saturada..... 44

3.4.3.1- Métodos indiretos................................................... 45

3.4.3.2- Amostragem do solo............................................... 45

3.4.3.3- Amostragem da água da zona não saturada................. 45

3.4.3.3.1- Coleta por vácuo ...................................... 46

3.4.3.3.2- Amostradores de drenagem livre................ 53

3.5- Monitoramento da zona saturada ...................................................... 54

3.5.1- Poços de monitoramento e piezômetros................................... 54

3.5.2 Locação e número de poços de monitoramento e piezômetros.. 56

3.5.3- Amostragem .............................................................. 57

3.6- Geologia Regional ................................................................... 58

3.7- Hidrogeologia e Hidrogeoquímica Regionais.................................... 60

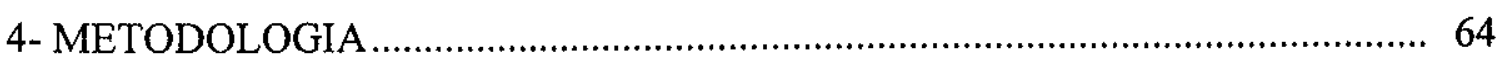

4.1- Seleção da área de estudo................................................................. 64

4.2- Caracterização geológica e hidrogeológica local ................................. 66

4.2.1 - Caracterização da zona saturada.......................................... 67

4.2.2 - Caracterização da zona não saturada..................................... 70

4.2.3- Investigações geofísicas .................................................... 72

4.3 - Instalação dos equipamentos de monitoramento................................... 75

4.3.1 - Instalação dos equipamentos de monitoramento da zona não saturada ........................................................................... 75

4.3.2- Instalação dos equipamentos de monitoramento da zona

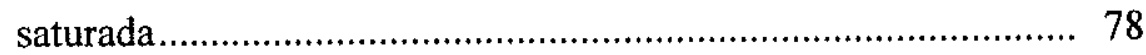

4.4- Aplicação da vinhaça na área de estudo .............................................. 79

4.5- Monitoramento das zonas não saturada e saturada ................................ 80

5- APRESENTAÇÃO E INTERPRETAÇÃO DOS RESULTADOS....................... 81

5.1- Fluxo de água na zona saturada ...................................................... 81

5.2- Fluxo de água na zona não saturada................................................ 83

5.3 - Comportamento dos constituintes da vinhaça nas zonas não saturada e

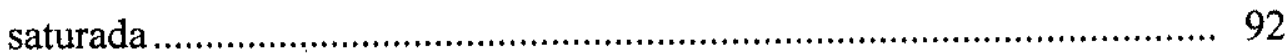

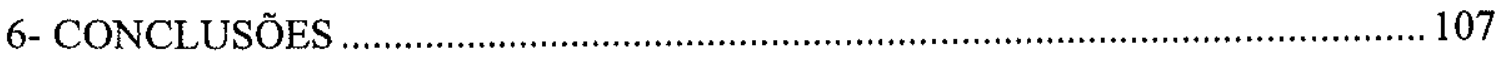




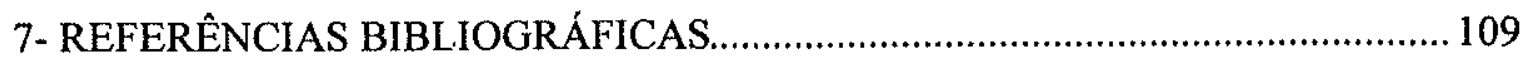

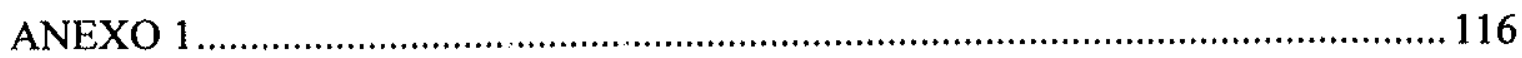

ANEXO 2

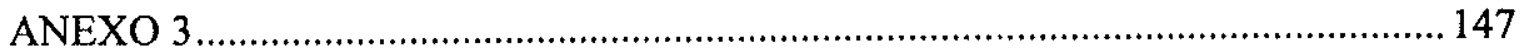




\section{LISTA DE FIGURAS}

Figura 3.1 - Curva de retenção do solo-água ...................................................... 16

Figura 3.2 - Curva de retenção para solos arenoso e argiloso.................................... 16

Figura 3.3 - Efeito da compactação do solo na curva de retenção .............................. 17

Figura 3.4 - Efeito "Ink Bottle"......................................................................... 18

Figura 3.5 - Efeito da histerese ...................................................................... 19

Figura 3.6 - Tensiômetro................................................................................ 38

Figura 3.7 - Lisímetro de sucção...................................................................... 47

Figura 3.8 - Esquema de instalação do pan-lisímetro ………………….................. 54

Figura 3.9 - Esquema de construção e instalação de multiníveis.................................. 58

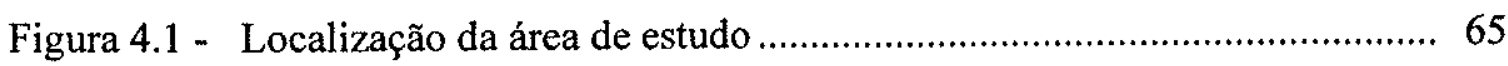

Figura 4.2 - Esquema da área de estudo .............................................................. 66

Figura 4.3 - Poço de monitoramento com filtro longo ............................................... 68

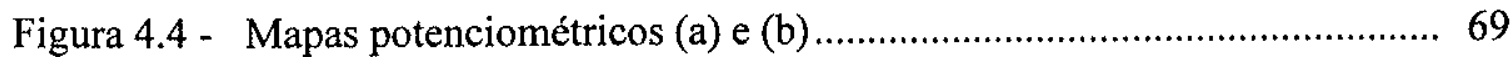

Figura 4.5 - Curvas de retenção de água ............................................................... 71

Figura 4.6 - Sondagem elétrica 1 .................................................................. 74

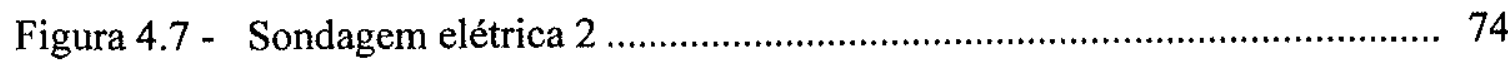

Figura 4.8 - Esquema de construção e instalação dos tensiômetros.............................. 75

Figura 4.9 - Esquema de construção e instalação dos lisímetros de sucção................. 77

Figura 4.10 - Esquema de construção e instalação dos poços de monitoramento

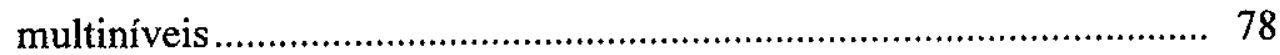

Figura 5.1 - Potencial hidráulico nos multiníveis ………...................................... 81

Figura 5.2 - "Slug test" ............................................................................ 83

Figura 5.3 - Potencial hidráulico na zona não saturada (3/5/89 a 29/7/89)............... 86

Figura 5.4 - Potencial hidráulico na zona não saturada (1/11/89 a 12/12/89) ........... 88

Figura 5.5 - Conteúdo de água na zona não saturada (3/5/89 a 29/7/89) ................. 89

Figura 5.6 - Conteúdo de água na zona não saturada (1/11/89 a 12/12/89) ............. 90

Figura 5.7 - Condutividade hidráulica: (a) 3/05/89 a 29/07/89 e (b) 1/11/89 a

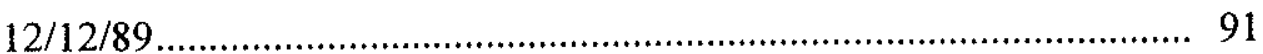

Figura 5.8 - Distribuição de cloreto na zona não saturada .......................................... 93

Figura 5.9 - Distribuição de cloreto na zona saturada............................................... 94

Figura 5.10 - Distribuição de COD na zona não saturada........................................... 95

Figura 5.11 - Distribuição de COD na zona saturada .............................................. 96

Figura 5.12 - Distribuição de sulfato na zona não saturada ....................................... 97

Figura 5.13 - Distribuição de sulfato na zona saturada ............................................. 98

Figura 5.14 - Distribuição de potássio na zona não saturada ....................................... 99 
Figura 5.15 - Distribuição de potássio na zona saturada........................................ 100

Figura 5.16 - Distribuição de nitrogênio amoniacal na zona não saturada .................. 101

Figura 5.17 - Distribuição de nitrogênio amoniacal na zona saturada ......................... 102

Figura 5.18 - Distribuição de NKT na zona não saturada....................................... 103

Figura 5.19 - Distribuição de NKT na zona saturada............................................... 104

Figura 5.20 - Distribuição de nitrogênio nitrato na zona não saturada ....................... 105

Figura 5.21 - Distribuição de nitrogênio nitrato na zona saturada ............................... 106 


\section{LISTA DE TABELAS}

Tabela 3.1 - Evolução da produção de álcool no Brasil .......................................... 3

Tabela 3.2 - Composição química da vinhaça.................................................... 4

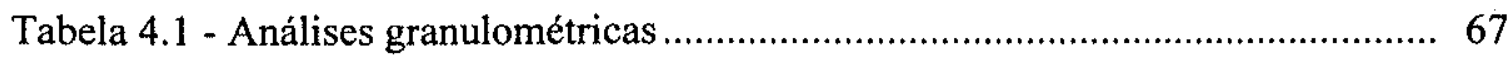

Tabela 4.2 - Características dos poços de monitoramento com filtro longo ................ 68

Tabela 4.3 - Medidas de nivel d'água e potencial hidráulico nos poços de monitoramento ................................................................................ 70

Tabela 4.4 - Resultados dos caminhamentos eletromagnéticos .............................. 73

Tabela 4.5 - Características dos multiníveis ......................................................... 79

Tabela 4.6 - Análises químicas da vinhaça aplicada ............................................. 80

Tabela 5.1 - Potencial hidráulico nos multiníveis ................................................... 82

Tabela 5.2 - Parâmetros de van Genuchten calculados pelo RETC........................... 84 


\section{RESUMO}

A vinhaça, principal resíduo gerado na fabricação de álcool e açúcar, tem sido amplamente utilizada nas lavouras de cana-de-açúcar como uma fonte de nutrientes, principalmente o potássio, substituindo fertilizantes químicos. Várias pesquisas demonstraram sua eficiência como fertilizante, entretanto são escassas as pesquisas verificando o comportamento dos seus constituintes nas zonas não saturada e saturada.

O principal produtor de álcool e açúcar do Brasil é o Estado de São Paulo, que possue extensas áreas de plantações de cana-de-açúcar, as quais são submetidas constantemente ao processo denominado fertirrigação. Estas plantações estão localizadas sobre os aqüíferos Botucatu e Bauru, que são os principais do Estado de São Paulo.

Este estudo foi desenvolvido em um lugar selecionado sobre a área de afloramento da Formação Botucatu, ocupado com plantação de cana-de-açúcar, visando verificar o comportamento dos constituintes da vinhaça nas zonas não saturada e saturada e avaliar os métodos de monitoramento das zonas não saturada e saturada utilizados, em área submetida à fertirrigação.

A área de estudo selecionada foi submetida a uma caracterização geológica e hidrogeológica utilizando-se amostras de solo e/ou sedimentos coletadas em sondagens executadas com trados manuais, para determinação da constituição mineralógica e granulométrica das zonas não saturada e saturada. Foram coletadas também amostras indeformadas, em trincheiras escavadas na área, para confecção das curvas de retenção de água na zona não saturada.

Poços de monitoramento foram instalados para determinação das variações do nível e sentidos de fluxo das águas subterrâneas. Estes dados foram úteis para a locação dos demais equipamentos de monitoramento e as áreas de aplicação de vinhaça. Com o intuito de obter-se medidas de potencial hidráulico e amostras de água para análises químicas puntuais da zona saturada foram instalados poços de monitoramento tipo multinível.

$\mathrm{Na}$ zona não saturada foram instalados tensiômetros para determinação dos padrões de fluxo de água nesta zona e lisímetros de sucção visando a coleta de amostras de água para análise químicas. Foram instalados também panlisímetros com o intuito de se avaliar o fluxo por macroporos na zona não saturada.

Os dados obtidos referentes ao fluxo de água na zona não saturada indicaram que existem dois padrões de fluxo, um que ocorre durante períodos de baixa pluviosidade e outro que ocorre durante os período de alta pluviosidade. 
O primeiro padrão de fluxo caracteriza-se pelos baixos valores de fluxo de água, que pode ser descendente ou ascendente. No segundo padrão de fluxo ocorrem altos valores de fluxo de água na zona não saturada, predominantemente descendente.

A área de estudo foi dividida em três (1,2 e 3) nas quais foram aplicadas diferentes taxas de vinhaça $\left(150,0\right.$ e $\left.300 \mathrm{~m}^{3} / \mathrm{ha}\right)$, que foi submetida à análises químicas. Os parâmetros utilizados nas análises químicas foram: cloreto, carbono orgânico dissolvido, sulfato, potássio, nitrogênio Kjeldahl total, nitrogênio amoniacal e nitrogênio nitrato.

Quanto a qualidade das águas das zonas não saturada e saturada, notaram-se alterações nos valores dos parâmetros analisados na zona não saturada e para alguns parâmetros na zona saturada, após a aplicação da vinhaça. As análises químicas demonstram que os parâmetros cloreto, carbono orgânico dissolvido, nitrogênio Kjeldahl total, nitrogênio amoniacal e sulfato, atingiram as águas subterrâneas causando alterações nos seus valores naturais, após a aplicação da vinhaça. Desta forma, estes parâmetros, devem ser considerados na decisão da definição de taxas agronômicas de aplicação da vinhaça, com o intuito de resguardar as características naturais das águas subterrâneas. O potássio, elemento utilizado para definir as taxas de aplicação da vinhaça, e o nitrogênio nitrato não determinaram alterações significativas na qualidade das águas da zona saturada neste estudo.

Foi constatado que os sedimentos da Formação Botucatu apresentam baixa capacidade de retenção de água na zona não saturada e possuem alta capacidade de transporte dos constituintes da vinhaça. A zona saturada apresenta altos valores de velocidade das águas subterrâneas indicando rápido espalhamento dos constituintes da vinhaça. Desta forma, esta pesquisa demonstrou que a área de afloramento da Formação Botucatu mostra-se extremamente vulnerável à mudanças nas características naturais das suas águas subterrâneas, devido à aplicação da vinhaça por fertirrigação. 


\begin{abstract}
Vinasse, the main waste produced from the alcohol and sugar industrialization, has been widely applied on sugar cane plantations as a source of nutrients, mainly potassium, in order to substitute chemical fertilizers. Many researches demonstrated that vinasse is a efficient fertilizer, however there are few researches about the behavior of vinasse's constituents through unsaturated and saturated zones.
\end{abstract}

The principal alcohol and sugar producer of Brazil is the São Paulo State which has extensive sugar cane plantations and which have been constantly submited to the to the fertirrigation process. This sugar cane plantations are located over the Botucatu and Bauru Aquifers which are the majors one in the São Paulo State.

This research was developed in a selected area located over the outcrop area of Botucatu Formation, occupied by sugar cane plantation, This study was developed in order to verify the behavior of vinasse's constituents through unsaturated and saturated zones and to evaluate the monitoring methods of unsaturated and saturated zones utilized, in the area submited to the fertirrigation.

The selected study area was submited to a geologic and hydrogeologic characterization, using soil and sediments cores colected in boreholes made with manual auger, in order to determine the mineralogical and granulometric constitution of unsaturated and saturated zones. Indisturbed cores were colected in trenches in order to make water retention curves in the unsaturated zone.

Monitoring wells were installed to determine water levels and flow directions variations. These data were utilized to locate monitoring equipments and vinasse aplication areas. In order to collect hydraulic potential measurements and ground-water samples, for punctual chemical analyses, multilevel monitoring wells were installed.

Tensiometers were installed in order to determine water flux pattern of the unsaturated zone, as well as suction lysimeters to collect water samples to chemical analyses. Panlysimeters were installed in order to evaluate the macropores water flux.

The unsaturated zone water flux data indicated that there are two flux patterns. One which occurs during low rain periods, and another one which occurs during high rain periods.

The first flux pattern shows low water flux values, which may be ascendent or descendent. The second flux pattern shows high water flux values, predominantly descendent. 
The study area was subdivided in three areas (1,2 and 3) where different rates of vinasse were applied $\left(150,0\right.$ e $\left.330 \mathrm{~m}^{3} / \mathrm{ha}\right)$. The vinasse was submited to chemical analysis. The parameters used in all chemical analysis were: chloride, dissolved organic carbon (DOC), sulphate, potassium, total Kjeldah! nitrogen (TKN), ammoniacal nitrogen and nitrate nitrogen.

The water quality of unsaturated and saturated zones were altered. The chemical analysis, after the application of vinasse, showed that the parameters DOC, chloride, TKN, ammoniacal nitrogen and sulphate reached concentrations that were above the ground water natural values. In this way, these parameters should be considered in the definition of vinasse application rates. Actualy to define application rates of vinasse the parameter utilized is the potassium, which in this research did not determine, as well as nitrate nitrogen, changes on the ground water quality.

The sediments of the Botucatu Formation showed low water retention capacity in the unsaturated zone and high vinasse's constituents transport capacity. The saturated zone showed high ground water velocity values indicating high vinasse's constituents transport. This research demonstrated that, the outcrop area of the Botucatu Formation is very vulnerable to changes on ground water quality characteristics that can be promoted by vinasse application by fertirrigation. 


\section{1- INTRODUÇÃo}

A vinhaça tem sido amplamente utilizada como uma fonte de nutrientes para as plantações de cana-de-açúcar, através do processo denominado fertirrigação, que é realizado utilizando-se principalmente caminhões e aspersores.

Vários autores destacam os efeitos benéficos da aplicação da vinhaça sobre a produtividade da cana-de-açúcar, entretanto, as pesquisas sobre os efeitos da aplicação da vinhaça na qualidade dos solos e das águas subterrâneas são ainda em número reduzido.

As plantações de cana-de-açúcar no Estado de São Paulo concentram-se sobre importantes aqüíferos, como o Aqüífero Bauru, e sobre a área de afloramento das Formações Pirambóia e Botucatu, que se constitui na área de recarga regional, e na parte mais vulnerável à poluição do Sistema Aqüífero Botucatu. Desta forma, pesquisas devem ser desenvolvidas com o objetivo de proteger a qualidade das águas subterrâneas das diversas formas de disposição da vinhaça no solo, como por exemplo canais de transporte de vinhaça, infiltração em áreas de sacrifício e a fertirrigação.

Este estudo visa principalmente verificar o comportamento dos constituintes da vinhaça nas zonas não saturada e saturada em área de afloramento da Formação Botucatu submetida à fertirrigação com vinhaça.

\section{2- OBJETIVOS}

Os principais objetivos deste estudo foram:

- Estudar o comportamento dos constituintes da vinhaça aplicada através da técnica denominada fertirrigação, nas zonas não saturada e saturada, com o intuito de verificar os efeitos desta prática sobre a qualidade das águas subterrâneas na área de afloramento da Formação Botucatu, área estratégica para a proteção do principal sistema aqüifero do Estado de São Paulo.

- Avaliar a eficiência dos métodos de monitoramento das zonas não saturada e saturada utilizados no estudo.

- definir as características hidrogeológicas da área de estudo visando levantar subsídios para definição de taxas e períodos de aplicação mais favoráveis de vinhaça objetivando proteger a qualidade das águas subterrâneas. 


\section{3- REVISÃO BIBLIOGRÁFICA}

\section{1- A vinhaça}

\subsection{1- Histórico indústria sucro-alcooleira no Brasil}

A cana-de-açúcar, Saccharum officinarum, é uma gramínea originária da Índia que chegou ao Brasil em torno de 1530. A agroindústria da cana-de-açúcar no Brasil teve início pouco antes da invasão holandesa, em 1630, na Região Nordeste. A partir daí, houve o desenvolvimento do cultivo da cana-de-açúcar em toda a costa brasileira, estimulado por um clima favorável e solos de boa qualidade.

Em 1931, passou a vigorar o Decreto n 19.717 que regulamentou a mistura de $5 \%$ de álcool à gasolina, dando um pequeno impulso ao processo de industrialização da cana-de-açúcar.

Em 1933 foi criado o Instituto do Açúcar e Álcool (IAA), com a finalidade de manter o equilíbrio interno entre as safras anuais de cana, o consumo de açúcar e uma produção definida de álcool.

O álcool foi considerado tradicionalmente no Brasil um subproduto do açúcar. A partir da década de 1970, com a crise do petróleo, passou a desempenhar um papel estratégico na economia brasileira.

Em 1975, a indústria alcooleira teve seu grande impulso, com a institucionalização do PROÁlCOOL - Programa Nacional do Álcool, através do Decreto $n^{\circ} 76.593$, de 14/11/75, que visava atender as necessidades dos mercados interno e externo e à produção de combustível automotivo, principalmente. Desde então, houve um crescente aumento da produção de álcool, conforme pode ser observado na tabela 3.1 (HESPANHOL, 1979).

A matéria prima para a fabricação de álcool é o caldo misto, resultante da moagem da cana, embora possam ser utilizados o caldo clarificado, que já passou pelo processo de purificação ou até mesmo o xarope, obtido em uma etapa da produção de açúcar. $\mathrm{O}$ caldo misto forma o mosto, que é levado para as dornas de fermentação juntamente com uma mistura de leite de levedura, água e ácido sulfúrico. As dornas são grandes tanques cilindricos, com um sistema de serpentinas metálicas que mantém a temperatura em torno de 30 a $32^{\circ} \mathrm{C}$. Na fermentação obtém-se o vinho, que vai para centrífugas para separar as leveduras, e em seguida este é bombeado para colunas de destilação, onde é aquecido até $90^{\circ} \mathrm{C}$ e transformado em álcool bruto. Este segue para colunas onde são obtidos o álcool hidratado ou anidro (COPERSUCAR, 1989). 
Tabela 3.1 - Evolução da produção de álcool no Brasil*

\begin{tabular}{|c|c|}
\hline Safra / Ano & $\begin{array}{c}\text { Produção de álcool } \\
\left(10^{9} \text { litros }\right)\end{array}$ \\
\hline $75 / 76$ & 0,6 \\
\hline $76 / 77$ & 0,7 \\
\hline $77 / 78$ & 1,5 \\
\hline $78 / 79$ & 2,5 \\
\hline $79 / 80$ & 3,4 \\
\hline $80 / 81$ & 3,7 \\
\hline $81 / 82$ & 4,2 \\
\hline $82 / 83$ & 5,8 \\
\hline $83 / 84$ & 7,9 \\
\hline $84 / 85$ & 9,2 \\
\hline $85 / 86$ & 11,8 \\
\hline $86 / 87$ & 10,5 \\
\hline $87 / 88$ & 11,5 \\
\hline $88 / 89$ & 11,7 \\
\hline $89 / 90$ & 10,7 \\
\hline $90 / 91$ & 11,5 \\
\hline $91 / 92$ & 12,7 \\
\hline $92 / 93$ & 11,7 \\
\hline
\end{tabular}

*CARVALHO, L.C.C. (Associaçāo das Indústrias de Açúcar e de Álcool do Estado de São Paulo, São Paulo,SP) Comunicação pessoal, 1994

\subsection{2- Composição da vinhaça}

Entre os resíduos produzidos nesse processo industrial, a vinhaça, restilo ou vinhoto, que é produzido na base da coluna de destilação do álcool, é o que tem causado maiores controvérsias em relação ao seu tratamento, utilização ou disposição final, sendo gerados de 10 a 14 litros de vinhaça por cada litro de álcool produzido, além de possuir altos valores de DBO (Demanda Bioquímica de Oxigênio) (HESPANHOL, 1979).

A vinhaça tem coloração verde castanha, turbidez elevada, elevada concentração de sólidos sedimentáveis e sua composição varia de acordo com a natureza do mosto utilizado na produção do álcool (mosto de melaço, mosto misto e mosto de caldo), natureza e composição da cana-deaçúcar, com o processo de fermentação e com o tipo de operação do aparelho destilatório (CALDAS, 1960 in CASARINI, 1989). A tabela 3.2 mostra a composição da vinhaça de acordo com o tipo de mosto. 
Tabela 3.2 - Composição química da vinhaça (Hassuda, 1989)

\begin{tabular}{|c|c|c|c|}
\hline $\begin{array}{c}\text { Parâmetros } \\
\text { (mg/l)/tipo de } \\
\text { vinhaça }\end{array}$ & $\begin{array}{c}\text { mosto de } \\
\text { melaço }\end{array}$ & mosto misto & mosto de caldo \\
\hline Mat. org. & $49.070,0$ & $31.210,0$ & $24.387,0$ \\
\hline Nitr.total & 665,0 & 400,0 & 285,0 \\
\hline Fósforo & 200,0 & 270,0 & 220,0 \\
\hline Potássio & $5.530,0$ & $2.680,0$ & $1.525,0$ \\
\hline Cálcio & $2.152,0$ & $1.050,0$ & 405,0 \\
\hline Magnésio & 106,0 & 426,0 & 312,0 \\
\hline Sulfato & $1.050,0$ & $1.600,0$ & $2.030,0$ \\
\hline Ferro & 80,0 & 78,0 & 69,0 \\
\hline Cobre & 5,0 & 21,0 & 7,0 \\
\hline Zinco & 3,0 & 19,0 & 2,0 \\
\hline Manganês & 7,0 & 6,0 & 7,0 \\
\hline pH & 4,2 & 3,9 & 3,6 \\
\hline
\end{tabular}

\subsection{3- Potencial poluidor e disposição final da vinhaça}

Em 1985/1986, por exemplo, foram produzidos aproximadamente $11,8 \times 10^{6} \mathrm{~m}^{3}$ de álcool no Brasil, gerando aproximadamente $144 \times 10^{6} \mathrm{~m}^{3}$ de vinhaça. Admitindo-se a geração de 12 litros de efluente por litro de álcool produzido, DBO do efluente igual a $20 \mathrm{~g} / \mathrm{l}$, duração da safra de 150 dias e demanda equivalente de $54 \mathrm{~g} \mathrm{DBO}$ /habitante-dia, a carga poluidora, oriunda da vinhaça das indústrias alcooleiras em 1986, correspondeu a um população de 329 milhões de habitantes, equivalente, portanto, a 2,5 vezes a carga gerada pela população nacional naquele ano. Este quadro agrava-se ainda mais no Estado de São Paulo, principal produtor nacional, cuja produção na safra $86 / 87$ atingiu a marca de $6.190,3$ milhões de $\mathrm{m}^{3}$ de álcool, que correspondeu a 58,92\% da produção nacional, gerando uma carga poluidora corresponde aproximadamente a 6 vezes a carga gerada pela população do Estado (HASSUDA et al., 1990).

Estes valores podem ser considerados constantes, a partir da safra $85 / 86$, pois a produção anual de álcool apresentou valores sempre próximos a $11,0 \times 10^{6} \mathrm{~m}^{3}$.

A vinhaça era lançada, inicialmente, nos cursos d'água superficiais causando problemas como a morte de peixes. Em 1978 a portaria MINTER $n^{\circ} 158$, de 03/11/78, passou a proibir o lançamento desses efluentes em mananciais superficiais. Desde então, passou-se a descartar a 
vinhaça em "áreas de sacrificio", onde ela era infiltrada maciçamente em grandes volumes no solo através de tanques e sulcos de infiltração.

Os trabalhos realizados pelos pesquisadores da área agronômica revelaram a possibilidade do aproveitamento da vinhaça como fertilizante para a cultura de cana-de-açúcar devido à sua alta concentração de e potássio.

A partir disso a prática da fertirrigação da cana-de-açúcar com vinhaça passou a ser feita conjuntamente com o descarte da vinhaça por infiltração em "áreas de sacrificio". A fertirrigação passou a ser praticada em áreas onde os custos de transporte da vinhaça eram menores que os custos da infiltração tradicional. Atualmente a vinhaça é infiltrada por fertirrigação a uma taxa de aplicação de até $350 \mathrm{~kg} \mathrm{~K} 2 \mathrm{O} /$ hectare (HASSUDA et al. 1992).

A infiltração de vinhaça em áreas de sacrificio no Estado de São Paulo foi proibida pela CETESB (Cia. de Tecnologia e Saneamento Ambiental), após a constatação de que esta prática é nociva à qualidade das águas subterrâneas.

A vinhaça, é fonte geradora de impacto ambiental. Entre os vários tipos de recursos naturais que podem ser contaminados por este resíduo destacam-se os solos e as águas subterrâneas (HASSUDA et al., 1992).

Conforme pode se observar, pelo processo de evolução da indústria canavieira, nunca houve a preocupação, a nível nacional, com a proteção do solo e das águas subterrâneas contra a poluição, por esse tipo de atividade industrial. Entretanto, no Estado de São Paulo, vigora atualmente a Lei $\mathrm{n}^{\circ} 6134$, de $02 / 06 / 88$, cujo artigo $5^{\circ}$, determina que os resíduos líquidos, sólidos ou gasosos, provenientes de atividades agropecuárias, industriais, comerciais ou de qualquer outra natureza, só poderão ser conduzidos ou lançados de forma a não poluírem as águas subterrâneas (HASSUDA, 1989).

Desta forma pesquisas devem ser desenvolvidas visando avaliar o comprometimento da qualidade das águas subterrâneas em áreas de disposição de vinhaça no solo.

Segundo HASSUDA (1989) cerca de 97\% das usinas e destilarias do Estado de São Paulo encontram-se sobre três domínios geológicos, que constituem os principais sistemas aqüíferos do Estado de São Paulo: 43\% sobre o domínio do Grupo Bauru, 25\% sobre o domínio da Formação Serra Geral e $29 \%$ sobre a Formação Botucatu. 


\subsection{4- Estudos na área de poluição dos solos e das águas subterrâneas}

Ainda são escassas as pesquisas verificando a mobilidade dos constituintes da vinhaça nos solos e, principalmente, seu efeito sobre a qualidade das águas subterrâneas.

Alguns dos experimentos realizados, desde meados de 1985 até hoje, com o objetivo de avaliar os impactos da infiltração da vinhaça sobre a qualidade das águas subterrâneas estão localizados, em sua maioria, no centro-oeste do Estado, onde está concentrada a maioria das indústrias sucroalcooleiras paulistas, com solos com diferentes características físico-químicas. Os resultados obtidos nos experimentos têm sido utilizados como subsídios para a elaboração de normas de disposição, construção de canais de transporte e tanques de armazenamento de vinhaça no Estado de São Paulo (HASSUDA et al., 1992).

Neste sentido podem ser citados os trabalhos publicados por CUNHA et al. (1987), HASSUDA (1989), CASARINI (1989), HASSUDA et al. (1990), CRUZ et al. (1990), GLOEDEN et al. (1991).

CUNHA et al. (1987) apresentam os resultados de um experimento desenvolvido em área de fertirrigação com vinhaça através de canhão hidráulico, a uma taxa de $800 \mathrm{~m}^{3} / \mathrm{ha}$ correspondendo a uma aplicação de $804,64 \mathrm{~kg}$ de potássio e $395,86 \mathrm{~kg}$ de nitrogênio, com o objetivo de avaliar a dinâmica dos constituíntes da vinhaça e os riscos de poluição das águas subterrâneas em área de fertirrigação com vinhaça.

Os solos da área possuem textura areno-argilosa e geologicamente a área está sobre sedimentos da Formação Corumbataí cortados por intrusivas básicas, na região de Piracicaba. As leituras nos tensiômetros instalados foram realizadas diariamente durante seis meses e as amostras de solução do solo foram coletadas, no mesmo período, duas vezes por mes.

Os objetivos do trabalho resumiram-se na observação do comportamento do potássio e do nitrogênio na zona não saturada. Basicamente foi observado que a transferência dos íons, abaixo da profundidade de 1,2 m, por lixiviação foi muito pequena. Este fato ocorre como consequência do consumo de nitrogênio e potássio pelas plantas e adsorsão pelo solo. Entretanto, os autores citam que devem ser realizados estudos, onde ocorre aplicação de vinhaça a mais tempo e em diferentes tipos de solos e taxas de aplicação.

CASARINI (1989) apresenta os resultados de um experimento realizado em um latossolo vermelho-amarelo, textura média, localizado na região de Piracicaba, que esteve sob o cultivo da cana-de-açúcar por 10 anos, recebendo fertilizantes industrializados. Foram efetuados dois 
tratamentos onde foram aplicadas taxas de 150 e $600 \mathrm{~m}^{3} / \mathrm{ha}$ de vinhaça respectivamente através de aspersão. Amostras de solo eram retiradas das profundidades de 0 a $15 \mathrm{~cm}$ e de 15 a $30 \mathrm{~cm}$ para análises físico químicas e microbiológicas. Verificou-se que ocorreu um aumento do $\mathrm{pH} \mathrm{e}$ no teor de $\mathrm{Ca}^{2+}, \mathrm{Mg}^{2+}, \mathrm{K}^{+}$e nitrogênio total no solo. Foi verificado, também, um efeito estimulante às bactérias e fungos, uma redução na população de actinomicetos e uma inibição dos microorganismos celulolíticos aeróbios e um pequeno efeito estimulatório nos celulolíticos anaeróbios. Os efeitos da aplicação da vinhaça sobre as propriedades químicas e microbiológicas do solo foram, entretanto, contundentes e passageiros

No período de julho de 1985 a setembro de 1987 foi monitorada uma área de infiltração de vinhaça ("área de sacrifício") no Município de Novo Horizonte-SP. A zona de infiltração recebeu aproximadamente $348.000 \mathrm{~m}^{3} /$ ano de vinhaça, até a safra de 1984/1985. A vinhaça era depositada em tanques escavados nos locais de cotas mais elevadas e distribuida por gravidade pela zona de infiltração, através de sulcos ou canais.

As etapas dos trabalhos compreenderam: investigação geofísica pelo método da eletrorresistividade e eletromagnético indutivo, implantação de 20 piezômetros, medidas de nível d'água e coletas seguidas de análise físico química da vinhaça, dos sedimentos da zona não saturada e da água subterrânea (HASSUDA, 1989; HASSUDA et al., 1990).

A área localiza-se sobre sedimentos do Grupo Bauru, constituído por arenitos de granulação fina a muito fina, cor róseo a castanho, alternados com siltitos de cor castanho avermelhada.

Os resultados deste experimento demonstraram que a infiltração da vinhaça teve como maior impacto a alteração da qualidade fisico-química da água subterrânea. Na área de interesse, em condições naturais, ela apresentou-se como bicarbonatada sódica. Sob o efeito da vinhaça passou a ser cloretada potássica, evoluindo com o tempo para cloretada magnesiana e, finalmente para cloretada cálcica.

Entretanto, a maior preocupação residiu nos parâmetros que possuiam concentrações acima dos padrões de potabilidade: o nitrogênio amoniacal, encontrado com valores entre $>0.005$ e 9.8 $\mathrm{mg} / \mathrm{l}$, o magnésio, entre 12 e $210 \mathrm{mg} / \mathrm{l}$, o alumínio, entre $>0.02 \mathrm{e} 23 \mathrm{mg} / \mathrm{l}$, o ferro, entre $>0.005$ e $60 \mathrm{mg} / \mathrm{l}$, o manganês, entre 5 e $60 \mathrm{mg} / \mathrm{l}$, e o cloreto, entre 4 e $640 \mathrm{mg} / \mathrm{l}$.

CRUZ et al. (1990) em experimento realizado em áreas com diferentes períodos de aplicação com vinhaça por fertirrigação $(0,5,10$ e 15 anos) na região de Lençóis Paulista, detectaram elevação da concentração de nitrato nas águas subterrâneas. 
GLOEDEN et al. (1991), apresentando alguns resultados preliminares, indicam que em solos e sedimentos permeáveis com aplicação de vinhaça, os parâmetros cloreto, carbono orgânico, nitrogênio orgânico e amoniacal podem representar risco de contaminação das águas subterrâneas.

Entretanto, estes trabalhos indicam que existe a necessidade de estudos mais detalhados visando determinar o efeito da aplicação da vinhaça por fertirrigação no solo, em várias situações diferentes, como por exemplo, em diferentes tipos de solos, sedimentos e rochas, e com diferentes taxas e períodos de aplicação.

\section{2- As zonas não saturada e saturada}

Com o intuito de descrever as características principais das zonas não saturada e saturada foram consultadas várias fontes bibliográficas dentre as quais destacam-se os trabalhos publicados por HILLEL (1980a e b), BALLESTERO et al. (1991), FETTER (1993), USEPA (1980), USEPA (1986a) e CULLEN et al. (1992), por apresentarem os conceitos básicos e definições referentes ao fluxo de água e solutos, destacando os complexos processos que ocorrem na zona não saturada. Desta forma foram traduzidos partes destes textos para a confecção de uma revisão bibliográfica ampla e detalhada sobre o assunto. Destaca-se também o trabalho de REICHARDT (1985) em português do qual também foram extraídos algumas partes.

A região da crosta terrestre que se estende da superficie desta até a região permanentemente saturada com água é chamada de zona vadosa (BALLESTERO et al., 1991; USEPA, 1986a; CULLEN et al., 1992). Segundo BOWER (1978 in CULLEN et al., 1992), não é apropriado referir-se a esta zona através do termo zona não saturada ou referir-se a todo fluxo, que ocorre dentro desta zona, como fluxo não saturado, pois dentro da zona vadosa podem ocorrer zonas saturadas restritas e eventualmente temporárias, devido ao acúmulo de água acima de camadas com permeabilidade relativamente mais baixa, formando zonas saturadas suspensas (FETTER, 1993). Entretanto, o termo zona não saturada é frequentemente utilizado em livros especializados e na legislação de água subterrânea (USEPA, 1986a; CLEARY, 1989). BALLESTERO et al. (1991) considera os dois termos sinônimos. Outro termo normalmente utilizado para denominar esta zona é zona de aeração (USEPA, 1986a). FETTER (1988), utiliza os três termos como sinônimos e FREEZE \& CHERRY (1979) utilizam o termo zona não saturada. Segundo LEHR (1988), o termo "vadosus" significa raso e "vadere" significa andar ou passar com dificuldade, ou movimento em pequena profundidade. Entretanto, como o Latim não é mais utilizado usualmente, o termo zona não saturada causa menos confusão. 
A principal característica da zona não saturada que a distingue da zona saturada é o grau de saturação do espaço poroso. Na zona saturada, todos os poros estão cheios de água (ou outro fluído miscível com a água ou líquidos imiscíveis) e o conteúdo volumétrico de água, $\theta$, é igual a porosidade. Em contraste, os fluídos que ocupam os espaços vazios ou porosos da zona não saturada, podem ser líquidos (água e as vezes líquidos imiscíveis com água) e gases (ar, vapor d'água) (FREEZE \& CHERRY, 1979; BEAR, 1966; CLEARY, 1989). A proporção relativa de ar e água nos poros pode variar e alternando com isto as propriedades hidráulicas do meio poroso (FETTER, 1993).

\subsection{1 - A fase sólida}

"A fase sólida é caracterizada por uma estrutura, formada por materiais sólidos e espaços vazios, através da qual os fluídos podem movimentar-se ou ficarem retidos. Os materiais sólidos podem ser partículas inertes da rocha fraturada, seixos, cascalho, areias, siltes e argilas, assim como matéria orgânica, isto é, solo, sedimentos e/ou rochas. Partículas sólidas pequenas, que são transportadas pelos fluídos e microorganismos fixos e flutuantes podem ser incluídos na fase sólida. Parâmetros físicos são utilizados para descrever os sólidos inertes da fase sólida, como por exemplo, a distribuição granulométrica, porosidade, angularidade, superficie específica, e uniformidade. A matéria orgânica é tipicamente separada dos sólidos inertes, e é apenas identificada como uma porcentagem do volume total. Muitos destes parâmetros são também relacionados com as características conteúdo e mobilidade das fases fluídas" (BALLESTERO et al., 1991).

A fase sólida pode ser caracterizada através da aplicação de técnicas, normalmente utilizadas em pedologia, física do solo, sedimentologia, geologia estrutural e petrologia, para determinação de parâmetros, que quantificam as propriedades físicas descritas.

A porosidade da fase sólida é a relação em porcentagem do volume de espaços não ocupados por material sólido pelo volume total do material (FETTER, 1988). "Estes espaços são conhecidos como poros, interstícios, espaços porosos ou vazios. Os interstícios originais ou primários foram formados por processos geológicos durante a gênese da rocha e podem ser encontrados principalmente em rochas sedimentares e igneas, além dos solos. Os interstícios secundários desenvolveram-se após a formação das rochas, incluindo como exemplo juntas, fraturas, aberturas por dissolução e aberturas formadas por plantas e animais.

Com relação à dimensão, os poros podem ser classificados como capilares, supercapilares e subcapilares. Os poros capilares são suficientemente pequenos para que as forças de tensão superficial retenham a água dentro dos poros, enquanto que os poros supercapilares são maiores 
que os capilares e os subcapilares são tão pequenos que a água é segura por forças principalmente de adesão. Dependendo da conexão dos poros entre si, estes podem ser classificados em comunicantes ou isolados" (TOOD, 1959).

Algumas litologias, como arenitos fraturados e folhelhos, apresentam os dois tipos de porosidade (CLEARY, 1989).

Um meio poroso não saturado pode ser idealizado como uma rede de tubos capilares, de vários tamanhos, dispostos aleatoriamente. O grau de saturação do líquido varia, dependendo das propriedades físicas da fase sólida e do padrão de entradas e saídas de água.

\subsection{2- Distribuição de fluídos nas zonas não saturada e saturada}

"Uma molécula de água pode permanecer na zona não saturada de minutos a séculos, dependendo das características ligadas ao transporte de água nesta zona. Os mecanismos pelos quais a água pode entrar na zona não saturada são: precipitação e recarga (chuva, irrigação, etc), além do fluxo de água proveniente da zona saturada, ou ainda, reações biológicas e químicas. A água pode também sair da zona não saturada através da evapotranspiração, drenagem para a zona saturada e também por reações biológicas e químicas" (BALLESTERO et al., 1991).

DAVIS \& DE WIEST (1966 in USEPA, 1986a) subdividiram a zona não saturada em três regiões: zona do solo, zona intermediária e franja capilar.

A zona do solo é formada por material de alteração das rochas e matéria orgânica. O movimento da água nesta zona ocorre principalmente por infiltração, percolação, redistribuição e evaporação da água (KLUTE, 1965 in USEPA, 1986a).

A zona intermediária é constituída por material não alterado. Em alguns casos esta região pode não existir, quando, por exemplo, a zona do solo está em contato direto com o embasamento (sem fraturas). Entretanto ela pode chegar a possuir grandes espessuras, por exemplo em ambientes sedimentares e em rochas fraturadas (USEPA, 1986a).

"A franja capilar separa a zona não saturada da saturada. Quanto mais no extremo inferior da classificação granulométrica (fração fina) concentrar-se a distribuição do tamanho dos grãos, maior será a altura atingida acima do lençol freático, devido aos efeitos da sucção capilar" (CLEARY, 1989). 
A franja capilar pode ser saturada e ainda assim exibir pressão negativa. Por esta razão alguns autores a consideram como uma parte da zona saturada (CLEARY, 1989). Entretanto, vários autores, como BEAR (1966), USEPA (1986a) e BALLESTERO et al. (1991) incluem a zona capilar como parte da zona não saturada.

FREEZE \& CHERRY (1979) citam que a franja capilar não se enquadra nas zonas não saturada e saturada e definiram o termo zona de tensão de saturação, considerado por eles mais adequado para denominar esta zona.

O número de estudos sobre o movimento da água e solutos na zona do solo é infinitamente superior aos estudos efetuados nas outras zonas acima citadas (USEPA, 1986a).

Segundo FETTER (1993), historicamente, os cientistas do solo desenvolveram vários estudos na zona não saturada, pois estavam interessados em investigar a passagem de água e solutos nesta zona para as raízes das plantas. Mais recentemente estes cientistas passaram a estudar também o comportamento de contaminantes na zona não saturada. Com o desenvolvimento da Ciência "Hidrogeologia Aplicada" à Contaminação, os hidrogeólogos também tornaram-se muito mais interessados em estudar os fenômenos da zona não saturada, pois grande número de problemas ocasionados pela maioria dos contaminantes têm inicio ou ocorrem nesta zona.

"A expressão água subterrânea denomina a água localizada abaixo da superfície do terreno contida nos poros interconectados, na zona saturada, sob pressão hidrostática. Este fato leva a uma separação artificial entre a água localizada acima e abaixo do lençol freático. $\mathrm{Na}$ verdade, toda a água subsuperficial é conectada hidráulicamente através de filmes intergranulares. A água flui para o lençol freático em resposta aos gradientes de potencial gravitacional e de pressão. Desta forma, para evitar noções falsas sobre os processos de fluxo na zona não saturada seria preferível utilizar o termo água subterrânea para toda a água localizada em subsuperficie. Entretanto o termo água subsuperficial, como é utilizado por DRISCOLL (1986), é usualmente utilizado na literatura especializada. Portanto, deve-se destacar que, nesta classificação, as águas subterrâneas, da zona saturada, são a maior divisão das águas subsuperficiais, que inclue, em outra categoria, a água da zona não saturada, conectada hidraulicamente" (CULLEN et al., 1992).

\subsection{3- Energia da água nas zonas não saturada e saturada}

Segundo HILLEL (1980a) a água do solo (termo utilizado em Física do Solo para descrever a água presente em subsuperficie, em inglês "soil water" ou "soil moisture"), pode conter energia em diferentes formas e quantidades. 
De acordo com REICHARDT (1985) "a Física Clássica reconhece duas formas principais de energia: a cinética e a potencial. Uma vez que o movimento da água no solo é lento, sua energia cinética é muito pequena. Entretanto, a energia potencial, que é relacionada à posição ou condição interna da água, é de primeira importância na determinação do estado de energia da água do solo. Este estado de energia é descrito pela função termodinâmica energia livre de Gibs, que recebe o nome particular de potencial total da água. Diferenças de potencial total da água em diferentes ponto dão origem a seu movimento".

Segundo HILLEL (1980a) "a água do solo move-se na direção de decréscimo da energia potencial. Não é a quantidade absoluta de energia potencial da água do solo que é importante, mas sim o nível relativo de energia em regiões diferentes na zona não saturada. $O$ conceito de potencial da água do solo expressa a energia potencial da água do solo em relação ao estado energético da água livre sob pressão atmosférica, localizada em um reservatório hipotético, com a mesma temperatura e elevação da água do solo. Portanto, pode-se determinar a magnitude relativa da energia potencial da água em posições e tempos diferentes".

REICHARDT (1985) cita que "a taxa de decréscimo de potencial ao longo de uma direção é uma medida de força responsável pelo movimento. Assim, o conhecimento de seu estado de energia em cada ponto dentro do sistema pode permitir o cálculo das forças que atuam sobre a água, isto é, determinar quanto afastada ela se acha do estado de equilíbrio e determinar sua tendência de movimento. Consequentemente, a força que age sobre a água do solo, direcionada de uma zona de alto para uma zona de baixo potencial, é resultante do gradiente de potencial, que é a variação da energia potencial com a distância".

"Na zona saturada a água está sob pressão hidrostática maior que a pressão atmosférica. Portanto o nível da energia potencial desta água deve ser maior que a água livre do reservatório referencial, podendo ser considerado positivo. Desta forma, ocorre movimento da água da zona saturada para o reservatório.

Na zona não saturada, a água é fixada à fase sólida por forças capilares e de adsorção, portanto, sua energia potencial é negativa, uma vez que sua pressão hidrostática é menor que a pressão do reservatório referencial. Desta forma, a tendência espontânea será da matriz sólida extrair água do reservatório. Além das forças resultantes da atração da matriz sólida, a água da zona não saturada é submetida a forças originadas pela presença de solutos e à ação da gravidade.

O potencial total da água da zona não saturada e saturada pode, portanto, ser definido como a soma de várias contribuições como: o potencial gravitacional, potencial de pressão, potencial osmótico e outros possíveis" (HILLEL, 1980a). 
Segundo HILLEL (1980a) "o potencial gravitacional da água do solo, em um ponto, é determinado pela elevação deste em relação a um referencial arbitrário. A uma altura $\mathrm{z}$ acima do referencial, a energia potencial gravitacional, $\mathrm{E}_{\mathrm{g}}$ de uma massa, $\mathrm{M}$, de água, ocupando um volume, V, é:

$\mathrm{E}_{\mathrm{g}}=\mathrm{Mgz}=\rho_{\mathrm{W}} \mathrm{Vgz}$

onde $\rho_{\mathrm{W}}$ é a densidade da água e $\mathrm{g}$ é a aceleração da gravidade. Desta forma, o potencial gravitacional em termos de energia potencial por unidade de massa é:

$\Phi_{\mathrm{g}}=\mathrm{gz}$

e em termos de energia, por unidade de volume é:

$\Phi_{\mathrm{g}, \mathrm{v}}=\rho_{\mathrm{W}} \mathrm{gz}$

Em geral, em solos saturados ou próximos da saturação, a componente gravitacional é a componente de maior importância na composição do potencial total. Quando um solo perde água gradualmente, a componente matricial passa a ter maior importância que a gravitacional (REICHARDT, 1985).

De acordo com HILLEL (1980a), "o potencial de pressão positivo, que ocorre na zona saturada, ou a pressão hidrostática, $\mathrm{P}$, da água em um ponto abaixo do lençol freático, com referência à pressão atmosférica, é:

$P=\rho g h$

Onde $\mathrm{h}$ é a profundidade do ponto abaixo da superfície livre saturada com água. A energia potencial neste ponto é:

$\mathrm{E}=\mathrm{PdV}$

e, portanto, a energia potencial por unidade de volume, é igual a pressão, $P$ :

$\Phi_{\mathrm{ps}}=\mathrm{P}$

"O potencial de pressão negativo tem sido frequentemente chamado de potencial capilar e mais recentemente potencial matricial. Este potencial da água do solo, na zona não saturada, resulta de 
forças capilares e de adsorção. Estas forças atraem e fixam a água no solo, diminuindo sua energia potencial em relação à água livre" (REICHARDT, 1985).

"A capilaridade resulta da tensão superficial da água e seu ângulo de contato com as partículas sólidas. Em adição ao fenômeno da capilaridade existe também a adsorção, que forma filmes de água sobre as superfícies das partículas" (HILLEL, 1980a).

Conforme cita HILLEL (1980a) "o potencial de pressão negativa resulta do efeito combinado dos dois mecanismos, uma vez que as bordas capilares estão em um estado de equílibrio com os filmes de adsorção. Desta forma o antigo termo potencial capilar não é adequado sendo melhor o termo potencial matricial, uma vez que ele expressa o efeito total resultante da afinidade da água pela matriz sólida".

"Os físicos do solo preferem separar o potencial de pressão positivo do potencial matricial, assumindo que os dois não podem ocorrer simultâneamente. Entretanto há uma vantagem em juntar estes potenciais em um conceito unificado (potencial de pressão), que permite considerar o perfil total, em termos de um potencial contínuo, extendendo-se nas zonas não saturada e saturada" (HILLEL, 1980a).

Segundo HILLEL (1980a), "a presença de solutos na água do solo afeta suas propriedades hidrodinâmicas e diminue sua energia potencial. As moléculas de água de uma solução tendem a migrar de uma zona com alta concentração para uma de baixa concentração de solutos. Esta migração de espécies moleculares em resposta a diferenças espaciais de concentração é chamada difusão. Se uma barreira física é colocada entre as duas regiões, atravessando o caminho da difusão, sendo a barreira permeável às moléculas do solvente, mas não às do soluto, o solvente irá passar através da barreira em um processo denominado osmose, tendendo a um estado de uniformidade na composição.

Frequentemente as moléculas do soluto são impedidas de penetrar na complexa rede de poros, que funciona como uma membrana, permitindo a adsorção preferencial das moléculas do solvente. Em soluções diluídas, a pressão osmótica, $\Pi$, é proporcional a concentração molar $M$ da solução e a temperatura $\mathrm{T}$ na seguinte forma :

$\Pi=\mathrm{MRT}$

O potencial total da água do solo pode ser expresso fisicamente de três maneiras: energia por unidade de massa $\left(\mathrm{L}^{2} \mathrm{~T}^{-2}\right)$, utilizando-se frequentemente as unidades ergs por grama ou Joules por quilograma; energia por unidade de volume $\left(\mathrm{ML}^{-1} \mathrm{~T}^{-2}\right)$, expressando o potencial total em 
dimensões de pressão, podendo ser expressa em dinas por centímetro quadrado, newtons por metro quadrado, bar ou atmosfera; energia por unidade de massa, expressa em termos de altura de água equivalente, que é o método mais simples e conveniente que os anteriores.

Portanto é comum caracterizar o estado da água do solo em termos de elevação do potencial hidráulico $(\mathrm{H})$, que é a soma do potencial gravitacional $\left(\mathrm{H}_{\mathrm{g}}\right)$ e do potencial de pressão $\left(\mathrm{H}_{\mathrm{p}}\right)$ (considerando o potencial osmótico despresível), que são expressos normalmente em centímetros de água. Desta forma em lugar de:

$\Phi=\Phi_{\mathrm{g}}+\Phi_{\mathrm{p}}$

pode-se escrever:

$\mathrm{H}=\mathrm{H}_{\mathrm{g}}+\mathrm{H}_{\mathrm{p}}$

Utilizando-se $\Phi$ para designar o potencial em termos de energia por massa, $\mathrm{P}$ em termos de pressão e H em termos de elevação, então:

$$
\begin{aligned}
& \Phi=\frac{P}{\rho_{W}} \\
& \mathrm{e} \\
& H=\frac{P}{\rho_{W} g}=\frac{\Phi}{g}
\end{aligned}
$$

\subsection{4- Curva de retenção solo-água}

O potencial matricial é função do conteúdo volumétrico de água dos poros da zona não saturada. Esta função é medida experimentalmente e é representada graficamente por uma curva conhecida como curva de retenção da água ou solução do solo ou curva característica da umidade do solo (CHILDS, 1940 in HILLEL, 1980a), ou ainda curva de retenção solo-água (FETTER, 1993).

"Quando o solo está saturado, seu conteúdo de água é igual à porosidade total, $\theta$ s. Aumentandose gradualmente o potencial matricial, este irá tornar-se cada vez mais negativo até a água do solo começar a drenar. A pressão matricial deste ponto da curva característica é chamada de pressão de borbulhamento ou valor da pressão de entrada de ar" (REICHARDT, 1985), marcado por $h_{b}$ na figura 3.1 . 


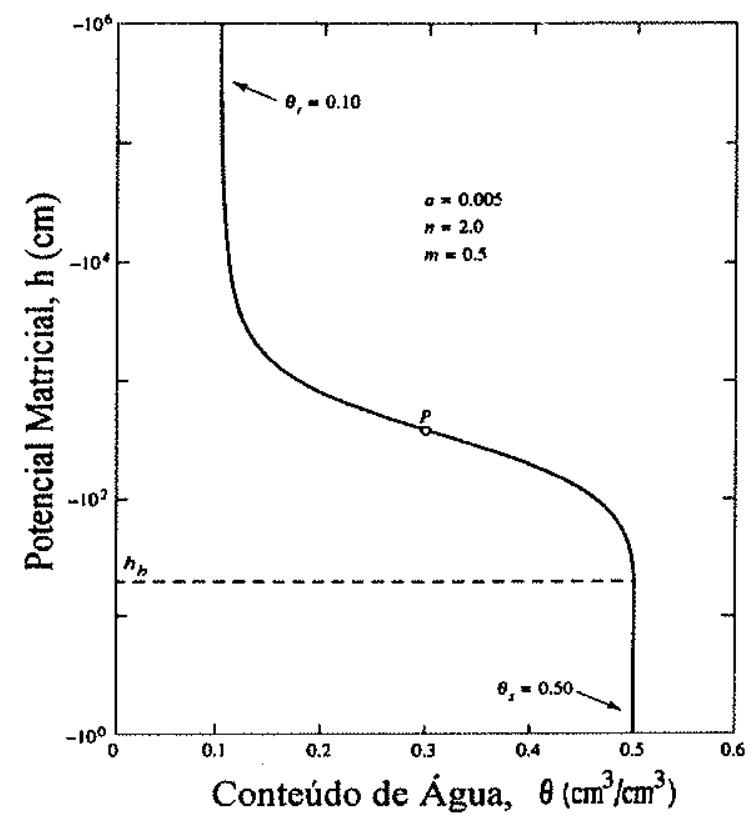

Figura 3.1 - Curva de retenção do solo-água (FETTER, 1993)

"Diminuindo-se continuamente a pressão matricial o conteúdo de água irá diminuir até atingir um valor mínimo, $\theta_{\mathrm{r}}$ " (FETTER, 1993)."O formato da curva característica é fortemente influenciado pela textura da matriz. Quanto maior o conteúdo de argila, maior a retenção de água, para qualquer valor da suç̧ão. Em uma matriz argilosa a distribuição do tamanho dos poros é uniforme, causando aumento ou diminuição gradual da sucção matricial, com a variação do conteúdo de água. Em uma matriz arenosa, a maioria dos poros são grandes, relativamente, $\mathrm{e}$ estes são rapidamente esvaziados a um dado valor de sucção, restando pequena quantidade de água, ocasionando aumento da inclinação da curva, para valores altos de sucção e diminuição da inclinação, para os valores baixos de sucção (figura 3.2)" (HILLEL, 1980a).

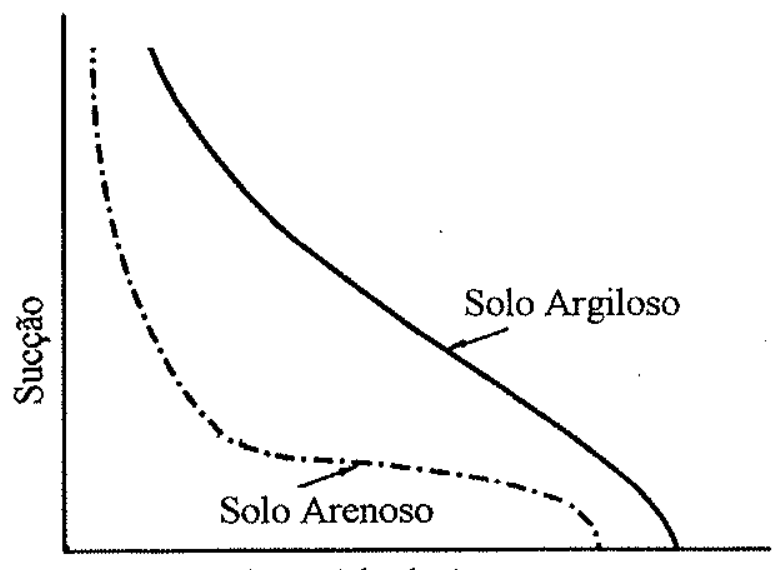

Conteúdo de água

Figura 3.2 - Curva de retenção para solos arenoso e argiloso (HILLEL, 1980a) 
"A estrutura da matriz também afeta o formato da curva caracterítica, principalmente no intervalo de baixa sucção, como pode ser visualizado pelo efeito da compactação. Com o decréscimo do volume de poros grandes, diminui o conteúdo de saturação da água e o conteúdo de água sob baixa sucção. Por outro lado, o volume de poros com tamanho intermediário aumenta com a compactação, aumentando o conteúdo de água sob sucção intermediária. Os poros pequenos, ou microporos permanecem inalterados, não alterando o formato da curva no intervalo de alta sucção (Figura 3.3).

O conteúdo de água retida sob valores baixos de sucção matricial (entre 0 e 1 bar) depende principalmente do efeito da capilaridade e da distribuição dos poros, sendo, portanto, fortemente afetado pela estrutura do solo. Em um intervalo de alta sucção capilar, a água é retida principalmente por adsorção, sendo menos influenciada pela estrutura e mais pela textura e superfície especifica da matriz" (HILLEL, 1980a).

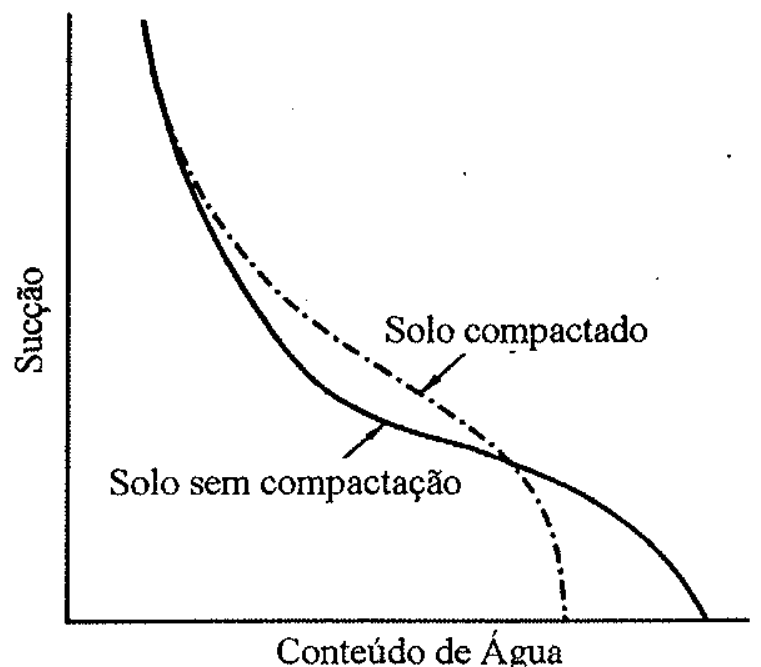

Figura 3.3 - Efeito da compactação do solo na curva de retenção (HILLEL, 1980a)

"A curva característica pode ser obtida de duas maneiras: por secamento, tomando-se inicialmente uma amostra saturada, sobre a qual é aplicada suç̧ão, para gradualmente secar a amostra, enquanto sucessivas medidas de umidade e suç̧ão são realizadas e por molhamento gradual de uma amostra, inicialmente seca, com a redução da suç̧ão. Os dois métodos geram curvas contínuas, mas não idênticas. A umidade, em equilíbrio, a uma dada suç̧ão, é maior durante o secamento do que durante o molhamento. Esta dependência dos valores de umidade e de sucção pela direção do processo é conhecida como o efeito da histerese.

O efeito da histerese pode ser atribuído a: 
- a não uniformidade dos tamanhos dos poros, resultando no efeito "ink bottle" (garrata de tinta), onde a sucção é maior durante o secamento do que durante o molhamento, pois o ângulo de contato é maior e consequentemente o raio de curvatura do menisco é maior em um menisco avançando do que em um recuando;

- o ar aprisionado reduz o conteúdo de água; e à dilatação e contração da matriz.

O efeito "ink bottle" é considerado o mais importante. Considerando um poro hipotético (figura 3.4 ), constituído de um espaço vazio grande de raio $R$, cercado por espaços estreitos de raio $r$. Se inicialmente saturado, este poro irá drenar abruptamente no momento que a sucção exceder $\psi \mathrm{r}$, onde:

$\psi_{\mathrm{r}}=2 \frac{\gamma}{\mathrm{r}}$

Para este poro ser preenchido a sucção deve decrescer abaixo de $\psi \mathrm{R}$, onde:

$\psi \mathrm{R}=2 \frac{\gamma}{\mathrm{R}}$

Uma vez que $R>r$ então $\psi r>\psi R$. A desorção depende do diâmetro dos poros estreitos, enquanto que a sorção depende do diâmetro máximo dos poros grandes. $O$ efeito da histerese é mais pronunciado em solos com granulometria grossa.

(a)

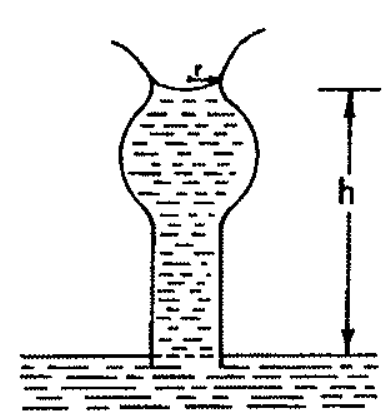

(b)

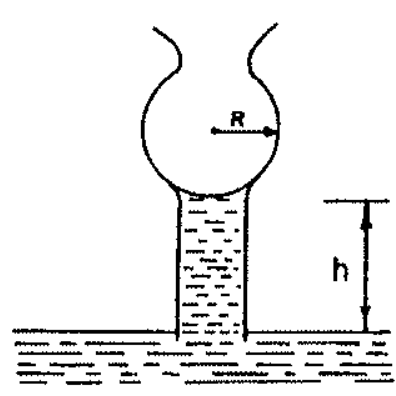

Figura 3.4 - Efeito "Ink Bottle" (HILLEL, 1980a)

As duas curvas características (molhamento e secamento) são chamadas de ramos principais. Quando um solo parcialmente úmido começa a drenar, ou quando o solo parcialmente seco é umedecido, a relação da sucção com a umidade segue curvas intermediárias. Estas curvas são chamadas de "scanning curves". 
Mudanças cíclicas podem formar "loops" entre as curvas ou ramos principais (figura 3.5)" (HILLEL, 1980a).

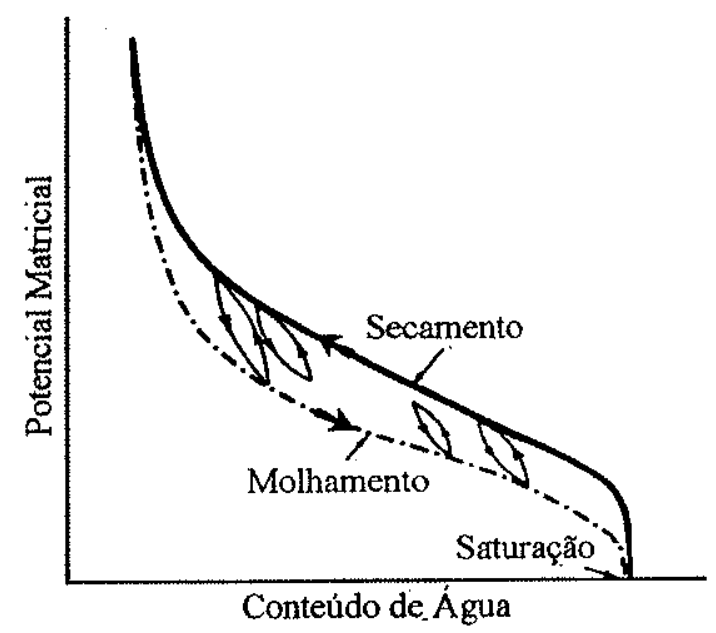

Figura 3.5 - Efeito da histerese (HILLEL, 1980a)

"Várias equações empíricas têm sido propostas para descrever esta função. VAN GENUTCHEN (1980) apresentou uma relação empírica entre o potencial matricial e o conteúdo volumétrico de água, definida pela expressão:

$\theta=\theta_{r}+\frac{\theta_{S}-\theta_{r}}{\left[1+(\alpha \psi)^{n}\right]^{m}}$

onde:

$\mathrm{n}=\frac{1}{1-\mathrm{m}}$

e

$\alpha=\frac{1}{\psi_{\mathrm{e}}}\left(2^{-\mathrm{m}}-1\right)^{1-\mathrm{m}}$

onde $\mathrm{m}$ é um parâmetro estimado através da curva de retenção solo-água. Para achar os parâmetros do solo de van Genuchten, uma curva de retenção de água-solo com potencial matricial variando de 0 a $15000 \mathrm{~cm}$ de água deve ser contruida. $\mathrm{O}$ valor de $\theta_{\mathrm{S}}$ é encontrado quando o potencial matricial na curva é zero e o valor de $\theta_{\mathrm{r}}$ corresponde a $\theta$ referente ao valor do 
potencial matricial de $-15000 \mathrm{~cm}$ de água. A figura 3.1 mostra esta plotagem. $O$ ponto $P$ na curva corresponde ao conteúdo de água $\theta_{p}$, que é calculado através da relação:

$\theta_{\mathrm{p}}=\frac{\theta_{\mathrm{S}}+\theta_{\mathrm{r}}}{2}$

A inclinação, $\mathrm{S}$, da curva no ponto $\mathrm{P}$ é determinada graficamente a partir da curva de retenção. Uma inclinação adimensional, $\mathrm{S}_{\mathrm{p}}$, é então achado da relação:

$S_{p}=\frac{S}{\theta_{S}-\theta_{r}}$

$\mathrm{O}$ parâmetro $\mathrm{m}$ pode ser determinado a partir do valor de $S_{p}$ utilizando uma das fórmulas seguintes:

$1-\exp \left(-0.85 \mathrm{~S}_{\mathrm{p}}\right)\left(0<\mathrm{S}_{\mathrm{p}} \leq 1\right)$

ou:

$1-\frac{0.5755}{\mathrm{~S}_{\mathrm{p}}}+\frac{0.1}{\mathrm{~S}_{\mathrm{p}}{ }^{2}}+\frac{0.025}{\mathrm{~S}_{\mathrm{p}}{ }^{3}}\left(\mathrm{~S}_{\mathrm{p}}>1\right)$

Os valores de $\mathrm{m}$ e $\alpha$ podem ser determinados a partir das equações $3.19,3.20$ e 3.16 , respectivamente, utilizando-se o valor da pressão de entrada de ar obtida na curva de retenção solo-água" (FETTER, 1993).

\subsection{5- Fluxo da água sob condição não saturada e saturada}

"Os fluxos de água do não saturado e do saturado são gerados por uma força motriz resultante do gradiente de potencial hidráulico, sendo a taxa de fluxo proporcional a este gradiente.

O fluxo de água sob condição não saturada envolve relações complexas entre as variáveis conteúdo de água, potencial matricial e condutividade hidráulica, cujas inter-relações são complicadas pelo fenômeno da histerese.

Em condições não saturadas a água tende a ser drenada de uma região onde os filmes de água, gerados pela adsorção, ao redor das partículas sólidas, são mais espessos para onde eles são mais finos e de uma região onde os meniscos capilares são menos curvados para onde eles são mais curvados, isto é, a água flui de uma região onde o potencial matricial é mais baixo para onde ele é mais alto, com a tendência de atingir o equilíbrio. 
A força motriz é maior na zona de frente da umidade ("wetting front zone"), onde a água invade e avança, em uma matriz originalmente seca. Nesta frente o gradiente de potencial matricial pode totalizar vários bar por centímetro de solo. Tal gradiente constitui uma força motriz milhares de vezes maior que a força gravitacional. Estas forças são requeridas para ocorrer movimento de água, pois em solos relativamente secos a condutividade hidráulica é extremamente baixa" (HILLEL, 1980a).

\subsection{6- Condutividade Hidráulica}

"A condutividade hidráulica é o coeficiente de proporcionalidade que descreve a taxa pela qual um fluído pode mover-se através de um meio permeável. Ela é uma função das características do meio e do fluído, expressando a quantidade de água que irá fluir através de uma seção de área unitária de um material poroso, por unidade de tempo, sob um gradiente hidráulico unitário, em uma temperatura específica" (BALLESTERO et al., 1991).

"Talvez a diferença mais importante entre os fluxos não saturado e saturado esteja na condutividade hidráulica. Quando o solo é saturado, todos os poros estão cheios e a água é conduzida por eles continuamente, ocasionando, portanto, condutividade hidráulica máxima. Quando o solo torna-se não saturado os poros apresentam ar e água, reduzindo, portanto, a porção condutora de água. Além disso, quando a sucção se desenvolve, os primeiros poros a esvaziar são os maiores, restando somente água fluindo em poros menores. Os poros vazios devem ser circundados pela água, portanto, com a desaturação, a tortuosidade aumenta" (HILLEL, 1980a).

"Em uma matriz com textura grossa, sob condições não saturadas, a água permanece nas bordas capilares formando pacotes separados e descontínuos de água. Os espaços integranulares grandes, quando não saturados, tornam-se barreiras para o fluxo. Por esta razão, a transição da saturação para a não saturação implica em uma queda abrupta no valor da condutividade hidráulica, que pode decrescer várias ordens de grandeza. A valores de sucção ou umidade baixos, a condutividade hidráulica é tão baixa, que é requerido um gradiente de sucção e um tempo muito grande para ocorrer algum fluxo apreciável de água (HILLEL, 1980a). Desta forma a condutividade hidráulica não saturada é uma função do conteúdo de água, $\theta$, ou uma função do potencial matricial, $\psi$ "(FETTER, 1993).

"Sob condições saturadas os solos, sedimentos ou rochas, que apresentam valores mais elevados de condutividade hidráulica, são os que possuem poros contínuos e grandes, enquanto os menores valores são observados nas matrizes sólidas com poros pequenos. Entretanto o oposto é verdade, quando sob condições não saturadas. Nos materiais não saturados com poros pequenos, 
vários poros retém e conduzem a água, mesmo sob sucções apreciáveis, portanto, a condutividade hidráulica não varia tão abruptamente quanto em um material não saturado com poros grandes.

Considerando uma amostra de solo não saturada, na qual a água está fluindo sob sucção e que a diferença de potencial, entre a entrada e a saída do fluxo é mantida por sucções impostas, diferentes e constantes, observar-se-á que o fluxo será constante, mas o gradiente de sucção irá variar ao longo da amostra. Uma vez que o produto do gradiente e a condutividade hidráulica é constante, para fluxo constante, o gradiente de sucção irá aumentar quando a condutividade decrescer, com o aumento de sucção, ao longo da amostra.

Uma vez que o gradiente de suç̧ão não é constante ao longo da amostra, não é possível dividir o fluxo pelo gradiente de potencial hidráulico, para obter a condutividade hidráulica não saturada, pois seria necessário dividir o fluxo pelo gradiente de sucção exato em cada ponto para avaliar a condutividade hidráulica exata e sua variação com a sucção neste determinado ponto.

Assumindo que a amostra é curta suficientemente para permitir avaliar a condutividade hidráulica não saturada média, para a amostra como um todo e fazendo sucessivas medidas do fluxo versus gradiente de sucção para diferentes valores de sucção média, observou-se que a inclinação da linha de fluxo versus gradiente, que é a condutividade hidráulica, varia com a variação de sucção média. No caso de fluxo saturado, ao contrário, a condutividade hidráulica independe do potencial de pressão positivo" (HILLEL, 1980a).

O fluxo da água na zona não saturada é influenciado pela temperatura. Uma mudança de 2 a $25^{\circ} \mathrm{C}$ pode causar aumento da condutividade hidráulica não saturada por muitas ordens de grandeza (FETTER, 1993).

CONSTANTZ (1982, in FETTER 1993) escreveu a seguinte expressão para relacionar a condutividade hidráulica não saturada com a permeabilidade intrínseca do solo:

$K(\theta)=\frac{k_{r}(\theta) k \rho_{W} g}{\mu_{W}}$

onde $\mathrm{kr}$ é a condutividade relativa, que é a razão da condutividade hidráulica não saturada, a uma dada umidade, pela condutividade hidráulica saturada; $\mathrm{k}$ é a permeabilidade intrínseca e $\mu_{\mathrm{W}}$ é a viscosidade dinâmica da água do solo a uma dada temperatura. $\mathrm{O}$ efeito da temperatura na condutividade hidráulica não saturada é devida ao efeito da temperatura sobre a viscosidade dinâmica do fluido considerado. 
"A condutividade hidráulica não saturada pode ser determinada por métodos de campo e de laboratório. Entretanto estes métodos são demorados e tediosos, com limitações práticas numerosas. Desta forma, a condutividade hidráulica não saturada é frequentemente estimada através de parâmetros obtidos da curva de retenção solo-água" (VAN GENUCHTEN, 1980).

VAN GENUCHTEN (1980) apresentou as expressões que relacionam a condutividade hidráulica não saturada ao conteúdo de água e ao potencial matricial. A relação entre a condutividade hidráulica não saturada e conteúdo de água é:

$\mathrm{K}(\theta)=\mathrm{K}_{\mathrm{S}} \mathrm{S}_{\mathrm{e}} 1 / 2\left[1-\left(1-\mathrm{S}_{\mathrm{e}} 1 / \mathrm{m}\right)^{\mathrm{m}}\right]^{2}$

onde $\mathrm{K}_{\mathrm{S}}$ é a condutividade hidráulica saturada e $\mathrm{S}_{\mathrm{e}}$ é definido pela expressão:

$\mathrm{S}_{\mathrm{e}}=\frac{\left(\theta-\theta_{\mathrm{r}}\right)}{\left(\theta_{\mathrm{S}}-\theta_{\mathrm{r}}\right)}$

A relação equivalente entre a condutividade hidráulica não saturada e o potencial de pressão negativo ou matricial é:

$\mathrm{K}(\psi)=\mathrm{K}_{\mathrm{S}} \frac{\left\{1-(\alpha \psi)^{\mathrm{n}-1}\left[1+(\alpha \psi)^{\mathrm{n}}\right]^{-\mathrm{m}}\right\}^{2}}{\left[1+(\alpha \psi)^{\mathrm{n}}\right]^{\mathrm{m} / 2}}$

onde $\mathrm{K}(\psi)$ é a condutividade hidráulica não saturada em função do potencial de pressão matricial $\psi$.

3.2.7- Fluxo preferencial na zona não saturada

"As análises precedentes tratam a zona não saturada como um meio poroso homogêneo. Entretanto, este não é certamente o caso. Além do fluxo darciano, na zona não saturada pode ocorrer fluxo de água através de macroporos. Este fluxo envolve a transmissão rápida de água (ou fluídos) através de poros ou canais grandes e contínuos constituidos por fraturas, falhas, e outras. É importante não confundir o fluxo darciano através de poros grandes, com o fluxo desenvolvido nestas porosidades secundárias"(FETTER, 1993). 
"A profundidade de penetração do fluxo através de macroporos depende do conteúdo de água, intensidade e duração da precipitação e a natureza dos macroporos. A presença de fluxo por macroporos pode ocasionar a chegada de poluentes na zona saturada mais rapidamente do que a velocidade prevista pelo cálculo do fluxo darciano na zona não saturada" (USEPA, 1986a).

"Na zona das raízes existem numerosos poros grandes e fraturas formados por agentes como plantas, fraturas de contração-dilatação e perfurações feitas por animais. Estes macroporos podem formar caminhos preferenciais para o movimento da água e solutos, verticalmente e horizontalmente" (BEVEN \& GERMANN, 1982 in FETTER, 1993).

"Um segundo tipo de fluxo preferencial é o "fingering", que ocorre quando uma frente de infiltração uniforme de soluto é separada em várias partes no sentido vertical descendente, devido a instabilidade causada por variações de permeabilidade em escala de poros. Frequentemente ocorre instabilidade quando uma frente de molhamento avançando chega a uma fronteira onde um sedimento mais fino sobrepõe um sedimento mais grosseiro" (HILLEL \& BAKER, 1988 in FETTER, 1993).

"Um terceiro tipo de fluxo preferencial é o afunilamento ("funneling") (KUNG, 1990 in FETTER, 1993), que está associoado com perfis de solo ou sedimento estratificado. Uma camadas inclinada com material grosseiro intercalada entre camadas de material fino pode impedir o fluxo vertical descendente da água, pois esta camada irá coletar a água, como os lados de um funil e direcionar o fluxo para o fim desta camada, onde então poderá percolar verticalmente, em um volume concentrado".

"Estas ocorrências de fluxo preferencial e heterogeneidades da zona não saturada causam complicações para o monitoramento dos solutos na zona vadosa. Alguns estudos têm registrado resultados anômalos semelhantes, com camadas de solo mais profundas apresentando concentrações maiores de soluto do que camadas de solo mais rasas (KUNG, 1990 in FETTER, 1993). Estas anomalias podem ser explicadas por padrões de fluxo preferencial. Isto sugere que um grande número de sistemas de amostragem serão necessários para obter-se uma avaliação acurada da distribuição dos contaminantes na zona vadosa. O fluxo preferencial na zona vadosa tem implicações também no monitoramento da zona saturada, pois, por exemplo, no caso de uma substância que está sendo constantemente espalhada sobre a superfície do terreno, como uma substância química aplicada na agricultura, pode-se esperar, que uma taxa constante de soluto esteja chegando ao lençol freático via zona vadosa. Entretanto, devido a fluxos preferenciais o soluto pode ser concentrado em algumas regiões resultando em uma distribuição não uniforme na água subterrânea rasa, abaixo do local, podendo os poços de monitoramento abaixo do local apresentar concentrações variáveis de solutos" (FETTER, 1993). 


\subsection{8- Equações de fluxo não saturado}

Em 1856, trabalhando com colunas de areia saturada, Darcy concluiu que o fluxo de água por unidade de área da coluna e na unidade de tempo, é proporcional à diferença de carga hidráulica medida em dois pontos em consideração. O coeficiente de proporcionalidade, condutividade hidráulica, é uma propriedade do meio poroso em transmitir o líquido.

BUCKINGHAN (1907, in FETTER 1993) reconheceu que o potencial matricial, $\psi$, é uma função do conteúdo volumétrico de água, $\theta$, da temperatura e da densidade global do solo e que o fluxo de água através de uma seção de área unitária é proporcional ao gradiente de potencial. Reconheceu também que a constante de proporcionalidade $\mathrm{K}$ é uma função do conteúdo de água, $\theta$ (FETTER, 1993). Buckinghan parecia não ter conhecimento do trabalho de Darcy (SPOSITO, 1986 in FETTER, 1993).

"O movimento da água em um meio poroso obedece a Lei da Conservação das Massas. A aplicação desta lei pela equação da continuidade, por Richards, resultou na equação geral que descreve o movimento da água em meio não saturado:

$\mathrm{q}=-\mathrm{K}(\psi) \nabla(\phi)$

onde $\nabla(\phi)$ é o gradiente de potencial total da água do solo ou gradiente de potencial hidráulico, incluindo os componente gravitacional, z, e de pressão ou sucção, $\psi$ (FETTER, 1993; HILLEL, 1980a).

Esta formulação pode ser falha, levando-se em consideração o fenômeno da histerese. Este problema pode ser evitado, na prática, limitando-se a utilização das equações da continuidade para situações, nas quais, as mudanças dos valores de sucção ou umidade crescem ou diminuem continuamente" (HILLEL, 1980a).

Segundo HILLEL (1980a), "a relação da condutividade hidráulica não saturada com a umidade volumétrica $K(\theta)$ é afetada pela histerese em um grau muito menor que a função $K(\psi)$. Portanto a Lei de Darcy pode ser escrita da seguinte forma:

$q=-K(\theta) \nabla(\phi)$

A equação da continuidade para a umidade do solo através de um volume representativo elementar (REV) da zona não saturada pode ser definido como a mudança do conteúdo 
volumétrico total de água com o tempo e é igual à soma de qualquer mudança no fluxo de água para dentro e para fora do REV. A equação da continuidade pode ser expressa por:

$\frac{\partial \theta}{\partial t}=-\left(\frac{\partial q_{x}}{\partial x}+\frac{\partial q_{y}}{\partial y}+\frac{\partial q_{z}}{\partial z}\right)$

onde qx, qy, e qz são fluxos da água do solo. Em notação vetorial a equação anterior pode ser escrita da seguinte maneira:

$\frac{\partial \theta}{\partial \mathrm{t}}=-\nabla \mathrm{q}$

portanto, combinando as equações 3.28 e 3.26 obtem-se a equação de Richards:

$\frac{\partial \theta}{\partial \mathrm{t}}=\nabla[\mathrm{K}(\psi) \nabla \phi]$

Como o potencial hidráulico é a soma do potencial de pressão negativa $(\psi)$ e do potencial gravitacional (ou elevação z), pode-se escrever:

$\frac{\partial \theta}{\partial \mathrm{t}}=\nabla[\mathrm{K}(\psi) \nabla \Phi]-\frac{\partial \mathrm{K}(\psi)}{\partial \mathrm{z}}$

Para fluxo unidimensional a equação acima reduz-se para:

$\frac{\partial \theta}{\partial \mathrm{t}}=\frac{\partial}{\partial \mathrm{z}}\left[\mathrm{K}(\psi) \frac{\partial \psi}{\partial \mathrm{z}}\right]-\frac{\partial \mathrm{K}(\psi)}{\partial \mathrm{z}}$

Desta forma, conforme destacam HILLEL (1980a) e FETTER (1993), "considerando-se desprezivel o gradiente de potencial gravitacional em comparação com o gradiente de potencial matricia, pode-se considerar:

$\frac{\partial \theta}{\partial \mathrm{t}}=\frac{\partial}{\partial \mathrm{z}}\left[\mathrm{K}(\psi) \frac{\partial \psi}{\partial \mathrm{z}}\right]$

As equações precedentes assumem temperatura e pressão de ar constantes, uma matriz de solo não deformável, água incompressível e que a densidade da água do solo é indenpendente da concentração dos solutos, não variando através do domínio do fluxo. Além disso, estas equações assumem que a presença de ar pode ser ignorada, exceto quando ela afeta o valor de $\mathrm{K}$. A 
equação 3.31 não é linear, sendo de difícil solução. Entretanto, métodos numéricos de solução destas equações tem sido desenvolvidos" (NIELSEN et al., 1986 in FETTER, 1993).

\section{3- Movimento de solutos na zona não saturada}

"Quando a água do solo move-se através do perfil, ela carrega consigo solutos, através do fluxo convectivo, além de deixar uma parte deste soluto adsorvido, retido por plantas ou precipitado. Os solutos não se movem apenas com a água do solo, mas também em resposta a gradientes de concentração. Ao mesmo tempo, os solutos reagem entre si e interagem com a matriz sólida em uma sucessão cíclica de processos físico-químicos interrelacionados. Estas interações envolvem e são fortemente influenciadas por variáveis como temperatura, acidez, potencial redox, composição e concentração da solução do solo" (HILLEL, 1980a).

\subsection{1- Convecção}

"A convecção ou advecção é o processo primário responsável pela migração de solutos em meios porosos. $\mathrm{O}$ movimento se dá em resposta a um gradiente de potencial hidráulico, desta forma a movimentação do soluto acontece como resultado da movimentação da água como um todo, mantendo as mesmas concentrações na solução, quando esta se dirige para regiões de menor potencial hidráulico. A convecção da água do solo, chamada de fluxo darciano carrega com ela um fluxo convectivo de solutos, Jc, proporcional às suas concentrações, c, da seguinte forma:

$$
J_{c}=q c=-c\left(K \frac{d H}{d x}\right)
$$

onde $\mathrm{J}_{\mathrm{c}}$ é dado em termos de massa de soluto passando através de uma secção unitária de um meio poroso, por unidade de tempo (ML-2 $\left.\mathrm{T}^{-1}\right)$ " (HILLEL, 1980a).

\subsection{2- Difusão}

Segundo HILLEL (1980a), "se os solutos não são distribuídos uniformemente na água do solo, gradientes de concentração irão existir, tendendo a ocorrer difusão de solutos, de onde suas concentrações são mais altas para onde são mais baixas.

$\mathrm{Na}$ água, a taxa de difusão, $\mathrm{J}_{\mathrm{d}}\left(\mathrm{ML}^{-2}\right)$, é relacionada, pela Primeira Lei de Fick, com o gradiente de concentração, $\nabla c$ :

$$
\mathrm{J}_{\mathrm{d}}=-\mathrm{D}_{\mathrm{o}} \frac{\mathrm{dc}}{\mathrm{dx}}
$$


sendo $\mathrm{D}_{\mathrm{o}}\left(\mathrm{L}^{2} \mathrm{~T}^{-1}\right)$, o coeficiente de difusividade (ou difusão) do soluto na água e dc/dx o gradiente de concentração.

$O$ coeficiente de difusividade da solução do solo, $\mathrm{D}_{\mathrm{S}}\left(\mathrm{L}^{2} \mathrm{~T}^{-1}\right)$, é menor que o coeficiente de difusividade, $\mathrm{D}_{\mathrm{O}}$, por várias razões.

A fase líquida ocupa apenas uma fração do volume total da zona não saturada e os caminhos da solução nos poros são tortuosos. Em um solo não saturado, quando a umidade é decrescente, o volume de água disponivel para a difusão diminui e a tortuosidade aumenta. Desta forma o coeficiente de difusividade em um solo não saturado, $\mathrm{D}_{\mathrm{S}}\left(\mathrm{L}^{2} \mathrm{~T}^{-1}\right)$, pode ser definido como:

$\mathrm{D}_{\mathrm{S}}=\mathrm{D}_{\mathrm{o}} \theta \xi$

sendo $\xi$, o fator de tortuosidade, que é expresso pela razão do comprimento da amostra de solo considerada, pelo comprimento médio do caminho tortuoso, que o soluto irá percorrer através dos poros. Este parâmetro depende da conteúdo de água e da configuração geométrica na qual a água se encontra retida nos poros. Desta forma, $D_{S}$ é dependente de $\theta$ diretamente e indiretamente através da dependência do parâmetro $\xi$ por $\theta$, portanto pode-se escrever $D_{S}(\theta)$.

Outros fatores adicionais reduzem o coeficiente de difusão, $\mathrm{D}_{\mathrm{S}}$, sob condições não saturadas, principalmente em solos argilosos.

Portanto, foi definido o fator de complexidade, $\alpha$, para avaliar todos os fatores envolvidos na diminuição do coeficiente de difusividade, $\mathrm{D}_{\mathrm{S}}$, em relação a $\mathrm{D}_{\mathrm{O}}$, desta forma:

$\mathrm{D}_{\mathrm{S}}=\mathrm{D}_{\mathrm{o}} \theta \alpha$

A equação da difusão de solutos em um meio não saturado, para processos de difusão em equilíbrio dinâmico, assume a forma:

$\mathrm{J}_{\mathrm{d}}=-\mathrm{D}_{\mathrm{S}}\left(\theta \frac{\mathrm{dc}}{\mathrm{dx}}\right)$

Para processos transientes, nos quais a taxa e concentração variam com o tempo, utiliza-se a equação da continuidade.

Considerando um REV, que contém uma fase líquida, circundado por dois planos quadrados paralelos de área $\mathrm{A}$, separados por uma distância $\Delta \mathrm{x}$ : 
$\mathrm{A}\left(\frac{\partial \mathrm{c}}{\partial \mathrm{t}}\right) \Delta \mathrm{x}=\mathrm{A}\left(\mathrm{J}_{\mathrm{d}}+\frac{\partial \mathrm{J}_{\mathrm{d}}}{\partial \mathrm{x} \Delta \mathrm{x}}\right)-\mathrm{AJ}_{\mathrm{d}}$

que reduz-se a:

$$
\frac{\partial \mathrm{c}}{\partial \mathrm{t}}=\frac{\partial \mathrm{J}_{\mathrm{d}}}{\partial \mathrm{x}}
$$

Combinando com a equação da difusão obtem-se:

$$
\frac{\partial c}{\partial t}=\frac{\partial\left[D_{S}\left(\theta \frac{\partial c}{\partial x}\right)\right]}{\partial x}
$$

Quando $\mathrm{D}_{\mathrm{S}}$ é considerado constante a equação apresenta forma análoga à Segunda Lei de Fick, apresentada a seguir:

$$
\frac{\partial \mathrm{c}}{\partial \mathrm{t}}=\mathrm{D}_{\mathrm{s}} \frac{\partial^{2} \mathrm{c}}{\partial \mathrm{x}^{2}}
$$

\subsection{3- Dispersão Hidrodinâmica}

"O fluxo convectivo da solução afeta os processos de difusão pela mudança da distribuição dos solutos e por induzir o processo chamado de dispersão hidrodinâmica.

A movimentação de qualquer solução não homogênea em um corpo poroso gera este processo, que difere da difusão no seu mecanismo, mas tende a produzir um efeito análogo, que é misturar e eventualmente igualar a concentração entre porções diferentes da solução.

A dispersão hidrodinâmica ou mecânica resulta da não uniformidade da velocidade de fluxo nos poros condutores. A água move-se mais rápido através de poros grandes do que nos pequenos e é mais rápido no centro dos poros do que ao longo dos seus limites. Desta forma, algumas partes da solução movem-se na frente de outras. Este fato causa a mistura de soluçôes diferentes e a intensidade deste fenômeno depende da velocidade convectiva de fluxo, distribuição dos poros, grau de saturação e gradientes de concentração.

Matematicamente a dispersão é formulada de maneira análoga à difusão:

$\mathrm{D}_{\mathrm{h}}=\mathrm{a} \overrightarrow{\mathrm{v}}$ 
sendo que o coeficiente de dispersão $\mathrm{D}_{\mathrm{h}}$, depende, mais ou menos linearmente da velocidade média e a é um parâmetro empírico" (HILLEL, 1980a).

O parâmetro a corresponde a dispersividade para fluxo saturado, que é uma função das características do meio geológico, conforme apresentado em CLEARY (1991).

\subsection{4- Difusão + dispersão}

"Por causa do efeito similar, a difusão e a dispersão são combinados em um termo chamado coeficiente de difusão-dispersão, $\mathrm{D}_{\text {sh: }}$ :

$D_{\text {sh }}(\theta, \bar{v})=D_{S}(\theta)+D_{h}(\bar{v})$

O fluxo total unidimensional de solutos na zona vadosa é o resultado da advecção, difusão molecular e dispersão hidrodinâmica. Com a difusão e dispersão hidrodinâmica combinados como o coeficiente de dispersão da solução do solo, este pode ser expresso como:

$\mathrm{J}=\overline{\mathrm{v}} \theta \mathrm{c}-\mathrm{D}_{\operatorname{sh}} \theta \frac{\mathrm{dc}}{\mathrm{dx}}$

onde $\mathrm{J}$ é o fluxo de massa de soluto através de uma secção de área unitária na unidade de tempo, $\mathrm{D}_{\text {sh }}$ é o coeficiente de difusão-dispersão da solução do solo, que é uma função de $\theta$ e v, para equilíbrio dinâmico" (FETTER, 1993).

"Para processos transientes, nos quais fluxos e concentrações podem variar no tempo e no espaço, a equação da continuidade para o fluxo de solutos requer que a taxa de mudança de massa de soluto presente em um volume elementar representativo (REV) seja igual a diferença entre o fluxo de soluto indo para dentro do REV e aquele que sai do REV. A massa total de soluto é a soma da massa de soluto dissolvida e a massa de qualquer soluto associado com a fase sólida do solo. A massa do soluto dissolvida é igual ao produto de $\theta$ e $\mathrm{c}$. A massa de soluto presa ao solo é o produto da densidade global, $\mathrm{B}_{\mathrm{d}}$, e a concentração da fase de soluto presa no solo, $\mathrm{c}^{*}$. A equação da continuidade para o soluto é:

$\frac{\partial\left(\mathrm{B}_{\mathrm{d}} \mathrm{c}^{*}\right)}{\partial \mathrm{t}}+\frac{\partial(\theta \mathrm{c})}{\partial \mathrm{t}}=-\frac{\partial \mathrm{J}}{\partial \mathrm{z}}$

combinando as equações 3.43 e 3.45 obtemos: 


$$
\frac{\partial\left(\mathrm{B}_{\mathrm{d}} \mathrm{c}^{*}\right)}{\partial \mathrm{t}}+\frac{\partial(\theta \mathrm{c})}{\partial \mathrm{t}}=\frac{\partial(\mathrm{v} \theta \mathrm{c})}{\partial \mathrm{z}}+\frac{\partial}{\partial \mathrm{z}}\left(\mathrm{D}_{\mathrm{S}} \theta \frac{\partial \mathrm{c}}{\partial \mathrm{z}}\right)
$$

\subsection{5- Fontes e sumidouros}

"Podem existir também fontes e sumidouros de soluto não representados pela concentração adsorvida, $\mathrm{c}^{*}$. Por exemplo, as plantas podem remover nutrientes da solução e solutos podem ser originados por decaimento biológico, assim como transformações e precipitações microbianas e químicas. Estes podem ser adicionados à equação 3.46 por um termo $\gamma_{\mathrm{i}}$, a qual torna-se a equação fundamental de transporte de massa para a zona vadosa:

$$
\frac{\partial\left(\mathrm{B}_{\mathrm{d}} \mathrm{c}^{*}\right)}{\partial \mathrm{t}}+\frac{\partial(\theta \mathrm{c})}{\partial \mathrm{t}}=\frac{\partial}{\partial \mathrm{z}}\left(\mathrm{D}_{\mathrm{sh}} \theta \frac{\partial \mathrm{c}}{\partial \mathrm{z}}-\mathrm{qc}\right)+\sum_{\mathrm{i}} \gamma_{\mathrm{i}}
$$

Assumindo-se Bd, Ds, $\theta$,e q como sendo constantes no tempo e no espaço, a equação 3.47 reduz-se a equação 3.48 , que é a equação unidimensional básica de advecção-dispersão.

$$
\frac{\partial \mathrm{C}}{\partial \mathrm{t}}=\mathrm{D}_{\mathrm{L}} \frac{\partial^{2} \mathrm{C}}{\partial \mathrm{x}^{2}}-\mathrm{v}_{\mathrm{x}} \frac{\partial \mathrm{C}}{\partial \mathrm{x}}-\frac{\mathrm{B}_{\mathrm{d}}}{\theta} \frac{\partial \mathrm{C}^{*}}{\partial \mathrm{t}}+\left(\frac{\partial \mathrm{C}}{\partial \mathrm{t}}\right)_{\mathrm{rxn}}
$$

onde $\mathrm{C}$ é a concentração do soluto na fase líquida, $\mathrm{t}$ é o tempo, $\mathrm{D}_{\mathrm{L}}$ é o coeficiente de dispersão, $\mathrm{v}_{\mathrm{X}}$ é a velocidade linear da fase líquida, $\mathrm{C}^{*}$ é a quantidade de soluto adsorvida por unidade de massa do sólido e rxn indica uma reação química ou biológica do soluto" (FETTER, 1993).

\subsubsection{1- Modelos de equilíbrio de transporte de massa}

"Para um soluto, que pode estar nas formas dissolvida ou adsorvida, é necessário conhecer-se a relação entre a concentraçãodo mesmo em solução, c, e a concentração adsorvida, $\mathrm{c}^{*}$. Se o soluto atinge o equilíbrio rapidamente entre as fases dissolvida e adsorvida, então a relação pode ser descrita por um isoterma de adsorção, por exemplo, uma isoterma linear:

$$
\mathrm{c}^{*}=\mathrm{K}_{\mathrm{d}} \mathrm{c}
$$

onde $\mathrm{K}_{\mathrm{d}}$, o coeficiente de distribuição, é a inclinação do gráfico de $\mathrm{c}^{*}$ como uma função de c. 
Se $\eta_{\mathrm{i}}$ e $\eta_{\mathrm{S}}$ são taxas constantes para decaimento de primeira ordem nas fases líquidas e sólidas respectivamente, e $\xi$ l e $\xi_{\mathrm{S}}$ são termos de taxa de ordem zero para a produção nas fases líquidas e sólidas então:

$\gamma_{\mathrm{i}}=-\eta_{\mathrm{i}} \theta \mathrm{c}-\eta_{\mathrm{s}} \mathrm{B}_{\mathrm{d}} \mathrm{c}^{*}+\xi_{\mathrm{l}} \theta+\xi_{\mathrm{S}} \mathrm{B}_{\mathrm{d}}$

Substituindo as equações 3.49 e 3.50 na equação 3.47 e simplificando-se os termos, pode-se obter a seguinte equação:

$\mathrm{R} \frac{\partial \mathrm{c}}{\partial \mathrm{t}}=\mathrm{D}_{\mathrm{S}} \frac{\partial^{2} \mathrm{c}}{\partial \mathrm{z}^{2}}-\mathrm{v} \frac{\partial \mathrm{c}}{\partial \mathrm{z}}-\eta \mathrm{c}+\xi$

onde $\mathrm{R}$ é o fator de retardamento, que é dado por:

$$
\mathrm{R}=1+\frac{\mathrm{B}_{\mathrm{d}} \mathrm{K}_{\mathrm{d}}}{\theta}
$$

e $\eta$ e $\xi$ são fatores dados por:

$$
\begin{aligned}
& \eta=\eta_{1}+\frac{\eta_{\mathrm{s}} \mathrm{B}_{\mathrm{d}} \mathrm{K}_{\mathrm{d}}}{\theta} \\
& \xi=\xi_{1}+\frac{\xi_{1} \mathrm{~B}_{\mathrm{d}}}{\theta}
\end{aligned}
$$

A equação 3.51 é baseada no fluxo em equilíbrio dinâmico, com o conteúdo volumétrico de água e a velocidade do fluído sendo constantes" (FETTER, 1993).

\subsubsection{2- Modelos de transporte de massa não equilíbrio}

"A solução do solo pode mover-se a uma taxa tão rápida, que um soluto pode não atingir a posição de equilibrio em relação às reações químicas que estão ocorrendo. Uma formulação de não equilíbrio surge quando processos de adsorção podem ser descritos por uma equação linear de primeira ordem. Sob esta condição, assumindo fluxo em estado constante e ignorando o termo fonte/sumidouro, a equação 3.51 pode ser escrita como um sistema conjugado (NIELSEN et al.,1986 in FETTER, 1993), como segue:

$$
\frac{\mathrm{B}_{\mathrm{d}}}{\theta} \frac{\partial \mathrm{c} *}{\partial \mathrm{t}}+\frac{\partial \mathrm{c}}{\partial \mathrm{t}}=\mathrm{D}_{\mathrm{S}} \frac{\partial^{2} \mathrm{c}}{\partial^{2} \mathrm{z}}-\mathrm{v} \frac{\partial \mathrm{c}}{\partial \mathrm{z}}
$$


$\mathrm{e}$

$\frac{\mathrm{dc}^{*}}{\mathrm{dt}}=\zeta_{\mathrm{r}}\left(\mathrm{K}_{\mathrm{d}} \mathrm{c}-\mathrm{c}^{*}\right)$

onde $\zeta_{\mathrm{r}}$ é o coeficiente de primeira ordem da taxa. As equações 3.55 e 3.56 tem sido usadas para descrever transporte em condições de não equilíbrio em solos. Como mostra VAN GENUCHTEN et al. (1974, in FETTER, 1993), o modelo de taxa de primeira ordem não tem melhorado materialmente a descrição do transporte em não equilíbrio nos solos. Um modelo alternativo de transporte em não equilíbrio surge quando a água do solo é assumida como constituída de uma fase móvel e uma imóvel. A fase móvel ocupa o centro dos poros saturados. A água imóvel consiste de uma fina camada sobre as partículas sólidas, poros com zonas mortas e água aprisionada em pequenos poros não saturados (COATS \& SMITH, 1964 in FETTER, 1993). A troca de solutos entre as fases móveis e imóveis ocorrem devido a difusão. Em adição, o soluto em ambas as fase imóvel e móvel podem participar nas reações de adsorção-desorção. Para a isoterma tipo Freundlich de equilíbrio linear, esta conceitualização pode ser descrita pelas seguintes equações (VAN GENUCHTEN \& WIERENGA, 1976 in FETTER, 1993):

$$
\begin{aligned}
& \theta_{m} R_{m} \frac{\partial c_{m}}{\partial t}+\theta_{i m} R_{i m} \frac{\partial c_{i m}}{\partial t}=\theta_{m} D_{s m} \frac{\partial^{2} c_{m}}{\partial z^{2}}-\theta_{m} v_{m} \frac{\partial c_{m}}{\partial z} \\
& \theta_{i m} R_{i m} \frac{\partial c_{i m}}{\partial t}=\beta\left(c_{m}-c_{i m}\right)
\end{aligned}
$$

onde $\beta$ é o coeficiente de transferência de massa, $R_{m}$ é o fator de retardamento para a água móvel, $R_{i m}$ é o fator de retardamento para a água imóvel, $c_{m}$ é a concentrção de soluto na água móvel e $c_{\mathrm{im}}$ é a concentração de soluto na água imóvel, $\theta_{\mathrm{m}}$, é o conteúdo de água móvel, $\theta_{\mathrm{im}}$, é o conteúdo de água imóvel e $\mathrm{D}_{\mathrm{Sm}}$, é o coeficiente de dispersão da solução do solo para a água móvel" (FETTER, 1993).

\subsubsection{3- Exclusão de ânions}

De acordo com FETTER (1993), "para um soluto não reativo, a equação 3.45 pode ser escrita como:

$\theta \frac{\partial c}{\partial t}=D_{s} \theta \frac{\partial^{2}}{\partial z^{2}}-q \frac{\partial c}{\partial z}$ 
Muitos solutos são considerados não reativos, a medida em que não são adsorvidos às superfícies das partículas. Nesta categoria estão incluídos ânions como o cloreto. Entretanto, como o cloreto carrega carga negativa e existem muitas partículas argilosas no meio poroso, a camada dupla eletrostática poderá repelir ânions. Consequentemente, existe uma região ao redor de cada partícula coloidal da qual os ânions são repelidos. Como uma primeira aproximação, pode-se assumir que há uma distribuição de fase dupla do soluto na água do solo.(JAMES \& RUBIN, 1986 in FETTER, 1993). O volume da zona de exclusão é $\theta_{\text {ex }}$.

A concentração de ânions na água do poro sob condições de exclusão de ânions é dada por (BRESLES, 1973 in FETTER, 1993):

$$
\left(\theta-\theta_{e x}\right) \frac{\partial c}{\partial t}=D_{s} \theta \frac{\partial^{2} c}{\partial z^{2}}-q \frac{\partial c}{\partial z}
$$

onde c é a concentração do soluto na solução no poro (que é incluido a água da zona de exclusão).

O valor de $\theta_{\text {ex }}$ pode ser achado experimentalmente através de um teste de coluna. A água com concentração inicial de um ânion $c_{o}$ é introduzida dentro de uma coluna de solo que tem conteúdo de água conhecido, que é mantido constante, e introduzido até que a concentração da água deixando a coluna do solo, $\mathrm{c}_{\mathrm{out}}$, seja igual a $\mathrm{c}_{\mathrm{O}}$. A massa de ânion contida na coluna de solo é determinada e uma concentração é calculada, baseado no conteúdo total de água na coluna de solo, $c_{\text {calc }}$. Esta concentração calculada de solução aniônica é menor que $c_{\text {out }}$, pois a água em exclusão de volume, que não contem ânions, foi usada no cálculo. $O$ valor do volume de exclusão pode ser achado de (BOND et al., 1992 in FETTER, 1993):

$\theta_{\mathrm{ex}}=\theta\left[1-\left(\frac{\mathrm{c}_{\text {calc }}}{\mathrm{c}_{\text {out }}}\right)\right]$

Em adição ao decréscimo da concentração do ânion na coluna do solo, a exclusão de ânions causa que o aumento da velocidade do ânion em soluçâo em relação a taxa média do movimento da água pura.

A taxa média do movimento da água pura nos poros, v, é igual a taxa do fluxo do fluído, $q$, dividido pelo conteúdo de água, $\theta$. Os ânions não podem viajar através da parte excluída do conteúdo volumétrico de água, que está próximo das superfícies e tem uma velocidade baixa ou zero. Portanto, eles devem mover-se na parte da água do poro que está disponível para eles, isto é, o centro dos poros, onde a velocidade do fluído é maior que a média. Como resultado, os 
ânions excluídos irão viajar mais em um dado período de tempo do que na ausência da exclusão de ânions.

Uma solução aproximada para a equação 3.60, para condições de conteúdo uniforme de água e um fluxo constante de um ânion dissolvido de concentração $c_{0}$ em uma coluna de solo semiinfinita, com uma concentração de ânions dissolvidos, $c_{i}$, é:

$$
\frac{c-c_{i}}{c_{o}-c_{i}}=0.5 \operatorname{erf}\left\{\frac{\left(\theta-\theta_{e x}\right) z-q t}{2\left[\left(\theta-\theta_{e x}\right) D_{s} \theta t\right]^{0.5}}\right\}
$$

\section{4- Monitoramento da Zona Não Saturada}

A estratégia tradicional de monitoramento das águas subterrâneas constitue-se, basicamente, de um processo de coleta de amostras de água, retiradas de poços de monitoramento, com o intuito de detectar a existência ou evidências de contaminação. Esta abordagem não é lógica, quando o propósito deste monitoramento é a prevenção da contaminação das águas subterrâneas, pois neste caso, a evidência da presença da contaminação será detectada quando o recurso a ser protegido já foi comprometido. Em contraste, o monitoramento da zona não saturada permite a detecção da presença e da migração dos contaminantes antes destes atingirem a zona saturada, permitindo a tomada de decisões que visam evitar o comprometimento da qualidade da água subterrânea e/ou reduzir custos e dificuldades técnicas associadas à recuperação da qualidade destas (WILSON, 1981; CULLEN et al., 1992; USEPA, 1986a).

DURAN et al. (1993), consideram que as redes de monitoramento da zona não saturada podem ser um complemento da rede de monitoramento da zona saturada e em certos locais onde a zona saturada é relativamente profunda, o monitoramento da zona vadosa pode reduzir a extensão do monitoramento da zona saturada.

NIELSEN et al. (1990 in CULLEN et al. 1991), revisaram o estado da arte dos modelos matemáticos utilizados para prever o transporte de contaminantes através da zona não saturada. Estes autores citam que as previsões do transporte de solutos na zona vadosa permanece sem um desenvolvimento adequado, devido a pequena confiança nos modelos de transporte de contaminantes existentes, causada por heterogeneidades texturais e por padrões de fluxo preferenciais. Deste modo, o monitoramento da zona vadosa permanece uma necessidade.

Três tipos de parâmetros são medidos na zona vadosa: propriedades de armazenamento, transmissão (fluxo) e qualidade do fluído (WILSON, 1981; BALLESTERO et al., 1991). 


\subsection{1 - Monitoramento das propriedades de armazenamento}

As propriedades físicas da zona vadosa principalmente utilizadas para descrever o armazenamento da água na zona não saturada são: densidade global ("bulk density"), espessura, porosidade, conteúdo de água e a relação umidade versus tensão (potencial matricial) ou sucção (curva de retençãos solo-água) (BALLESTERO et al., 1991).

\subsubsection{1- Espessura}

A espessura da zona vadosa pode ser determinada diretamente através da medição do nível de água em poços ou piezômetros. Se na área existe um aqüífero suspenso, a profundidade até o nível do aqüífero suspenso pode ser considerado a espessura da zona vadosa se este for utilizado para abastecimento (SILKA \& SWEARINGEN, 1978 in USEPA, 1980). Para aqüiferos semiconfinados, a profundidade até o lençol freático do aqüifero livre subjacente deve ser considerada. Para aqüíferos confinados, a distância até a base da camada confinante superior pode ser utilizada, na ausência de um aqüifero livre.

A espessura da zona vadosa não é constante, pois muda em resposta a bombeamento, recarga e descarga.

Métodos indiretos, como os métodos geofísicos podem ser utilizados para estimar a espessura da zona vadosa (USEPA, 1980).

\subsubsection{2- Densidade global}

"A densidade global de um solo, sedimento ou rocha é a relação de sua massa seca pelo seu volume total. Para determinar a densidade global devem ser utilizadas amostras indeformadas. Métodos indiretos como o método de radiação gama também podem ser utilizados para determinar a densidade global" (BOUWER, 1978 in USEPA, 1980).

\subsubsection{3- Porosidade}

"A porosidade de um solo ou rocha é a porcentagem do volume total de um meio poroso ocupado por poros ou outras aberturas.

A porosidade total representa o limite máximo para o armazenamento de água (saturação) e pode ser facilmente determinada em laboratório ou indiretamente através da determinação da densidade global" (USEPA, 1980). 


\subsubsection{4- Conteúdo de água e potencial matricial da água na zona não saturada}

Sob condições não saturadas uma certa quantidade de água permanece nos poros, sendo que este conteúdo de água ou umidade, pode ser expresso de várias maneiras: relativa à massa de sólidos, à massa total, ao volume de sólidos, ao volume total e ao volume de poros (HILLEL, 1980a). A tésnica básica de laboratório para determinar o conteúdo volumétrico de água, corsiste em pesar uma amostra indeformada, secar a amostra e pesar a amostra seca. Este método é conhecido como método gravimétrico (WILSON, 1981).

A relação do conteúdo de água com o potencial matricial da água da zona não saturada é representada pela curva de retenção solo-água. Para obter estas curvas no laboratório, a pressões negativas abaixo de $-800 \mathrm{~cm}$ de água, o método modificado de Haines pode ser utilizado.

Amostras de solo indeformadas são colocadas sobre uma placa de vidro sinterizado. Após saturar as amostras, o excesso de água é removido e a coluna de água é ajustada através de um intervalo definido de cargas negativas. As amostras são pesadas após a água do solo ter equilibrado com cada carga negativa sucessiva. No fim do teste, as amostras são secas e massas intermediárias são convertidas a valores de conteúdo volumétrico de água (USEPA, 1980).

Como o valor de entrada de ar para o meio de tensão é cerca de 0.8 atm de pressão negativa, outros métodos são requeridos para obter o conteúdo de água versus o potencial matricial para pressões negativas maiores.

Comumente, o método da câmara de pressão é utilizado. Como descrito por PAETZOLD (1979 in USEPA 1980), a amostra é saturada e colocada em uma câmara de pressão sobre uma placa de cerâmica ou uma membrana de celulose-acetato.

Uma pressão positiva de ar é aplicada à amostra indeformada, dentro da câmara, causando movimento da água da amostra através da membrana. $O$ valor da pressão de ar corresponde à carga de pressão negativa que retem a água na amostra. Os vários valores de entrada de ar das membranas permitem um intervalo de pressões possiveis de leitura. Após o conteúdo de água da amostra equilibrar na pressão de ar aplicada, a amostra é removida e pesada (USEPA, 1980).

Medidas do conteúdo e potencial da água na zona não saturada podem ser obtidas, em campo, através da utilização de tensiômetros, blocos de resistência elétrica, psicrômetros de par térmico ("thermocouple psychrometers"), espalhamento da radiação gama ("gama-ray atenuation") e moderaçâo de neutrons ("nuclear magnetic resonance") (BALLESTERO et alii, 1991). 
Conhecendo-se o potencial matricial no campo através de leituras nos tensiômetros, obtem-se o valor do conteudo volumétrico de água, utilizando-se a curva característica (USEPA, 1980).

"Um tensiômetro consiste de uma cápsula porosa conectada a um manômetro através de um tubo cheio de água (figura 3.6). A operação é baseada no princípio de que quando a cápsula é colocada no solo, a água contida no tensiômetro está geralmente a pressão atmosférica. A água do solo, estando sob pressões negativas, exerce uma sucção, causando drenagem de uma certa quantidade de água para fora do tensiômetro, que gera uma queda na pressão hidrostática, que é registrada no manômetro. Um tensiômetro instalado por um longo período de tempo tende a seguir as mudanças do potencial matricial. $O$ uso de vários tensiômetros a diferentes profundidades pode indicar os gradientes de potencial hidráulico na zona não saturada, conhecendo-se a cota de um plano referencial" (HILLEL, 1980a).

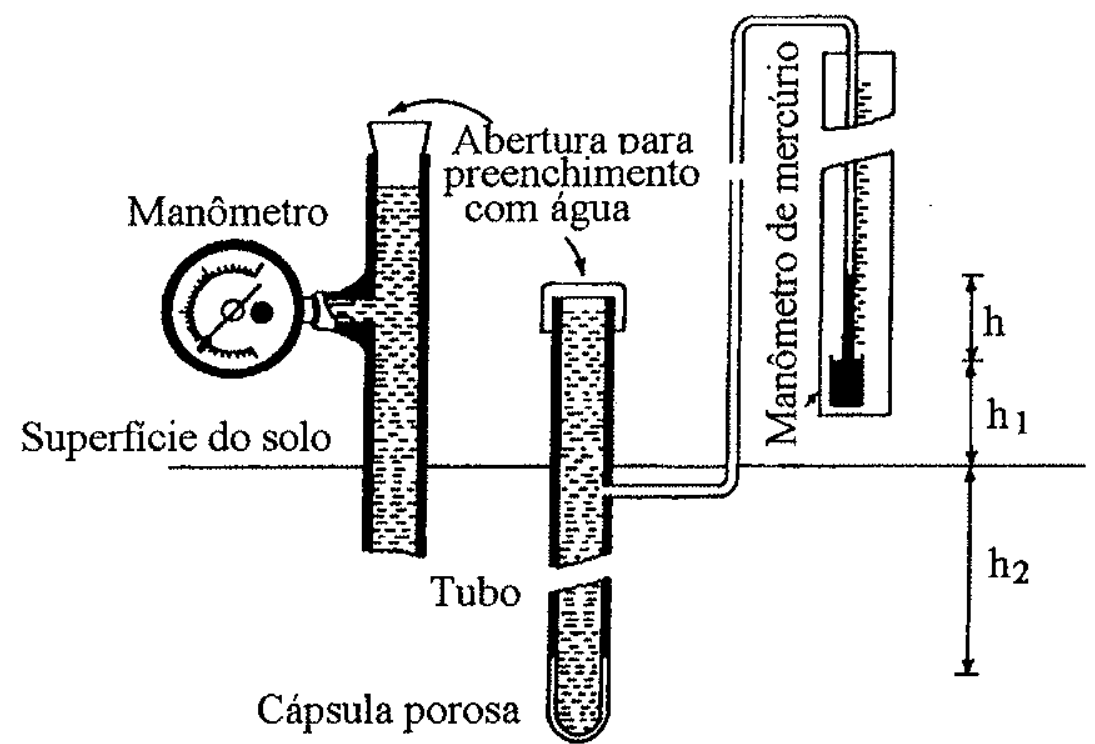

Figura 3.6 - Tensiômetro (HILLEL, 1980a)

As leituras devem ser corrigidas subtraindo-se o peso da coluna de água entre a superfície do solo e o manômetro. Para assegurar operação apropriada, o tensiômetro deve ser instalado com a menor deformação do solo possível, para que a cápsula porosa seja conectada hidraulicamente com o solo ao redor. Isto pode ser conseguido forçando a cápsula em uma abertura estreita ou pela colocação da cápsula juntamente com um lodo do material removido do buraco (BALLESTERO et al. 1991).

"Os tensiômetros são utilizados para determinar-se a direção do movimento da água, ascendente ou descendente. Os estudos com tensiômetros podem ter as seguintes aplicações: na 
hidrogeologia, para conhecer a época e a duração da recarga de aqüúferos; na agricultura, parà determinar-se a época de irrigação e a quantidade de água a ser aplicada; na aplicação de fertilizantes, pesticidas, etc., para prevenção da poluição das águas subterrâneas" (SZIKSZAY, 1990).

"As desvantagens de todos os tipos de tensiômetros incluem um limite baixo de medidas de tensão, aproximadamente 1 bar, com o decréscimo de exatidão nas leituras sob tensões maiores. As leituras são sensíveis a mudanças de temperatura, pressão atmosférica e bolhas de ar nas linhas de água. Os tensiômetros com tubos condutores de água com diâmetro pequeno são especialmente suscetiveis a bolhas de ar e requer o preenchimento com água frequente para assegurar leituras exatas. Em adição, devido a necessidade de utilizar a curva característica para determinar a umidade utilizando-se tensiômetros, é necessário saber se o solo está secando ou sendo umidecido quando a medida é efetuada, devido ao fenômeno da histerese. Outras fontes de erro são: erros de leitura do operador e falhas na calibração" (BALLESTERO et al., 1991).

"Os psicrômetros de par térmico são usados para medir o potencial hidráulico na zona não saturada sob condições muito secas, onde os tensiômetros não podem ser usados devido a presença de grandes pressões negativas. Os psicrômetros são compostos de um bulbo poroso, um par térmico, um sumidouro de calor, um eletrodo de referência e um circuito. Os psicrômetros tem medido com sucesso valores de sucção maiores que 30 atmosferas" (WATSON, 1974 in BALLESTERO et al., 1991).

"As desvantagens destes equipamentos são: sensibilidade a variações de temperatura, requerem calibração antes da instalação no campo, necessidade correção devido às mudanças de temperatura, e o alto custo e complexidade destes instrumentos" (BRUCE \& LUXMORE, 1986 in BALLESTERO et al., 1991).

"Os blocos de resistência elétrica são baratos e podem ser usados para medir o conteúdo de água e o potencial matricial da água da zona não saturada. Eles consistem de duas placas de metal colocadas dentro de um material poroso, usualmente gipso. Fios elétricos são presos às placas permitindo medidas das mudanças na resistividade elétrica entre as duas placas. Quando o conteúdo de água do bloco de resistência elétrica varia, em acordo com as variações do conteúdo de água da zona não saturada, as propriedades de resistência elétrica do bloco são alteradas podendo ser registradas. As vantagens dos blocos de resistência elétrica são: eles são apropriados para uso geral no estudo das relações solo-água; são baratos e requerem pouca manutenção. Embora os blocos de resistência elétrica apresentem-se como uma alternativa atraente de monitoramento, eles tem problemas que podem torná-los inúteis em certas situações, pois possuem sensibilidade à temperatura, a calibração é demorada, e a pouca exatidão das medidas 
com alto conteúdo de água. Eles são geralmente usados apenas para sucções acima de 0.8 atm, que é o limite superior de sucção para os tensiômetros. Em adição, os blocos de resistência elétrica são feitos de gipso que eventualmente dissolve, não sendo ứilizáveis para longos períodos" (BALLESTERO et al., 1991).

"A técnica do espalhamento da radiação gama pode ser usada indiretamente para medir o conteúdo de umidade através da determinação, não destrutiva, da densidade do solo. A radiação é aplicada utilizando-se uma fonte de Césio que passa através de tubos de acesso locados na zona não saturada. Se a densidade do material permanece constante, as mudanças na atenuação da radiação refletirão mudanças no conteúdo de umidade. Esta técnica requer aberturas de acesso paralelas, para a fonte e o detector. As medidas podem ser tomadas em intervalos próximos a $2 \mathrm{~cm}$, tanto verticalmente como horizontalmente, permitindo uma determinação exata da localização da frente de molhamento.

As maiores desvantagens desta tecnologia são que as unidades de atenuação de raios gama são caras e difícies de serem usadas, requerendo cuidados especiais no manejo da fonte radioativa e as mudanças na densidade global afetam a calibração do instrumento" (BALLESTERO et al., 1991).

"Um segundo método nuclear para medidas não destrutivas do conteúdo de umidade é a moderação de neutrons. Neste método uma sonda, contendo uma fonte de neutrons e um detector, é abaixada em um tubo de acesso, que é constituido por um tubo de alumínio ou aço. Os neutrons emitidos de uma fonte radioativa interagem com o hidrogênio na água do solo em volta. Das contagens da radioatividade tiradas, em intervalos, o conteúdo de umidade pode ser calculado. Este método tem várias qualidades positivas (SCHMUGGE, 1980 in BALLESTERO et al., 1991). As leituras são diretamente relacionadas com a umidade do solo e o conteúdo de umidade pode ser medido. Conteúdos médios de umidade podem ser determinados com a profundidade. Medidas repetidas podem ser tiradas no mesmo local, permitindo medidas de mudanças rápidas no conteúdo de umidade, assim como mudanças em intervalos maiores. $\mathrm{O}$ sistema pode ser interligado com equipamentos gravadores.

Esta técnica também apresenta várias desvantagens. Os equipamentos são muito caros, apenas o conteúdo de umidade pode ser medido, nenhuma informação é fornecida sobre o potencial da água do solo ou mudanças de densidade. Devido a esfera de influência, medidas exatas não podem ser tiradas próximo da superfície do solo. Em adição, a exatidão do método não é alta para detectar pequenas mudanças no conteúdo de água, especialmente para solos secos. Este método requer cuidado no manejo da fonte radioativa" (BALLESTERO et al., 1991). 
"Recentemente a técnica chamada de "time-domain reflectometry" (TDR) tem sido utilizada como um método exato, não destrutivo, rápido para medidas do conteúdo volumétrico de água. As medidas realizadas não são afetadas significativamente pela textura do solo, densidade, temperatura ou conteúdo de sal, não necessitando, desta forma de calibração para diferentes solos. A técnica é baseada no princípio de que a constante dielétrica da água é aproximadamente 80 vezes maior que a constante dielétrica do solo, desta forma o método TDR é muito sensível a mudanças no conteúdo volumétrico de água" (REICHARDT, 1985).

\subsection{2- Monitoramento das propriedades transmissão (fluxo)}

"O monitoramento do fluxo de água na zona não saturada é realizado para caracterizar a quantidade e a velocidade da solução durante seu trânsito nesta zona. O fluxo é definido como a quantidade de fluído atravessando uma área unitária em um tempo unitário. Informações sobre o fluxo são úteis na previsão da quantidade de solução que chega no lençol freático. Estimativas da velocidade podem ser usadas para calcular o tempo de trânsito de contaminantes na zona vadosa" (WILSON, 1982).

"Medidas de campo das taxas de infiltração são apropriadas para estimar a transmissão descendente de fluido durante o ciclo de molhamento. A infiltração é um processo pelo qual a água entra em um material permeável. Quando a infiltração ocorre em um solo seco a taxa de infiltração é inicialmente governada pelo potencial matricial dentro da zona não saturada. Mais tarde, quando o perfil torna-se molhado para profundidades cada vez maiores, os gradientes de suç̧ão diminuem e a gravidade torna-se a força predominante na promoção do fluxo descendente e a taxa de infiltração decresce assintóticamente, sendo chamada de infiltrabilidade. Eventualmente, a taxa aproxima-se do equilíbrio dinâmico, aproximadamente igual à condutividade hidráulica saturada, se o perfil é homogêneo" (HILLEL, 1980b).

"Os três estágios da transmissão na zona vadosa são infiltração, percolação e recarga. A infiltração é o processo de movimento de água através da superfície do terreno para dentro do solo. A percolação é o movimento da solução através dos canais condutores na zona vadosa. A recarga consiste no movimento de líquido para a zona saturada. As taxas de recarga são iguais a percolação próximo do lençol freático" (WILSON, 1982).

HILLEL (1980b) diferencia a drenagem em um perfil molhado inteiramente sobre um lençol freático raso e a drenagem para um perfil sobre uma zona não saturada profunda. No primeiro caso a drenagem ocorre inteiramente em todo o perfil. No segundo caso a parte superior do perfil drena enquanto o material inicialmente seco na parte inferior torna-se molhado. A água desta 
forma torna-se redistribuída no perfil. Uma sucessão de perfis de conteúdo de água obtidos durante a redistribuição poderia mostrar o deslocamento gradual da umidade do solo.

"Não existem métodos diretos para medir a condutividade hidráulica não saturada, pois esta é urna função do conteúdo de umidade. Entretanto, pode-se medir o fluxo e usá-lo para calcular as taxas de transmissão do fluído. A taxa de movimento da umidade do solo é determinada indiretamente através de taxas de infiltração ou medidas de fluxo não saturado" (BALLESTERO et al., 1991).

\subsubsection{1 - Medidas de campo das taxas de infiltração}

"Para calcular a condutividade hidráulica através de dados de infiltração, o gradiente hidráulico e a extensão lateral do fluxo devem ser conhecidos. Os dados de gradiente podem ser obtidos usando vários intrumentos descritos nas seções prévias. A condutividade hidráulica saturada deve ser conhecida, pois ela é o limite superior para a condutividade hidráulica não saturada" (HILLEL, 1980b).

"A infiltração é determinada utilizando-se de infiltrômetros, que podem ser projetados com um anel simples ou com anel duplo. O método do anel duplo é mais utilizado, pois seu desenho minimiza o fluxo lateral, simplificando o cálculo da condutividade hidráulica saturada. $O$ princípio da operação é baseada na manutenção de uma carga constante no interior do infiltrômetro e nos anéis externos do infiltrômetro. Ambos os anéis são selados no solo para previnir fugas abaixo dos anéis. A água é adicionada aos anéis para manter a carga constante e se o interior dos anéis é coberto para previnir evaporação, o volume de água adicionado ao interior dos anéis é igual a água infiltrando no solo. A condutividade hidráulica pode ser calculada da taxa de infiltração usando a Lei de Darcy ou a Aproximação de Green-Ampt. Se a Lei de Darcy é utilizada, a equação é:

$\mathrm{K}=-\frac{\mathrm{Q}}{(\mathrm{AI})}$

onde $\mathrm{Q} / \mathrm{A}$ é a infiltrabilidade em equilíbrio dinâmico por unidade de área e I é o gradiente hidráulico determinado de dados de tensiômetros. Q/A é negativa pois o fluxo é descendente. Este método assume que o fluxo está ocorrendo sob condições saturadas.

A aproximação de Green-Ampt assume que a frente de molhamento é pontuda ("sharp"), o potencial matricial na frente é constante, e a zona úmida é uniformemente molhada e que a condutividade hidráulica é constante. A suposição de uma frente de molhamento pontuda pode ser apropriada para solos com granulometria fina. A aproximação de Green-Ampt difere do 
cálculo da Lei de Darcy, pois o conhecimento da profundidade da frente de molhamento é requerida, em vez de um gradiente hidráulico medido. Sob estas suposições, a solução analítica para a infiltração vertical produz uma equação que assemelha-se com a equação de Darcy:

$K=i\left[1+\frac{h+\psi_{f}}{L_{f}}\right]^{-1}$

onde i é a taxa de infiltração em equilíbrio dinâmico e o termo entre parênteses é o gradiente hidráulico. No termo entre parênteses, h é a altura de água no infiltrômetro, $\psi_{\mathrm{f}}$ é o potencial matricial na frente de molhamento e $\mathrm{L}_{\mathrm{f}}$ é a profundidade da frente de molhamento. Para estimativas conservativas, $\psi_{\mathrm{f}}$ é estimado ser zero" (BALLESTERO et al., 1991).

\subsubsection{2- Calculo do fluxo e velocidade de fluxo}

"A infiltração em equilíbrio dinâmico, discutida acima, é uma base apropriada para determinação do fluxo durante o ciclo de molhamento. Durante o ciclo de secamento, três maiores aproximações são possíveis (EVERETT, 1980 in BALLESTERO et al., 1991). A primeira consiste em calcular o fluxo através de fórmulas matemáticas e relações empíricas entre a sucção do solo, conteúdo de água e condutividade hidráulica; a segunda, medindo mudanças no conteúdo de água no perfil do solo durante o tempo; e a terceira, fazendo-se medidas diretas utilizando-se medidores de fluxo.

O método disponível mais fácil para calcular o fluxo saturado através de dados de infiltrômetros é o uso da Lei de Darcy. Este método é conservativo, pois assume que o solo está saturado; ele é apropriado para o ciclo de molhamento quando o fluxo em equilíbrio dinâmico é determinado através de um teste de infiltração. Em termos simples, resolvendo para a velocidade média linear, $\mathrm{V}_{\mathrm{X}}$, a Lei de Darcy pode ser escrita como:

$\mathrm{V}_{\mathrm{x}}=\frac{\mathrm{Q}}{\mathrm{n}_{\mathrm{e}} \mathrm{A}}$

onde $\mathrm{Q}$ é a discarga, $\mathrm{n}_{\mathrm{e}}$ é a porosidade efetiva, e A é a área da secção transversal do fluxo. Q/A é a taxa de infiltração em estado constante por unidade de área; para usar na Lei de Darcy, Q/A é negativo pois o fluxo é descendente.

O modelo da frente de molhamento de Green-Ampt é utilizado com dados de infiltração e assume condições não saturadas abaixo da frente de molhamento. $O$ tempo de transporte (velocidade vezes a distância) é calculado de: 
$t=\left\{\frac{\theta_{S}-\theta_{i}}{K_{\text {sat }}}\right\}\left[L_{f}-\left(h+\psi_{f}\right) \ln \left\{1+\frac{L_{f}}{h+\psi_{f}}\right\}\right]$

onde $\theta_{\mathrm{S}}$ e $\theta_{\mathrm{i}}$ são os conteúdos de água inicial e saturado, $\mathrm{L}_{\mathrm{f}}$ é a profundidade até a frente de molhamento, h é a profundidade da lâmina d'água, e $\psi_{\mathrm{f}}$ é o potencial de umidade imediatamente abaixo da frente de molhamento".

"O método da drenagem interna pode ser usado para determinar a condutividade hidráulica não saturada no campo pelo monitoramento da drenagem interna transiente de um perfil de solo próximo da superfície. O método é descrito em detalhe por HILLEL (1980a) e foi extendido para perfis acamadados por HILLEL et al. (1972 in BALLESTERO et al., 1991). Ele requer medidas simultâneas de conteúdo de água e sucção sob condições de drenagem interna; a evapotranspiração deve ser evitada. O método também assume que o fluxo é vertical e que o lençol freático é profundo o suficiente para que ele não afete o processo de drenagem.

Tensiômetros e tubos de acesso para sonda de neutrons ou blocos de gipso são instalados próximos do centro da área do teste. Os intervalos de profundidades para os instrumentos não devem exceder $30 \mathrm{~cm}$, com uma profundidade total desejável acima de $2 \mathrm{~m}$. A área teste é então enchida ou irrigada até que o perfil do solo esteja molhado. Medidas simultâneas da sucção do solo e do conteúdo de umidade são coletadas até que a sucção do solo exceda 0.5 bar; a uma sucção maior, o processo de drenagem pode ser tão devagar que as mudanças tornam-se imperspectíveis.

O período de medição para este teste pode ser várias semanas, para solos que drenam devagar. Os dados são plotados em dois gráficos, conteúdo de água e sucção versus tempo para cada profundidade medida no perfil do solo. Destas medidas valores instantâneos do gradiente de potencial e fluxo podem ser obtidas, permitindo o cálculo da condutividade hidráulica e, portanto, a velocidade de fluxo" (BALLESTERO et al., 1991).

\subsection{3- Monitoramento da qualidade da água na zona não saturada}

O objetivo principal de um programa de monitoramento da zona não saturada é medir as mudanças no tempo e no espaço da qualidade da água.

Três tipos de métodos dão disponíveis para monitorar a qualidade da água na zona vadosa: métodos indiretos, medidas diretas da água dos poros de amostras de solo e amostragem direta da água do solo/BALLESTERO et al., 1991). 


\subsubsection{1- Métodos indiretos}

Os métodos indiretos para monitoramento da zona vadosa incluem a utilização de técnicas geofísicas como a eletrorresistividade e eletromagnética. $O$ sucesso da utilização das propriedade elétricas para delinear plumas depende do contraste entre a condutividade da pluma e da água natural, profundidade e espessura da pluma e das variações da geologia. Podem ser utilizados também blocos de resistência elétrica para avaliar a salinidade do solo (BALLESTERO et al., 1991).

\subsubsection{2- Amostragem do solo}

O uso de amostras de solo para caracterizar a zona não saturada é recomendado para determinar o comportamento de elementos "menos móveis", isto é, que se movimentam vagarosamente ou ficam retidos nas primeiras camadas do solo (BROWN, 1986; USEPA, 1986a).

$\mathrm{O}$ uso de amostras de solo apresenta problemas operacionais por ser um método destrutivo. Em solos estruturados e/ou não homogêneos é muito dificil retirar-se amostras representativas dos vários horizontes, além de ocorrer problemas de contaminação cruzada em locais contaminados (BROWN, 1986).

Outro método de obtenção de água da zona não saturada é a extração desta do solo coletado através de um filtro prensa ou centrífuga, mas este método apresenta grande desvantagem por ser destrutivo (USEPA, 1986a).

\subsubsection{3 - Amostragem da água da zona não saturada}

Uma variedade de amostradores tem sido utilizada para coletar a água ou solução do solo (termo normalmente empregado em Física e Química do Solo) objetivando detectar o comportamento dos constituintes "mais móveis", que entram em solução, que podem chegar até a zona saturada (USEPA, 1986a).

Basicamente, dois princípios tem sido utilizados para projetar amostradores de água da zona não saturada: coleta por vácuo ou sucção utilizando-se material poroso e coleta por drenagem livre ou gravidade (HORNBY et al., 1986; BROWN, 1986).

O primeiro princípio é aplicado para amostrar a água da zona não saturada que flui através dos poros, ou seja, amostrar a água que encontra-se sob fluxo darciano. O segundo é aplicado para 
amostrar a água que flui através de canais, buracos de raízes, canais em argilas ressecadas, solos estruturados, etc; denominado fluxo não darciano ou fluxo por macroporos (USEPA, 1986a).

Para selecionar o equipamento de monitoramento da qualidade da água da zona não saturada deve-se levar em conta os seguintes critérios: custos, disponibilidade comercial, requerimentos de instalação, interações com resíduo, limites de sucção, umidade do solo, características e regime de fluxo da água da zona não saturada, durabilidade, volume e profundidade de amostragem (USEPA, 1986a).

\subsubsection{1- Coleta por vácuo}

O lisímetro de sucção é o equipamento a vácuo mais amplamente utilizado (HORNBY et al., 1986). Ele permite a coleta de água dos poros da zona não saturada para análises química, cujos resultados são utilizados para controlar taxas de aplicação e identificar poluentes que podem estar migrando dentro da zona não saturada (NELSON, 1985).

Estes equipamentos apresentam uma vantagem significativa sobre a extração de água de amostras de solo, pois várias amostras de água podem ser retiradas do mesmo local (BALLESTERO et al., 1991).

PARIZEK \& LANE (1970) desenvolveram o lisímetro de sucção baseado em um protótipo descrito por WAGNER (1962). Através das modificações propostas tornou-se possível coletar água da zona não saturada até $15 \mathrm{~m}$ de profundidade aproximadamente, obtendo $700 \mathrm{ml}$ de água em média (figura 3.7).

WOOD (1973) apresentou um protótipo que permite a coleta de amostras a profundidades maiores que $15 \mathrm{~m}$. Este projeto previne a pressurização através de uma válvula, coletando amostras a profundidades superiores a $30 \mathrm{~m}$.

O lisímetro de sucção (figura 3.7) é constituído basicamente por um tubo e uma cápsula porosa. Quando instalado no solo, os poros da cápsula tornam-se uma extensão dos poros do solo.

Aplicando-se um vácuo no interior da cápsula, a pressão no interior desta será mais negativa do que a pressão no solo, ocorrendo assim fluxo de água para dentro da cápsula. A amostra, posteriormente, é recolhida para a superfície através da aplicação de uma pressão no interior do lísímetro, permitindo a coleta da amostra e a determinação da qualidade da água da zona não saturada (USEPA, 1986a). 


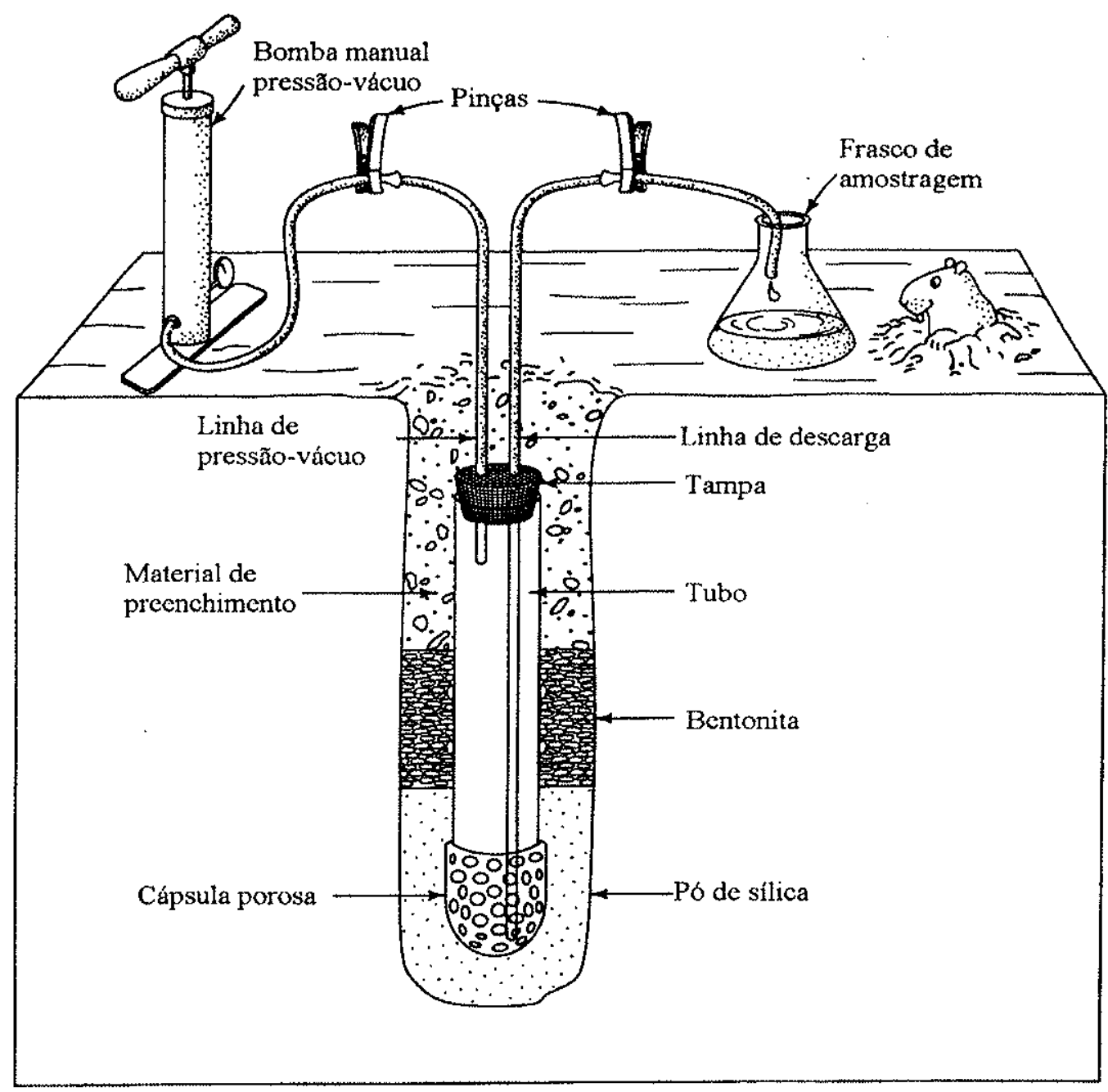

Figura 3.7 - Lisímetro de sucção (FETTER, 1993)

$\mathrm{Na}$ figura 3.7, a bentonita tem a função de isolar o lisímetro impedindo infiltrações de outros niveis. O pó de sílica, 200 mesh, é útil para proporcionar uma boa transmissão da solução do solo através de um bom contato hidráulico do solo com a cápsula e para preencher os espaços vazios criados durante a perfuração, além de proteger a cápsula do entupimento por colóides, matéria orgânica e outras partículas do solo (USEPA, 1986a).

As cápsulas porosas são normalmente confeccionadas com cerâmica, alumina ("alundum") ou PTFE (TEFLON). Os dois primeiros são hidrofilicos enquanto que o último é hidrofóbico (BALLESTERO et al., 1991).

SILKWORTH \& GRIGAL (1981) in HORNBY et al. (1986) indicam os amostradores com cápsula porosas como os melhores para coleta de água da zona não saturada. Estes são fáceis de instalar, baratos e podem ser instalados em áreas com atividades já desenvolvidas sem causar 
perturbação excessiva do solo e suas estruturas. Entretanto, alguns problemas podem existir, limitando seu uso em alguns casos.

Questões tem sido levantadas sobre a validade das amostras coletadas por lisímetros de sucção. Alguns estudos tem indicado que a cápsula de cerâmica pode alterar a composição química das amostras, tornando-as não representativas da qualidade real da amostra (BALLESTERO et al., 1991).

Além das alterações químicas das amostras, outros fatores tem sido levantados, como por exemplo: variações na composição da solução em períodos curtos de tempo, a distribuição do tamanho dos poros do solo onde está instalada a cápsula e o procedimento de amostragem isto é, quantidade de vácuo aplicados, tempo necessário para extrair a amostra e volume da amostra coletada (HORNBY et al., 1986).

Ocorrem vários problemas na operação dos lisímetros, entre eles podem ser citados: os métodos de instalação podem alterar significativamente as condições naturais, os materiais de construção dos lisímetros podem contribuir com constituintes químicos ou remover estes constituintes da amostra obtida, a aplicação de vácuo pode mudar o fluxo natural através dos poros, ou mudar a concentração química dos constituintes da amostra quando esta entra no lisímetro.

Os lisímetros de sucção não são recomendados para determinação de $\mathrm{DBO}$ e sólidos suspensos na água e bactérias, pois estes e outros materiais são filtrados pela cápsula (PARIZEK \& LANE, 1970). DAZZO \& ROTHWELL (1974 in BALLESTERO et al. 1991) citam que a filtração e adsorção das bactérias pelas cápsulas de cerâmica torna-as impróprias para análises de coliformes fecais.

GROVER \& LAMBORN (1970) citam que as cápsulas de cerâmica podem interferir no resultado das análises, podendo contribuir com quantidades excessivas de $\mathrm{Ca}^{+2}, \mathrm{Na}^{+1}$ e K para a solução que passa por ela, além de adsorver fósforo de soluções que o contém. Os mesmos autores propõem um pré-tratamento das cápsulas, fazendo passar por essas 50 e 60 volumes de poros de cápsula de $\mathrm{HCl} 1 \mathrm{~N}$ e 10 volumes de poros de cápsula de água deionizada. Este procedimento reduziu a contaminação para níveis aceitáveis de $\mathrm{Na}^{+1}$ e $\mathrm{Ca}^{+2}$, embora significativas quantidades de $\mathrm{Ca}^{+2}$ ainda tenham permanecido. A adsorção de fósforo foi reduzida, chegando a um nível de equilíbrio com a passagem de pouca quantidade de solução.

WOOD (1973) recomenda passar 1 litro de $\mathrm{HCl} 8 \mathrm{~N}$ pela cápsula porosa de cerâmica e 15 a 20 litros de água deionizada. A cápsula estará limpa quando a diferença entre a condutividade específica da água deionizada e da água que sai da cápsula for menor que $2 \%$. 
HANSEN \& HARRIS (1975) executaram testes de laboratório e de campo para determinar a representatividade das amostras para determinação de nitrato e fosfato da água do solo, coletada através de cápsula porosa de cerâmica. Foram encontradas interferências e variações substanciais. Algumas das causas apontadas foram: sorção, lixiviação, difusão e repulsão dos íns fosfato pelas paredes da cápsula, sendo a variação dos íons nitrato nas amostras causada pela taxa de entrada, entupimento, profundidade de amostragem e do tipo de sistema de vácuo empregado. Estes fatores afetam o tempo de coleta de amostra e, devido a contínua variação na concentração dos nutrientes na água do solo.

Diferentes resultados foram obtidos por LEVIN \& JACKSON (1977), que citam que as concentrações de $\mathrm{Ca}+2, \mathrm{Mg}^{+2}$, e $\mathrm{PO}_{4}^{-1}$ não alteraram durante a coleta de solução de solo usando-se cápsula porosa de cerâmica.

Cápsulas porosas de cerâmica foram comparadas com cápsula de teflon por ZIMMERMANN et al. (1978 in HAINES et al., 1982). As cápsulas de cerâmica coletaram $112 \%$ do $N H 4^{+1}$ e $43 \%$ do $\mathrm{PO}^{-1}$ da solução teste, enquanto que a cápsula de teflon recuperou $102 \%$ e $106 \%$ destes íons presentes na solução inicial.

SEVERSON \& GRIGAL (1976 in ANDERSON, 1986) notaram que a concentração de cálcio da amostra de solução de solo coletada varia com a sucção aplicada no amostrador e com o tempo de extração.

SEVERSON \& GRIGAL (1976 in HORNBY et al., 1986) identificaram duas classes de amostras obtidas com cápsulas porosas. A primeira classe consiste de amostragens com coleta rápida, e representa a solução do solo movendo-se através de poros maiores sob baixas tensões.

A segunda classe é extraída em períodos de tempo maiores e representa a solução de poros menores retida sob altas tensões.

ANDERSON (1986) cita que durante uma amostragem longa (uma semana), a sucção inicial de 80 centibares decresceu para zero, quando o fluído encheu o amostrador. Embora a alta sucção inicial colete a solução de poros pequenos, a amostra irá constituir-se predominantemente de solução proveniente dos poros maiores, devido a maior facilidade em remover a solução e as maiores velocidades de fluxo nestes poros.

A contribuição relativa da solução provinda de poros grandes e poros pequenos em uma amostra dependerá da distribuição do tamanho dos poros em contato com o amostrador, da área de influência de amostragem, da umidade residual do solo, da sucção do amostrador. 
Se as concentrações dentro de diferentes classes de tamanho de poros do solo variar, as concentrações amostradas dependerão da proporção dos fluídos provenientes de cada classe de tamanho dos poros.

COCHRAN et al. (1970 in LITAOR, 1988) citam que heterogeneidades do solo afetam a retenção da umidade do mesmo, causando fluxo não uniforme e irregular do solo para o amostrador. Eles concluiram que a aplicação de uma sucção contínua e constante na placa ou cápsula porosa faz crescer a variação no volume de lixiviados, especialmente em horizontes com diferentes propriedades de fluxo e retenção. Portanto o uso de amostrador com sucção constante causa um movimento da solução do solo diferente do movimento natural.

As amostras coletadas por vácuo são representativas de um volume de solo diferente do que seria se fossem coletadas sob fluxo natural, devido as perturbações, causadas pelo vácuo aplicado na cápsula, no fluxo (VAN DER PLOEG \& BEESE, 1977). Além disso o raio de influência de uma unidade que extrai água continuamente pode ser maior que em unidades descontínuas.

O raio de amostragem de um lisímetro é da ordem de centímetros, portanto vários aparelhos são necessários o conjunto funcionar como um sistema efetivo de prevenção (MORRISON \& LOWERY, 1990 in BALLESTERO et al., 1991).

Os estudos realizados antes de 1980 utilizaram soluções com baixas concentrações, relativamente, as quais resultam em altos erros de amostragem e variabilidade de amostras. Poucos trabalhos tem sido realizados para determinar os efeitos destes amostradores em amostras de solução do solo altamente contaminadas, embora estes amostradores estejam sendo utilizados comumente para monitorar solos altamente contamionados (BALLESTERO et al., 1991).

Sorção e repulsão de íons pela cápsula porosa de cerâmica podem mudar substancialmente a composição da solução amostrada, principalmente quando o contaminante amostrado é um ânion presente em baixas concentrações (ANDERSON, 1986).

SILKWORTH \& GRIGAL (1981) compararam quatro tipos de amostradores: com cápsula porosa de cerâmica pequena (2,2cm de diâmetro e 5,7 de cumprimento), com cápsula porosa de cerâmica grande $(4,8 \mathrm{~cm}$ de diâmetro e $6,2 \mathrm{~cm}$ de comprimento), com cápsula de vidro sinterizado ( $2,5 \mathrm{~cm}$ de diâmetro e $20 \mathrm{~cm}$ de comprimento) e com fibra de celulose ( $25 \mathrm{~cm}$ de comprimento). Concluiram que a cápsula de cerâmica grande é o melhor tipo de cápsula por ter sido a que provocou menor alteração na composição da solução do solo e apresentou menos falhas na obtenção das amostras. Estas cápsulas apresentaram valores semelhantes aos obtidos pelas cápsulas de vidro, que foram construídas com o objetivo de garantir a não interferência do 
material na amostra. Estas cápsulas de vidro, embora tenham-se mostrado adequadas para a coleta de amostras de água do solo, apresentam limitações quanio ao aito custo e fragilidade. STARR (1985), recomenda o uso de cápsulas de vidro sinterizado.

NAGPAL (1982 in LITAOR, 1988) cita que retenção de $\mathrm{NO}_{2}{ }^{-1}-\mathrm{Ne} \mathrm{NO}_{3}{ }^{-2}-\mathrm{N}$ foi mínima. Sugere que a pequena retenção observada de nitrogênio é provavelmente causada por difusão. Demonstra também que o $\mathrm{PO}_{4}{ }^{-1}-\mathrm{P}$ e $\mathrm{K}^{+1}$ são retidos pela cápsula de cerâmica durante a amostragem. A proporção que foram retidos depende da concentração da solução e o tempo de contato entre a solução e a cápsula porosa.

CREASEY \& DREISS (1985) realizaram um estudo comparando cápsulas de cerâmica, alumina e teflon lavadas e não lavadas com $\mathrm{HCl} 1 \mathrm{~N}$. As concentrações dos elementos traços e dos cátions maiores, lixiviados das cápsulas, são significativamente menores nas cápsulas lavadas do que nas não lavadas. Entretanto, mesmo após lavadas com 1 litro de $\mathrm{HCl} 1 \mathrm{~N}$, havia níveis detectáveis de contaminantes provindo das cápsulas para a solução.

Dos três materiais examinados, as cápsulas de cerâmica fornecem menores quantidades de metais traços e cátions maiores para solução do que as de teflon e alumina. Estas cápsulas contribuem com, relativamente, baixas quantidades de contaminantes exceto para $\mathrm{Ca}^{+2}$, quando não lavada, e quando lavada contribuem menos. Para ambas, lavadas e não lavadas, as cápsulas de alumina tendem a liberar maiores quantidades de $\mathrm{Mg}^{+2}$ e $\mathrm{Mn}^{+2}$ na solução que os outros dois materiais. $\mathrm{O}$ Teflon libera maiores quantidades de elementos traços $\mathrm{Fe}$ total, $\mathrm{Cu}^{+2}$ e $\mathrm{Cr}$ total de amostradores lavados e $\mathrm{Fe}$ total, $\mathrm{Cu}+2$ e $\mathrm{Cd}$ total nas não lavadas. Eles concluiram que as variações introduzidas pelas cápsulas porosas podem ser significativas apenas para amostras de água com baixas concentrações.

USEPA (1986a) sugere a utilização de teflon para a confecção do equipamento de monitoramento para minimizar a contaminação e interferências na amostra.

Lisímetros com cápsula de PTFE não seguram 10 centibar de vácuo (EVERETT et al., 1988 in BALLESTERO et al., 1991)

PETERS \& HEALY (1988) indicam que a validade da análise química da amostra depende de como a amostragem foi conduzida e dos materiais de construção dos aparelhos. Eles testaram o efeito da cápsula porosa sobre a qualidade química da amostra passando-se por esta uma solução com concentrações conhecidas dos constituintes e analizando a amostra. As análises indicaram que os íons maiores foram fracamente alterados, entretanto as concentrações dos metais traços tiveram grandes alterações. 
O potencial de contaminação das amostras por outros materiais dos lísimetros foram testados por PETERS \& HEALY (1988) comparando-se dados químicos das análises de água de lisímetros construídos com diferentes materiais. Os resultados indicaram que o cobre, PVC e aço inoxidável não tiveram influência na qualidade da amostra. Entretanto materiais galvanizados podem contribuir com zinco e manganês para a amostra.

Para assegurar que nenhuma contaminação é provinda do pó de sílica, PETERS \& HEALY (1988) realizaram estudos em laboratório. As águas subterrâneas do local de estudo, água destilada, e água destilada com ácido sulfúrico foram separadamente misturadas com pó de sílica. Elas foram filtradas posteriormente e analisadas para $\mathrm{pH}$, condutividade específica, alcalinidade e cloreto. Os resultados do estudo indicaram que as águas misturadas com o pó de sílica são muito similares com as águas antes da mistura.

O procedimento de instalação dos lisímetros causam perturbação no solo a ser monitorado. Estas perturbações são causadas pela perfuração e podem afetar os padrões de fluxo de água em volta do ponto de amostragem.

O processo de perfuração pode sujar e compactar as paredes da abertura, causando decréscimo da condutividade hidraúlica, reduzindo o raio de influência do amostrador. Este fator é muito importante em solos com textura fina (HORNBY et al., 1986).

Ao lado dos lisímetros de sucção, a determinação da umidade disponível no solo pode ser determinada através de vários equipamentos, descritos anteriormente, para verificar se os lisímetros estão funcionando bem.

Baseado em um extenso programa de testes com lisímetros, EVERETT et al. (1988 in BALLESTERO et al., 1991) descrevem as seguintes conclusões e recomendações:

- Antes da instalação no campo, os lisímetros devem ser testados com pressão para verificar a presença de vazamentos.

- A pressão aproximada de entrada de ar ou pressão de borbulhamento para cápsulas de cerâmica é 2.38 atm para cápsulas de fluxo baixo e 1.224 para as de fluxo alto e para cápsulas de PTFE é de 0.068 atm.

- Cápsulas de cerâmica de fluxo baixo são capazes de segurar seu vácuo por vários meses.

- Os lisímetros de PTFE devem ser usados com pó de silica.

- O uso de pó de sílica ao redor da cápsula porosa anula a maioria dos entupimentos associados às partículas finas do solo. 
- O intervalo de operação efetiva dos lisímetros de sucção está entre 0 e 60 centibar de sucção indiferentemente se foi usado pó de sílica.

- O intervalo operacional dos lisímetros de PTEF sem pó de sílica é extremamente estreito, mas com o uso de pó de sílica ele é extendido a cerca de 7 centibar de sucção.

- Orgânicos voláteis podem ser obtidos utilizando-se lisímetros de sucção onde o equilíbrio é estabelecido e mantido.

- Orgânicos voláteis são perdidos dos lisímetros de suç̧ão se o vácuo precisar ser reestabelecido intermitentemente para obter amostra suficiente.

\subsubsection{2- Amostradores de drenagem livre}

Os amostradores de drenagem livre são apropriados para a coleta de água da zona não saturada que flui, através de poros grandes e contínuos ou canais, para profundidades maiores que os previstos pela Lei de Darcy, durante um curto período de tempo após um evento de precipitação. Os lisímetros de sucção não são capazes de coletar estas águas (USEPA, 1986a).

Vários materiais e métodos tem sido utilizados na construção dos amostradores de drenagem livre. PARIZECK \& LANE (1970) construiram um panlisímetro de metal com a forma de uma pá. BARBEE (1983 in USEPA, 1986a) propos um amostrador composto por um bloco de vidro (figura 3.8).

Tipicamente os amostradores de drenagem livre são instalados em trincheiras, que após a instalação são preenchidas com o material do local. Este método mostrou-se viável em áreas ativas, não alterando as operações regulares do lugar.

Os amostradores de drenagem livre não tem sido usados tão extensivamente como os de cápsulas porosas. Informações sobre as suas performaces sobre diferentes condições são limitadas (HORNBY et al., 1986).

Existem alguns tipos de amostradores de drenagem livre que adicionam uma placa que proporciona uma tensão ou uma camada de areia fina que reduz a extensão das forças capilares na cavidade formada pelo aparelho, promovendo a entrada de água mais livremente (USEPA, 1986a). Neste contexto podemos citar o aparelho da TADROS \& MAC GARITY (1976).

Estão disponíveis também aparelhos que combinam os principios de drenagem livre e vácuo. Entre eles podemos citar o "wicking sampler", apresentado por HORNBY et al. (1986). 


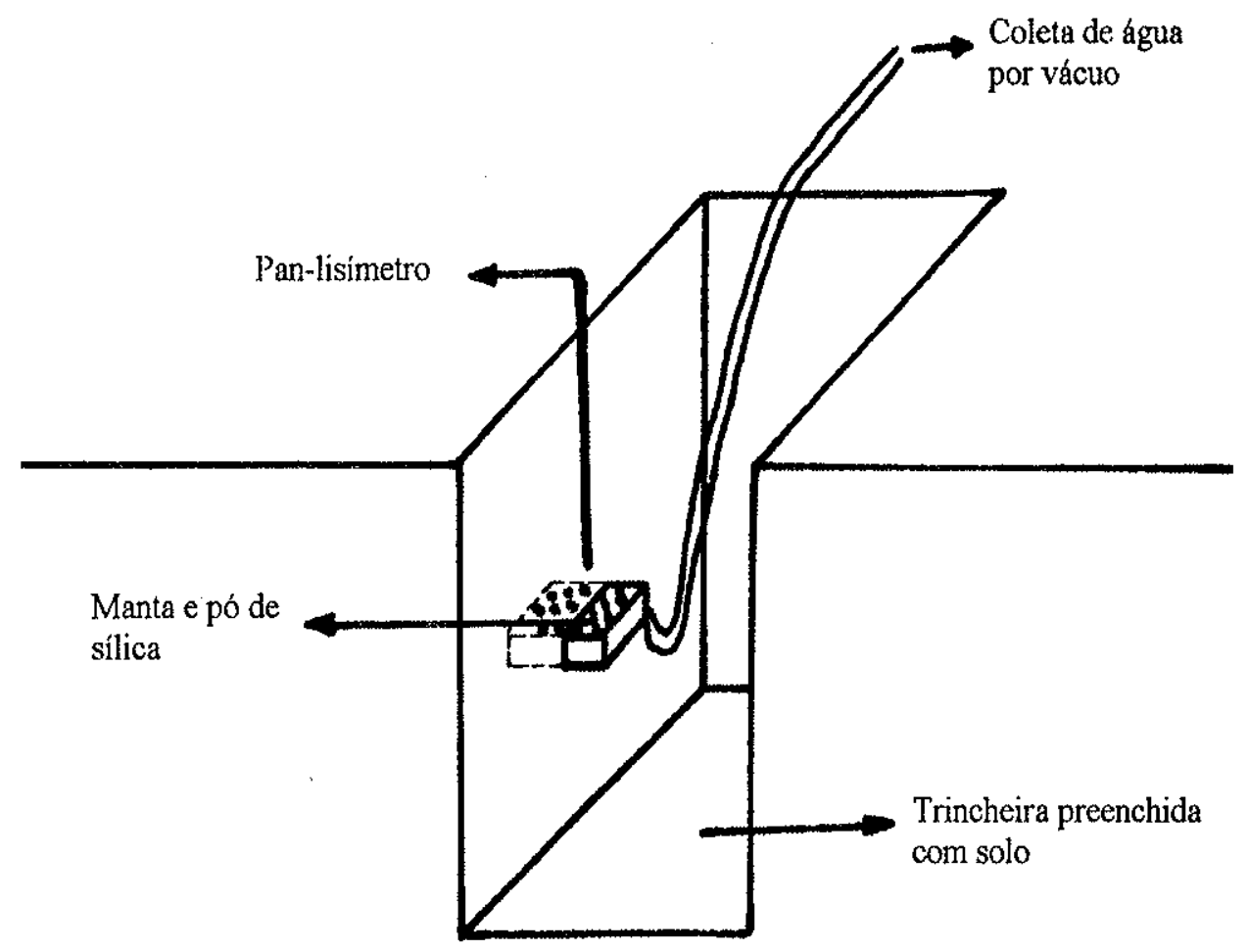

Figura 3.8 - Esquema de instalação do pan-lisímetro

\section{5- Monitoramento da zona saturada}

\subsection{1- Poços de monitoramento e piezômetros}

Conforme descreve FETTER (1993), "antes de projetar um poço de monitoramento, é necessário determinar qual será o seu uso. Algumas utilidades dos poços de monitoramento podem ser citados a seguir:

- medir a elevação do lençol freático;

- medir o nível d'água potenciométrico dentro de um aqüífero;

- coletar amostras de água para análises químicas;

- coletar amostra de uma fase líquida não aquosa menos densa que a água;

- coletar amostra de uma fase líquida não aquosa mais densa que a água;

- realizar testes de condutividade hidráulica ou permeabilidade do aqüífero ou aquiclude;

- prover acesso para instrumentos geofísicos;

- coletar amostras de gás do solo ". 
"Em função destes propósitos e de fatores geológico e hidrogeológicos e das características dos contaminantes, os seguintes fatores devem ser incluídos no projeto de um poço de monitoramento:

- tipo de material do tubo;

- diâmetro do tubo;

- comprimento do tubo;

- profundidade do poço;

- locação e comprimento do filtro do poço;

- diâmetro do filtro do poço;

- tipo de material do filtro do poço;

- tamanho das aberturas do filtro do poço;

- se um pré-filtro artificial é necessário;

- gradação do material do pré-filtro;

- método de instalação do poço e filtro;

- material utilizado para selar o espaço anelar entre o tubo e a parede da sondagem;

- proteção externa.

Os poços de monitoramento podem ser instalados por vários métodos de perfuração como o trado oco, rotativa com lama, rotativa com ar e percursão. $O$ equipamento usado para a instalação do poço de monitoramento e o material usado no poço devem ser descontaminados. Uma vez instalado, o poço necessita ser desenvolvido, para remover material fino da área fora do filtro do poço. Poços de monitoramento do lençol freático são instalados para determinar as variações de nível do lençol freático e piezômetros são usados para medir o potencial hidráulico nas formações abaixo do lençol freático. Frequentemente um poço de lençol freático e vários piezômetros são instalados no mesmo local para formar um conjunto de poços para obter-se medidas à diferentes profundidades" (FETTER, 1993).

Medidas de nível d'água são obtidas em piezômetros ou poços de monitoramento. A maioria dos sistemas de monitoramento da qualidade das águas subterrâneas são compostos por poços e por piezômetros. Piezômetros são instalações de monitoramento cujo objetivo primordial é a medida de potencial hidráulico. Geralmente, estas instalações são relativamente pequenas (menor que 1 polegada de diâmetro) ou em alguma aplicação pode constituir-se apenas de tubos ou fios elétricos conectados a transdutores de pressão ou elétricos.

Os piezômetros não são tipicamente projetados para obter amostras para análises químicas, embora o termo piezômetro tenha sido aplicado para equipamentos modificados para coletar amostras de águas subterrâneas (MASLANSKY et al., 1987 in DALTON et al., 1991). Os poços 
de monitoramento diferem dos piezômetros, pois eles são tipicamente projetados para obtenção de amostras de águas subterrâneas (DALTON et al., 1991).

\subsection{2- Locação e número de poços de monitoramento e piezômetros}

"O projeto de sistemas de monitoramento das águas subterrâneas deve considerar requerimentos para amostragem de dados de potencial hidráulico (níveis d'água) e amostragem de água subterrânea. Em alguns casos ambas as necessidades podem ser acomodadas sem a instalação de sistemas separados. Entretanto, para coletar dados de nível d'água, alguns requerimentos podem não ser consistentes com os requerimentos para coletar amostras de água subterrâneas. Por exemplo, poços adicionais podem ser requeridos para acessar completamente a configuração de um lençol freático ou superficie potenciométrica, além dos que devem ser requeridos para coletar amostras de águas subterrâneas. Inversamente, o projeto de poços para coletar amostras de água subterrâneas pode diferir dos poços usados somente para coletar dados de nível d'água" (DALTON et al., 1991).

Fatores geológicos e hidrológicos devem ser conhecidos em detalhe para projetar apropriadamente em sistema de monitoramento das águas subterrâneas. Estes dados são obtidos através de investigação em campo utilizando-se métodos diretos (sondagens a trado ou mecânicas) e indiretos de investigação (métodos geofísicos).

Para a determinação da geologia do local devem ser determinadas a litologia, textura, estruturas, mineralogia e a distribuição dos materiais inconsolidados e/ou consolidados. Os elementos hidrogeológico que devem ser considerados no projeto de um sistema de monitoramento das águas subterrâneas são: locação espacial dos aquiferos e aquicludes e suas propriedades hidráulicas (condutividade hidráulica horizontal e vertical, profundidade do lençol freático e suas variações sazonais, porosidade efetiva e gradientes hidráulicos, por exemplo).

A condutividade hidráulica saturada pode ser determinada em laboratório utilizando-se dois métodos: permeâmetro de carga constante e permeâmetro de carga variável. $O$ primeiro é geralmente aplicável para materiais com condutividade hidráulica variando de $10^{-3}$ a $10^{-1}$ $\mathrm{cm} / \mathrm{seg}$ e o segundo para materiais com condutividade hidráulica variando de $10^{-7}$ a $10^{-3} \mathrm{~cm} / \mathrm{seg}$. Ela também pode ser estimada utilizando-se da distribuição granulométrica (HAZEN, 1911 in SEVEE, 1991; Tood, 1959). No campo, a condutividade hidráulica saturada pode ser determinada através de testes de bombeamento e "slug tests". Os gradientes hidráulicos podem ser obtidos dos mapas potenciométricos confeccionados com os dados de potencial hidráulico. A porosidade efetiva pode ser estimada determinando-se a vazão específica do material, considerando-se seus valores semelhantes (CLEARY, 1989). 
"Dạdos de monitoramento do nível d'água são geralmente coletados durante duas fases do programa de monitoramento. A fase inicial é realizada quando o local a ser monitorado está sendo caracterizado para prover dados para o projeto do sistema de monitoramento. A segunda fase é quando dados de nível d'água estão sendo coletados como parte do programa de monitoramento para acessar se mudanças na direção de fluxo estão ocorrendo e para confirmar que os poços de monitoramento estão propriamente locados. Estes dados também fornece uma base para determinar a causa destas mudanças para verificar se é necessário mudanças no sistema de monitoramento" (DALTON et al., 1991).

Estes dados são utilizados para locar os poços de montante e de jusante em relação a posição do local em questão e o fluxo das águas subterrâneas. Estas informações podem ser obtidas utilizando-se informações disponiveis e investigações preliminares no local (SARA, 1991).

O número de poços de monitoramento, assim como a locação e comprimento dos filtros é função do tamanho e características da área a ser estudada, das características dos contaminantes potenciais e da complexidade geológica e hidrogeológica do local. Segundo USEPA (1986b) devem ser instalados um ou mais poços a montante do local onde é possível coletar amostras representativas das condições naturais de qualidade, não afetadas pela fonte potencial a ser monitorada.

"Os poços de jusante devem proporcionar a concentração e localização de uma provável ou existente pluma de contaminação. No primeiro caso os poços devem ser locados o mais próximo possível da fonte potencial para proporcionar deteç̧ão rápida da contaminação. No caso de uma pluma existente, os poços devem ser locados de maneira que sua distribuição espacial seja determinada. Os métodos geofísicos, como os métodos da eletrorresistividade e eletromagnéticos, são muito utilizados e apresentam bons resultados para a locação de poços de monitoramento em áreas já contaminadas por substância inorgânicas" (USEPA, 1986b).

$\mathrm{Na}$ figura 3.9 são apresentados esquemas de instalação de poços de monitoramento ou piezômetros multiniveis.

\subsection{3- Amostragem}

Existe um grande número de sistemas de amostragem que tem sido desenvolvidos para retirar amostras de água de poços de monitoramento. Podem ser citados "bailers", "bladder pumps", "piston pumps", amostradores tipo seringa e bombas peristálticas. A eficiência destes sistemas de coletar uma amostra varia com o projeto, técnica usada, e o material com o qual foi construído. 
Antes de amostrar um poço, é necessário esgota-lo para remover água estagnada do tubo (FETTER, 1993).

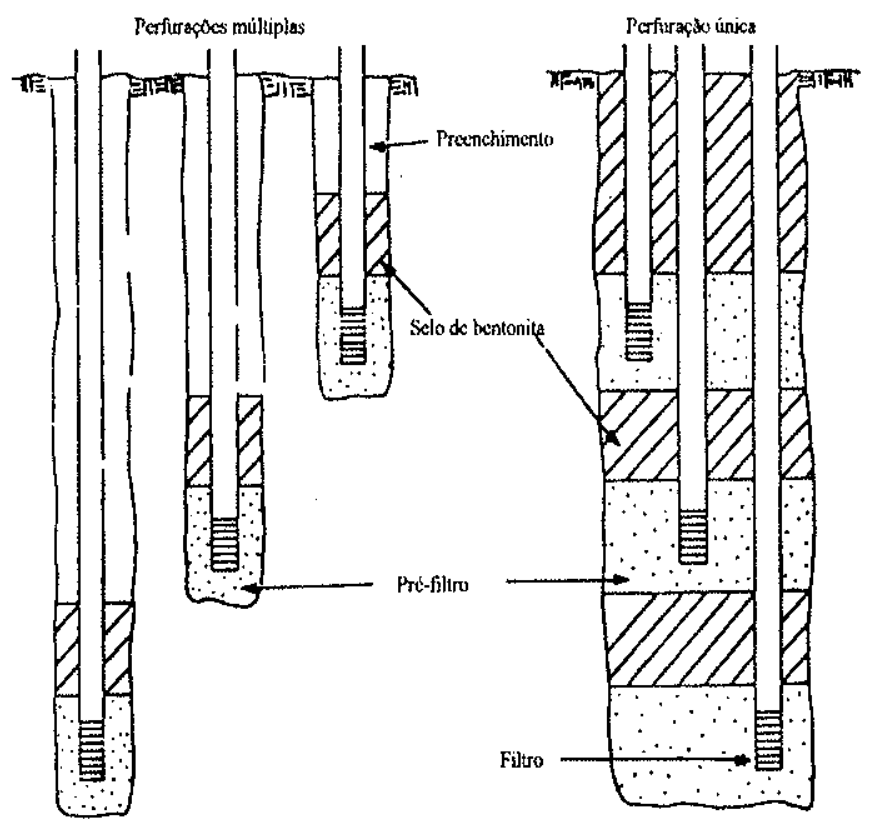

Figura 3.9 - Esquema de construção e instalação de multiníveis (USEPA, 1987)

\section{6- Geologia Regional}

"O Estado de São Paulo faz parte da plataforma sul-americana e o seu registro geológico é bastante extenso, cobrindo o intervalo do Arqueano ao Holoceno. Na configuração da superfície do Estado de São Paulo, distinguem-se: uma porção do Escudo Atlântico, com restritas coberturas sedimentares e pequenas intrusões jurássico-paleocênicas e uma porção da cobertura da plataforma, representada pela sequência vulcânica da Bacia do Paraná, com importantes intrusões jurássico-cretáceas.

A Bacia do Paraná é uma área de sedimentação fanerozóica com cerca de $1.750 .000 \mathrm{Km}^{2}$, dos quais $1.150 .000 \mathrm{Km}^{2}$ pertencem ao território brasileiro. A maior parte do Estado de São Paulo acha-se incluída nesta bacia intracratônica, que em sua zona mais deprimida acumulou cerca de $5.000 \mathrm{~m}$ de espessura de sedimentos, lavas e sills" (CAMPOS, 1993).

O Grupo São Bento da Bacia do Paraná de idade triássico-cretácea é constituído por três formações: Formação Pirambóia (arenitos de origem flúvio-lacustre), Formação Botucatu 
(arenitos de origem eólica) e Formação Serra Geral (derrames basálticos e diabásios) (DAEE, 1974).

"A Formação Serra Geral é representada por rochas de composição basáltica (toleítica) originada pela atividade magmática fissural, concomitante a processos magmáticos subterrâneos que deram origem aos sills, diques e lacólitos. Intercalados nestas rochas, ou mesmo recobrindo-as, podem ocorrer camadas sedimentares da Formação Botucatu.

A·Formação Botucatu é uma unidade genética de ambiente desértico constituído por arenitos de granulação fina a média, subsidiariamente com frações finas e grosseiras. $O$ teor de argila e silte é ao redor de 5\%. Na Bacia Hidrográfica do Rio Pardo sua espessura média é de $60 \mathrm{~m}$, aflorando a leste de Ribeirão Preto e mergulhando a oeste subjacente aos basaltos, iniciando condições confinantes" (SINELLI, 1987).

"A Formação Botucatu é constituída por um pacote de arenito de granulação fina a média dominante, com estratificação cruzada de grande a médio porte, muito friáveis ou silicificados apresentando na parte basal corpos de arenitos conglomeráticos. A espessura da Formação Botucatu apresenta localmente variações consideráveis, pelo fato de seu contato superior não ser uma superfície regular e por apresentar frequentemente interdigitamentos com basaltos. De um modo geral, porém, a Formação estende-se como um lençol, ora mais, ora menos espesso. Em Ribeirão Preto tem espessura de 90 a 100 m" (DAEE, 1974).

"A Formação Pirambóia é uma unidade genética de ambiente fluvial, constituída por arenitos de granulação fina a média, ocorrendo na sua parte basal arenitos conglomeráticos. $\mathrm{O}$ teor de silte $\mathrm{e}$ argila é da ordem de $20 \%$. A espessura máxima desta Formação na Bacia do Rio Pardo é da ordem de 160 m" (SINELLI, 1987).

"A Formação Pirambóia data do Trássico-Jurássico, tendo sido depositados em ambiente fluvial. São arenitos de granulação variável, dominantemente fina a média, muito a pouco argilosos, consistentes, com variação de litologia na vertical, intercalando finas camadas de lamitos argilosos, exibindo estratificação cruzada planar e acanalada e plano-paralela. Na área de Serrana e Serra Azul sua espessura é de cerca de 100 m" (SOARES, 1973 in DAEE, 1974).

Na Região Administrativa 6 do Estado de São Paulo, Região de Ribeirão Preto, ocorrem também sedimentos cenozóicos em manchas descontínuas, associados à interflúvios e espigões. Deve-se destacar que as camadas sedimentares inferiores à Formação Serra Geral sofreram espessas intrusões de diabásio. O Nordeste da região (flanco da Bacia do Paraná) apresenta grande quantidade dessas rochas intrusivas (DAEE, 1974). 
"Estas rochas intrusivas se fizeram em areias do deserto Botucatu, portanto no seio de sedimentos completamente inconsolidados, sem nenhuma plasticidade ou resistência mecânica aos esforços causados pela injeção de magma. Prova desta afirmação é a ausência de rupturas (falhas) típicas das encaixantes ante à entrada de qualquer material ígneo intrusivo. Na verdade, as areias do deserto Botucatu se deformaram e foram envolvidas pela chegada do magma, interdigitando-se e soerguendo grandes pacotes sem destruir-lhe as estruturas. $\mathrm{Na}$ região de Ribeirão Preto, em vista do baixo nível topográfico, relativamente às cotas atingidas pelas áreas vizinhas próximas, como Cravinhos e Brodosqui, não se deve encontrar basaltos, mas, tão somente diabásios. Os basaltos, se existirem, deveriam se localizar em níveis acima dos $900 \mathrm{~m} "$ (DAVINO et al., 1982).

\section{7- Hidrogeologia e Hidrogeoquímica Regionais}

"O reconhecimento hidrogeológico básico do Estado de São Paulo foi executado pelo Departamento de Águas e Energia Elétrica - DAEE, através do Projeto Águas Subterrâneas, iniciado em 1972 e concluído em 1982. Este projeto recobriu as 11 Regiões Administrativas do Estado, iniciando-se na Região Administrativa 6, Ribeirão Preto. Estes estudos por região administrativas constituem um diagnóstico das unidades aqüíferas do Estado, das condições de explotação das águas subterrâneas e de sua utilização para diversos fins. Este projeto permitiu a acumulação de um grande acervo de dados e informações geológicas, incluindo dados de mais de 10.000 poços tubulares e 1.600 análise químicas de água. Este conjunto de informações necessita de um trabalho de atualização, integração e síntese cartográfica, subsídio básico para o planejamento e gestão dos recursos hídricos" (CAMPOS, 1993).

CAMPOS (1993), com o intuito de avaliar a evolução do conhecimento sobre a hidrogeoquímica no Estado de São Paulo elaborou um quadro cronológico dos trabalhos disponíveis. Deste quadro o autor destaca vários trabalhos realizados sobre a hidroquímica dos sistemas aqüíferos Botucatu e Serra Geral.

"O aqüífero Botucatu é constituído pelas Formações Pirambóia e Botucatu, que possuem características hidrogeológicas semelhantes, podendo serem tratadas como um único sistema aquífero, chamado de Sistema Aqüífero Botucatu. Na região de Ribeirão Preto localiza-se grande parte da área aflorante do Sistema Aqüífero Botucatu (zona de recarga regional) constituíndo-se na porção mais vunerável à poluição" (ROCHA, 1986).

Segundo KIMMELMANN et al. (1990) "os resultados isotópicos e hidroquímicos obtidos em trabalhos realizados sobre o Sistema Aqüifero Botucatu-Pirambóia indicam que as suas águas subterrâneas originam-se principalmente da infiltração nas zonas de afloramento e sua evolução 
química é determinada pelo grau de confinamento, direções de fluxo e tempo de residência. Devido a excelente qualidade da água cresce o número de poços instalados e consequentemente o conhecimento hidrogeológico e hidrogeoquímico deste importante sistema aqüifero", que é responsável pelo abastecimento de água de grandes cidades do Estado de São Paulo, como por exemplo a Cidade de Ribeirão Preto, que é totalmente abastecida por águas subterrâneas, principalmente pelo Aqüífero Botucatu.

"O sistema aqüífero Botucatu é o principal reservatório de água subterrânea do Estado de São Paulo. Em toda a sua área aflorante $\left(16.000 \mathrm{Km}^{2}\right.$, com espessura máxima de $\left.250 \mathrm{~m}\right)$ e na região onde ocorre confinado pelos derrames de basaltos da Formação Serra Geral $\left(138.000 \mathrm{Km}^{2} \mathrm{com}\right.$ $500 \mathrm{~m}$ de espessura máxima), este aqüífero é constituído por arenitos eólicos e fluviais bem selecionados, com espessura média de $300 \mathrm{~m}$; mergulha para noroeste sob os basaltos e atinge profundidades de até $1.500 \mathrm{~m}$. O confinamento do Sistema Aqüifero Botucatu caracteriza condição de artesianismo em $90 \%$ da área. Atualmente é explotado por cerca de 1000 poços tubulares, a maioria localizada na área aflorante e na porção adjacente, onde as espessuras dos basaltos confinantes são menores. Existem dezenas de poços com profundidades superiores a $1000 \mathrm{~m}$, cujas vazões variam de $300 \mathrm{a} 600 \mathrm{~m}^{3} / \mathrm{h}$; as permeabilidades aparentes são da ordem de 0,2 a 4,0 (porção livre) e de 0,5 a 4,6 m/d (porção confinada)" (CAMPOS, 1993).

"O Sistema Aqüífero Serra Geral apresenta-se em derrames sucessivos de lavas, superpostos, onde os sistemas de fraturamento (zonas aquíferas) estão relacionados tanto a esforços tectônicos, gerando fraturas subverticais, como a processos de resfriamento que originam discontinuidades subhorizontais. É explotado atualmente por cerca de 1.300 poços tubulares, a maioria com profundidade de 100 a $150 \mathrm{~m}$, com vazões variáveis, sendo que os poços situados junto a lineamentos estruturais ou fraturas, apresentam vazões de 10 a $100 \mathrm{~m}^{3} / \mathrm{h}$.

O Sistema Aqüífero Diabásio, constituído de rochas intrusivas básicas (diabásios), tem extensão limitada, fissurado, descontínuo, com área de afloramento de cerca de $3.300 \mathrm{Km}^{2}$, pode apresentar vazões da ordem de 5 a $30 \mathrm{~m}^{3} / \mathrm{h}$, para poços com até $150 \mathrm{~m}$ de profundidade" (CAMPOS, 1993).

"O armazenamento de água subterrânea nos diabásios é condicionado ao seu potencial de fissuras. As vazões médias dos poços perfurados nesta Formação, na Bacia Hidrográfica do Rio Pardo, dão valores da ordem de $20 \mathrm{~m}^{3} / \mathrm{h}$ e em alguns casos chega a $90 \mathrm{~m}^{3} / \mathrm{h}$. A potencialidade deste aquífero, bem como, as características hidrodinâmicas são de difícil avaliação tendo em vista o seu interrelacionamento com os aqüiferos das Formações Botucatu e Pirambóia" (SINELLI, 1987). 
"O Sistema Aqüífero Botucatu, na sua parte livre apresenta temperaturas que variam de 22 a $27^{\circ} \mathrm{C}$, pH de 5,4 a 9,27 e $66 \%$ das amostras com teores salinos inferiores a $50 \mathrm{mg} / 1$. Predominam águas bicarbonatadas cálcicas (44\%) seguidas das bicarbonatadas magnesianas. Na sua parte confinada o sistema aqüífero Botucatu apresenta temperaturas que variam de 22 a $58^{\circ} \mathrm{C}$, pH de 6,3 a 9,8 e $96 \%$ das águas com teores salinos na faixa de 50 a $500 \mathrm{mg} / \mathrm{l}$. As águas bicarbonatadas cálcicas (44\%) e bicarbonatadas sódicas (36\%) perfazem $80 \%$ dos tipos químicos encontrados. Em termos regionais as águas do aqüífero Botucatu obedecem uma evolução hidrogeoquímica clássica dos íons cloreto e sódio acompanhados de um enriquecimento de teor salino no sentido oeste do Estado de São Paulo" (CAMPOS, 1993).

A área de estudo selecionada neste estudo encontra-se localizada na Bacia Hidrográfica do Rio Pardo que abrange parte da $6^{a}$ Região Administrativa do Estado de São Paulo. Todas as cidades situadas nesta bacia apresentam como fonte principal de abastecimento as águas subterrâneas extraídas dos aqüíferos Serra Geral, Botucatu e Pirambóia (SINELLl, 1987).

"O modelo hidrogeológico na bacia é complexo em virtude dos fluxos verticais existentes entre os aluviões, Formação Serra Geral, Formação Botucatu e Formação Pirambóia. Os fluxos horizontais, dominantes, são perturbados pela enorme quantidade de estruturas intrusivas, diabásios, que cortam as Foramções Botucatu e Pirambóia, principais armazenadores da bacia" (SINELLI, 1987).

"Aluviões são encontradas em extensas planícies de inundação associadas ao Rio Pardo e afluentes. São depósitos formados por cascalhos e areias recobertas por camadas de argila. A maior parte do material que constituem estes depósitos foram originados dos arenitos da Formação Botucatu e Pirambóia, apresentando ainda contribuição de basaltos e diabásios da Formação Serra Geral. A espessura total destes depósitos atinge cerca de $6 \mathrm{~m}$. As argilas superficiais não ultrapassam $3 \mathrm{~m}$ de espessura. A associação areia e cascalho apresenta elevada porosidade e permeabilidade e a água é pouco mineralizada. Trata-se de um aquífero de alto potencial e baixo custo de explotação.

Os poços perfurados exclusivamente na Formação Pirambóia, situados a sudeste da Bacia, apresentam vazões da ordem de $35 \mathrm{~m}^{3} / \mathrm{h}$, vazão específica da ordem de $6,0 \mathrm{~m}^{3} / \mathrm{h} / \mathrm{m}$. O coeficiente de armazenamento é de $1,5 \times 10^{-2}$ e a transmissividade de $6,0 \mathrm{~m}^{2} / \mathrm{h}$. Na situação em que o Aqüífero Pirambóia está confinado e o Aqüífero Botucatu está livre, na região de Serrana, Serra Azul as principais características encontradas são: vazão média de $60 \mathrm{~m}^{3} / \mathrm{h}$ com amplitude máxima de $120 \mathrm{~m}^{3} / \mathrm{h}$, transmissividade de $8,4 \mathrm{~m}^{2} / \mathrm{h}$ e coeficiente de armazenamento de $2 \times 10^{-2}$. Do ponto de vista químico suas águas apresentam excelente qualidade e como característica química apresentam a sequência catiônica: $\mathrm{MMg}^{+2}>\mathrm{rCa}^{+2}>\mathrm{rNa}^{+1}>\mathrm{rK}{ }^{+1}$. 
O sistema aquífero Botucatu Pirambóia, nas regiões de Serrana e Serra Azul, apresenta uma vazão especifica da ordem de $10 \mathrm{~m}^{3} / \mathrm{h} / \mathrm{m}$, permeabilidade e uma taxa de infiltração da ordem de $19 \%$ da precipitação pluviométrica indicando tratar-se de aquífero com alta vulnerabilidade à poluição, agravado pelo fato desta região estar ocupada na sua totalidade pelo plantio da cana de açúcar e possuir alta densidade de usinas açucareiras. A recarga profunda nestas duas Formações correspondem a $4,5 \%$ da precipitação pluviométrica equivalentes a $128 \times 10^{6} \mathrm{~m}^{3} /$ ano. Quimicamente são águas de excelente qualidade e a seqüência catiônica é representada por: $\mathrm{rCa}^{+2}>\mathrm{rMg}^{+2}>\mathrm{rK}^{+1}>\mathrm{rNa}^{+1}$.

Verifica-se um aumento na concentração do íon cálcio no sentido da direção do fluxo subterrâneo, e uma diminuição do teor de magnésio, havendo uma evolução do íon sódio. Praticamente o único ânion presente é o $\mathrm{HCO}_{3}^{-1}$ cuja concentração aumenta de 5 a 20 vezes no sentido oeste. Análises de poços profundos foram realizadas na Bacia Hidrográfica do Rio Pardo demostraram que a temperatura é praticamente constante. A condutividade elétrica é menor na zona de recarga dos Aqüíferos Botucatu e Pirambóia. Existe um aumento das concentrações de cátions no sentido leste-oeste, ou seja da região do aqüífero livre para o confinado.

Os valores médios obtidos em laboratório para arenitos das Formações Botucatu e Pirambóia, paralelos à estratificação, forneceram o resultado de: condutividade hidráulica, $\mathrm{K}$, igual a $1.8 \times 10^{-4} \mathrm{~cm} / \mathrm{s}$ e $\mathrm{n}$, porosidade eficaz, igual a $0.15^{\prime \prime}$ (SINELLI, 1987). 


\section{4- METODOLOGIA}

A metodologia utilizada neste estudo compreendeu as seguintes fases:

- seleção de uma área de estudo adequada,

- caracterização geológica e hidrogeológica desta área,

- implantação da rede de equipamentos de monitoramento das zonas não saturada e saturada,

- aplicação da vinhaça e execução do monitoramento das zonas não saturada e saturada,

- interpretação dos dados coletados em campo utilizando-se várias técnicas selecionadas a partir da revisão bibliográfica apresentada.

\section{1- Seleção da área de estudo}

A área de estudo foi selecionada utilizando-se os seguintes fatores, julgados adequados para tornar o estudo representativo de situações reais:

- situar-se em região de afloramento da Formação Botucatu, pois nesta encontra-se a área de recarga regional do Sistema Aqüifero Botucatu;

- presença de lençol freático alto, que facilita as operações de perfuração, possibilita a obtenção de resultados mais rapidamente e constitui-se na situação de maior vulnerabilidade do aquífero freático local;

- existência de um meio poroso homogêneo, o que facilita as interpretações dos resultados;

- existência de área de descarga local, o que permite a identificação inicial aproximada de padrões de fluxo das águas subterrâneas locais;

- ausência de fontes de poluição a montante da área;

- estar ocupada pelo plantio de cana sem que tenham ocorrido alterações significativas na qualidade das águas das zonas não saturada e saturada;

- situar-se na região de Ribeirão Preto, por esta constituir-se uma das principais regiões produtoras de cana-de-açúcar do Estado de São Paulo.

O Mapa Geológico do Estado de São Paulo (DAEE-UNESP, 1982), escala 1:250.000 e os Mapas Topográficos do IBGE, escala 1:50.000 foram utilizados para orientação nos trabalhos de campo, visando a seleção da área de estudo.

Nas áreas visitadas foram realizadas sondagens a trado manual e observações em afloramentos, visando selecionar aquela com um maior número de características favoráveis, atendendo aos fatores estabelecidos. 
A área de estudo selecionada localiza-se no Município de Serrana-SP nas coordenadas $21007^{\prime}$, de latitude de sul, e 47034' de longitude ceste. A sua localização é apresentada na figura 4.1.

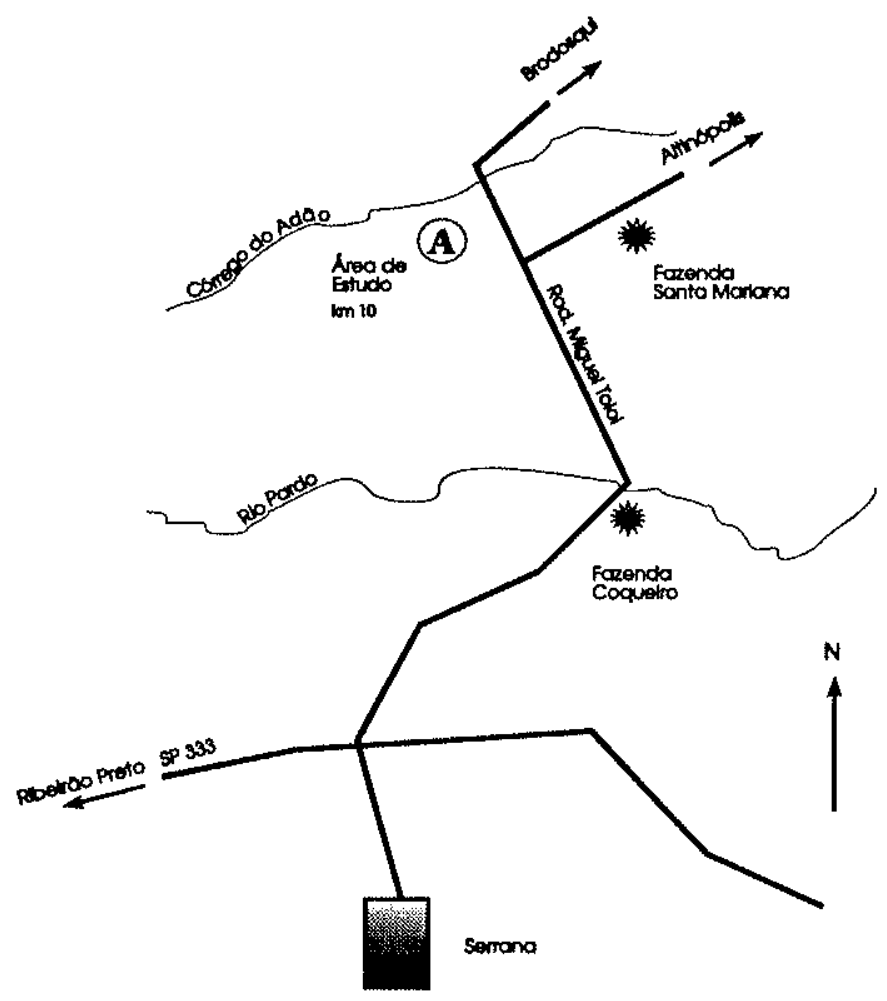

Figura 4.1 - Localização da área de estudo

O clima da região, segundo a classificação de Koeppen, enquadra-se entre o Grupo A, dos climas tropicais quentes e o Grupo $\mathrm{C}$, dos climas mesotérmicos, com características bem definidas no inverno (tempo seco) e verão (tempo chuvoso) (DAEE, 1974). A precipitação média anual é de $1467 \mathrm{~mm}$ (SINELLI, 1987).

A área de estudo selecionada possui $1024 \mathrm{~m}^{2}(32 \times 32 \mathrm{~m})$, que está localizada em uma área ocupada exclusivamente por cana-de-açúcar. Neste local o relêvo é plano, apresentando leve inclinação do terreno.

Durante a fase de seleção da área de estudo, realizada em setembro de 1987, o nível da água subterrânea, obtidos a partir de sondagens, encontrava-se a $2,5 \mathrm{~m}$ de profundidade. Possivelmente a qualidade destas águas encontrava-se praticamente em estado natural em função das características observadas no local e ao fato de que a área, na ocasião, havia sido plantada com cana recentemente, tendo recebido uma única aplicação de vinhaça um ano antes, aproximadamente, de ser iniciado este estudo. A área selecionada para a implantação do estudo situa-se, aproximadamente, a $300 \mathrm{~m}$ de distância de uma área de descarga local (Ribeirão do Adão). 


\section{2- Caracterização geológica e hidrogeológica local}

Na figura 4.2 é apresentado um esquema geral da área de estudo, onde são apresentados o posicionamento dos equipamentos de monitoramento instalados, a locação das trincheiras escavadas para coleta de amostras indeformadas, assim como o posicionamento em planta dos locais onde foram executadas medidas geofísicas.

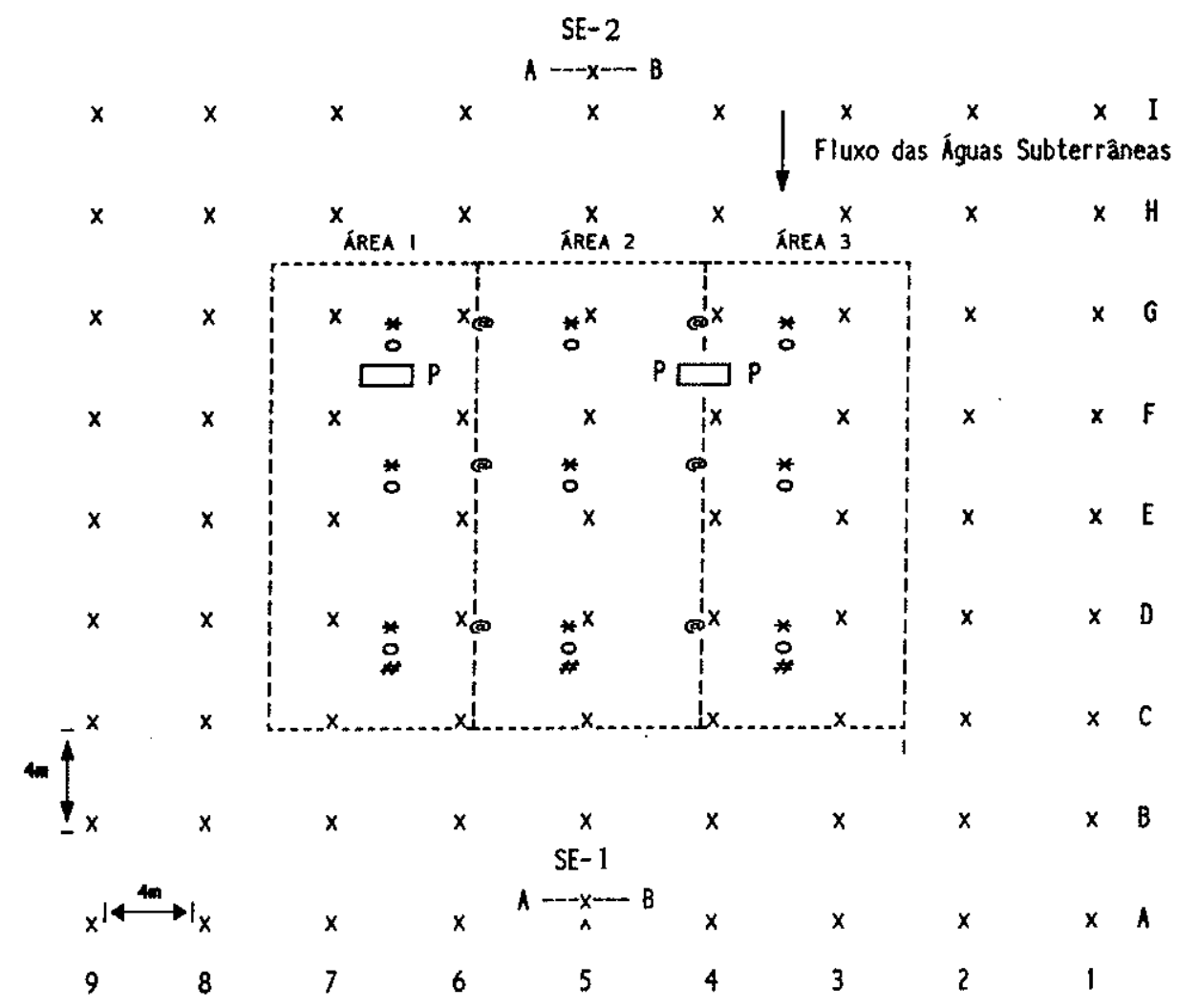

\footnotetext{
LEGENDA

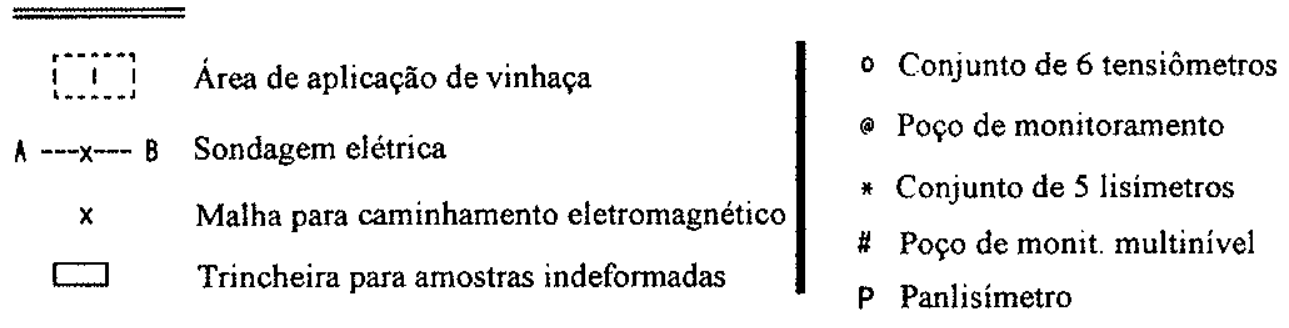

Figura 4.2 - Esquema da área de estudo 
Em março de 1988 foram realizadas 6 sondagens a trado e retiradas amostras de solo e/ou sedimentos para análises granulométricas, cujos resultados são apresentados na tabela 4.1.

Tabela 4.1 - Análises granulométricas

\begin{tabular}{|c|c|c|c|c|c|c|}
\hline $\begin{array}{c}\text { PROF. } \\
(\mathrm{cm})\end{array}$ & $\begin{array}{c}\text { AREIA } \\
\text { GROSSA }(\%)\end{array}$ & $\begin{array}{c}\text { AREIA } \\
\text { FINA }(\%)\end{array}$ & $\begin{array}{c}\text { AREIA } \\
(\%)\end{array}$ & $\begin{array}{c}\text { SILTE } \\
(\%)\end{array}$ & $\begin{array}{c}\text { ARGILA } \\
(\%)\end{array}$ & $\begin{array}{c}\text { ARGILA } \\
(\text { H2O)(\%) }\end{array}$ \\
\hline $0-30$ & 33,6 & 56,0 & 89,6 & 1,4 & 9,0 & 5,1 \\
\hline $30-60$ & 33,9 & 55,9 & 89,8 & 1,0 & 9,2 & 5,8 \\
\hline $60-90$ & 34,3 & 52,2 & 86,5 & 4,8 & 8,7 & 7,1 \\
\hline $90-120$ & 32,4 & 55,6 & 88,0 & 1,6 & 10,4 & 7,2 \\
\hline $120-150$ & 31,0 & 56,4 & 87,4 & 1,1 & 11,5 & 8,8 \\
\hline $150-180$ & 28,2 & 58,7 & 86,9 & 2,1 & 11,0 & 1,4 \\
\hline $180-210$ & 27,8 & 58,1 & 85,9 & 4,0 & 10,1 & 4,6 \\
\hline $210-240$ & 29,2 & 57,9 & 87,1 & 2,9 & 10,0 & 6,8 \\
\hline $240-270$ & 28,5 & 56,0 & 84,5 & 5,8 & 9,7 & 5,6 \\
\hline $270-300$ & 29,0 & 54,8 & 83,8 & 4,9 & 11,3 & 3,2 \\
\hline $390-420$ & 28,2 & 56,6 & 84,8 & 3,0 & 12,2 & 2,3 \\
\hline $420-450$ & 31,7 & 56,9 & 88,6 & 1,6 & 9,8 & 2,3 \\
\hline
\end{tabular}

Estes resultados demonstram que o material pedológico-geológico do local, constituído predominantemente por quartzo, derivado da Formação Botucatu, não apresenta variações significativas na sua granulometria, podendo-se admitir como uniformes suas características hidrogeológicas.

\subsection{1 - Caracterização da zona saturada}

Nos furos das sondagens realizadas foram instalados 6 poços de monitoramento com filtro longo ( $2 \mathrm{~m})$, construídos e instalados conforme esquema da figura 4.3. Na tabela 4.2 são apresentadas as características destes poços e a localização em planta destes pode ser observada na figura 4.2.

Estes poços foram utilizados para a realização de observações da variação do nível d'água e para coleta de dados de potencial hidráulico para a confecção de mapas potenciométricos, utilizados para a representação dos sentidos de fluxo das águas subterrâneas na área de estudo. Estes poços proporcionaram também a coleta de amostras de água para análises físico químicas. Em maio de 1988 foram feitas medidas de condutividade elétrica das águas destes poços, sendo encontrados baixos valores $(30 \mu \mathrm{s} / \mathrm{cm})$, indicando baixas concentrações de íons em solução.

O potencial hidráulico $(\mathrm{H})$ no poço é calculado através da expressão:

$\mathrm{H}=\mathrm{C}+\mathrm{h}-\mathrm{NA}$ 
onde $\mathrm{C}$ é a cota topográfica da superfície do terreno, h é a altura do tubo acima da superfície do terreno e NA é o valor do nível d'água medido no poço (conforme esquema da figura 4.3).

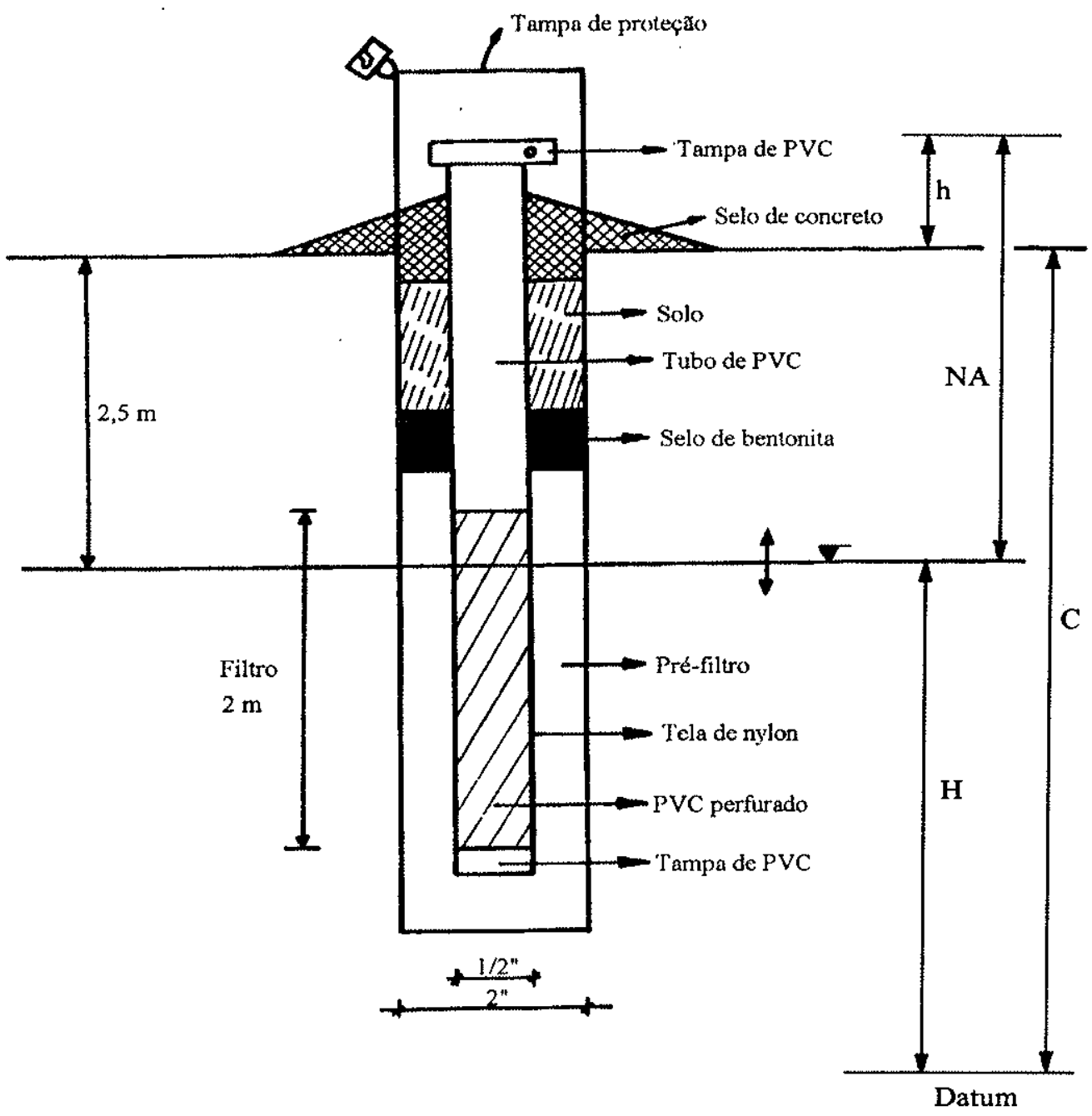

Figura 4.3 - Poço de monitoramento com filtro longo

Tabela 4.2 - Características dos poços de monitoramento com filtro longo

\begin{tabular}{|c|c|c|c|}
\hline Equipamento & $\begin{array}{c}\text { Cota } \\
(\mathrm{m})\end{array}$ & $\begin{array}{c}\mathrm{h} \\
(\mathrm{m})\end{array}$ & $\begin{array}{c}\text { Profundidade } \\
\text { instalação } \\
(\mathrm{m})\end{array}$ \\
\hline $\mathrm{P} 1$ & 527,234 & 0,170 & 4,450 \\
\hline $\mathrm{P} 2$ & 527,230 & 0,270 & 2,840 \\
\hline $\mathrm{P} 3$ & 527,600 & 0,210 & 3,950 \\
\hline $\mathrm{P} 4$ & 527,552 & 0,425 & 3,705 \\
\hline $\mathrm{P} 5$ & 527,899 & 0,330 & 3,835 \\
\hline $\mathrm{P} 6$ & 527,912 & 0,180 & 4,010 \\
\hline
\end{tabular}


A partir de medidas do potencial hidráulico foram confeccionados mapas potenciométricos que possibilitaram a visualização das variações do nível do lençol freático e o sentido de fluxo das águas subterrâneas. Na figura 4.4 são apresentados, como exemplo, os mapas potenciométricos confeccionados com as medidas de potencial hidráulico tomadas em duas datas: (a) 23/11/88 e (b) 10/04/90. As outras medições realizadas são apresentadas na tabela 4.3.

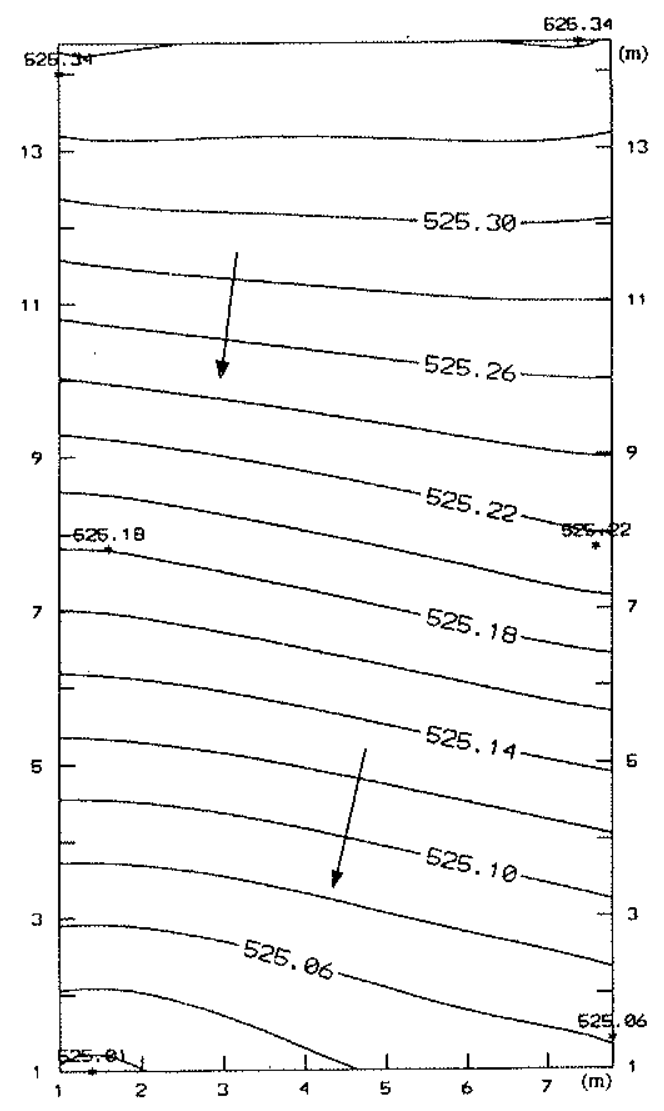

(a)

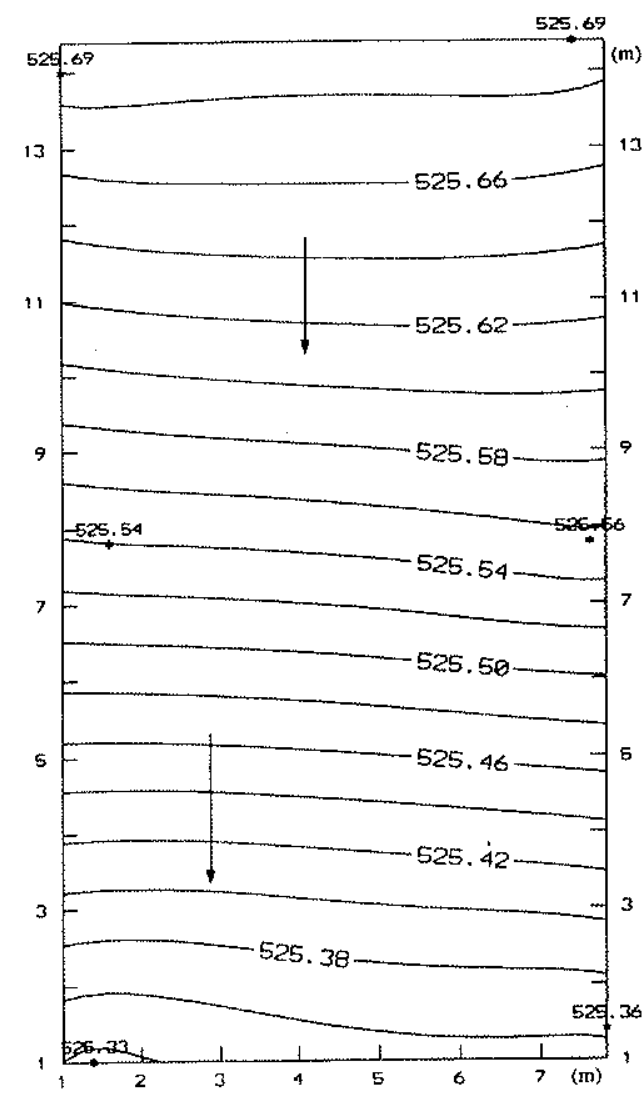

(b)

\section{Legenda}

\section{$\longrightarrow$ Sentido de fluxo da água subterrânea}

- 525.18 Linha de mesmo potencial hidráulico (m)

525.18 Potencial hidráulico no poço de

* monitoramento de filtro longo

Figura 4.4 - Mapas potenciométricos (a) e (b) 
Nos mapas potenciométricos pode-se notar que as curvas isopotenciais são equidistantes e paralelas, fato que evidencia a presença de gradiente de potencial hidráulico constante, devido provavelmente à uniformidade dos parâmetros hidrogeológicos, como a condutividade hidráulica saturada e transmissividade.

Tabela 4.3 - Medidas de nivel d'água e potencial hidráulico nos poços de monitoramento

\begin{tabular}{|c|c|c|c|c|c|c|c|}
\hline Data & & P1 & P2 & P3 & P4 & P5 & P6 \\
\hline \multirow{2}{*}{$23 / 06 / 88$} & Nível (m) & 4,23 & 2,29 & 3,25 & 2,48 & 2,54 & 2,41 \\
\cline { 2 - 8 } & $\mathrm{H}(\mathrm{m})$ & 523,174 & 525,21 & 524,56 & 525,497 & 525,689 & 525,682 \\
\hline \multirow{2}{*}{$23 / 11 / 88$} & Nível (m) & 2,39 & 2,44 & 2,63 & 2,76 & 2,89 & 2,75 \\
\cline { 2 - 8 } & $\mathrm{H}(\mathrm{m})$ & 525,014 & 525,06 & 525,18 & 525,217 & 525,339 & 525,342 \\
\hline \multirow{2}{*}{$07 / 11 / 89$} & Nível (m) & 2,62 & 2,31 & 2,83 & 2,99 & 3,09 & 2,93 \\
\cline { 2 - 8 } & $\mathrm{H}(\mathrm{m})$ & 524,784 & 525,19 & 524,98 & 524,987 & 525,139 & 525,162 \\
\hline \multirow{2}{*}{$21 / 11 / 89$} & Nível (m) & 2,23 & 2,26 & 2,43 & 2,65 & 2,76 & 2,62 \\
\cline { 2 - 8 } & $\mathrm{H}(\mathrm{m})$ & 525,174 & 525,24 & 525,38 & 525,327 & 525,469 & 525,472 \\
\hline \multirow{2}{*}{$12 / 12 / 89$} & Nível (m) & 2,17 & 2,27 & 2,37 & 2,55 & 2,69 & 2,57 \\
\cline { 2 - 8 } & $\mathrm{H}(\mathrm{m})$ & 525,234 & 525,23 & 525,44 & 525,427 & 525,539 & 525,522 \\
\hline \multirow{2}{*}{$02 / 01 / 90$} & Nível (m) & 1,91 & 1,98 & 2,14 & 2,3 & 2,44 & 2,3 \\
\cline { 2 - 8 } & $\mathrm{H}(\mathrm{m})$ & 525,494 & 525,52 & 525,67 & 525,665 & 525,789 & 525,792 \\
\hline \multirow{2}{*}{$10 / 04 / 90$} & Nível (m) & 2,07 & 2,14 & 2,27 & 2,42 & 2,54 & 2,4 \\
\cline { 2 - 8 } & $\mathrm{H}(\mathrm{m})$ & 525,334 & 525,36 & 525,54 & 525,557 & 525,689 & 525,692 \\
\hline
\end{tabular}

\subsection{2 - Caracterização da zona não saturada}

Em trincheiras escavadas na área de estudo (figura 4.2), foram coletadas amostras indeformadas utilizadas na confecção de curvas de retenção de água. As amostras foram retiradas em triplicata nas profundidades de $20,60,100,140,180$ e $220 \mathrm{~cm}$. Estas amostras foram retiradas através da cravação de anéis de alumínio. Para a construção destas curvas foi utilizado o método modificado de Haines, para valores de pressão negativas baixas, e o método da câmara de pressão, para valores altos de pressão negativa, não sendo considerado o fenômeno da histerese. As curvas de retenção de água obtidas são apresentadas na figura 4.5 .

Pode-se observar que os formatos das curvas são bastante parecidos entre si, indicando que o material constituinte da zona não saturada é também bastante homogêneo. As curvas apresentam baixos valores de umidade residual, $\theta_{\mathrm{r}}$ (valores de umidade para pressões negativas acima de $10.000 \mathrm{~cm}$ de água) e grande variação dos valores de umidade entre o intervalo de pressão negativa de 10 a $100 \mathrm{~cm}$ de água, características típicas de material arenoso. 

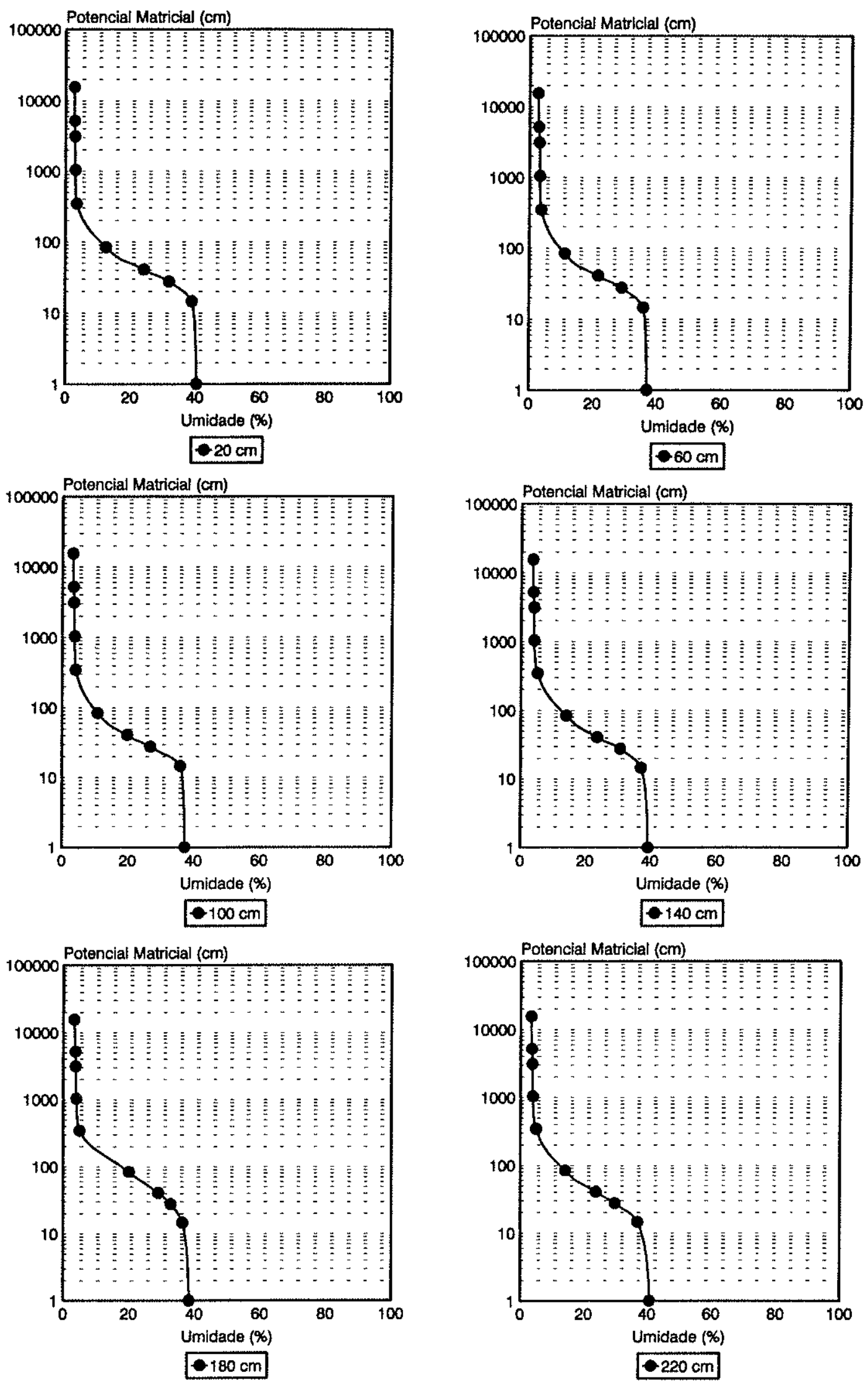

Figura 4.5 - Curvas de retenção de água 


\subsection{3- Investigações geofísicas}

Foram realizadas investigações geofísicas para auxiliar na caracterização geológica e hidrogeológica do local de estudo, utilizando-se os métodos da eletrorresistividade e eletromagnético. Foram utilizados nas sondagens elétricas, uma fonte de corrente elétrica da TECTROL e um milivoltímetro digital, e os condutivímetros EM31 e EM34-DL da Geonics, para a execucção de caminhamentos eletromagnéticos.

A localização em planta das 2 sondagens elétricas realizadas e os pontos de leituras dos aparelhos eletromagnéticos podem ser observados na figura 4.2 .

As 2 sondagens elétricas forneceram resultados semelhantes. As curvas de resistividade aparente versus $\mathrm{AB} / 2$ são apresentadas nas figuras 4.6 (SE-1) e 4.7 (SE-2), com suas respectivas interpretações, que foram realizadas utilizando-se os programas RESIST $P$, desenvolvido pela UNIVERSIDADE DE WATERLOO \& UNIVERSIDADE DE SÃO PAULO (1986) e IPES 3, desenvolvido pela Universidade de Ankara (Turquia)(BASOKUR, 1990). Os resultados obtidos nos caminhamentos eletromagnéticos (CEM) são mostrados na tabela 4.4.

Para os equipamentos eletromagnéticos as profundidades de investigação aproximadas $(\mathrm{P})$, que dependem das propriedades geoelétricas das camadas investigadas, são dadas pelas expressões:

$P=0,75 d$

para os eixos das bobinas em posição horizontal $(\mathrm{H}), \mathrm{e}$ :

$P=1,5 d$

para os eixos das bobinas em posição vertical (V), sendo d a distância entre as bobinas. Para o EM-31 d é igual a 3,75m, portanto $P$ é $2,81 \mathrm{~m}$ na posição horizontal $(E M-31 \mathrm{H})$ e $5,62 \mathrm{~m}$ na posição vertical (EM-31V).

Para o EM-34 foi utilizado o cabo de $10 \mathrm{~m}$ para serem feitas as medidas de condutividade elétrica aparente. Desta forma d é igual a $10 \mathrm{~m}$ e P, na posição horizontal (EM-34H), é 7,5m e 15m na posição vertical (EM-34V). 
Tabela 4.4 - Resultados dos caminhamentos eletromagnéticos (valores em $\mathrm{mmho} / \mathrm{m}$ )

\begin{tabular}{|c|c|c|c|c|c|c|c|c|c|}
\hline Posição & A & B & $\mathrm{C}$ & D & $\mathrm{E}$ & $\mathrm{F}$ & $\mathrm{G}$ & $\mathrm{H}$ & I \\
\hline \multicolumn{10}{|l|}{ EM-31 H } \\
\hline & & & & & & & & & \\
\hline 1 & 3,2 & - & 3 & - & 3,1 & - & 3 & - & 3,3 \\
\hline 2 & - & - & - & - & - & - & - & - & - \\
\hline 3 & 3 & - & 3,2 & - & 3,1 & - & 3,1 & - & 3,2 \\
\hline 4 & - & - & - & - & - & - & - & - & - \\
\hline 5 & 3,1 & - & 3 & - & 3 & - & 3,1 & - & 3,2 \\
\hline 6 & - & - & - & - & - & - & - & - & - \\
\hline 7 & 3 & - & 3 & - & 3 & - & 3,2 & - & 3,2 \\
\hline 8 & - & - & - & - & - & - & - & - & - \\
\hline 9 & 3 & - & 3 & - & 3 & - & 3,1 & - & 3,1 \\
\hline \multicolumn{10}{|l|}{ EM-31 V } \\
\hline 1 & 3,4 & - & 3,4 & - & 3,5 & - & 3,4 & - & 3,5 \\
\hline 2 & - & - & - & - & - & - & - & - & - \\
\hline 3 & 3,1 & - & 3,2 & - & 3,4 & - & 3,4 & - & 3,5 \\
\hline 4 & - & - & - & - & - & - & - & - & - \\
\hline 5 & 3,1 & - & 3,2 & - & 3,4 & - & 3,4 & - & 3,5 \\
\hline 6 & - & - & - & - & - & - & - & - & - \\
\hline 7 & 3,2 & - & 3,2 & - & 3,3 & - & 3,4 & - & 3,5 \\
\hline 8 & - & - & - & - & - & - & - & - & - \\
\hline 9 & 3,2 & - & 3,2 & - & 3,4 & - & 3,4 & - & 3,4 \\
\hline \multicolumn{10}{|l|}{$\mathrm{EM}-34 \mathrm{H}$} \\
\hline 1 & 0,2 & - & 0,8 & - & 0,6 & - & 0,9 & - & 0,5 \\
\hline 2 & - & - & - & - & - & - & - & - & - \\
\hline 3 & 0,35 & - & 0,8 & - & 0,55 & - & 1,3 & - & 0,7 \\
\hline 4 & - & - & - & - & - & - & - & - & - \\
\hline 5 & 0,4 & - & 1,4 & - & 0,7 & - & 0,7 & - & 0,7 \\
\hline 6 & - & - & - & - & - & - & - & - & - \\
\hline 7 & 0,3 & - & 0,7 & - & 0,5 & - & 0,45 & - & 0,7 \\
\hline 8 & - & - & - & - & - & - & - & - & - \\
\hline 9 & 0,5 & - & 0,7 & - & 0,55 & - & 0,6 & - & 0,5 \\
\hline \multicolumn{10}{|l|}{ EM-34 V } \\
\hline 1 & 1,0 & - & 0,5 & - & 1,2 & - & 0,9 & - & 1,1 \\
\hline 2 & - & - & - & - & - & - & - & - & - \\
\hline 3 & 1,4 & - & 1,2 & - & 0,8 & - & 0,6 & - & 0,9 \\
\hline 4 & - & - & - & - & - & - & - & - & - \\
\hline 5 & 0,5 & - & 0,5 & - & 0,85 & - & 1,0 & - & 0,8 \\
\hline 6 & - & - & - & - & - & - & - & - & - \\
\hline 7 & 1,1 & - & 0,7 & - & 1,1 & - & 0,5 & - & 0,4 \\
\hline 8 & - & - & - & - & - & - & - & - & \\
\hline 9 & 0,6 & - & 0,65 & - & 0,7 & - & 0,8 & - & 0,5 \\
\hline
\end{tabular}


Os valores de condutividade aparente obtidos com o EM-31 e o EM-34 foram muito baixos, conforme apresentado na tabela 4.4, sendo um pouco maiores para as profundidades de $2,81 \mathrm{e}$ 5,62, mais próximas da superfície do solo. Estes valores indicam que a área não apresenta alterações na qualidade das águas das zonas não saturada e saturada causadas por substâncias inorgânicas, mesmo tendo sido submetida a uma aplicação de vinhaça antes da seleção da área.

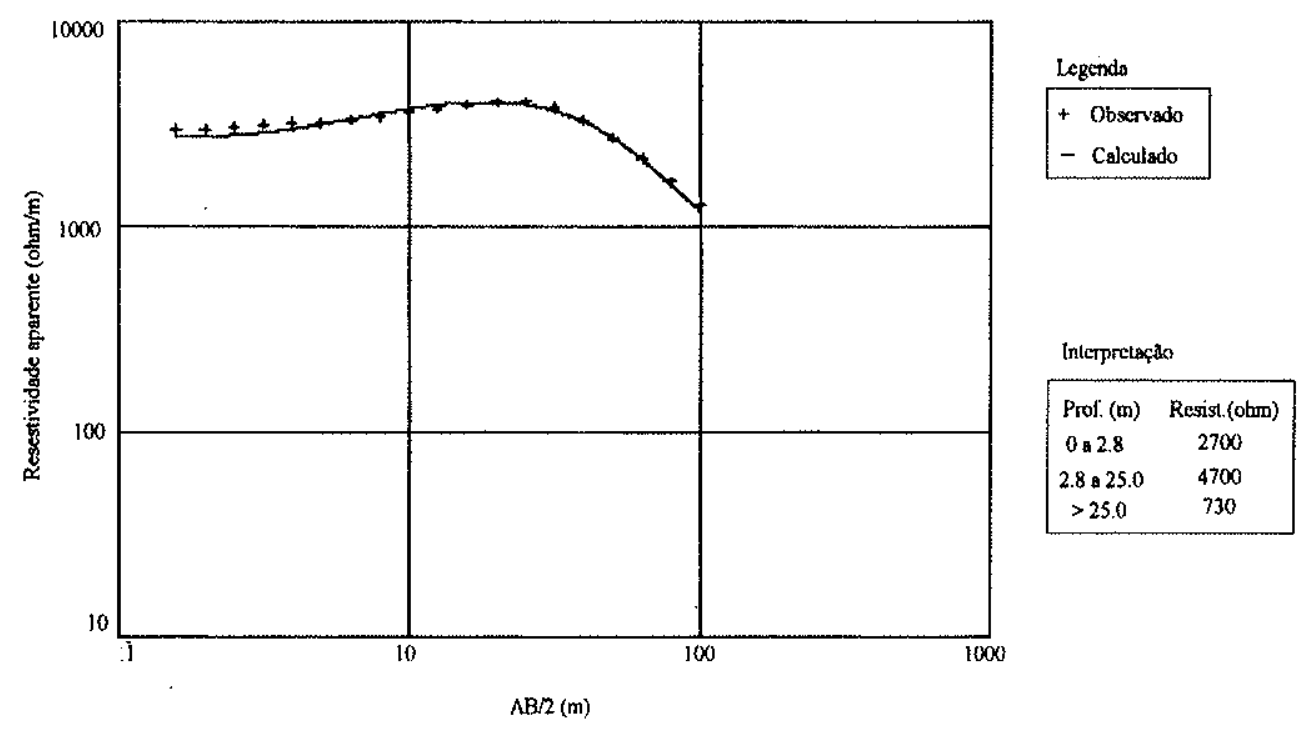

Figura 4.6 - Sondagem elétrica 1

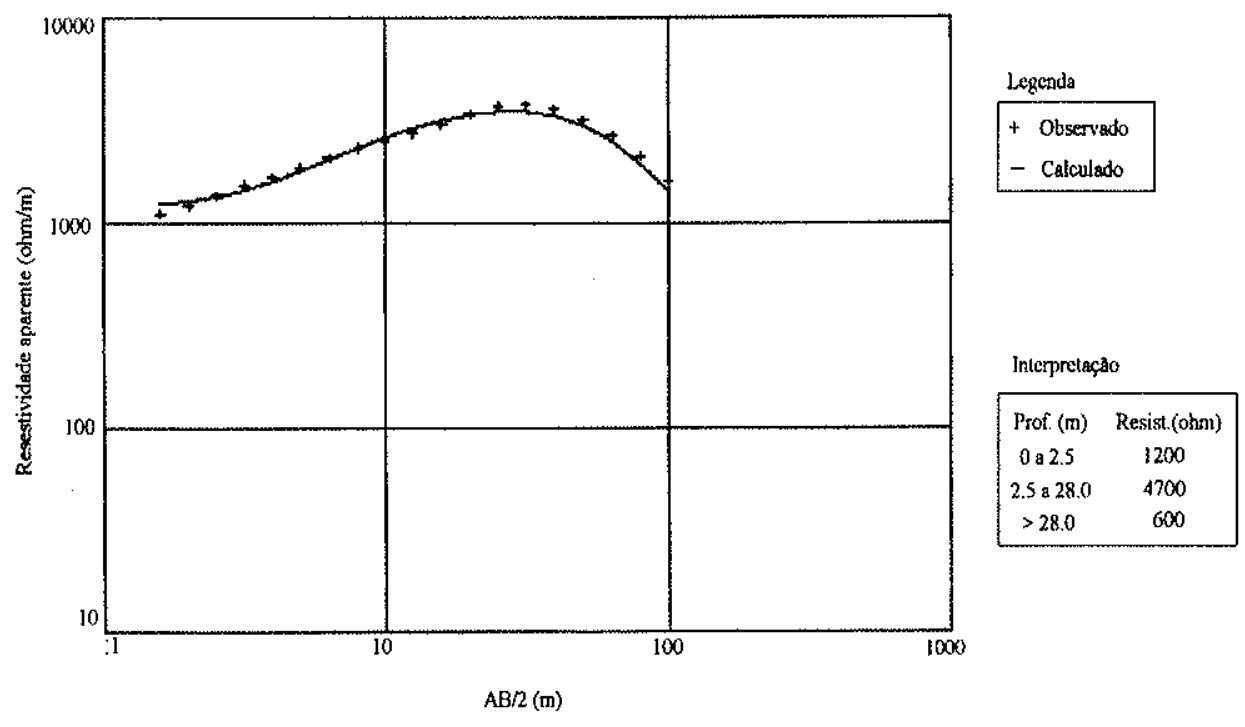

Figura 4.7 - Sondagem elétrica 2

As sondagens elétricas apresentadas nas figuras 4.6 e 4.7 definiram 3 camadas: a primeira, com resistividade intermediária, que corresponde a zona não saturada, constituída por solo e/ou 
sedimentos derivados da Formação Botucatu; a segunda, de resistividade maior, corresponde a sedimentos da Formação Botucatu saturados; a terceira corresponde, provavelmente, a sedimentos saturados da Formação Pirambóia, mais argilosa, com resistividade menor. Esta interpretação encontra apoio nas descrições realizadas a partir das sondagens, nas medidas de nível de água nos poços de monitoramento, nas medidas de condutividade elétrica da água coletada nos poços instalados e nos dados estratigráficos da região. Pode-se concluir, também, que não existem corpos intrusivos de diabásio na área, ocorrendo no local um pacote de sedimentos da Formação Botucatu com aproximadamente $28 \mathrm{~m}$ de espessura.

\section{3- Instalação dos equipamentos de monitoramento}

O posicionamento dos equipamentos de monitoramento foi definido em função do sentido de fluxo das águas subterrâneas determinado durante a fase de caracterização hidrogeológica da área (figura 4.4).

\subsection{1- Instalação dos equipamentos de monitoramento da zona não saturada}

Foram instalados 9 conjuntos, compostos por 6 tensiômetros, instalados nas profundidades de 20 , $60,100,140,180$ e $220 \mathrm{~cm}$ em perfurações realizadas com trados manuais para execução das perfurações. O esquema de construção e instalação dos tensiômetros é mostrado na figura 4.8.

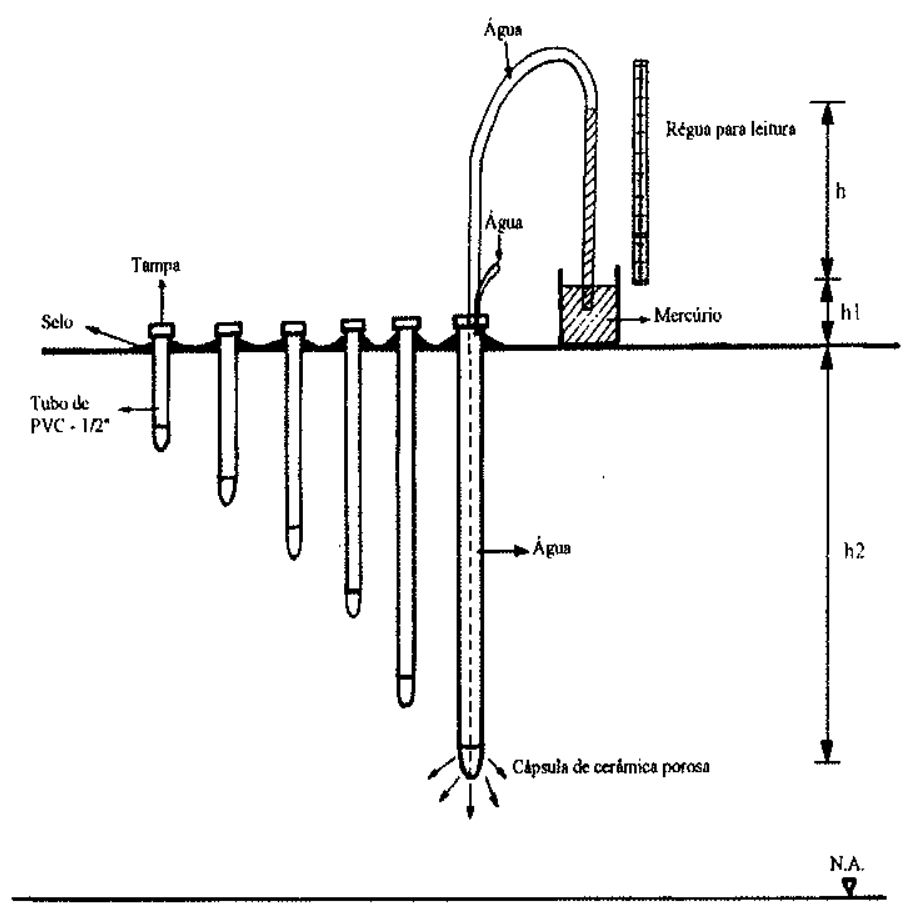

Figura 4.8 - Esquema de construção e instalação dos tensiômetros 
Os tensiômetros foram construídos com tubos de P.V.C. de 1/2" de diâmetro, para a confecção da câmara de armazenamento da água, tubos de nylon com diâmetro de 3/8", utilizados para construir o manômetro de mercúrio e condutos de água, cápsulas porosas de cerâmica com 1/2" de diâmetro e $6 \mathrm{~cm}$ de comprimento, e estrutura de madeira para fixar o manômetro.

Os tensiômetros foram instalados em perfurações estreitas, com diâmetro um pouco maior do que o diâmetro da cápsula porosa (1/2"). Para assegurar um bom contato hidráulico entre as paredes da perfuração e a cápsula porosa foi adicionado entre elas uma massa confeccionada com o material retirado da perfuração e água destilada.

As leituras dos tensiômetros foram feitas 2 ou 3 vezes por semana, através de seus manômetros de mercúrio. Foi utilizada água destilada fervida nos tensiômetros para evitar o aparecimento de bolhas de ar, embora frequentemente fosse necessária a eliminação de bolhas de ar nas tubulações através da introdução de água fervida.

O cálculo do potencial matricial a partir das medidas obtidas nos tensiômetros foi realizado através da equação:

$\psi_{\mathrm{m}}=-12.6 \mathrm{~h}+\mathrm{h}_{1}+\mathrm{h}_{2}$

conforme esquema da figura 4.8 (REICHARDT, 1985).

O cálculo do potencial hidráulico, $\psi$, na zona não saturada, em locais e profundidades diferentes, dentro da zona não saturada da área de estudo pode ser calculado por:

$\psi=\psi_{\mathrm{m}}+\psi_{\mathrm{g}}$

onde $\psi_{\mathrm{g}}$ é o potencial gravitacional, sendo neste caso igual a $\mathrm{h}_{2}$, considerando-se o plano referencial a superfície do terreno, conforme esquema da figura 4.8 .

Próximos aos tensiômetros foram instalados 9 conjuntos com 5 lisímetros de sucção cada, instalados nas profundidades de $40,80,120,160$ e $200 \mathrm{~cm}$ utilizando-se trados manuais para execução das perfurações. A figura 4.9 apresenta o esquema de construção e instalação dos lisímetros utilizados no estudo. 


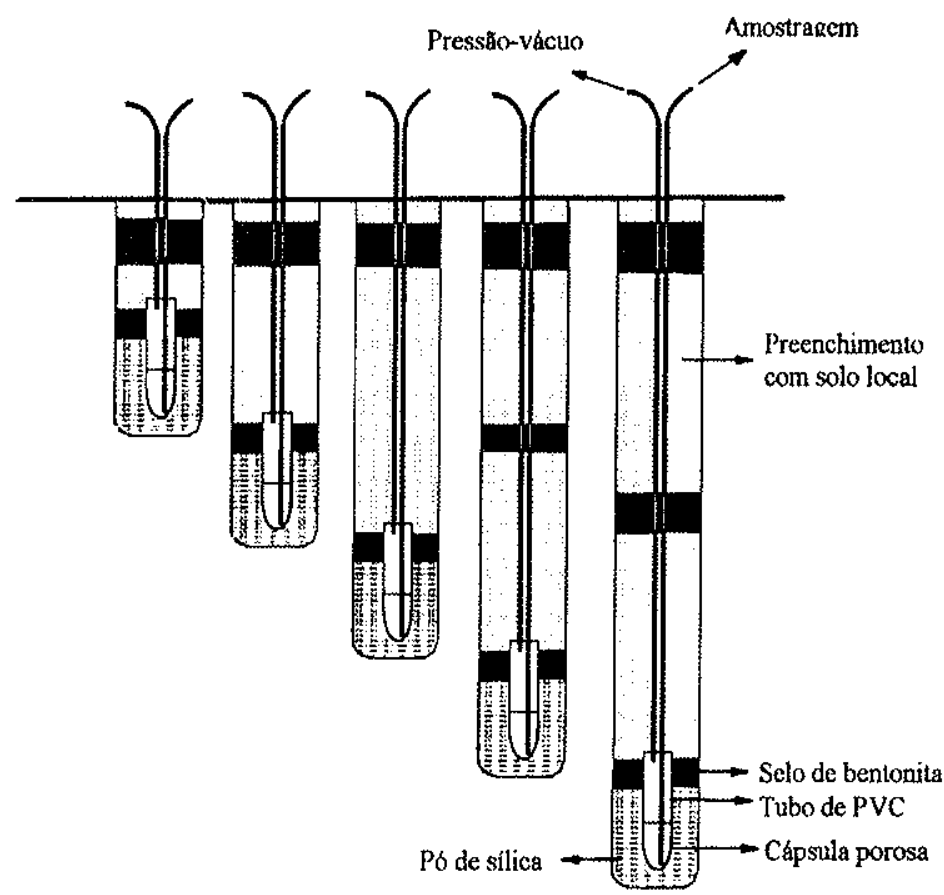

Figura 4.9 - Esquema de construção e instalação dos lisímetros de sucção

Os lisímetros foram construídos com tubos de P.V.C. de 2" de diâmetro e $17 \mathrm{~cm}$ de comprimento,

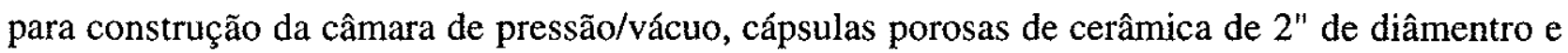
$7 \mathrm{~cm}$ de comprimento. tubos de nylon com diâmetro de $3 / 8^{\prime \prime}$, que foram utilizados para confeccionar os dutos para coleta de amostra e aplicação de vácuo/pressão.

As cápsulas porosas de cerâmica utilizadas para confeccionar estes lisímetros de sucção foram lavadas com ácido clorídrico 1 normal e posteriormente com água deionizada, até que a condutividade elétrica da água que saia da cápsula fosse igual à da água deionizada que entrava nesta para lavagem. As cápsulas porosas dos lisímetros e dos tensiômetros foram selecionadas após a realização de testes de velocidade de drenagem de água deionizada por gravidade pelas cápsulas. Foram selecionadas as cápsulas com velocidade de drenagem semelhantes para evitar diferentes taxas de vácuo nos lisímetros e diferentes tempos de resposta nos tensiômetros. Além disso, após a construção dos tensiômetros e lisímetros, estes foram submetidos a testes de pressão a fim de verificar a existência de vazamentos.

Para cada subdivisão da área de estudo (áreas 1,2 e 3), as medidas de potencial matricial e as amostras de água para análises químicas foram tomadas com 3 repetições para cada profundidade, sendo calculados seus valores médios. 
Foram instalados nas trincheiras utilizadas para coleta de amostras indeformadas (figura 4.2) 3 panlisímetros (amostradores de drenagem livre) na profundidade de $50 \mathrm{~cm}$ e 3 na profundidade de $150 \mathrm{~cm}$, conforme o esquema da figura 3.8 .

\subsection{2- Instalação dos equipamentos de monitoramento da zona saturada}

$\mathrm{Na}$ área de estudo foram instalados 3 poços de monitoramento tipo multinível com filtro curto $(50 \mathrm{~cm})$ locados em duas profundidades, a partir de perfurações a trado manual, conforme esquema da figura 4.10. As características destes poços são apresentadas na tabela 4.5.

Estes poços foram construídos com tubos de P.V.C. de 1" de diâmetro, sendo o poço mais profundo do multinível instalado em uma perfuração com $2^{\prime \prime}$ de diâmetro e preenchido o espaço anular entre o tubo e a parede da perfuração com areia composta de quartzo. Os filtros dos poços possuiam $50 \mathrm{~cm}$ de comprimento, sendo envoltos por uma tela de nylon. $O$ isolamento dos filtros colocados em diferentes profundidades foi obtido através de um selo de bentonita. Na parte superior do multinínel a perfuração possue diâmentro de 4".

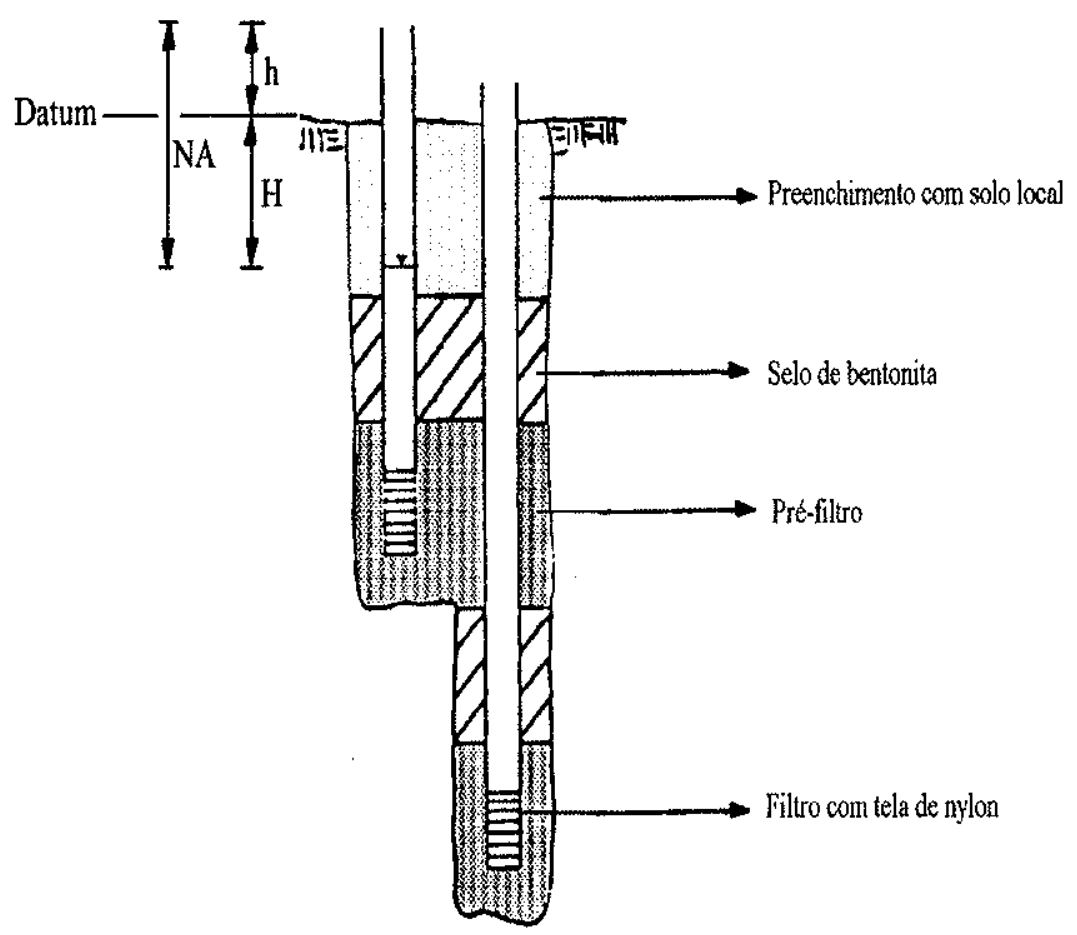

Figura 4.10 - Esquema de construção e instalação dos poços de monitoramento multiníveis 
Tabela 4.5 - Características dos multiníveis

\begin{tabular}{|c|c|c|c|}
\hline Equipamento & $\begin{array}{c}\text { Cota } \\
(\mathrm{cm})\end{array}$ & $\begin{array}{c}\text { Profundidade } \\
\text { instalação } \\
(\mathrm{cm})\end{array}$ \\
\hline MN1 - S & 0,0 & 33,00 & 297,00 \\
\hline MN1 - P & 0,0 & 50,00 & 450,00 \\
\hline MN2 - S & 0,0 & 44,00 & 308,00 \\
\hline MN2 - P & 0,0 & 55,00 & 448,00 \\
\hline MN3 - S & 0,0 & 64,00 & 288,00 \\
\hline MN3 - P & 0,0 & 53,00 & 447,00 \\
\hline
\end{tabular}

Estes multiníveis foram utilizados para coleta de amostras de água da zona saturada para realização de análises químicas e para coleta de dados puntuais de potencial hidráulico em profundidade, com o intuito de verificar a existência de fluxo vertical na área. O potencial hidráulico foi calculado, a partir de medidas de nível d'água tomadas nestes poços, utilizando-se a equação 4.6 , conforme o esquema da figura 4.10 .

$\mathrm{H}=\mathrm{NA}-\mathrm{h}$

onde $\mathrm{H}$ é o potencial hidráulico, NA é o valor da medida de nível d'água dentro do poço e h é a altura do tubo acima da superfície. O plano referencial utilizado foi a superfície do terreno, sendo sua cota topográfica considerada como $0,0 \mathrm{~cm}$.

Para determinação da condutividade hidráulica saturada foram realizados "slug tests" nos poços de monitoramento multiníveis, cuja descrição é apresentada no ítem 5.1.

\section{4- Aplicação da vinhaça na área de estudo}

$\mathrm{Na}$ área de estudo foram aplicadas taxas diferentes de vinhaça nas áreas A1 e A3, conforme o esquema da figura 4.2. Na área $\mathrm{A}_{2}$ não foi aplicada vinhaça, pois pensava-se em utilizar esta área para coleta de amostras de água da zona não saturada que representassem as suas características naturais ("background").

A área $A_{1}$ recebeu a taxa de $150 \mathrm{~m}^{3} / \mathrm{ha}$, taxa normalmente utilizada para fertirrigação com caminhões tanque e na área $A_{3}$ foi aplicada a taxa de $300 \mathrm{~m}^{3} /$ ha, que corresponde a taxa normalmente utilizada na fertirrigação com canhão de aspersão.

Para a aplicação da vinhaça foi utilizado um caminhão tanque, do qual a vinhaça era distribuída por gravidade para o terreno, através de uma mangueira. No fim da mangueira foi adaptado um bocal de um regador, proporcionando o espalhamento da vinhaça. A vazão de saída era 
constantemente medida para que a aplicação de vinhaça fosse homogênea em toda a área de aplicação.

A vinhaça aplicada foi coletada e submetida a análises químicas, cujos resultados são apresentados na tabela 4.6 .

Tabela 4.6 - Análises químicas da vinhaça aplicada (concentrações em mg/l)

\begin{tabular}{|l|l|l|l|l|l|l|l|l|l|}
\hline $\mathrm{Ca}$ & $\mathrm{Cl}$ & $\mathrm{Mg}$ & $\mathrm{N}-\mathrm{NH} 4$ & $\mathrm{~N}-\mathrm{NO} 3$ & $\mathrm{~N}-\mathrm{NO} 2$ & $\mathrm{NKT}$ & $\mathrm{K}$ & $\mathrm{SO} 4$ & TOC \\
\hline 105 & 673 & 84 & 11 & 0,06 & 0,01 & 140 & 1200 & 879 & 21.300 \\
\hline 110 & 673 & 82 & 13 & 0,1 & 0,01 & 130 & 1200 & 879 & 22.600 \\
\hline
\end{tabular}

\section{5- Monitoramento das zonas não saturada e saturada}

Os parâmetros selecionados para determinação da qualidade natural das águas das zonas não saturada e saturada foram: cloreto, sulfato, nitrogênio nitrato, nitrogênio nitrito, nitrogênio amoniacal, nitrogênio Kjeldahl total, alcalinidade bicarbonato e carbonato, cálcio, magnésio, sódio, potássio, ferro, condutividade elétrica, $\mathrm{pH}$ e carbono orgânico dissolvido. Em função da composição química da vinhaça e de sua importância relativa à poluição das águas subterrâneas foram escolhidos os seguintes parâmetros prioritários para análise, caso ocorresse problemas na amostragem: carbono orgânico dissolvido, cloreto, nitrogênio nitrato, nitrogênio amoniacal, nitrogênio Kjeldahl, sulfato e potássio.

Foram realizadas 5 amostragens de água de todos os equipamentos de monitoramento, sendo uma antes da aplicação de vinhaça na área e 4 após a aplicação.

Para amostragem de água dos lisímetros de sucção, inicialmente era aplicado vácuo em suas câmaras, sendo este vácuo mantido por aproximadamente 24 horas para que a água da zona não saturada penetrasse nos lisímetros. Após isto a água era retirada do lisímetro aplicando-se pressão na câmara, proporcionando a coleta da água, que era então preservada para análise.

As águas dos poços de monitoramento e panlisímetros foram amostradas utilizando-se também uma bomba de vácuo. 


\section{5- APRESENTAÇÃO E INTERPRETAÇÃO DOS RESULTADOS}

\section{1- Fluxo de água na zona saturada}

As medidas de potencial hidráulico realizadas em diferentes datas demonstram que o fluxo das águas subterrâneas na área de estudo é praticamente horizontal, pois foram detectados apenas pequenas diferenças de potencial hidráulico $(\mathrm{H})$ nos poços de monitoramento tipo multinível em algumas datas, conforme é apresentado na figura 5.1 e na tabela 5.1.
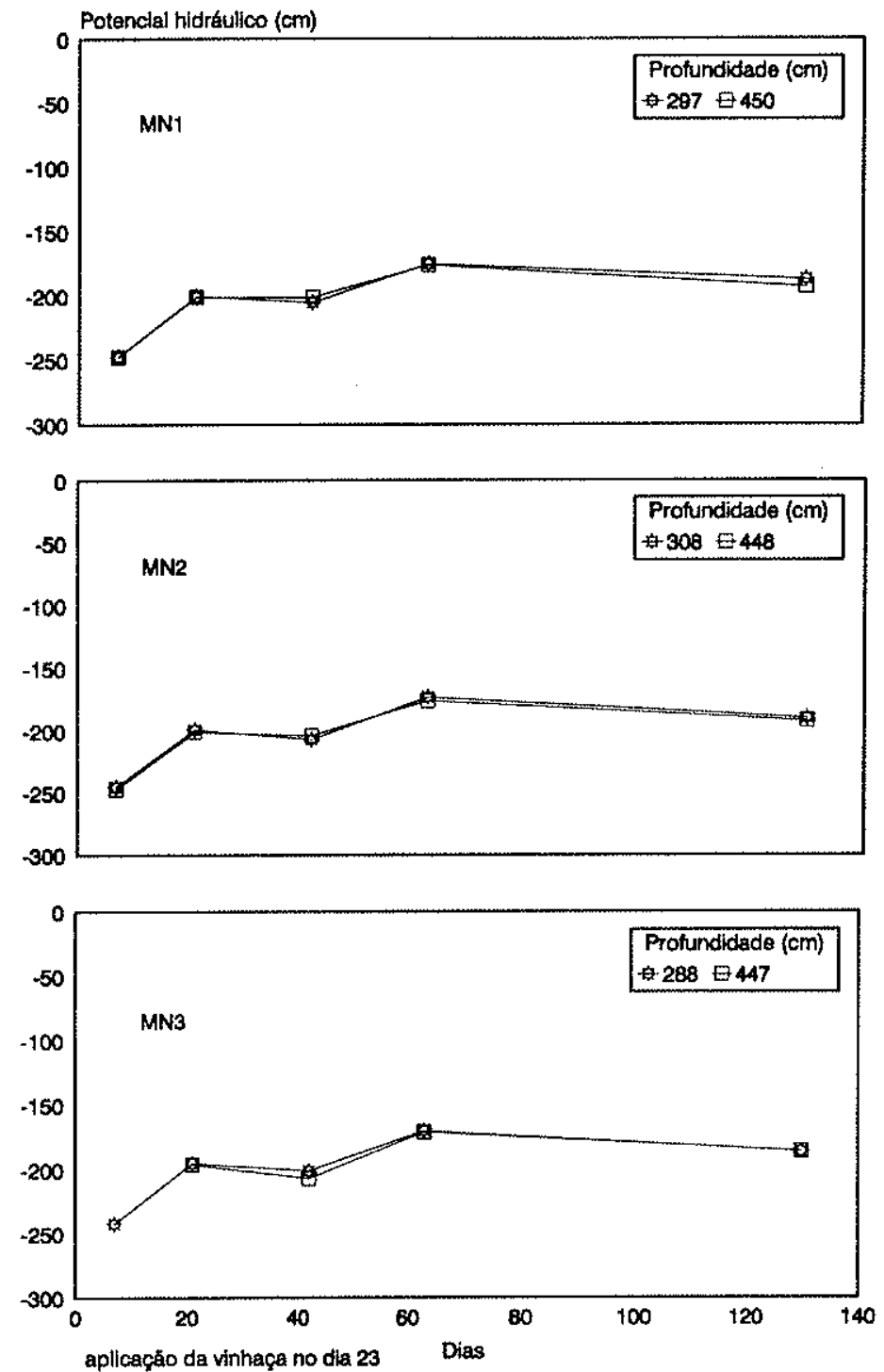

Figura 5.1 - Potencial hidráulico nos multiníveis 
Tabela 5.1 - Potencial hidráulico nos multiníveis

\begin{tabular}{|c|c|c|c|c|c|c|c|}
\hline Data & & MN1 - S & MN1 - P & MN2 - S & MN2 - P & MN3 - S & MN3 - P \\
\hline $07 / 11 / 89$ & Nível (cm) & 280,50 & 298,00 & 289,00 & 302,00 & 306,00 & 283,00 \\
\cline { 2 - 8 } & H(cm) & 247,50 & 248,00 & 245,00 & 247,00 & 242,00 & \\
\hline \multirow{2}{*}{$21 / 11 / 89$} & Nível (cm) & 233,50 & 251,00 & 243,00 & 256,00 & 259,00 & 249,00 \\
\cline { 2 - 8 } & $\mathrm{H}(\mathrm{cm})$ & 200,50 & 201,00 & 199,00 & 201,00 & 195,00 & 196,00 \\
\hline \multirow{2}{*}{$12 / 12 / 89$} & Nível (cm) & 238,00 & 251,00 & 251,00 & 259,00 & 265,00 & 260,00 \\
\cline { 2 - 8 } & $\mathrm{H}(\mathrm{cm})$ & 205,00 & 201,00 & 207,00 & 204,00 & 201,00 & 207,00 \\
\hline \multirow{2}{*}{$02 / 01 / 90$} & Nível (cm) & 208,00 & 226,00 & 217,00 & 231,00 & 234,00 & 224,00 \\
\cline { 2 - 8 } & $\mathrm{H}(\mathrm{cm})$ & 175,00 & 176,00 & 173,00 & 176,00 & 170,00 & 171,00 \\
\hline \multirow{2}{*}{$10 / 04 / 90$} & Nível (cm) & 220,00 & 243,00 & 234,00 & 247,00 & 250,00 & 239,00 \\
\cline { 2 - 8 } & $\mathrm{H}(\mathrm{cm})$ & 187,00 & 193,00 & 190,00 & 192,00 & 186,00 & 186,00 \\
\hline
\end{tabular}

Os valores de condutividade hidráulica foram obtidos através da execução de "slug tests" realizados no poço de monitoramento tipo multinível 2 (MN2 - profundidade de $448 \mathrm{~cm}$ ).

O "slug test", desenvolvido por HVORSLEV (1951, in FREEZE \& CHERRY, 1979), consiste da introdução ou retirada de um cilindro com volume conhecido dentro de um poço, o que causa a elevação ou rebaixamento do nível d'água dentro deste. Através de um medidor de nível d'água são observados o nível d'água antes da introdução ou retirada do cilindro, o nível d'água imediatamente após a introdução ou retirada do cilindro e as as variações do nível d'água até que este volte a seu nível original.

Este teste foi realizado utilizando-se a expressão:

$K=\frac{r_{c}^{2} \ln \left(\frac{L}{r_{S}}\right)}{2 L T_{0}}$

que foi definida para ser utilizada em um poço onde a relação $L / r_{S}>8$. Na equação $5.1 r_{C}$ $(1,27 \mathrm{~cm})$ é o raio da tubulação do poço, $L(50 \mathrm{~cm})$ é o comprimento do pré-filtro do poço, $\mathrm{r}_{\mathrm{S}}$ $(2,54 \mathrm{~cm})$ é o raio da perfuração e $\mathrm{T}_{0}$ é obtido graficamente, conforme apresentado na figura 5.2. A partir do valor 0,37 no eixo das ordenadas, o valor de $T_{0}$ corresponde ao tempo obtido no eixo das abcissas, tendo por base a reta calculada obtida. Esta figura mostra os dados obtidos no teste, onde $\mathrm{H}$ é o nível d'água no poço antes da introdução ou retirada do cilindro, $\mathrm{H}_{0}$ é o nível d'água inicial imediatamente após a introdução ou retirada do cilindro e h são as várias medidas de nível d'água realizadas para acompanhar a subida ou descida do nível d'água no poço. 

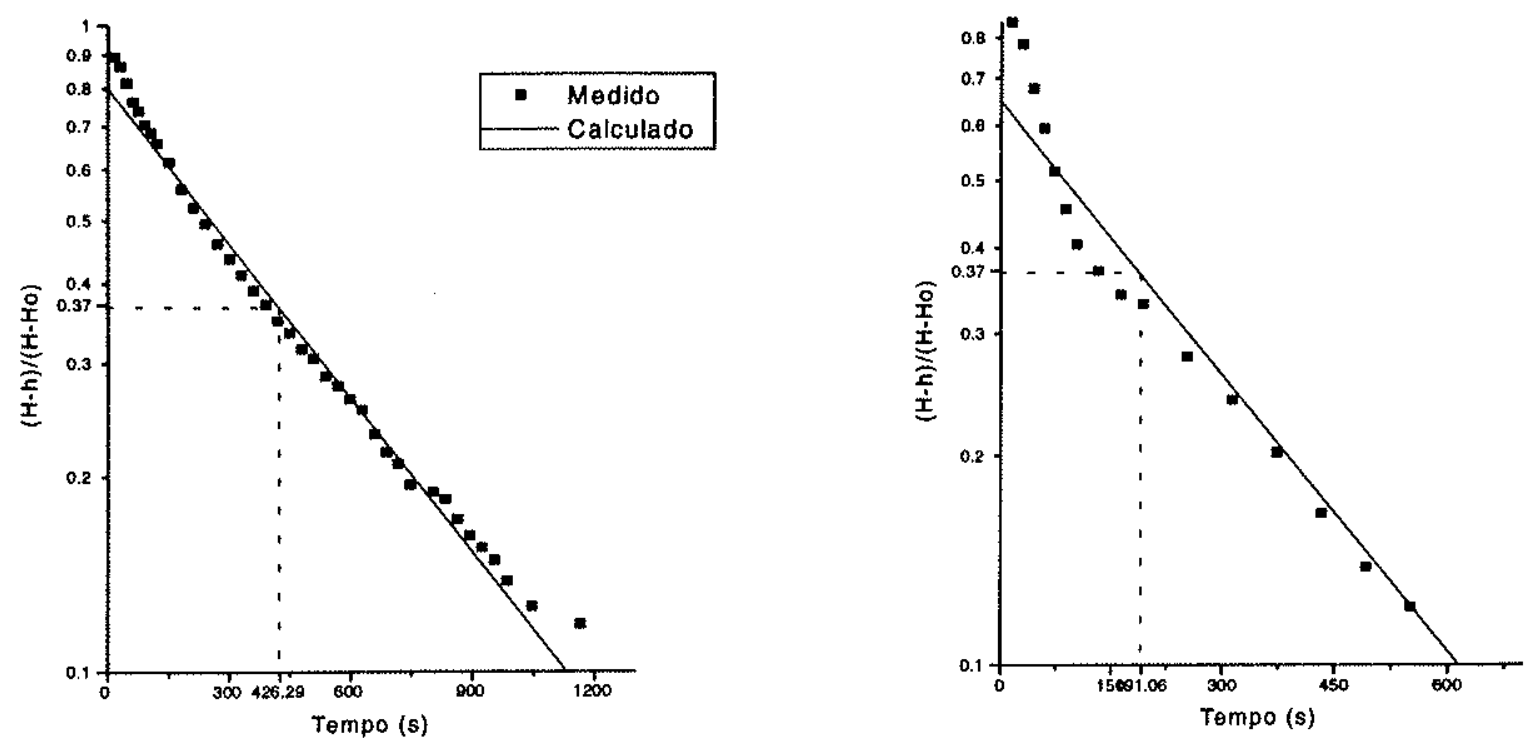

Figura 5.2 - "Slug test"

Os valores de condutividade hidráulica obtidos nestes testes foram: $1,127 \times 10^{-4} \mathrm{~cm} / \mathrm{s}$ (durante a subida do nível d'água do poço) e $2,515 \times 10^{-4} \mathrm{~cm} / \mathrm{s}$ (durante a descida do nível d'água).

A porosidade efetiva foi estimada utilizando-se a curva de retenção de água para a profundidade de $220 \mathrm{~cm}$. Conforme a tabela 5.2 , subtraindo-se $\theta_{\mathrm{r}}(3,28 \%)$ de $\theta_{\mathrm{S}}(40,76 \%)$, obtém-se a vazão específica ou porosidade efetiva. O valor obtido nesta estimativa é de $37,48 \%$. Em material arenoso a porosidade efetiva possui valor próximo ao da porosidade total.

Desta forma, pode-se calcular a velocidade das águas subterrâneas na área de estudo utilizandose a Lei de Darcy. Considerando-se o gradiente de potencial hidráulico obtido na figura 4.4a como sendo 0,025 , a condutividade hidráulica como sendo $2,515 \times 10^{-4} \mathrm{~cm} / \mathrm{s}$, a velocidade das águas subterrâneas pode ser estimada em $1,67 \times 10^{-5} \mathrm{~cm} / \mathrm{s}$ ou $1,44 \mathrm{~cm} / \mathrm{dia}$.

\section{2- Fluxo de água na zona não saturada}

Devido a necessidade de trabalhos de manutenção constante nos tensiômetros, foram obtidas leituras significativas do potencial matricial em apenas dois períodos: o primeiro de 03/05/89 a 29/07/89 e o segundo de 01/11/89 a 12/12/89. 
A partir dos valores de potencial matricial calculados, através da equação 4.4, e apresentados nas tabelas 1 e 2 do anexo 1, pode-se utilizar as equações de van Genuchten para calcular o conteúdo volumétrico de água, $\theta$, e os valores de condutividade hidráulica não saturada, $K(\theta)$, para todas as profundidades e datas de medição.

Para tornar possível estes cálculos devem ser obtidos os parâmetros de van Genuchten (m, n, e $\alpha$ ). Para tanto foram utilizadas as curvas de retenção de água, apresentadas na figura 4.5, e o programa RETC.F77 (U.S. SALINITY LABORATORY, 1987), que utiliza as equações de van Genuchten e as curvas de retenção de água para executar estes cálculos.

A partir destas curvas, obtidas experimentalmente, este programa, através de métodos numéricos, calcula os parâmetros de van Genuchten referentes a uma curva de retenção teórica, que se aproxima da curva experimental.

Na tabela 5.2 são apresentados os parâmetros de van Genuchten calculados pelo programa e no anexo 2, pode-se observar as saídas obtidas do programa RETC.F77.

Tabela 5.2 - Parâmetros de van Genuchten calculados pelo RETC

\begin{tabular}{|c|c|c|c|c|c|c|c|}
\hline $\begin{array}{c}\text { Profundidade } \\
(\mathrm{cm})\end{array}$ & $\begin{array}{c}\text { Teta r } \\
\left(\mathrm{cm}^{3 /} / \mathrm{cm}^{3}\right)\end{array}$ & $\begin{array}{c}\text { Teta sat } \\
\left(\mathrm{cm}^{3} / \mathrm{cm}^{3}\right)\end{array}$ & $\alpha$ & $\mathrm{n}$ & $\mathrm{m}$ & $\begin{array}{c}\text { Ksat } \\
(\mathrm{cm} / \mathrm{s})\end{array}$ & $\begin{array}{c}\text { Ksat } \\
(\mathrm{cm} / \text { dia })\end{array}$ \\
\hline 20 & 0,0266 & 0,4046 & 0,03123 & 2,3832 & 0,580396 & $2,52 \mathrm{E}-04$ & $2,17 \mathrm{E}+01$ \\
\hline 60 & 0,0264 & 0,3709 & 0,02895 & 2,57033 & 0,610945 & $2,52 \mathrm{E}-04$ & $2,17 \mathrm{E}+01$ \\
\hline 100 & 0,0318 & 0,3728 & 0,03311 & 2,53363 & 0,605309 & $2,52 \mathrm{E}-04$ & $2,17 \mathrm{E}+01$ \\
\hline 140 & 0,0349 & 0,3926 & 0,03056 & 2,3017 & 0,565539 & $2,52 \mathrm{E}-04$ & $2,17 \mathrm{E}+01$ \\
\hline 180 & 0,033 & 0,3828 & 0,0229 & 2,08216 & 0,51973 & $2,52 \mathrm{E}-04$ & $2,17 \mathrm{E}+01$ \\
\hline 220 & 0,0328 & 0,4076 & 0,03457 & 2,1572 & 0,536436 & $2,52 \mathrm{E}-04$ & $2,17 \mathrm{E}+01$ \\
\hline
\end{tabular}

$\mathrm{Na}$ tabela 5.2 são apresentados os valores de teta $\mathrm{r}\left(\theta_{\mathrm{r}}\right)$, que é o valor do conteúdo de água residual correspondente ao potencial de pressão de $15.000 \mathrm{~cm}$ de água e teta sat $\left(\theta_{\text {sat }}\right)$, que é o conteúdo de água na saturação. Estes valores foram obtidos diretamente nas curvas de retenção de água, enquanto que o valor de $\mathrm{K}_{\text {Sat }}$ (condutividade hidráulica na saturação) foi obtido do "slug test" realizado.

Calculados os parâmetros de van Genuchten, pode-se calcular os valores de $\theta$ e $K(\theta)$ através das equações 3.14 e 3.22, cujos resultados são apresentados nas tabelas 1 e 2 do anexo 1 .

Obtidos estes dados, utilizando-se a Lei de Darcy, pode-se calcular o fluxo ou velocidade de Darcy, $q$, e a velocidade de fluxo da água, v, para diversas camadas da zona não saturada, através das expressões: 
$q=K(\theta) \frac{\Delta \psi}{\Delta z}$

e

$\mathrm{v}=\frac{\mathrm{q}}{\theta}$

Utilizando-se também as medidas de potencial matricial pode-se calcular os valores de potencial hidráulico correspondentes, utilizando-se a equação 4.5 .

Os resultados dos cálculos realizados para determinar o potencial matricial, o potencial hidráulico, o conteúdo volumétrico de água, a condutividade hidráulica não saturada, o fluxo ou velocidade de Darcy e a velocidade de fluxo de água para estes dois períodos são apresentados nas tabela 1 e 2 do anexo 1.

A figura 5.3 mostra a variação do potencial hidráulico com o tempo no primeiro período de medidas, para as profundidades de $20,60,100,140,180$ e $220 \mathrm{~cm}$, nas áreas 1,2 e 3, e a figura 5.4 apresenta estas mesmas determinações para o segundo período de medidas.

O sentido de fluxo das águas nas zonas não saturada e saturada pode ser definido observando-se as diferenças de valores de potencial hidráulico entre as diferentes profundidades. $O$ fluxo de água ocorre do ponto onde os valores de potencial hidráulico são maiores para o ponto onde são menores. No caso das figuras 5.3 e 5.4 os valores altos de potencial hidráulico são aqueles que possuem sinais negativos cujos valores em módulo são baixos, e os valores baixos de potencial hidráulico são aqueles que possuem sinais negativos cujos valores em módulo são altos.

Na figura 5.3 são apresentadas as variações do potencial hidráulico nas profundidades de 20,60, $100,140,180$ e $220 \mathrm{~cm}$ em um perído caracterizado por baixa pluviosidade. O dia 03/05/89 equivale ao dia 1 nas figuras 5.3.

Os valores de potencial hidráulico obtidos nas áreas 1,2 e 3 para todas as profundidades apresentaram valores próximos, principalmente para as profundidades de $100,140,180$ e $220 \mathrm{~cm}$, ocorrendo desta forma baixos gradientes de potencial hidráulico entre estas profundidades. 


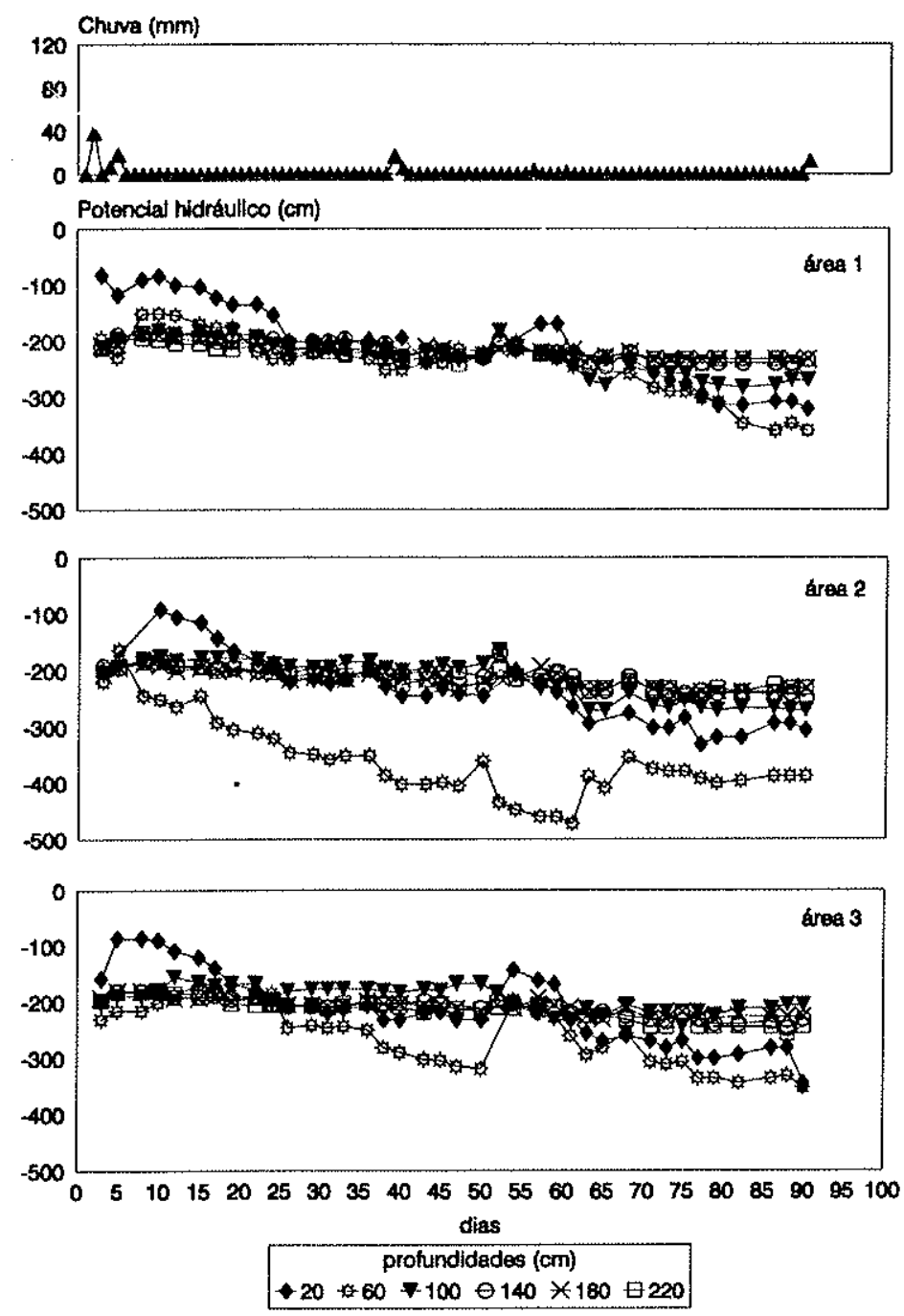

Figura 5.3 - Potencial hidráulico na zona não saturada (3/5/89 a 29/7/89)

Verifica-se nesta figura a existência de alternâncias constantes no sentido de fluxos de água podendo ser ascendentes, quando o potencial hidráulico em uma profundidade mais distante da superfície do terreno é maior do que o potencial hidráulico em uma profundidade mais próxima da superfície do terreno, ou descendentes, caso contrário. Na tabela 1 , do anexo 2, também podese observar este fato. Se o sinal dos valores de fluxo (q) for positivo o fluxo de água é descendente e se for negativo ascendente.

Nos primeiros 20 dias, por exemplo, observando-se os dados da área 1, nota-se o predomínio de fluxo descendente e nos últimos dias do período, entre os dias 75 e 90 aproximadamente, nota-se o predomínio de fluxo ascendente.

A profundidade de $20 \mathrm{~cm}$ apresenta um comportamento nas variações de potencial hidráulico, em relação ao comportamento observado nas outras profundidades, um pouco diferente nos primeiros dias do período (do dia 1 ao dia 20 aproximadamente) devido à influência das chuvas 
ocorridas no início deste período. Estas chuvas causaram um aumento do conteúdo de água nesta profundidade, principalmente, elevando-se desta forma os valores de potencial hidráulico. A curva de $60 \mathrm{~cm}$, na área 1, acompanha esta mesma tendência. Após este intervalo de tempo, os valores de potencial hidráulico a $20 \mathrm{~cm}$ acompanham a mesma tendência das outras profundidades, que é a diminuição dos valores com o tempo.

Os valores de potencial hidráulico na profundidade de $60 \mathrm{~cm}$ nas áreas 1,2 e 3 apresentam valores bastante diferentes, comparando-os entre si. Provavelmente este fato ocorreu devido ao mau funcionamento dos tensiômetros das áreas 2 e 3, que embora apresentem a tendência de diminuição dos valores de potencial hidráulico com o tempo, seus valores diferem dos valores obtidos na área 1. Estes provavelmente são corretos, pois acompanham a mesma tendência dos valores observados nas outras profundidades, principalmente as variações observadas na profundidade de $20 \mathrm{~cm}$.

As profundidades de 180 e $220 \mathrm{~cm}$ apresentam as menores variações de potencial hidráulico devido à influência das águas da zona saturada. A posição do nível d'água freático nesta época provavelmente encontrava-se próxima aos tensiômetros de $220 \mathrm{~cm}$. Devido à baixa pluviosidade e baixa recarga das águas subterrâneas locais provavelmente ocorreu nesta época uma descida gradual do nível d'água, fato constatado pela pequena variação dos valores de potencial hidráulico para estas profundidades.

Na figura 5.4 são apresentadas as variações do potencial hidráulico nas profundidades de 20,60 , $100,140,180$ e $220 \mathrm{~cm}$, nas áreas 1,2 e 3, em um perído caracterizado por alta pluviosidade. $\mathrm{O}$ dia $01 / 11 / 89$ equivale ao dia 1 na figura 5.4 .

Os valores de potencial hidráulico obtidos nas áreas 1, 2 e 3 são bastante parecidos, indicando bom funcionamento dos tensiômetros e homogeneidade das características hidrogeológicas da área de estudo.

Podemos notar nesta figura que após o dia 10, ocorre um período de chuvas constantes. Neste intervalo as diferenças dos valores de potencial hidráulico entre as diferentes profundidades são grandes, se comparados às diferenças ocorridas no período seco. Nota-se também a predominância de fluxo de água descendente entre as diferentes profundidades.

No intervalo inicial de tempo, entre os dias 1 e 10 ocorre um pequeno período sem chuvas, onde ocorre o decréscimo do potencial hidráulico em todas as profundidades e a ocorrência de fluxos de água ascendentes, conforme pode ser observado também na tabela 2 do anexo 1 , onde ocorrem valores negativos de fluxo (q), principalmente na camada $100-140 \mathrm{~cm}$. 

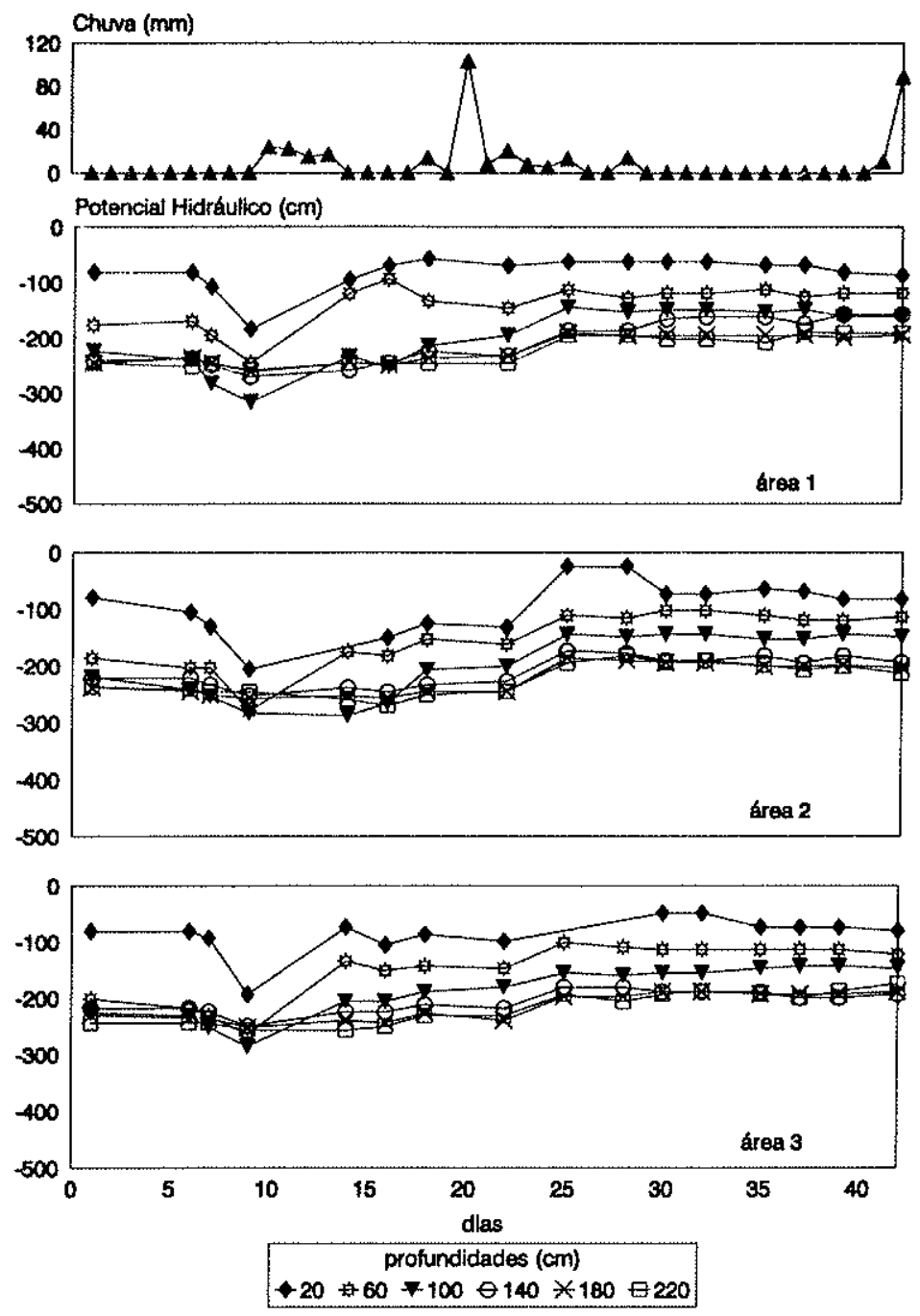

Aplicaçáo de vinhaça no dia 23

Figura 5.4 - Potencial hidráulico na zona não saturada (1/11/89 a 12/12/89)

Os valores de potencial hidráulico observados nas profundidades de 180 e $220 \mathrm{~cm}$ crescem com o decorrer do tempo em virtude da elevação progressiva do nível d'água subterrânea causada pela intensa recarga induzida pelas forte chuvas. Neste período os tensiômetros locados nas profundidades de $220 \mathrm{~cm}$ localizavam-se na zona saturada ou na franja capilar. Os valores de potencial hidráulico obtidos para esta profundidade concordam aproximadamente com os valores de potencial hidráulicos obtidos nos multiníveis, apresentados na figura 5.1.

Na figura 5.5 é apresentada as variações do conteúdo volumétrico de água no tempo para todas as profundidades, nas áreas 1,2 e 3 no primeiro período de medições (período seco).

Nesta figura observa-se que os valores de umidade para as profundidades de 20,60 e $100 \mathrm{~cm}$ são próximos, constantes e baixos, enquanto que os valores observados para as profundidades de 180 
e $220 \mathrm{~cm}$ são também próximos e constantes, mas são altos, próximos ao valor de saturação. Os valores observados para a profundidade de $140 \mathrm{~cm}$ são intermediários.
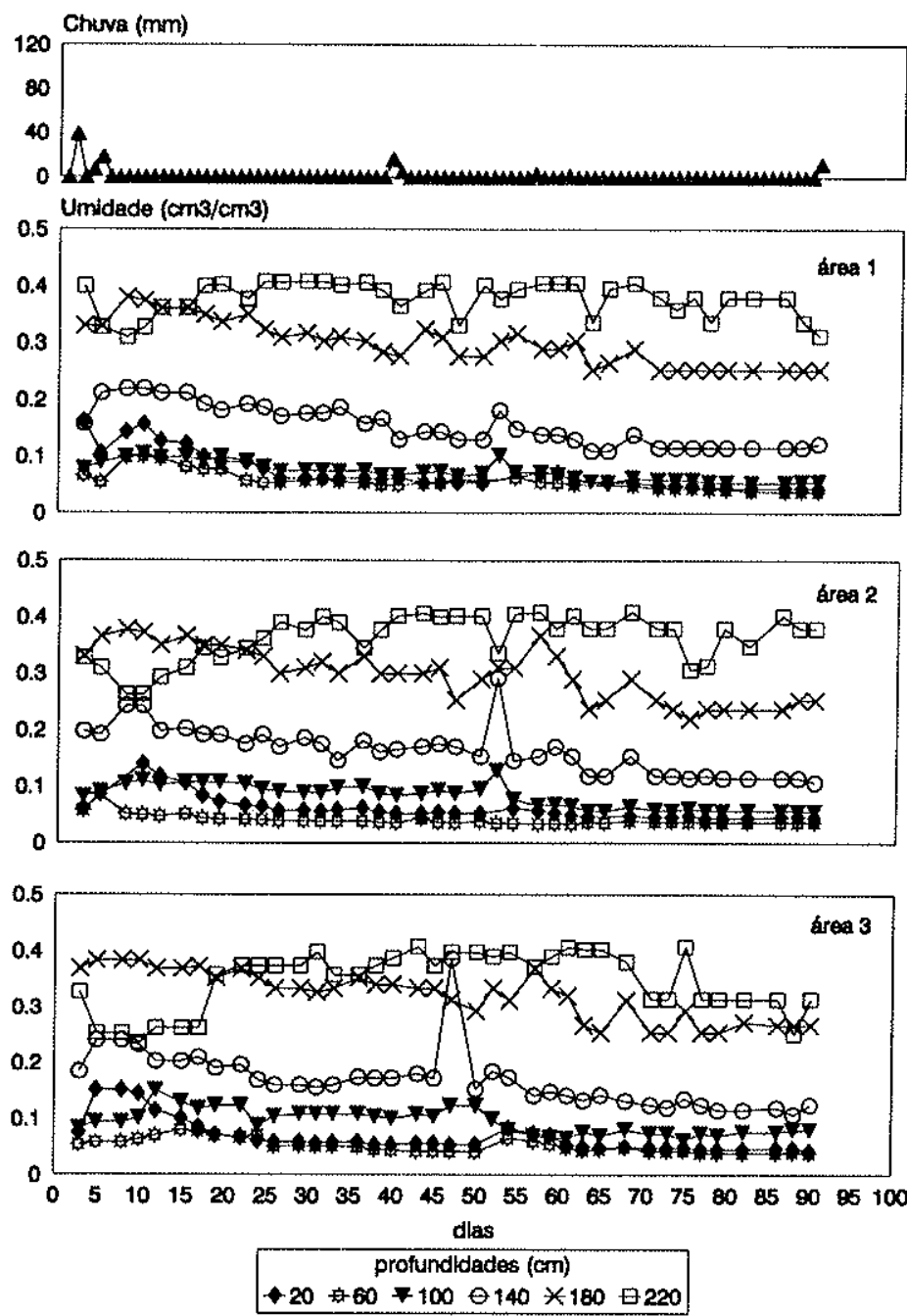

Figura 5.5 - Conteúdo de água na zona não saturada (3/5/89 a 29/7/89)

Este fato demonstra que os valores de conteúdo de água, e consequentemente os valores de fluxo de água, condutividade hidráulica e velocidade de fluxo da água nas profundidades mais rasas são fortemente influenciados pela recarga induzida pelas chuvas e os valores de conteúdo de água para as profundidades maiores são fortemente influenciados pelo posicionamento do nível d'água freático. Este fato pode ser observado também na tabela 1 do anexo 1 .

Na figura 5.6 são apresentadas as variações do conteúdo volumétrico de água para o segundo período de medidas caracterizado por intensa pluviosidade.

Nesta figura, podemos notar um aumento crescente nos valores de conteúdo de água para as profundidades de $20,60,100$ e $140 \mathrm{~cm}$ devido a intensa recarga induzida pelas forte chuvas e os 
valores para as profundidades de 180 e $220 \mathrm{~cm}$, continuam mostrando valores próximos ou iguais aos da saturação.
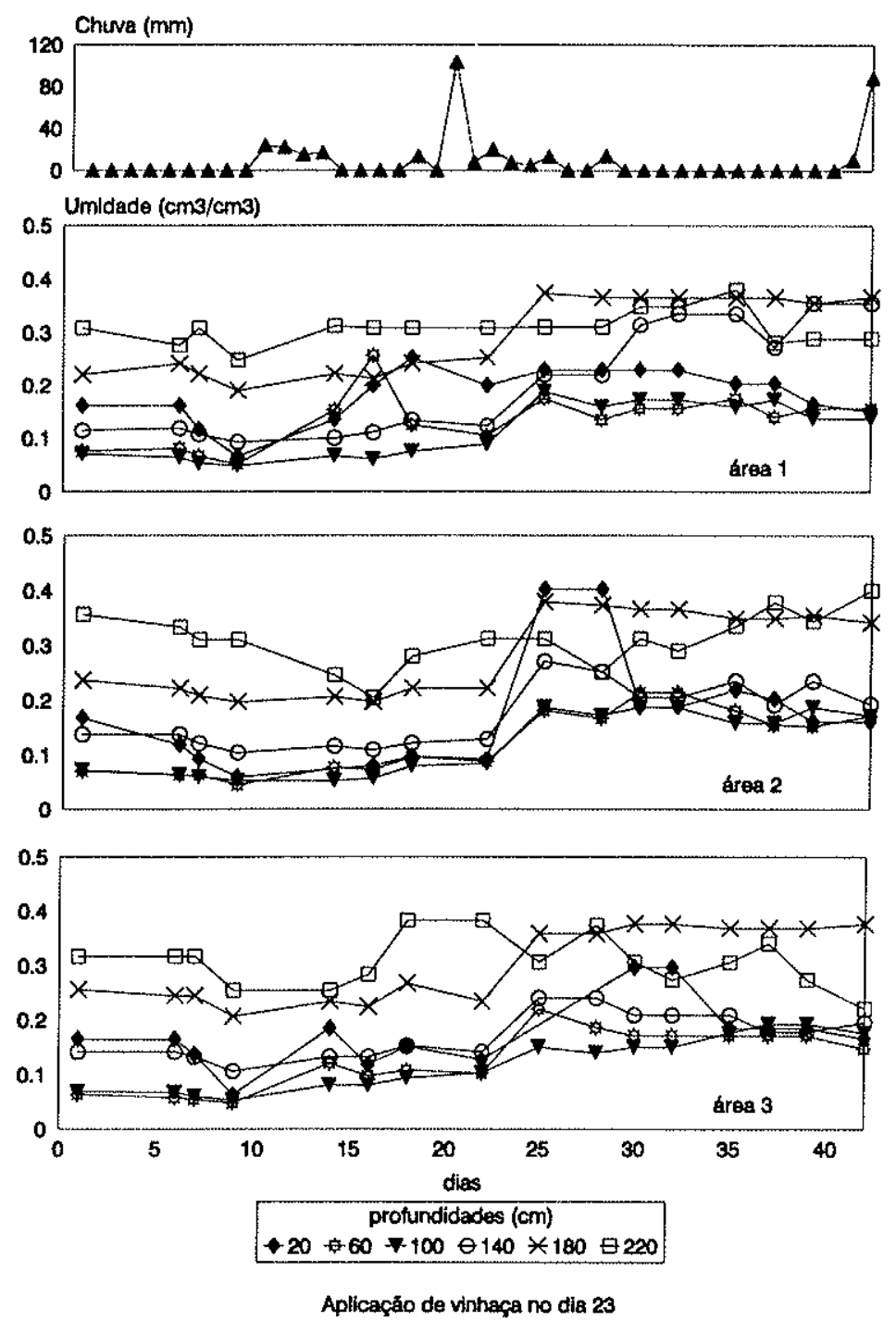

Figura 5.6 - Conteúdo de água na zona não saturada (1/11/89 a 12/12/89)

Comparando as figuras 5.5 e 5.6, nota-se que o conteúdo volumétrico de água das camadas mais próximas da superfície do terreno $(20,60100$ e $140 \mathrm{~cm})$ são menores no período seco, ocorrendo consequentemente valores mais baixos de condutividade hidráulica não saturada, fluxo e velocidade de fluxo da água, conforme pode ser observado nas tabelas 1 e 2 do anexo 1 .

Na figura 5.7, por exemplo, pode-se observar as variações dos valores da condutividade hidráulica na zona não saturada no tempo, nos dois períodos de amostragem, na área 1. Esta figura ilustra a dependência que valores de condutividade hidráulica tem pelos valores de conteúdo volumétrico de água, fornecendo gráficos com formatos semelhantes aos gráficos que mostram as variações de conteúdo de água. 

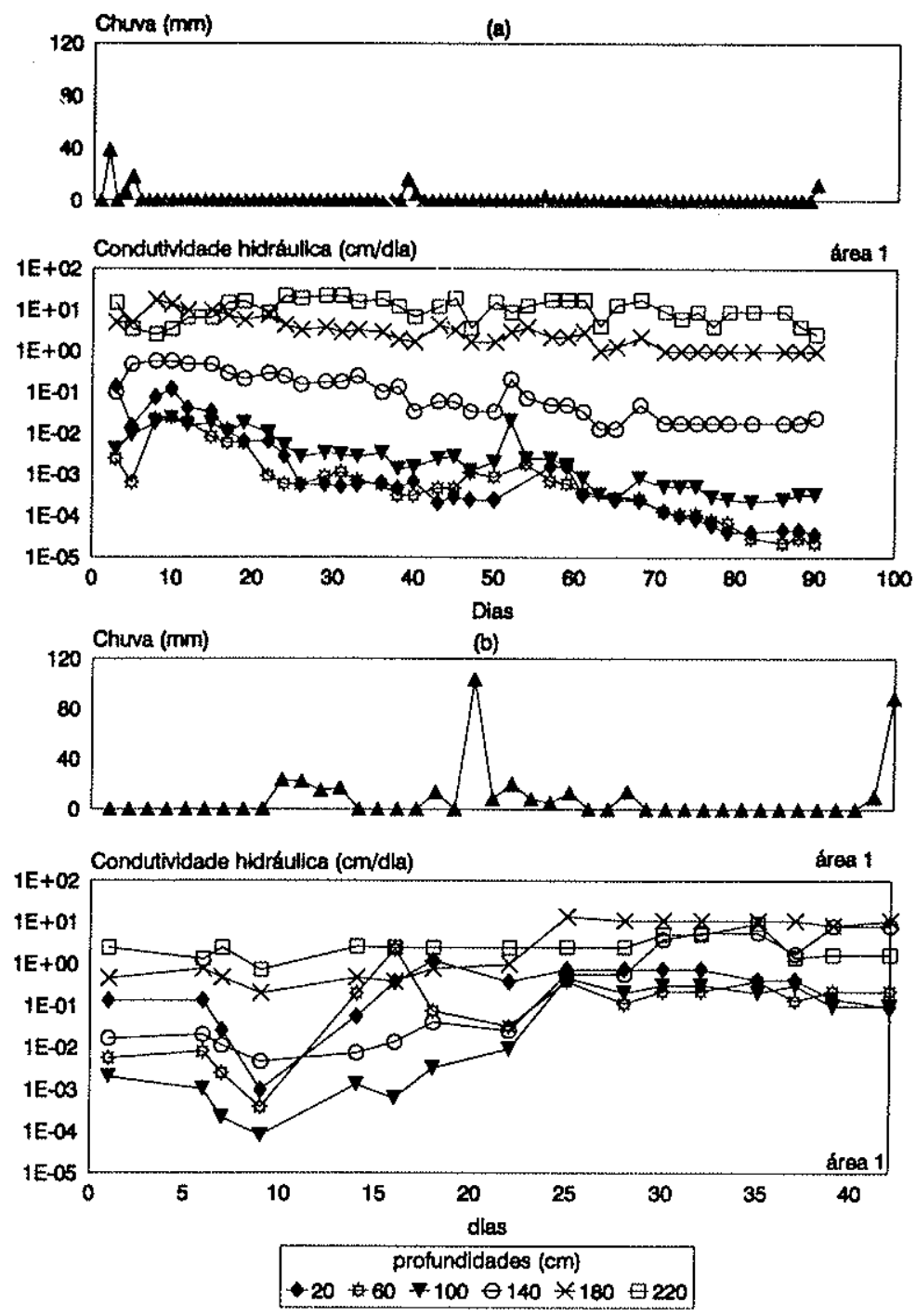

Figura 5.7 - Condutividade hidráulica: (a) 3/05/89 a 29/07/89 e (b) 1/11/89 a 12/12/89

No período seco os valores de condutividade hidráulica para as profundidades de $20,60,100 \mathrm{~cm}$ são baixos e descendentes no tempo, os valores para as profundidades de 180 e $220 \mathrm{~cm}$ são altos e constantes e para a profundidade de $140 \mathrm{~cm}$ os valores são intermediários. No período chuvoso os valores são altos e crescentes para as profundidades de $20,60,100$ e $140 \mathrm{~cm}$ e altos e constantes para as profundidades de 180 e $220 \mathrm{~cm}$. 


\section{3 - Comportamento dos constituintes da vinhaça nas zonas não saturada e saturada}

Antes da aplicação de vinhaça foi realizada, na área de estudo, uma campanha de amostragem de água das zonas não saturada e saturada, e após a aplicação foram realizadas 4 campanhas.

Devido a problemas ocorridos na amostragem, como por exemplo a insuficiência de volume de água coletada nos lisímetros de sucção para análise, e no transporte das amostras até o laboratório foram utilizados, neste estudo, apenas os parâmetros selecionados como prioritários, que apresentaram um número suficiente de resultados de análises permitindo uma interpretação coerente destes. Desta forma os parâmetros utilizados neste estudo foram: cloreto, carbono orgânico dissolvido (COD), sulfato, potássio, nitrogênio amoniacal, nitrogênio Kjeldahl total (NKT) e nitrogênio nitrato.

Os resultados das análises das águas coletadas dos lisímetros foram tratados, sendo calculados os valores médios dos resultados obtidos nas 3 repetições efetuadas por profundidade amostrada. Estes valores médios são apresentados na tabela 3 do anexo 3.

Os resultados referentes às análises químicas das águas coletadas nos poços de monitoramento com filtro longo e nos poços de monitoramento tipo multinível são mostradas na tabela 4 do anexo 3 .

A figura 5.8 mostra a distribuição das concentrações de cloreto das águas coletadas dos lisímetros de sucção antes e após a aplicação da vinhaça.

Nesta e nas demais figuras a seguir as datas de amostragem foram: $22 / 11 / 89$, $13 / 12 / 89,03 / 01 / 90,31 / 01 / 90$ e 15/03/90 que correspondem aos dias $1,22,43,71$ e 114 respectivamente nestas figuras. A aplicação da vinhaça foi realizada no dia 23/11/89 que corresponde ao dia 2.

As concentrações de cloreto na zona não saturada encontradas antes da aplicação da vinhaça (valores de concentração naturais) são bastante baixas. Após a aplicação da vinhaça as concentrações de cloreto aumentaram, nas áreas 1, 2 e 3, atingindo altas concentrações nos dias 43 e 71 , principalmente nas profundidades superiores $(40,80 \mathrm{e}$ $120 \mathrm{~cm}$ ). Com o decorrer do tempo as concentrações de cloreto foram diminuindo atingindo valores próximos aos naturais. 

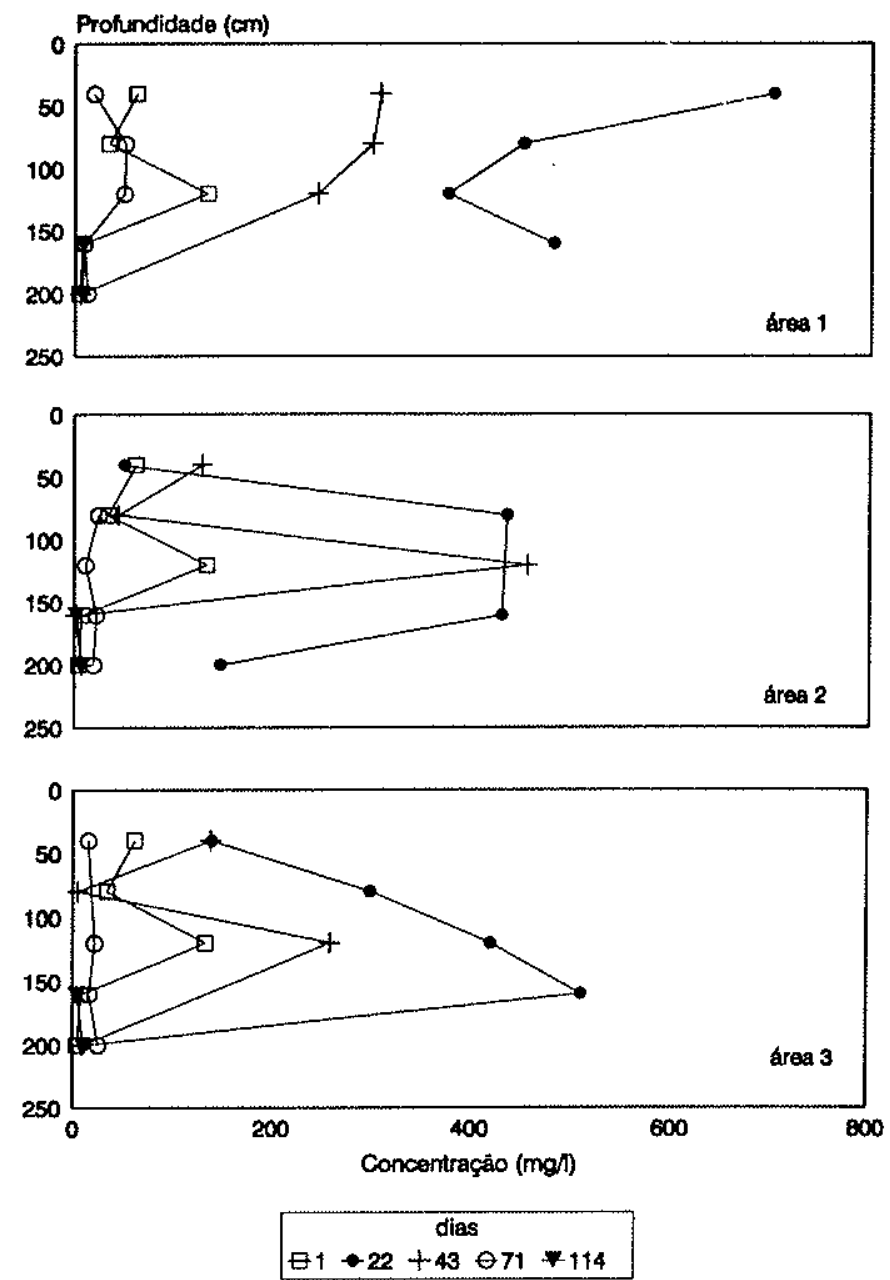

Aplicaçăo da vinhaça no dia 2

Figura 5.8 - Distribuição de cloreto na zona não saturada

Destaca-se novamente que os gradientes de potencial hidráulico, o conteúdo volumétrico de água e a condutividade hidráulica apresentavam, nesta ápoca, altos valores, e consequentemente o fluxo e velocidade da água e consequentemente de solutos eram altos e predominantemente descendente, conforme ilustra a figura 5.4.

Nas áreas 1, 2 e 3 foram observadas tendências semelhantes na distribuição das concentrações de cloreto na zona não saturada embora tenham sido aplicadas diferentes quantidades de vinhaça. $\mathrm{Na}$ área 2, por exemplo, não foi aplicada vinhaça mas mesmo assim foram observadas variações nas concentrações de cloreto nas águas coletadas nos lisímetros instalados nesta área. Provavelmente as diferentes quantidades de vinhaça aplicadas na área de estudo induziram um aumento dos gradientes de potencial hidráulico no sentido horizontal gerando fluxo de água e de solutos lateral. 
A figura 5.9 mostra a distribuição das concentrações de cloreto na zona saturada, obtidas através da realização de análises químicas efetuadas em amostras de água coletadas nos poços de monitoramento tipo multinível.

Os valores de concentração de cloreto, assim como para os demais parâmentros, antes da aplicação da vinhaça (dia 1), foram obtidos através da análises de água coletadas nos poços de monitoramento com filtro longo, sendo considerados como valores naturais, a média dos resultados obtidos.
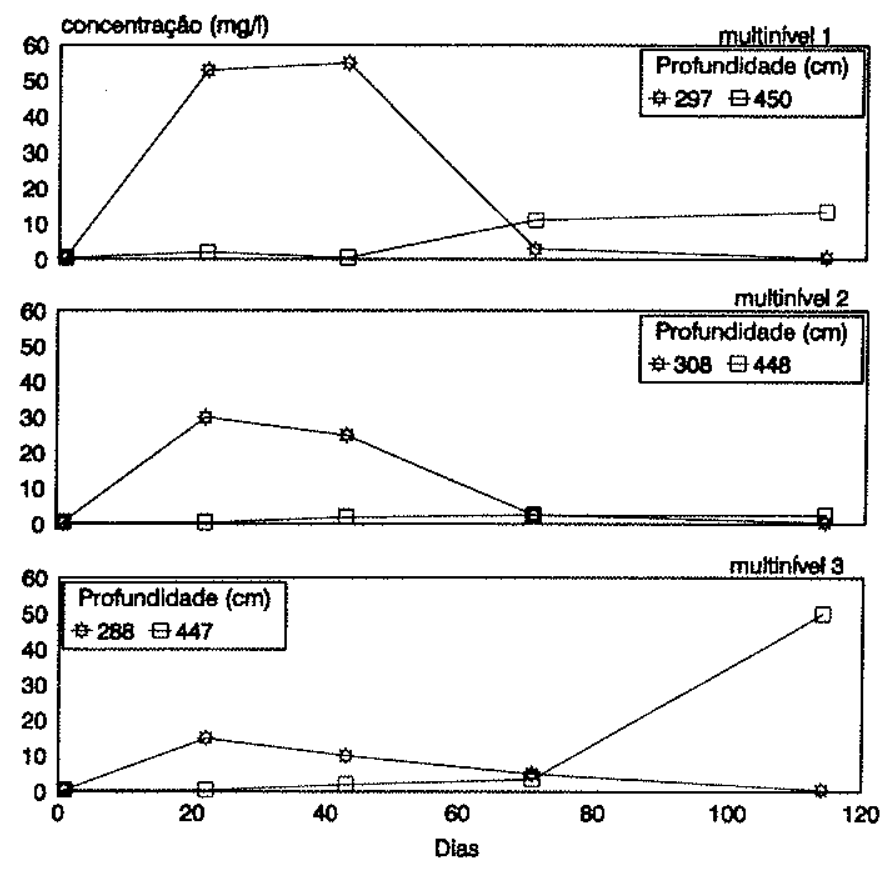

Aplicaçáo da vinhaça no dia 2

Figura 5.9 - Distribuição de cloreto na zona saturada

A concentração natural de cloreto nas águas da zona saturada é bastante baixa. Após a aplicação da vinhaça observou-se, nos dias 22 e 43, um grande aumento nas concentrações de cloreto das águas coletadas dos poços mais rasos dos multiníveis 1 , 2 e 3 . Nos dias 71 e 114 as concentrações voltaram a apresentar valores próximos aos naturais. As concentrações das águas coletadas nos poços mais profundos dos multiníveis apresentaram alterações significativas a partir do dia 43, nas áreas 1 e 3.

Estas observações indicam que o cloreto, que se encontrava na vinhaça aplicada com concentração de $673 \mathrm{mg} /$, migrou pela zona não saturada, onde predominavam condições de fluxo de água e solutos descendentes, atingindo o nível superior da zona saturada, onde predominavam condições de fluxo de água horizontal (conforme ilustra a figura 5.1), aumentando significativamente os valores das concentrações de cloreto. 
O nível inferior da zona saturada investigado mostrou alterações nos valores de concentração posteriormente (a partir do dia 43), provavelmente pelo cloreto proveniente da vinhaça aplicada na parte localizada a montante da área de estudo.

Em geral, as concentrações observadas na zona saturada são menores que as observadas na zona não saturada em função do efeito provocado pelos fenômenos conjugados da dispersão e difusão ocorridos nestas zonas. Deve-se destacar que o cloreto não sofre adsorção.

Na figura 5.10 é apresentada a distribuição das concentrações de COD (carbono orgânico dissolvido) nas águas coletadas dos lisímetros de sucção das áreas 1,2 e 3.
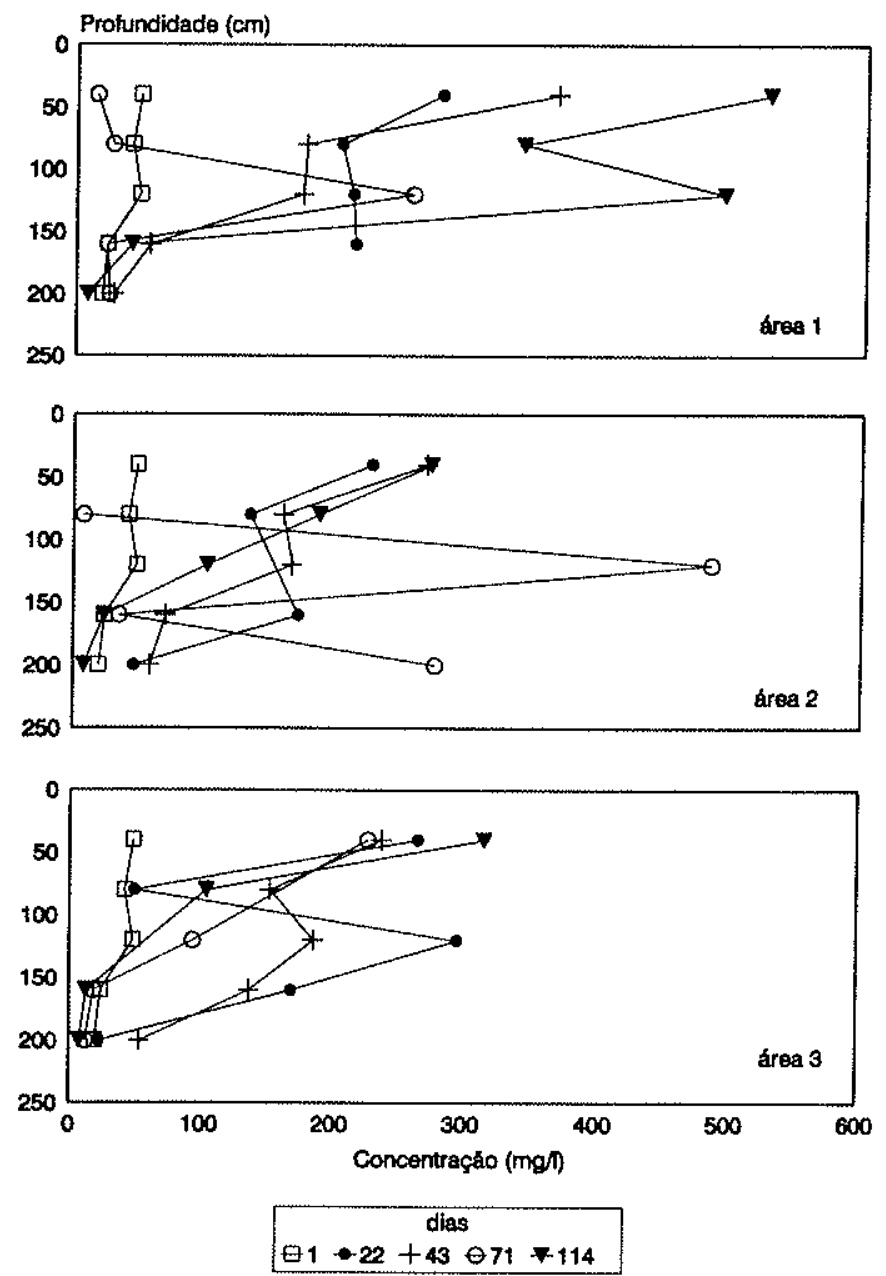

Aplicaçăo da vinhaça no dia 2

Figura 5.10 - Distribuição de COD na zona não saturada

A concentração de COT (carbono orgânico total) na vinhaça aplicada era de $21.450 \mathrm{mg} / 1$ (média). Nota-se que as concentrações de COD, na figura 5.10 , variam, 
ocorrendo diminuição nos valores com o tempo, embora em alguns casos, principalmente nas profundidades mais rasas $(40,80$ e $120 \mathrm{~cm})$ ocorram aumentos ou manutenção dos valores. Estes fatos indicam que provavelmente uma parte dos compostos orgânicos ficaram temporariamente adsorvidos na zona não saturada, ou sofreram processo de degradação, migrando posteriormente para a zona não saturada com retardamento. Outra parte provavelmente composta por compostos orgânicos mais móveis migraram diretamente para a zona saturada, conforme é observado na figura 5.10, área 1.

Provavelmente a capacidade de adsorção, complexação na fração húmica e os processos biológicos de degradação na zona não saturada não foram capazes de reter a grande quantidade de COD aplicada na zona não saturada. Com a aplicação da vinhaça ocorre inicialmente uma rápida atividade microbiana, que promove um consumo elevado de oxigênio, favorecendo processos anaeróbios de degradação do COD. Nestes processos anaeróbios o COD é consumido lentamente, ficando desta forma disponível para transporte na zona não saturada. Os processos anaeróbios podem ter sido acentuados devido à alta pluviosidade no período de estudo.

$\mathrm{Na}$ figura 5.11 é apresentada a distribuição das concentrações de COD das águas subterrâneas coletadas nos poços de monitoramento tipo multinível.
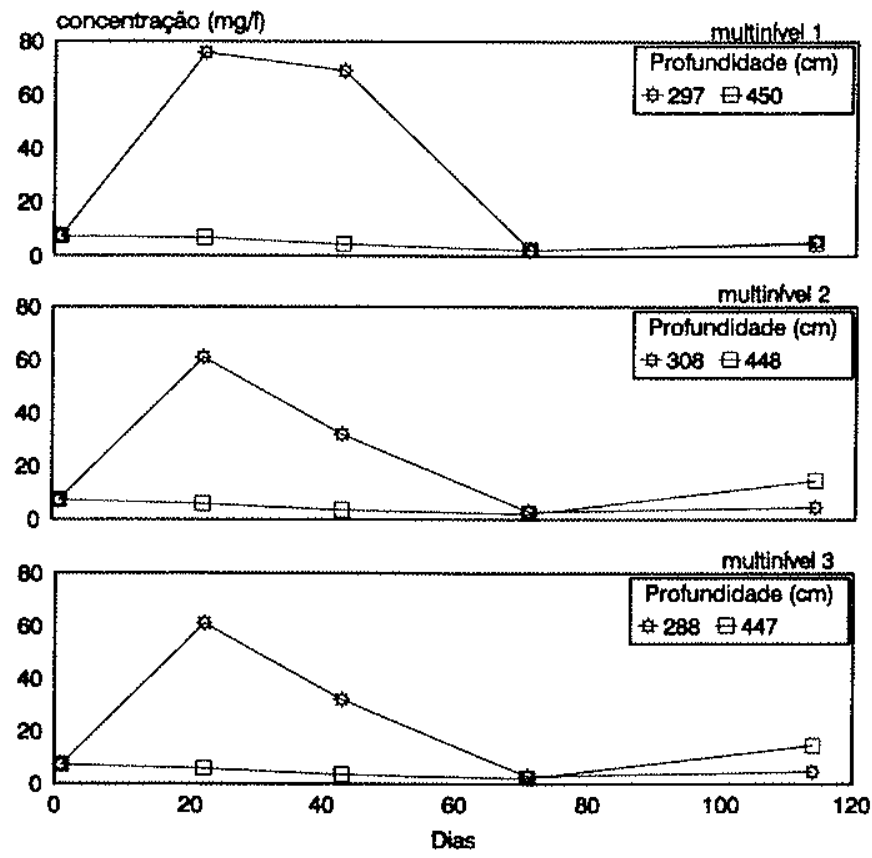

Aplicacáo da vinhaga no dia 2

Figura 5.11 - Distribuição de COD na zona saturada 
Na zona saturada as concentrações de COD distribuem-se de forma semelhante à observada para o cloreto. Observa-se nesta figura que existe um aumenio na concentração de COD significativo, após 20 dias da aplicação de vinhaça, indicando que o excesso de COD que não foi adsorvido ou degradado na zona não saturada, atingiu a zona saturada alterando suas características naturais.

A distribuição de sulfato nas zonas não saturada é apresentada na figura 5.12. Embora não tenham sido obtidos os resultados das análises de sulfato para todas as datas de amostragem, podemos observar concentrações elevadas de sulfato na zona não saturada.
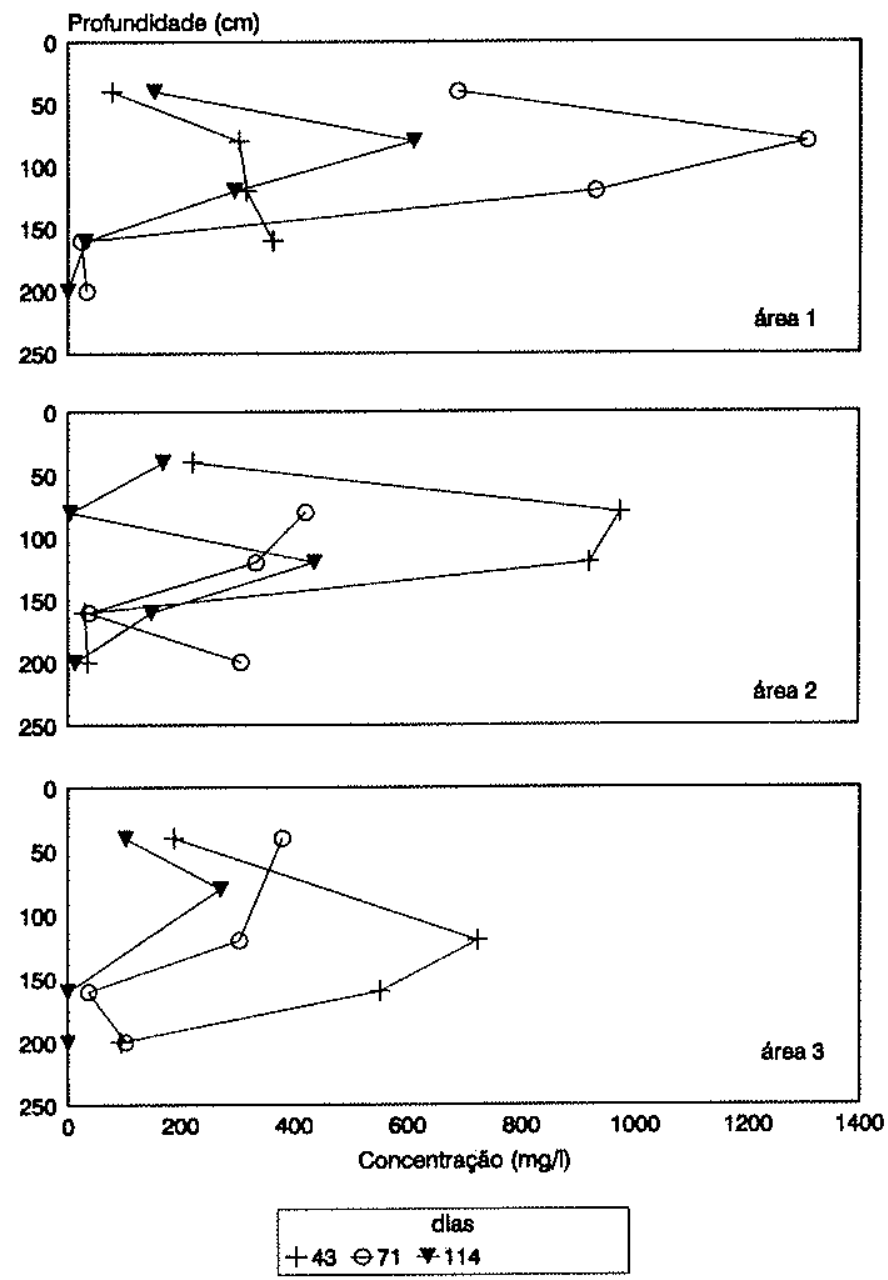

Aplicação da vinheça no dla 2

Figura 5.12 - Distribuição de sulfato na zona não saturada

A concentração de sulfato observada na vinhaça foi de $841 \mathrm{mg} / \mathrm{l}$ (média). Nas áreas 1 e 2 foram observadas concentrações maiores que esta, indicando a ocorrência de prováveis reações químicas e/ou biológicas geradoras de sulfato. No ciclo do enxofre 
as principais transformações geradoras de sulfato na zona não saturada são decorrentes da atividade microbiana. Provavelmente parte do sulfato foi absorvido pela cana e parte ficou disponível para lixiviação. De acordo com CASARINI (1989) a adição de vinhaça na zona não saturada promove o aumento do $\mathrm{pH}$. Segundo COSTA (1980) o aumento de $\mathrm{pH}$ determina menor adsorção de sulfato o que pode explicar os elevados teores de sulfato observados na zona saturada

Na figura 5.13 são apresentadas as variações dos valores de concentração de sulfato na zona saturada. Foram observadas elevados concentrações de sulfato, principalmente na área 1, nas águas coletadas nos poços mais rasos dos multiníveis, após a aplicação de vinhaça, confirmando as observações efetuadas acima.
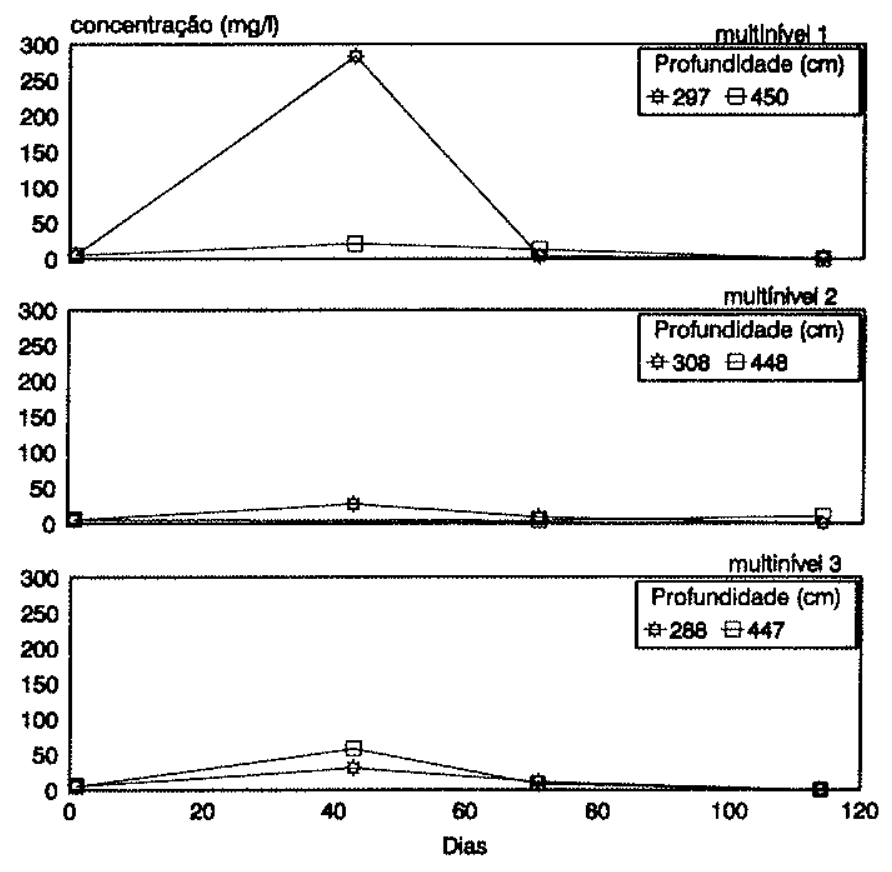

Aplicaçăo da vinhaça no dia 2

Figura 5.13 - Distribuição de sulfato na zona saturada

Não foram observadas variações significativas nas concentrações observadas nos poços mais profundos dos multiníveis, provavelmente devido a adsorção.

Na figura 5.14 é apresentada a distribuição das concentrações de potássio obtidas das análises de água coletadas dos lisímetro de sucção. 

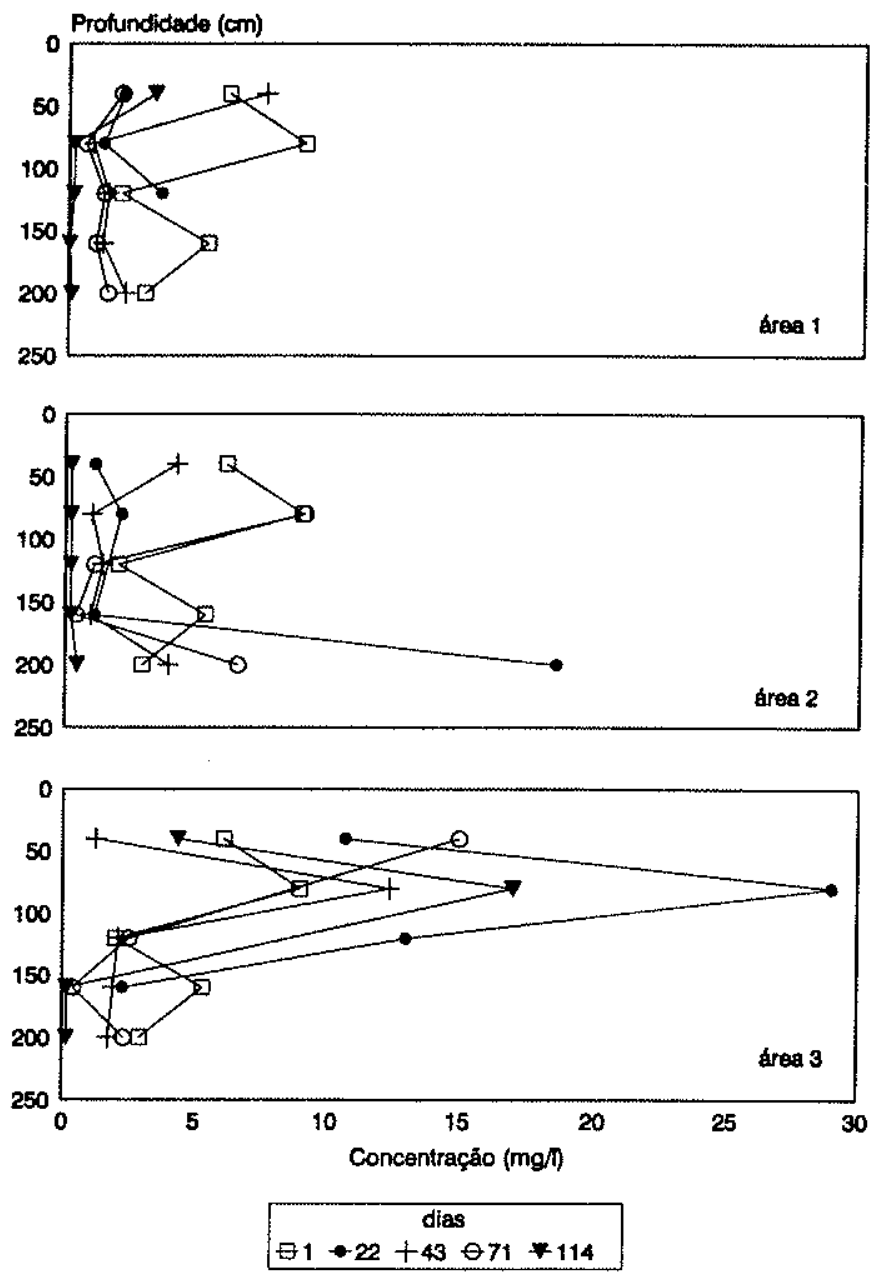

Aplicacăo da vinhaça no dia 2

Figura 5.14 - Distribuição de potássio na zona não saturada

Embora a concentração de potássio na vinhaça fosse elevada, $1.200 \mathrm{mg} / \mathrm{l}$, nas áreas $1 \mathrm{e}$ 2 , as concentrações observadas após a aplicação da vinhaça são próximas ou menores aos valores naturais, indicando que o potássio foi retirado da zona não saturada provavelmente pela cana. $\mathrm{Na}$ área 3 observa-se maiores valores de potássio, principalmente na profundidade de $80 \mathrm{~cm}$, que decrescem com o tempo, indicando a que a taxa de aplicação de vinhaça de $300 \mathrm{~m}^{3} /$ ha possuia uma quantidade de potássio superior às necessidades nutricionais da cana, ficando o potássio excedente disponível para outros processos físicos como adsorção e/ou lixiviação.

Na figura 5.15 é apresentada a distribuição das concentrações de potássio na zona saturada. 

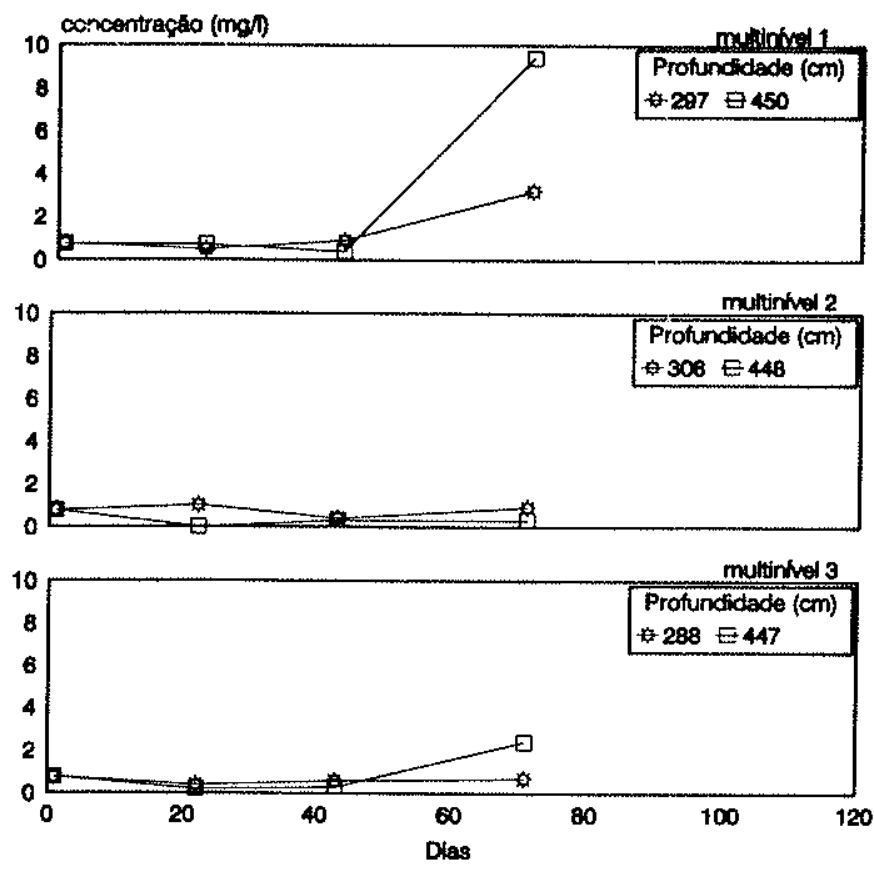

Aplicaçăo da vinhaça no dia 2

Figura 5.15 - Distribuição de potássio na zona saturada

Não foram observados aumentos significativos na concentração de potássio nas águas da zona saturada. Somente na última amostragem pode-se observar um aumento nas concentrações de potássio nas duas profundidades de instalação dos poços multinível 1 e 3 .

O potássio proveniente da aplicação da vinhaça foi, em sua maior parte, consumido pela cana e/ou retido por adsorsão na zona não saturada, conforme observado na figura 5.14 .

Uma pequena parte deste potássio, que ficou adsorvida na zona não saturada pode ter sido desorvida e, após as grandes chuvas ocorridas, chegou a zona saturada, alterando a qualidade das águas desta. Entretanto os valores observados de potássio na zona saturada são baixos.

Na figura 5.16 é apresentada a distribuição de nitrogênio amoniacal na zona não saturada. A concentração de nitrogênio amoniacal na vinhaça aplicada era de $11 \mathrm{mg} / \mathrm{l}$. 

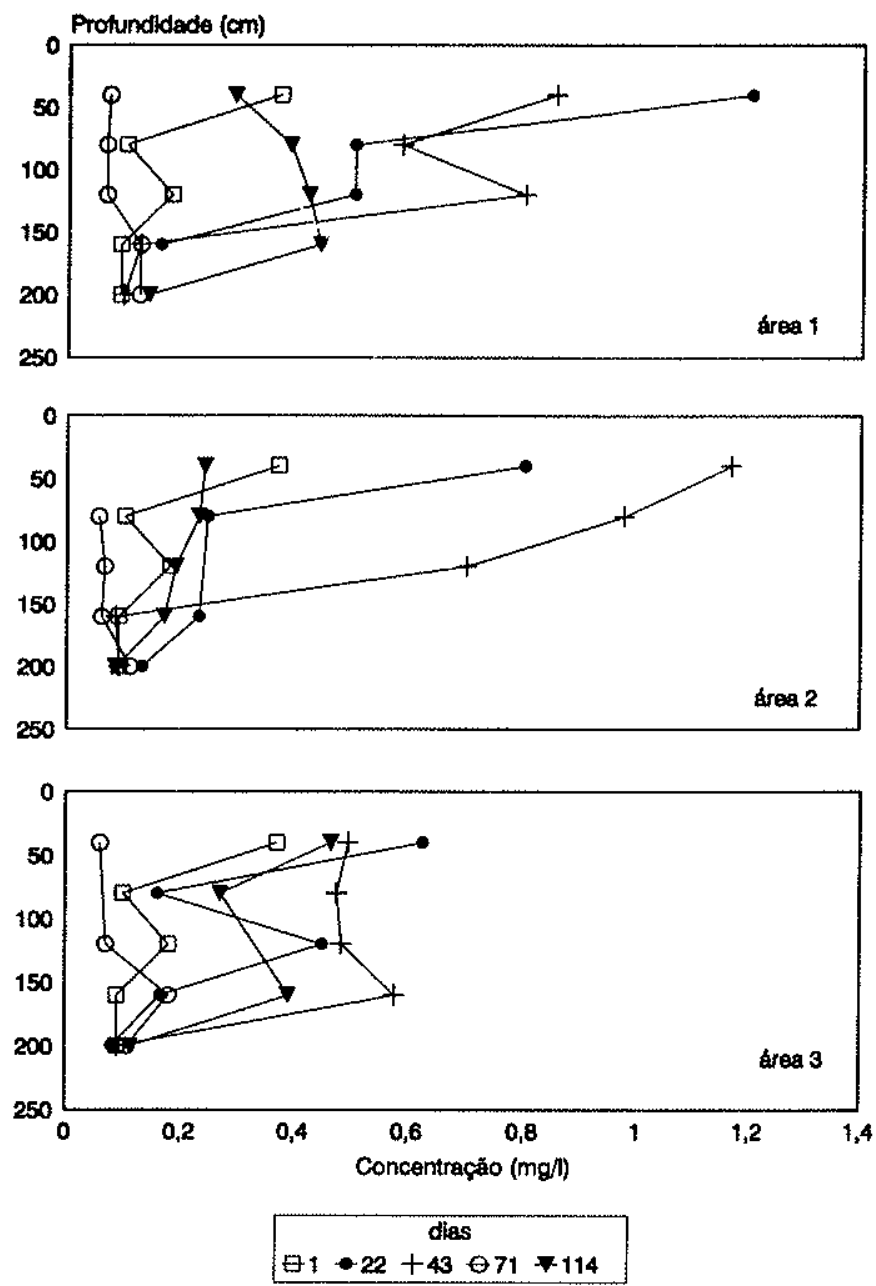

Aplicaçáo da vinhaça no dia 2

Figura 5.16 - Distribuição de nitrogênio amoniacal na zona não saturada

Considerando-se que a vinhaça possue baixas concentrações de nitrogênio as concentrações nas formas amoniacal e nítrica permaneceram baixas após a aplicação da vinhaça, tanto na zona não saturada quanto na saturada.

Na figura 5.17 é apresentada a distribuição das concentrações de nitrogênio amoniacal na zona saturada.

Foram observadas pequenas alterações nos valores de concentração de nitrogênio amoniacal para as amostras de água coletadas no nível mais raso dos multiníveis. Estas alterações foram provocadas provavelmente pela mineralização do nitrogênio orgânico que atingiu a zona saturada, conforme observado na figura 5.19 apresentada a seguir. 

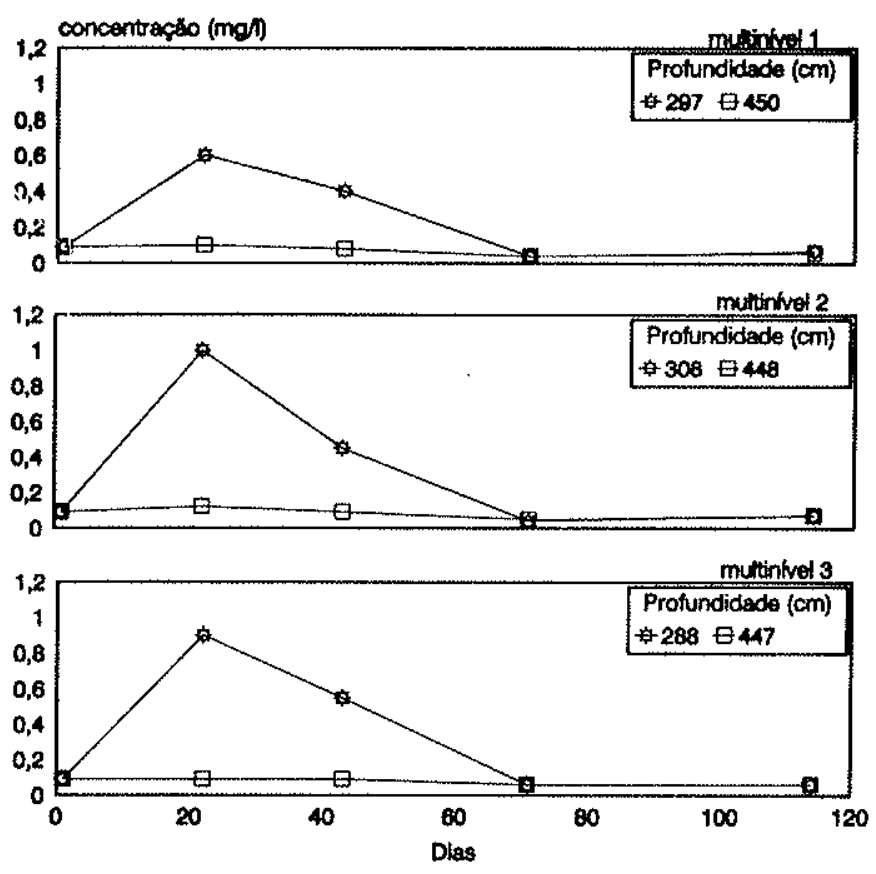

Aplicaçáo da vinhaça no dia 2

Figura 5.17 - Distribuição de nitrogênio amoniacal na zona saturada

A distribuição das concentração de nitrogênio Kjeldahl total na zona não saturada é apresentada na figura 5.18. A concentração deste parâmetro na vinhaça aplicada era de $135 \mathrm{mg} / \mathrm{l}$. Os principais constituintes do NKT são compostos orgânicos nitrogenados.

Os valores observados nesta figura mostram uma semelhança à tendência apresentada pelo parâmetro COD, indicando provavelmente que as formas orgânica e amoniacal encontradas na zona não saturada são resultantes dos processos de mineralização da matéria orgânica.

Na figura 5.19 podemos observar as variações das concentrações de NKT na zona saturada.

As concentrações observadas de NKT mostraram altos valores nos níveis superiores dos poços multinível, principalmente na área 2.

A distribuição das concentrações de nitrogênio nitrato na zona não saturada é apresentada na figura 5.20. A concentração observada na vinhaça aplicada era de $0,08 \mathrm{mg} / \mathrm{l}$ (média). Os valores de concentração natural de nitrogênio nitrato apresentadas nesta figura são extremamente baixos. 

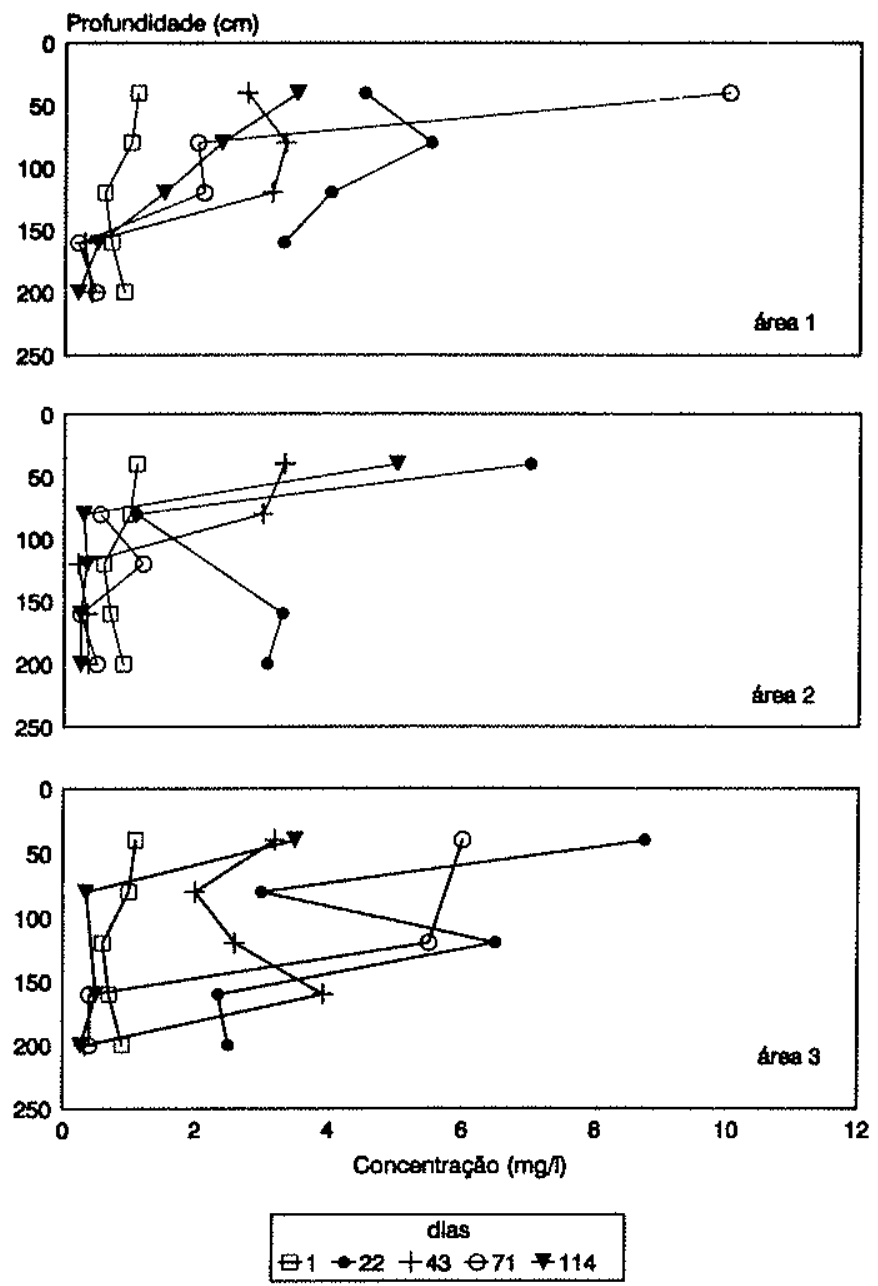

Apllcaçăo da vinhaça no dia 2

Figura 5.18 - Distribuição de NKT na zona não saturada

As variações das concentrações de nitrogênio nitrato observadas indicam um processo pouco intenso de nitrificação, a partir do nitrogênio amoniacal mineralizado do nitrogênio orgânico presente na vinhaça.

Na figura 5.21 são apresentadas as variações das concentrações de nitrogênio nitrato na zona saturada.

Não foram observadas aumentos significativos nas concentrações de nitrogênio nitrato em relação aos valores naturais observados na zona saturada.

Em função do reduzido número de amostragens realizadas, do grande intervalo entre estas amostragens e à ausência de uma avaliação detalhada do fluxo de água na zona não saturada na direção horizontal, além da ausência de uma avaliação dos fluxos preferenciais ou fluxo por macroporos na zona não saturada a análise do transporte dos constituintes nas zonas não saturada 
e saturada não pode ser realizado de forma quantitativa. Os dados apresentados foram interpretados de forma qualitativa efetuando-se comparações entre os valores de concentração dos parâmetros observados na vinhaça e nas zonas não saturada e saturada.
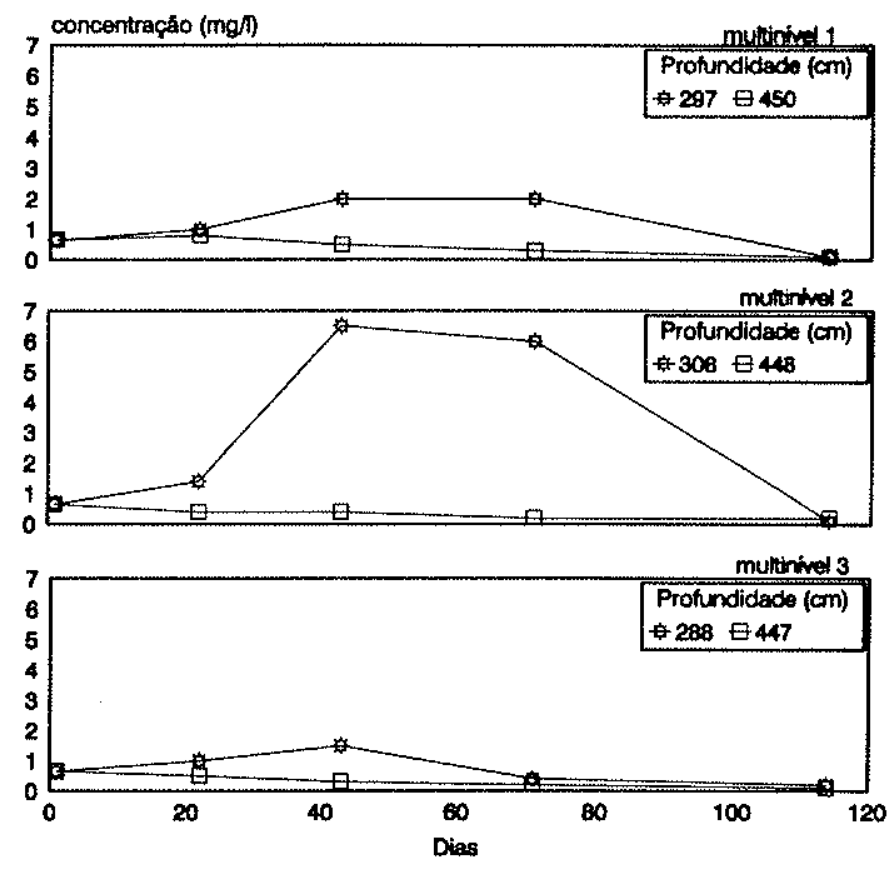

Aplicaçáo da vinhaça no dla 2

Figura 5.19 - Distribuição de NKT na zona saturada

De acordo com os resultados obtidos o desempenho dos equipamentos de monitoramento pode ser avaliado como aceitável, de uma maneira geral, permitindo uma descrição lógica do fluxo da água e dos constituintes da vinhaça pelas zonas não saturada e saturada.

Os poços de monitoramento com filtro longo foram úteis na observação das variações do nível d'água freático e para medidas de potencial hidráulico para a confecção de mapas potenciométricos visando definir os sentidos de fluxo das águas subterrâneas locais. Este último objetivo tornou-se válido após a confirmação, obtida através de medições efetuadas nos poços de monitoramento tipo multinível, de que o fluxo das águas subterrâneas locais era horizontal.

As análises químicas efetuadas nos poços com filtro longo não apresentaram uma resposta coerente quanto ao comportamento dos constituintes da vinhaça em profundidade, conforme pode ser observado na tabela 4 do anexo 3 .

Os poços de monitoramento tipo multinível com filtros curtos demostraram ser muito eficientes na determinação de dados puntuais de potencial hidráulico e também nas determinações de valores puntuais das concentrações dos parâmetros analisados. Poderiam ter sido instalados um 
maior número de poços tipo multinível para se ter uma melhor avaliação do fluxo das águas subterrâneas e do transporte dos constituintes da vinhaça, tanto no sentido horizontal quanto no vertical, mas em função de problemas em campo não foi possível executar esta tarefa.
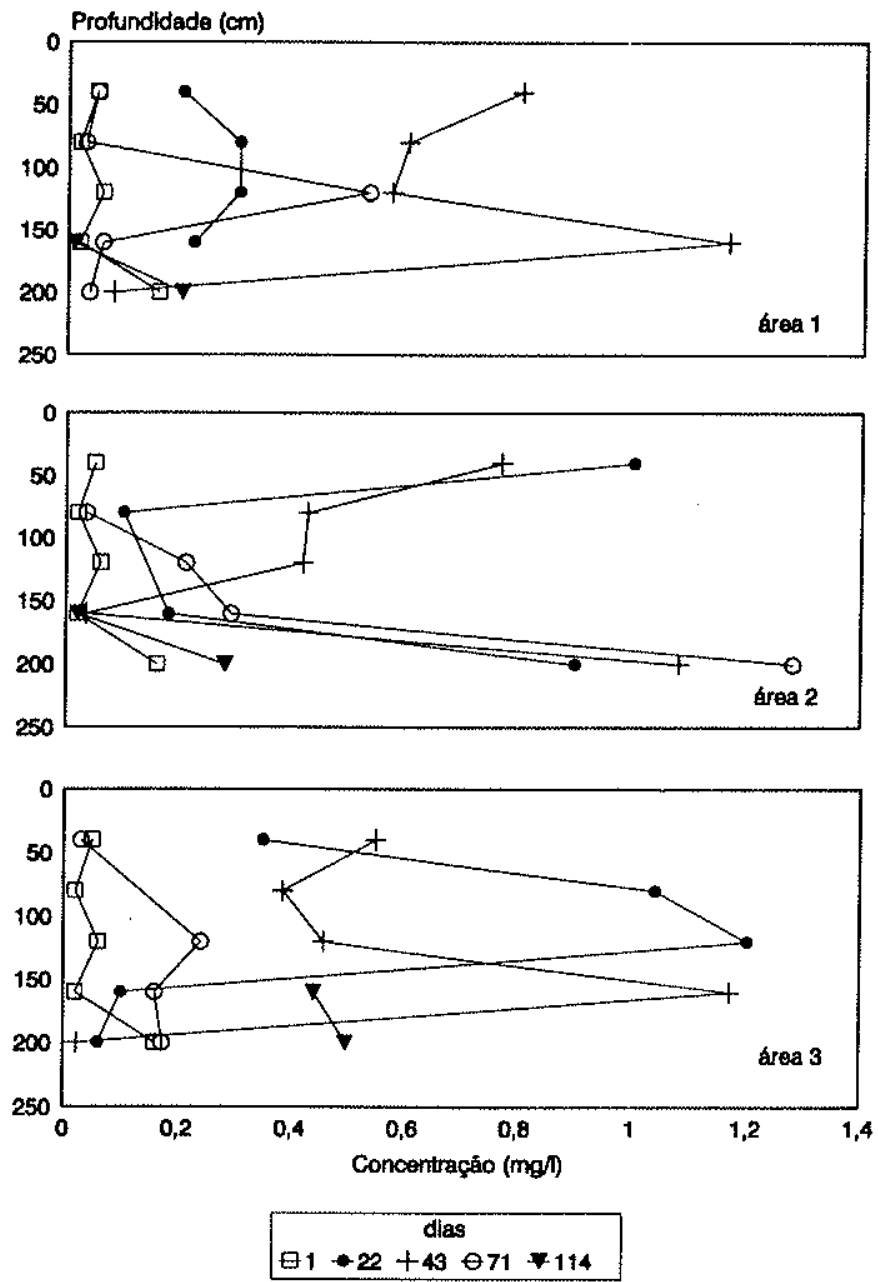

Aplicaçăo da vinhaça no dla 2

Figura 5.20 - Distribuição de nitrogênio nitrato na zona não saturada

Os lisímetros de suç̧ão mostraram-se muito eficientes para a coleta de amostras de água da zona não saturada. Entretanto o tamanho da câmara de pressão-vácuo poderia ter sido maior para permitir a coleta de um volume maior de amostras de água a fim de se analisar um número maior de parâmetros. Poderiam também ser instalados um maior número de lisímetros a fim de se avaliar o transporte dos constituintes da vinhaça no sentido horizontal.

Os tensiômetros com manômetros de mercúrio foram muito eficientes na determinação dos valores de potencial matricial permitindo a realização de várias determinações referents ao fluxo de água na zona não saturada. Entretanto estes equipamentos necessitam de trabalhos intensos de manutenção para que seus resultados sejam confiáveis, além de não ser recomendado atualmente 
o uso de manômetros de mercúrio devido a riscos de contaminação ambiental. Também poderiam ser instalados em maior número com o objetivo de se avaliar o fluxo de água na direção horizontal.
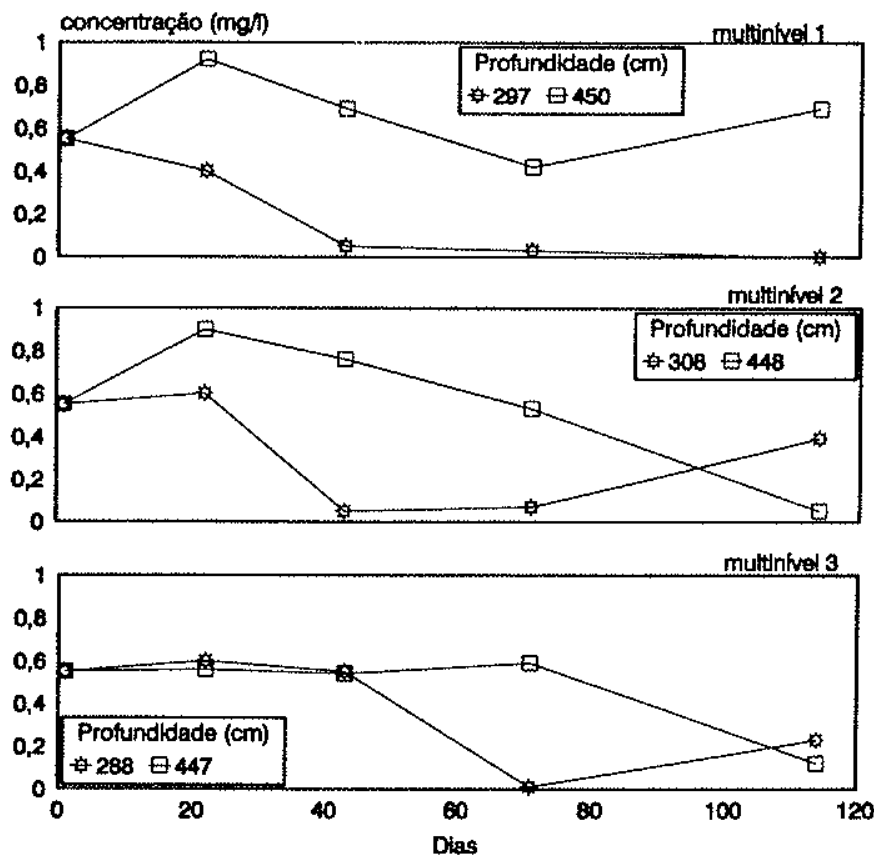

Aplicaçăo da vinhaça no dla 2

Figura 5.21 - Distribuição de nitrogênio nitrato na zona saturada

Os panlisímetros instalados na área não apresentaram resultados em número suficientes devido ao pequeno volume de água coletada nestes equipamento, razão pela qual os resultados referentes a estes equipamentos não foram apresentados. Desta forma o fluxo preferencial ou fluxo por macroporos na zona não saturada não pode ser avaliado neste estudo. 


\section{6- CONCLUSÕES}

Os dados obtidos referentes ao fluxo de água na zona não saturada indicaram que existem dois padrões de fluxo: o primeiro que ocorre durante períodos de baixa pluviosidade e o segundo que ocorre durante os período de baixa pluviosidade.

O primeiro padrão de fluxo caracteriza-se pelos baixos valores de conteúdo de água nas profundidades mais próximas da superfície, fato que gera pequenos gradientes de potencial hidráulico entre estas profundidades. Consequentemente os valores de condutividade hidráulica não saturada, os valores de fluxo de água ou velocidade de Darcy, que pode ser descendente ou ascendente, e a velocidade da água na zona não saturada são baixos.

No segundo padrão de fluxo o conteúdo volumétrico de água é maior gerando maiores gradientes de potencial hidráulico entre as profundidades mais superficiais e um aumento dos valores de condutividade hidráulica não saturada. Consequentemente ocorrem altos valores de fluxo de água na zona não saturada, predominantemente descendente, além de valores mais altos de velocidade de fluxo de água nesta zona, comparado com o período seco.

O conteúdo volumétrico de água, os gradientes de potencial hidráulico, o fluxo e a velocidade da água das camadas mais profundas da zona não saturada, para os dois padrões de fluxo, é condicionado pelo posicionamento do nível d'água subterrânea.

Quanto a qualidade das águas das zonas não saturada e saturada, notaram-se alterações nos valores dos parâmetros analisados na zona não saturada e para alguns parâmetros na zona saturada após a aplicação da vinhaça.

Os resultados obtidos nas análises químicas demonstram que os parâmetros COD, cloreto, carbono orgânico (nitrogênio Kjeldahl total), nitrogênio amoniacal e sulfato, atingiram as águas subterrâneas causando alterações nos seus valores naturais, após a aplicação da vinhaça. Desta forma, estes parâmetros, devido ao fato constatado de que podem atingir a zona saturada e alterar suas características naturais de qualidade de água, deveriam ser considerados na decisão de definição de taxas de aplicação da vinhaça, com o intuito de não alterar as características naturais das águas subterrâneas.

O potássio, elemento utilizado normalmente para definir as taxas de aplicação da vinhaça, e o nitrogênio nitrato não determinaram alterações significativas na qualidade das águas da zona saturada neste estudo. 
Como a cana é uma planta com elevado metabolismo energético, consumindo elevadas quantidades de nitrogênio e potássio, os parâmetros a sereñ monitorados em uma pesquisa de avaliação da vulnerabilidade das águas subterrâneas deverão contemplar não somente o potássio e o nitrato, mais também todos os íons necessários para uma análise completa dás águas subterrâneas, com o objetivo de definir suas características hidrogeoquímicas e as prováveis modificaçĭes causadas pela aplicação de vinhaça em sistemas de fertirrigação.

Deve-se considerar, que através deste estudo, foi constatado que os sedimentos da Formação Botucatu apresentam baixa capacidade de retenção de água na zona não saturada $\mathrm{e}$ consequentemente possuem alta capacidade de transporte dos constituintes da vinhaça analisados por esta zona. Deve-se destacar que o fenômeno de adsorção observado é passageiro, podendo ocorrer a liberação e lixiviação dos constituintes adsorvidos após grandes precipitações pluviométricas. Além disso foi verificado que a zona saturada apresenta altos valores de velocidade das águas subterrâneas indicando consequentemente veloz espalhamento dos constituintes da vinhaça nas águas subterrâneas, caso estes atinjam esta zona. Desta forma, a área de afloramento da Formação Botucatu mostra-se extremamente vulnerável à mudanças nas características naturais das águas subterrâneas, devido à aplicação da vinhaça por fertirrigação.

Embora o estudo do fluxo de água e transporte dos constituintes da vinhaça sejam bastante complicados em função das inúmeras variáveis envolvidas, assim como a dependência dos valores de condutividade hidráulica não saturada pelo conteúdo volumétrico de água, além de vários fenômenos que ocorrem nesta zona como a histerese e os fluxos preferenciais ou fluxo por macroporos, os equipamentos de monitoramento das zonas não saturada e saturada utilizados neste estudo forneceram uma avaliação qualitativa razoável do fluxo de água e transporte de soluto tanto nas zonas não saturada quanto na zona saturada.

Portanto, destaca-se a necessidade de novas pesquisas que analisem a questão do fluxo de água e transporte de todos os constituintes da vinhaça, que possam colocar em risco a qualidade das zonas não saturada e saturada, de forma detalhada e quantitativa, com vistas a determinação de taxas de aplicação de vinhaça, que levem em consideração não somente as necessidades nutricionais da cana, mas principalmente ao uso e a vulnerabilidade à poluição das águas subterrâneas. Estas pesquisas devem ser realizadas em diferentes tipos de material pedológicogeológico, em áreas submetidas a longos períodos de aplicação de vinhaça, visando a proteção dos principais aquíferos do Estado de São Paulo. 


\section{7- REFERÊNCIAS BIBLIOGRÁFICAS}

ANDERSON, L. D. Problems interpreting samples taken with large-volume, falling-suction soil water Samplers. Ground Water, Dublin, 24 (6): 761-769, nov./ dec. 1986.

BASOKUR, A.T. IPES 3 - Interpretation package for eletrical sounding data. ANKARA UNIVERSITESI, 1990.

BALLESTERO, T.; HERZOG, B.; EVANS, O.D.; THOMPSON, G. Monitoring and sampling the vadose zone. In: NIELSEN, M.N., ed. Practical Handbook of Ground-Water Monitoring, Chelsea, Lewis Publishers, 1991. chap. 4, p.97-141.

BEAR, J. Dynamics of Fluids in Porous Media. New York, American Elsevier Publishing Co., 1966. $764 \mathrm{p}$.

BROWN, K. W. Monitoring the unsaturated zone. In: WATER RESOURCES SYMPOSIUM, 30., Austin, 1986. Land treatment - A Hazardous Waste Management Alternative. Austin, LOEHR, R.C. \& MALINA JR., J.F., 1986. p. 171-185.

CAMPOS, H.C.N.S. Caracterização e cartografia das Províncias Hidroquímicas do Estado de São Paulo. São Paulo, 1993. 177p. (Doutorado - Instituto de Geociências da USP)

CASARINI, D.C.P. Efeito da fertirrigação com vinhaça nas propriedades químicas e microbiológicas do solo em um sistema de disposição de efluente industrial. São Carlos, 1989. 180p. (Doutorado - Escola de Engenharia de São Carlos - USP)

CLEARY, R.W. Águas subterrâneas. In: Engenharia Hidrológica - Coleção ABRH (Associação Brasileira de Recursos Hídricos) de Recursos Hídricos. Rio de Janeiro, Editora da UFRJ, 1989. Vol. 2, cap. 5, p. 292-404.

CLEARY, R.W. Qualidade da água subterrânea. In: Hidrologia Ambiental - Coleção ABRH (Associação Brasileira de Recursos Hídricos)de Recursos Hídricos. São Paulo, Editora da USP, 1991. Vol. 3, parte 2, cap. 3, p. 211-266.1991)

COPERSUCAR Coletânea de anúncios sobre álcool e açúcar. 1989, 56p.

COSTA, C.A.S. Mineralização de enxofre orgânico e adsorção de sulfatos em solos. Porto Alegre, 1980. 65p. (Mestrado - Faculdade de Agronomia da UFRGS). 
CREASEY, C. L. \& DREISS, S. J. Soil water samplers: do they significanty bias concentrations in water samples? In: NWWA (NATIONAL WATER WELL ASSOCIATION) CONFERENCE ON CHARACTERIZATION AND MONITORING OF THE VADOSE ZONE, Denver, 1985. Proceedings. Dublin, National Water Well Association, 1985. p. 173181.

CRUZ, R.L.; RIGHETTO, A.M.; NOGUEIRA, M.A. Experimental investigation of soil and groundwater impacts caused by vinasse disposal. In: INTERNATIONAL SEMINAR OF POLLUTION, PROTECTION AND CONTROL OF GROUNDWATER. Porto Alegre, 1990. Anais. Porto Alegre, Associação Brasileira de Águas Subterrâneas (ABAS), Associação Brasileira de Engenharia Sanitária e Ambiental (ABES), International Association on Water Pollution Research and Control (IAWPRC), 1990. p. 66-74.

CULLEN, S.; KRAMER, J.; EVERETT, L.; ECCLES, L. Is our ground water monitoring strategy illogical? Ground Water Monitoring Review, Dublin, 12 (3): 103-107, summer 1992.

CUNHA, R.C.A.; COSTA, A.C.S.; MASET FILHO, B; CASARINI, D.C.P. Effects of irrigation with vinasse and the dynamics of its constituentes in the soil: I - physical and chemical aspects. Water Science and Technology, London, 19:155-165, 1987.

DAEE (Departamento de águas e Energia Elétrica). Estudo de Águas Subterrâneas, Região Administrativa 6 - Ribeirão Preto (SP). São Paulo, GEOPESQUISADORA/TAHAL, 1974. Vol. 1, 75p.

DAEE (Departamento de águas e Energia Elétrica) \& UNESP (Universidade Estadual de São Paulo) Mapa Geológico do Estado de São Paulo. Esc. 1:250.000, Folha Ribeirão Preto.

DALTON, M.G.; HUNTSMAN, B.E.; BRADBURY, K. Acquisition and interpretation of waterlevel data. In: NIELSEN, M.N., ed. Practical Handbook of Ground-Water Monitoring, Chelsea, Lewis Publishers, 1991. chap. 9, p. 367-395.

DAVIDSON, J.M.; RAO, P.S.C.; NKEDI-KIZZA, P. Physical processes influencing water and solute transport in soils. In: SOIL SCIENCE SOCIETY OF AMERICA. Chemical Mobility and Reactivity in Soil Systems. Madison, American Society of Agronomy (ASA), 1983. Special publication, number 11 , chap. 3 , p. 35-45. 
DAVINO, A; SINELLI, O; CORREA, C.T. Diabásios na região nordeste da Bacia do Paraná. In: CONGRESSO BRASILEIRO DE GEOLOGIA, 32. Salvador, 1982. Anais. Salvádor, SOCIEDADE BRASILEIRA DE GEOLOGIA (SBG), 1982. p. 1736-1744.

DRISCOLL, F.G. Groundwater and wells. St. Paul, Johnson Division, 1986. 1108p.

DURANT, N.D.; MYERS, V.B. and ECCLES, L.A. EPA's approach to vadose zone monitoring at RCRA facilities. Ground Water Monitoring and Remediation, Dublin, 13: 151-158, winter, 1993.

FETTER, C.W. JR. Applied Hydrogeology. Columbus, Charles E. Merrill Publishing Co., 1988. 592p.

FETTER, C.W. JR. Contaminant Hydrogeology. New York, Macmillan Publishing Co.,1993. $458 \mathrm{p}$.

FREEZE, R. A. \& CHERRY Groundwater. Englewood Cliffs, Prentice Hall, 1979. 604p.

GLOEDEN, E.; CUNHA, R.C.A.; FRACCAROLI, M.J.B.; CLEARY, R.W. The behavior of vinasse constituents in the unsaturated and saturated zones in the Botucatu Aquifer Recharge Area. Water Science Technology, London, 24 (11): 147-157, 1991.

GROVER, B. L. \& LAMBORN, R. E. Preparation of porous ceramic cups to be used for extraction of soil water having low solute concentrations. Soil Science Society of America Proceedings, Madison, 34: 706-708, 1970.

HAINES, B. L.; WAIDE, J. B. and TODD, R.L. Soil solution nutrient concentration sampled with tension and zero tension lysimeters: report of discrepancies. Soil Science Society of America Journal, Madison, 46: 658-661, 1982.

HANSEN, E. A. \& HARRIS, A. R. Validity of soil water samples collected with porous ceramic cups. Soil Science Society of America Proceedings, Madison, 39: 528-536, 1975.

HASSUDA, S. Impactos da infiltração da vinhaça de cana no Aquífero Bauru. São Paulo, 1989. 92 p. (Mestrado - Instituto de Geociências da USP) 
HASSUDA, S.; REBOUÇAS, A.C. e CUNHA, R.C.A Aspectos qualitativos da infiltração da vinhaça de cana no Aquífero Bauru. Revista do Instituto Geológico, São Paulo, 11 (2): 5 20, jul./dez. 1990.

HASSUDA, S.; MENDES, J.M.B.; REBOUÇAS, A.C.; CUNHA R.C.A.; GLOEDEN, E. Influência dos vários tipos de disposição de vinhaça na qualidade da água subterrânea. In: ENCONTRO NACIONAL DE ESTUDOS SOBRE O MEIO AMBIENTE, 3., Londrina, 1992. Anais. Londrina, 1992. p. 510 - 515.

HESPANHOL, I. Efeitos ambientais do Programa Nacional do Álcool. In: CONGRESSO BRASILEIRO DE ENGENHARIA SANITÁRIA E AMBIENTAL, 10., Manaus, 1979. Anais. Manaus, 1979. vol. 22, 41p.

HILLEL, D. Fundamentals of Soil Physics. New York, Academic Press, 1980a. 413p.

HILLEL, D. Applications of Soil Physics. New York, Academic Press, 1980b. 383p.

HORNBY, W. J.; ZABICK, J. D.; CRAWLEY, W. Factors which affect soil pore liquid: a comparation of currenthy avaliable samplers with two new desings. Ground Water Monitoring, Dublin, 61-66, spring, 1986.

IBGE (Instituto Brasileiro de Geografia e Estatística) Mapa Topográfico. Esc. 1:50.000, Folha de Serrana.

UNIVERSIDADE DE WATERLOO \& UNIVERSIDADE DE SÃO PAULO RESIST P, Programa para interpretação de sondagens elétricas, 1986.

KIMMELMANN, A.A.; REBOUÇAS, A.C.; SOUZA, J.C.S.; REBOUÇAS, A.M.; BASTOS, F.W.; HEINE, C.A. Considerações sobre as anomalias de fluoreto no Sistema Aqüúfero Botucatu-Pirambóia, na Bacia do Paraná. In: CONGRESSO BRASILEIRO DE ÁGUAS SUBTERRÂNEAS, 6. Porto Alegre, 1990. Anais. Porto Alegre, ASSOCIAÇÃo BRASILEIRA DE ÁGUAS SUBTERRÂNEAS (ABAS), 1990. p.107-111.

LEVIN, M. J. \& JACKSON, D. R. A comparison of in situ extractors for sampling soil water. Soil Science Society of America Journal, Madison, 41: 535-536, 1977.

LEYR, J.H. . The misunderstood word of unsaturated flow. Ground Water Monitoring Review, Dublin, 4-6, spring, 1988. 
LITAOR, M. I. Review of soil solution samplers. Water Kesources Research, 24 (5): 727-733, 1988.

NELSON, A. B. Use of vacuum tanks with shallow vacuum lysimeters Ground Water, Dublin, 23 (6): 802-803, nov./ dec., 1985.

PARIZEK, R.R. \& LANE, B. E. Soil water sampling using pan and deep pressure-vacuum lysimeters. Journal of Hydrology, 11: 1-21, 1970.

PETERS, A. C. \& HEALY, W. R. The representativeness of pore water samples collected from the unsatureted zone using pressure-vacuum lysimeter. Ground Water Monitoring Review, Dublin, 96-101, spring, 1988.

REICHARDT, K. Processos de tranferência no sistema solo-planta-atmosfera. 4a. ed. Campinas, Fundação Cargill, 1985. 445 p.

ROCHA, G.A.(1986). Riscos de poluição das águas subterrâneas no Estado de São Paulo. In: REUNIÃO DO COMITÊ DO PROGRAMA DE PREVENÇÃO E CONTROLE DE CONTAMINAÇÃO DAS ÁGUAS SUBTERRÂNEAS, 2., Cidade do México, 1986. Informe. Cidade do México, Centro Panamericano de Engenharia Sanitária e Ciências do Meio Ambiente (CEPIS), 1986. 30p.

SARA, M.N. (1991). Groud-Water Monitoring System Design. In: NIELSEN, M.N., ed. Practical Handbook of Ground-Water Monitoring, Chelsea, Lewis Publishers, 1991. chap. 2, p. 17-68.

SEVEE, J. Methods and procedures for defining aquifer parameters. In: NIELSEN, M.N., ed. Practical Handbook of Ground-Water Monitoring, Chelsea, Lewis Publishers, 1991. chap. 10 , p. $397-447$.

SINELLI, O. Estudos hidrogeológicos da Bacia do Rio Pardo (SP). Revista Águas Subterrâneas, São Paulo, (11): 5-25, 1987.

SILKWORTH, D. R. \& GRIGAL, D. F. Field comparision of soil solution samplers. Soil Science Society of America Journal, Madison, 45: 446-442, 1981. 
STARR, M. R. Variation in the quality of tension lysimeter soil water samples from a finnish forest. Soil Science, Baltimore, 180: 453-461, 1985.

SZIKSZAY, M. Estação experimental de hidrogeoquímica (Cidade Universitária USP). In: JORNADAS CIENTÍFICAS DO INSTITUTO DE GEOCIÊNCIAS - USP. São Paulo, 1990. Boletim Especial. São Paulo, Instituto de Geociências da USP, 1990. p. 139-142.

TADROS, V. T. \& GARITY, J. W. Mc. A methods for collecting soil percolate and soil solution in the field. Plant soil, 44: 655-667, 1976.

TOOD, D.K. Ground water hydrology. New York, John Wiley \& Sons, 1959. 319p.

USEPA (United States Environmental Protection Agency) Monitoring in the vadose zone: a review of technical elements and methods. Las Vegas, EPA-600/7-80-134, 1980. 168p.

USEPA (United States Environmental Protection Agency) Permit guidance manual on unsaturated zone monitoring for hazardous waste land treatment units. Washington DC, EPA/530 - SW-84-016, 1984. 99p.

USEPA (United States Environmental Protection Agency) Permit guidance manual on unsaturated zone monitoring for hazardous wastes land treatment units.Las Vegas, EPA/530-SW-86-040, 1986a.111 p.

USEPA (United States Environmental Protection Agency) RCRA Ground water monitoring technical enforcement guidance document. 1986b. 208p.

USEPA (United States Environmental Protection Agency) Handbook - Ground Water. Ada, EPA/625/6-87/016, 1987. 212p.

U.S. SALINITY LABORATORY RETC.F77 - Program to analyse observed soil water retention and hydraulic conductivity data. 1987.

VAN DER PLOEG, R. R. \& BEESE, F. Model calculations for the extraction of soil water by ceramic cups and plates. Soil Science Society of America Journal, Madison, 41: 466-470, 1977.

VAN GENUCHTEN, M.T. A closed-form equation for predicting the hidraulic conductivity of unsaturated soil. Soil Science Society of America Journal, Madison, 44 : 892-898, 1980. 
WAGNER, G. H. Use of porous ceramic cups to sample soil water withim profile. Soil Science, Baltimore, 94: 379-386, 1962.

WILSON, L. G. Monitoring in the vadose zone, part 1: storage changes. Ground Water Monitoring Review, Dublin, 1 (3): 32-41, 1981.

WILSON, L.G. Monitoring in the vadose zone, Part 2. Ground Water Monitoring Review, Dublin, 2 (1): 31-42, 1982.

WILSON, L.G. Monitoring in the vadose zone, Part 3. Ground Water Monitoring Review, Dublin, Winter, p. 155-166, 1983.

WOOD, W. W. A technique using porous cups for water sampling at any deph in the unsaturated zone. Water Resources Research, 9 (2): 486-488, 1973. 
Tabela 1 - Resultados dos cálculos de fluxo de água (03/05/89 a 29/07/89)

\begin{tabular}{|c|c|c|c|c|c|c|c|c|c|c|}
\hline DATA & DIA & AREA & $\begin{array}{c}\mathrm{PROF} \\
\mathrm{cm}\end{array}$ & $\begin{array}{c}\text { POT. HIDR } \\
\mathrm{cm}\end{array}$ & $\begin{array}{c}\text { POT. MAT } \\
\mathrm{cm}\end{array}$ & $\mid \begin{array}{c}\theta \\
\mathrm{cm}^{3} / \mathrm{cm}^{3}\end{array}$ & $\begin{array}{c}\mathrm{K}(\theta) \\
\mathrm{cm} / \mathrm{dia}\end{array}$ & CAMADA & $\begin{array}{c}q \\
\mathrm{~cm} / \mathrm{dia}\end{array}$ & $\begin{array}{c}\mathbf{v} \\
\mathrm{cm} / \mathrm{dia}\end{array}$ \\
\hline $03 / 05 / 89$ & 3 & 1 & 20 & $-82,40$ & $-62,40$ & $1,61 \mathrm{E}-01$ & $1,35 \mathrm{E}-01$ & & & \\
\hline $03 / 05 / 89$ & 3 & 1 & 60 & $-194,80$ & $-134,80$ & $6,63 \mathrm{E}-02$ & $2,40 \mathrm{E}-03$ & $20-60$ & $6.74 E-03$ & $1,02 \mathrm{E}-01$ \\
\hline $03 / 05 / 89$ & 3 & 1 & 100 & $-209,33$ & $-109,33$ & $7,81 \mathrm{E}-02$ & $4,08 \mathrm{E}-03$ & $60-100$ & $1,48 \mathrm{E}-03$ & $1,89 \mathrm{E}-02$ \\
\hline $03 / 05 / 89$ & 3 & 1 & 140 & $-209,33$ & $-69,33$ & $1,58 \mathrm{E}-0 \mathrm{t}$ & $9,93 \mathrm{E}-02$ & $100-140$ & $0,00 \mathrm{E}+00$ & $0,00 \mathrm{E}+00$ \\
\hline $03 / 05 / 89$ & 3 & 1 & 180 & $-207,23$ & $-27,23$ & $3,30 \mathrm{E}-01$ & $4,83 \mathrm{E}+00$ & $140-180$ & $-2,54 \mathrm{E}-01$ & $-7,70 \mathrm{E}-01$ \\
\hline $03 / 05 / 89$ & 3 & 1 & 220 & $-213,45$ & 6.55 & $4,00 \mathrm{E}-0 \mathrm{I}$ & $1,46 \mathrm{E}+01$ & $180-220$ & $2,27 \mathrm{E}+00$ & $5,69 \mathrm{E}+00$ \\
\hline $05 / 05 / 89$ & 5 & 1 & 20 & $-116,93$ & $-96,93$ & $1,05 \mathrm{E}-01$ & $1,52 \mathrm{E}-02$ & & & \\
\hline $05 / 05 / 89$ & 5 & 1 & 60 & $-229,20$ & $-169,20$ & $5,45 \mathrm{E}-02$ & $6,40 \mathrm{E}-04$ & $20-60$ & $1,80 \mathrm{E}-03$ & $3,29 \mathrm{E}-02$ \\
\hline $05 / 05 / 89$ & 5 & 1 & 100 & $-194,63$ & $-94,63$ & $8,91 \mathrm{E}-02$ & $9,18 \mathrm{E}-03$ & $60-100$ & $-7,93 \mathrm{E}-03$ & $-8,90 \mathrm{E}-02$ \\
\hline $05 / 05 / 89$ & 5 & 1 & 140 & $-188,33$ & $-48,33$ & $2,12 \mathrm{E}-01$ & $4,73 \mathrm{E}-01$ & $100-140$ & $-7,45 \mathrm{E}-02$ & $-3,51 \mathrm{E}-01$ \\
\hline $05 / 05 / 89$ & 5 & 1 & 180 & $-207,15$ & $-27,15$ & $3,30 \mathrm{E}-01$ & $4,86 \mathrm{E}+00$ & $140-180$ & $2,29 \mathrm{E}+00$ & $6,93 \mathrm{E}+00$ \\
\hline $05 / 05 / 89$ & 5 & 1 & 220 & $-197,70$ & 22,30 & $3,27 \mathrm{E}-0 \mathrm{I}$ & $3,38 \mathrm{E}+00$ & $180-220$ & $-7,99 \mathrm{E}-01$ & $-2,44 \mathrm{E}+00$ \\
\hline $08 / 05 / 89$ & 8 & 1 & 20 & $-90,60$ & $-70,60$ & $1,43 \mathrm{E}-01$ & $7,50 \mathrm{E}-02$ & & & \\
\hline $08 / 05 / 89$ & 8 & 1 & 60 & $-150,70$ & $.90,70$ & $9,84 \mathrm{E}-02$ & $2,28 \mathrm{E}-02$ & $20-60$ & $3,42 \mathrm{E}-02$ & $3,48 \mathrm{E}-01$ \\
\hline $08 / 05 / 89$ & 8 & 1 & 100 & $-184,13$ & $-84,13$ & $9,96 \mathrm{E}-02$ & $1,76 \mathrm{E}-02$ & $60-100$ & $1,47 \mathrm{E}-02$ & $1,48 \mathrm{E}-01$ \\
\hline $08 / 05 / 89$ & 8 & 1 & 140 & $-186,23$ & $-46,23$ & $2,20 \mathrm{E}-01$ & $5,64 \mathrm{E}-01$ & $100-140$ & $2,96 \mathrm{E}-02$ & $1,35 \mathrm{E}-01$ \\
\hline $08 / 05 / 89$ & 8 & 1 & 180 & $-186,23$ & $-6,23$ & $3,80 \mathrm{E}-01$ & $1,67 \mathrm{E}+01$ & $140-180$ & $0,00 \mathrm{E}+00$ & $0,00 \mathrm{E}+00$ \\
\hline $08 / 05 / 89$ & 8 & 1 & 220 & $-194,55$ & 25,45 & $3,10 \mathrm{E}-01$ & $2,46 \mathrm{E}+00$ & $180-220$ & $5,12 \mathrm{E}-01$ & $1,65 \mathrm{E}+00$ \\
\hline $10 / 05 / 89$ & 10 & 1 & 20 & $-84,30$ & $-64,30$ & $1,57 \mathrm{E}-01$ & $1,17 \mathrm{E}-01$ & & & \\
\hline $10 / 05 / 89$ & 10 & 1 & 60 & $-149,95$ & $-89,95$ & $9,93 \mathrm{E}-02$ & $2,39 \mathrm{E}-02$ & $20-60$ & $3,92 \mathrm{E}-02$ & $3,94 \mathrm{E}-01$ \\
\hline $10 / 05 / 89$ & 10 & 1 & 100 & $-179,93$ & $-79,93$ & $1,05 \mathrm{E}-01$ & $2,33 \mathrm{E}-02$ & $60-100$ & $1,75 \mathrm{E}-02$ & $1,67 \mathrm{E}-01$ \\
\hline $10 / 05 / 89$ & 10 & 1 & 140 & $-186,23$ & $-46,23$ & $2,20 \mathrm{E}-01$ & $5,64 \mathrm{E}-01$ & $100-140$ & $8,88 \mathrm{E}-02$ & $4,04 \mathrm{E}-01$ \\
\hline $10 / 05 / 89$ & 10 & 1 & 180 & $-190,43$ & $-10,43$ & $3,74 \mathrm{E}-01$ & $1,35 \mathrm{E}+01$ & $140-180$ & $1,42 \mathrm{E}+00$ & $3,79 \mathrm{E}+00$ \\
\hline $10 / 05 / 89$ & 10 & 1 & 220 & $-197,70$ & 22,30 & $3,27 \mathrm{E}-01$ & $3,38 \mathrm{E}+00$ & $180-220$ & $6,15 \mathrm{E}-01$ & $1,88 \mathrm{E}+00$ \\
\hline $12 / 05 / 89$ & 12 & 1 & 20 & $-100,05$ & $-79,90$ & $1,27 \mathrm{E}-01$ & $4,07 \mathrm{E}-02$ & & & \\
\hline $12 / 05 / 89$ & 12 & 1 & 60 & $-153,10$ & $-93,10$ & $9,57 \mathrm{E}-02$ & $1,97 \mathrm{E}-02$ & $20-60$ & $2,61 \mathrm{E}-02$ & $2,73 \mathrm{E}-01$ \\
\hline $12 / 05 / 89$ & 12 & 1 & 100 & $-186,23$ & $-86,23$ & $9,73 \mathrm{E}-02$ & \begin{tabular}{|l|}
$1,54 \mathrm{E}-02$ \\
\end{tabular} & $60-100$ & $1,27 \mathrm{E}-02$ & $1,31 \mathrm{E}-01$ \\
\hline $12 / 05 / 89$ & 12 & 1 & 140 & $-188,33$ & $-48,33$ & $2,12 \mathrm{E}-01$ & $4,73 \mathrm{E}-01$ & $100-140$ & $2,48 \mathrm{E}-02$ & $1,17 \mathrm{E}-01$ \\
\hline $12 / 05 / 89$ & 12 & 1 & 180 & $-196,73$ & $-16,73$ & $3,60 \mathrm{E}-01$ & $9,40 \mathrm{E}+00$ & $140-180$ & $1,97 \mathrm{E}+00$ & $5,48 \mathrm{E}+00$ \\
\hline $12 / 05 / 89$ & 12 & 1 & 220 & $-204,00$ & 16,00 & $3,61 \mathrm{E}-01$ & $6,34 \mathrm{E}+00$ & $180-220$ & $1,15 E+00$ & $3,19 \mathrm{E}+00$ \\
\hline $15 / 05 / 89$ & 15 & 1 & 20 & $-103,20$ & $-83,20$ & $1,22 \mathrm{E}-01$ & $3,32 \mathrm{E}-02$ & & & \\
\hline $15 / 05 / 89$ & 15 & 1 & 60 & $-168,85$ & $-108,85$ & $8,15 \mathrm{E}-02$ & $8,18 \mathrm{E}-03$ & $20-60$ & $1,34 \mathrm{E}-02$ & $1,65 \mathrm{E}-01$ \\
\hline $15 / 05 / 89$ & 15 & 1 & 100 & $-184,13$ & $-84,13$ & $9,96 \mathrm{E}-02$ & $1,76 \mathrm{E}-02$ & 60.100 & $6,72 \mathrm{E}-03$ & $6,75 \mathrm{E}-02$ \\
\hline $15 / 05 / 89$ & 15 & 1 & 140 & $-188,33$ & $-48,33$ & $2,12 \mathrm{E}-01$ & $4,73 \mathrm{E}-01$ & $100-140$ & $4,97 \mathrm{E}-02$ & $2,34 \mathrm{E}-01$ \\
\hline $15 / 05 / 89$ & 15 & 1 & 180 & $-196,73$ & $-16,73$ & $3,60 \mathrm{E}-01$ & $9,40 \mathrm{E}+00$ & $140-180$ & $1,97 \mathrm{E}+00$ & $5,48 \mathrm{E}+00$ \\
\hline $15 / 05 / 89$ & 15 & 1 & 220 & $-204,00$ & 16,00 & $3,61 \mathrm{E}-01$ & $6,34 \mathrm{E}+00$ & $180-220$ & $1,15 \mathrm{E}+00$ & $3,19 \mathrm{E}+00$ \\
\hline $17 / 05 / 89$ & 17 & 1 & 20 & $-122,10$ & $-102,10$ & $1,00 \mathrm{E}-01$ & $1,16 \mathrm{E}-02$ & & & \\
\hline $17 / 05 / 89$ & 17 & 1 & 60 & $-175,15$ & $-115,15$ & $7,70 \mathrm{E}-02$ & $5,94 \mathrm{E}-03$ & $20-60$ & $7,87 \mathrm{E}-03$ & $1,02 \mathrm{E}-01$ \\
\hline $17 / 05 / 89$ & 17 & 1 & 100 & $-192,53$ & $-92,53$ & $9,10 \mathrm{E}-02$ & $1,04 \mathrm{E}-02$ & $60-100$ & $4,52 \mathrm{E}-03$ & $4,97 \mathrm{E}-02$ \\
\hline $17 / 05 / 89$ & 17 & 1 & 140 & $-194,63$ & $-54,63$ & $1,93 \mathrm{E}-01$ & $2,85 \mathrm{E}-01$ & $100-140$ & $1,50 \mathrm{E}-02$ & $7,78 \mathrm{E}-02$ \\
\hline $17 / 05 / 89$ & 17 & 1 & 180 & $-200,93$ & $-20,93$ & $3,49 \mathrm{E}-01$ & $7,25 \mathrm{E}+00$ & $140-180$ & $1,14 \mathrm{E}+00$ & $3,27 \mathrm{E}+00$ \\
\hline $17 / 05 / 89$ & 17 & 1 & 220 & $-213,45$ & 6.55 & $4,00 \mathrm{E}-01$ & $1,46 \mathrm{E}+01$ & $180-220$ & $4,57 \mathrm{E}+00$ & $1,14 \mathrm{E}+01$ \\
\hline $19 / 05 / 89$ & 19 & 1 & 20 & $-134,70$ & $-114,70$ & $8,96 \mathrm{E}-02$ & $6,34 \mathrm{E}-03$ & & & \\
\hline $19 / 05 / 89$ & 19 & 1 & 60 & $.175,15$ & $-115,15$ & $7,70 \mathrm{E}-02$ & 5,94E-03 & $20-60$ & $6,00 \mathrm{E}-03$ & $7,79 \mathrm{E}-02$ \\
\hline $19 / 05 / 89$ & 19 & 1 & 100 & $-184,13$ & $-84,13$ & $9,96 \mathrm{E}-02$ & $1,76 \mathrm{E}-02$ & $60-100$ & $3,95 \mathrm{E}-03$ & $3,97 \mathrm{E}-02$ \\
\hline $19 / 05 / 89$ & 19 & 1 & 140 & $-198,83$ & $-58,83$ & \begin{tabular}{|l|}
$1,81 \mathrm{E}-01$ \\
\end{tabular} & $2,08 \mathrm{E}-01$ & $100-140$ & $7,63 \mathrm{E}-02$ & $4,21 \mathrm{E}-01$ \\
\hline $19 / 05 / 89$ & 19 & 1 & 180 & $-205,13$ & $-25,13$ & $3,36 \mathrm{E}-01$ & $5,54 \mathrm{E}+00$ & $140-180$ & $8,73 \mathrm{E}-01$ & $2,60 \mathrm{E}+00$ \\
\hline $19 / 05 / 89$ & 19 & 1 & 220 & $-214,70$ & 5,30 & $4,03 \mathrm{E}-01$ & $1,60 \mathrm{E}+01$ & $180-220$ & $3,83 \mathrm{E}+00$ & $9,52 \mathrm{E}+00$ \\
\hline $22 / 05 / 89$ & 22 & 1 & 20 & $-134,70$ & $-114,70$ & $8,96 \mathrm{E} \sim 02$ & $6,34 \mathrm{E}-03$ & & & \\
\hline $22 / 05 / 89$ & 22 & 1 & 60 & $-219,25$ & $-159,25$ & $5,73 \mathrm{E}-02$ & $9,11 \mathrm{E}-04$ & $20-60$ & $1,93 \mathrm{E}-03$ & $3,36 \mathrm{E}-02$ \\
\hline $22 / 05 / 89$ & 22 & 1 & 100 & $-192,53$ & $-92,53$ & $9,10 \mathrm{E}-02$ & $1,04 \mathrm{E}-02$ & $60-100$ & $-6,95 \mathrm{E}-03$ & $-7,64 \mathrm{E}-02$ \\
\hline $22 / 05 / 89$ & 22 & 1 & 140 & $-194,63$ & $-54,63$ & $1,93 \mathrm{E}-01$ & $2,85 \mathrm{E}-01$ & $100-140$ & $1,50 \mathrm{E}-02$ & $7,78 \mathrm{E}-02$ \\
\hline $22 / 05 / 89$ & 22 & 1 & 180 & $-200,85$ & $-20,85$ & $3,49 \mathrm{E}-01$ & $7,29 \mathrm{E}+00$ & $140-180$ & $1,13 \mathrm{E}+00$ & $3,24 \mathrm{E}+00$ \\
\hline $22 / 05 / 89$ & 22 & 1 & 220 & $-207,15$ & 12,85 & $3,77 \mathrm{E}-01$ & $8,56 \mathrm{E}+00$ & $180-220$ & $1,35 \mathrm{E}+00$ & $3,58 \mathrm{E}+00$ \\
\hline $24 / 05 / 89$ & 24 & 1 & 20 & $-153,60$ & $-133,60$ & $7,80 \mathrm{E}-02$ & $2,83 \mathrm{E}-03$ & & & \\
\hline $24 / 05 / 89$ & 24 & 1 & 60 & $-231,85$ & $-171,85$ & $5,39 \mathrm{E}-02$ & $5,84 \mathrm{E}-04$ & $20-60$ & $1,14 \mathrm{E}-03$ & $2,12 \mathrm{E}-02$ \\
\hline $24 / 05 / 89$ & 24 & 1 & 100 & $-205,13$ & $-105,13$ & $8,09 \mathrm{E}-02$ & $5,09 \mathrm{E}-03$ & $60-100$ & $-3,40 \mathrm{E}-03$ & $-4,20 \mathrm{E}-02$ \\
\hline $24 / 05 / 89$ & 24 & 1 & 140 & $-196,73$ & $-56,73$ & $1,87 \mathrm{E}-01$ & $2,43 \mathrm{E}-0 \mathrm{~J}$ & $100-140$ & $-5,10 \mathrm{E}-02$ & $-2,73 \mathrm{E}-01$ \\
\hline $24 / 05 / 89$ & 24 & 1 & 180 & $-209,33$ & $-29,33$ & $3,23 \mathrm{E}-01$ & $4,21 \mathrm{E}+00$ & $140-180$ & $1,33 \mathrm{E}+00$ & $4,11 \mathrm{E}+00$ \\
\hline $24 / 05 / 89$ & 24 & 1 & 220 & $-219,75$ & 0,25 & $4,08 \mathrm{E}-01$ & $2,16 \mathrm{E}+0 \mathrm{1}$ & $180-220$ & $5,61 \mathrm{E}+00$ & $1,38 E+01$ \\
\hline
\end{tabular}


Tabela 1 (continuação)

\begin{tabular}{|c|c|c|c|c|c|c|c|c|c|c|}
\hline DATA & DIA & ÁREA & $\begin{array}{c}\text { PROF } \\
\mathrm{cm}\end{array}$ & $\begin{array}{c}\text { POT. HIDR } \\
\mathrm{cm}\end{array}$ & $\begin{array}{c}\text { POT. MAT } \\
\mathrm{cm}\end{array}$ & $\begin{array}{c}\theta \\
\mathrm{cm}^{3} / \mathrm{cm}^{3}\end{array}$ & $\begin{array}{c}\mathrm{K}(\theta) \\
\mathrm{cm} / \mathrm{dia}\end{array}$ & CAMADA & $\begin{array}{c}q \\
\mathrm{~cm} / \mathrm{dia}\end{array}$ & $\begin{array}{c}v \\
\mathrm{~cm} / \mathrm{dia}\end{array}$ \\
\hline $26 / 05 / 89$ & 26 & 1 & 20 & $-200,85$ & $-180,85$ & $6,08 \mathrm{E}-02$ & $5,59 \mathrm{E}-04$ & & & \\
\hline $26 / 05 / 89$ & 26 & 1 & 60 & $-232,60$ & $-172,60$ & $5,37 \mathrm{E}-02$ & $5,70 \mathrm{E}-04$ & & $4,52 \mathrm{E}-04$ & $8,42 \mathrm{E}-03$ \\
\hline $26 / 05 / 89$ & 26 & 1 & 100 & $-217,73$ & $-117,73$ & $7,33 \mathrm{E}-02$ & $2,68 \mathrm{E}-03$ & & $-9,96 \mathrm{E}-04$ & $-1,36 \mathrm{E}-02$ \\
\hline $26 / 05 / 89$ & 26 & -1 & 140 & $-203,03$ & & $1,71 \mathrm{E}-01$ & $1,53 \mathrm{E}-01$ & & $-5,62 \mathrm{E}-02$ & \\
\hline & 26 & 1 & 180 & & & $3,09 \mathrm{E}-01$ & $3,20 \mathrm{E}+00$ & & $8,40 \mathrm{E}-01$ & $2,72 \mathrm{E}+00$ \\
\hline $26 / 05 / 89$ & 26 & 1 & 220 & & & $4,06 \mathrm{E}-01$ & $1,88 \mathrm{E}+01$ & & $4,40 \mathrm{E}+00$ & $1,08 \mathrm{E}+01$ \\
\hline $29 / 05 / 89$ & 29 & 1 & 20 & $-200,85$ & $-180,85$ & $6.08 \mathrm{E}-02$ & $5,59 \mathrm{E}-04$ & & & \\
\hline $29 / 05 / 89$ & 29 & 1 & 60 & $-220,00$ & & $5,71 \mathrm{E}-02$ & $8,87 \mathrm{E}-04$ & & $4,25 \mathrm{E}-04$ & $7,44 \mathrm{E}-03$ \\
\hline & 29 & 1 & 100 & & & $7,56 \mathrm{E}-02$ & $3,29 \mathrm{E}-03$ & & & $-7,04 \mathrm{E}-03$ \\
\hline & 29 & 1 & 140 & & & $1,76 \mathrm{E}-01$ & $1,78 \mathrm{E}-01$ & & & \\
\hline & 29 & 1 & 180 & & & $3,16 \mathrm{E}-01$ & $3,67 \mathrm{E}+00$ & & & $E+\infty$ \\
\hline $29 / 05 / 89$ & 29 & 1 & 220 & & & $4,08 \mathrm{E}-01$ & $2,16 E+01$ & & & $E+01$ \\
\hline $31 / 05 / 89$ & 31 & 1 & 20 & & & $6,00 \mathrm{E}-02$ & $5,10 \mathrm{E}-04$ & & & \\
\hline & 31 & 1 & 6 & & & & $1,12 \mathrm{E}-03$ & & $2,72 E-04$ & $4,60 \mathrm{E}-03$ \\
\hline & 31 & 1 & 100 & & & $E-02$ & $2,97 \mathrm{E}-03$ & & & \\
\hline & 31 & 1 & 140 & & & & & & & -01 \\
\hline & 31 & 1 & 180 & & & & $2,79 \mathrm{E}+00$ & & $E+00$ & $E+00$ \\
\hline & 31 & 1 & 220 & & & E-01 & $2,16 \mathrm{E}+01$ & & $2 \mathrm{E}+00$ & $\mathrm{E}+00$ \\
\hline & 33 & 1 & 20 & & & & $5,59 \mathrm{E}-04$ & & & \\
\hline & 33 & 1 & & & & & $7,08 \mathrm{E}-04$ & & & \\
\hline & 33 & 1 & & & & & & & & \\
\hline & 33 & 1 & & & & & $3 \mathrm{E}-01$ & & & $\mathrm{E}-01$ \\
\hline & 33 & 1 & & & & & $3,20 \mathrm{E}+00$ & & +00 & $E+00$ \\
\hline & 33 & 1 & & & & & $1,52 \mathrm{E}+01$ & & & $\mathrm{E}+01$ \\
\hline & 36 & 1 & & & & & E-04 & & & \\
\hline & 36 & 1 & & & & & & & & $\mathrm{E}-03$ \\
\hline & 36 & 1 & & & & & & & & \\
\hline & 36 & 1 & & & & & & & & E-02 \\
\hline & 36 & 1 & & & & & $2,79 \mathrm{E}+00$ & & & $+\infty$ \\
\hline & 36 & 1 & & & & & $\mathrm{E}+01$ & & & $+\infty$ \\
\hline & 38 & 1 & & & & & & & & \\
\hline & 38 & 1 & & & & & & & & \\
\hline & 38 & 1 & & & & & & & & -03 \\
\hline & 38 & 1 & & & & & & & & $E-01$ \\
\hline & 38 & 1 & & & & & $1,85 \mathrm{E}+00$ & & & $8+\infty$ \\
\hline & 38 & 1 & & & & $2-01$ & $1,18 \mathrm{E}+01$ & & & $+\infty$ \\
\hline & 40 & 1 & & & & & & & & \\
\hline & 40 & 1 & 60 & & & & & & & \\
\hline & 40 & 1 & & & & & & & & -02 \\
\hline & 40 & 1 & & & & & & & & -02 \\
\hline & 40 & 1 & & & & & $1,62 \mathrm{E}+00$ & & & E-01 \\
\hline & 40 & 1 & & & & & $6,66 \mathrm{E}+00$ & & +00 & +00 \\
\hline & 43 & 1 & & & & & & & & \\
\hline & 43 & 1 & & & & E-02 & & & & \\
\hline $6 / 89$ & 43 & 1 & & & & E-02 & & & & -02 \\
\hline $12 / 06 / 89$ & 43 & 1 & & & & $\mathrm{E}-01$ & $5,95 \mathrm{E}-02$ & & $\mathrm{E}-03$ & E-02 \\
\hline $5 / 89$ & 43 & 1 & & & & & $4,21 \mathrm{E}+00$ & & $E-01$ & $E+\infty$ \\
\hline & 43 & 1 & & & & & $1,18 \mathrm{E}+01$ & & $8+00$ & $\mathrm{E}+01$ \\
\hline & 45 & 1 & & & & $\mathrm{E}-02$ & & & & \\
\hline & 45 & 1 & & & & & & & & \\
\hline $14 / 06 / 89$ & 45 & 1 & 100 & & & $7,33 \mathrm{E}-02$ & $2,68 \mathrm{E}-03$ & & $42 \mathrm{E}-03$ & $3 \mathrm{E}-02$ \\
\hline $14 / 06 / 89$ & 45 & 1 & 140 & & & $1,43 \mathrm{E}-01$ & $5,95 \mathrm{E}-02$ & & $-5,65 \mathrm{E}-04$ & $-3,94 \mathrm{E}-03$ \\
\hline & 45 & 1 & & & & $3,09 \mathrm{E}-01$ & $3,20 \mathrm{E}+00$ & & E-01 & $-9,88 \mathrm{E}-01$ \\
\hline & 45 & 1 & 220 & & & & $1,88 \mathrm{E}+01$ & & $E+00$ & \\
\hline & 47 & 1 & 20 & & & & & & & \\
\hline & 47 & 1 & 60 & & & $5,89 \mathrm{E}-02$ & & & & \\
\hline $16 / 06 / 89$ & 47 & 1 & & & & $6,57 \mathrm{E}-02$ & $1,23 \mathrm{E}-03$ & & & \\
\hline $16 / 06 / 89$ & 47 & 1 & 140 & & & $1,30 \mathrm{E}-01$ & $3,43 \mathrm{E}-02$ & & $-7,02 \mathrm{E}-03$ & $-5,41 \mathrm{E}-02$ \\
\hline $16 / 06 / 89$ & 47 & 1 & 180 & & & $2,76 \mathrm{E}-01$ & $1,62 \mathrm{E}+00$ & $140-180$ & $-1,12 \mathrm{E}-01$ & $-4,07 \mathrm{E}-01$ \\
\hline $16 / 06 / 89$ & 47 & 1 & 220 & $-241,80$ & $-21,80$ & $3,30 \mathrm{E}-01$ & $3,56 \mathrm{E}+00$ & $180-220$ & $1,58 \mathrm{E}+00$ & $4,79 \mathrm{E}+00$ \\
\hline
\end{tabular}


Tabela 1 (continação)

\begin{tabular}{|c|c|c|c|c|c|c|c|c|c|c|}
\hline DATA & DIA & AREA & $\begin{array}{c}\mathrm{PROF} \\
\mathrm{cm}\end{array}$ & $\begin{array}{c}\text { POT. HIDR } \\
\mathrm{cm}\end{array}$ & $\begin{array}{c}\text { POT. MAT } \\
\mathrm{cm}\end{array}$ & $\begin{array}{c}\theta \\
\mathrm{cm}^{\mathrm{3}} / \mathrm{cm}^{3}\end{array}$ & $\begin{array}{c}\mathrm{K}(\theta) \\
\mathrm{cm} / \mathrm{dia} \\
\end{array}$ & CAMADA & $\begin{array}{c}q \\
\mathrm{~cm} / \mathrm{dia}\end{array}$ & $\begin{array}{c}v \\
\mathrm{~cm} / \mathrm{dia}\end{array}$ \\
\hline $19 / 06 / 89$ & 50 & 1 & 20 & $-231,10$ & $-211,10$ & $5,43 \mathrm{E}-02$ & $2,43 \mathrm{E}-04$ & & & \\
\hline $19 / 06 / 89$ & 50 & 1 & 60 & $-220,00$ & $-160,00$ & $5,71 \mathrm{E}-02$ & $8,87 \mathrm{E}-04$ & $20-60$ & $-2,4 \varsigma \mathrm{E}-04$ & $-4,31 \mathrm{E}-03$ \\
\hline $19 / 06 / 89$ & 50 & 1 & 100 & $-224,03$ & $-124,03$ & $7,02 \mathrm{E}-02$ & $1,99 \mathrm{E}-03$ & $60-100$ & $2,01 \mathrm{E}-04$ & $2,86 \mathrm{E}-03$ \\
\hline $19 / 06 / 89$ & 50 & 1 & 140 & $-228,80$ & $.86,80$ & $1,30 \mathrm{E}-01$ & $3,43 \mathrm{E}-02$ & $100-140$ & $4,09 \mathrm{E}-103$ & $3,15 \mathrm{E}-02$ \\
\hline $19 / 06 / 89$ & 50 & 1 & 180 & $-224,03$ & $-44,03$ & $2,76 \mathrm{E}-01$ & $1,62 \mathrm{E}+00$ & $140-180$ & $-1,94 \mathrm{E}-1$ & $-7,02 \mathrm{E}-01$ \\
\hline $19 / 06 / 89$ & 50 & 1 & 220 & $-226,05$ & $-6,05$ & $4,01 \mathrm{E}-01$ & $1,52 \mathrm{E}+01$ & $180-220$ & $7,66 \mathrm{E}-01$ & $1,91 \mathrm{E}+00$ \\
\hline & 52 & 1 & 20 & & & & & & & \\
\hline $21 / 06 / 89$ & 52 & 1 & 60 & & & & & $20-60$ & & \\
\hline $21 / 06 / 89$ & 52 & 1 & 100 & $-182,03$ & $-82,03$ & $1,02 \mathrm{E}-01$ & $2,02 \mathrm{E}-02$ & $60-100$ & $9,20 \mathrm{E}-02$ & $9,01 \mathrm{E}-01$ \\
\hline $21 / 06 / 89$ & 52 & 1 & 140 & $-198,83$ & $-58,83$ & $1,81 \mathrm{E}-01$ & $2,08 \mathrm{E}-01$ & $100-140$ & $8,72 \mathrm{E}-02$ & $4,81 \mathrm{E}-01$ \\
\hline $21 / 06 / 89$ & 52 & 1 & 180 & $-215,63$ & $-35,63$ & $3,02 \mathrm{E}-01$ & $2,79 \mathrm{E}+00$ & $140-180$ & $1,17 \mathrm{E}+\infty$ & $3,87 \mathrm{E}+00$ \\
\hline & 52 & 1 & 220 & $-207,23$ & 12,77 & $3,77 \mathrm{E}-01$ & $8,62 \mathrm{E}+00$ & & $-1,81 \mathrm{E}+00$ & $-4,80 \mathrm{E}+00$ \\
\hline & 54 & 1 & 20 & & & & & & & \\
\hline $23 / 06 / 89$ & 54 & 1 & 60 & $-201,60$ & $-141,60$ & $6,34 \mathrm{E}-02$ & $1,80 \mathrm{E}-03$ & $20-60$ & $9,09 \mathrm{E}-03$ & $1,43 \mathrm{E}-01$ \\
\hline $23 / 06 / 89$ & 54 & 1 & 100 & -219.83 & $-119,83$ & $7,23 \mathrm{E}-02$ & $2,42 \mathrm{E}-03$ & & $1,10 \mathrm{E}-03$ & $\mathrm{E}-02$ \\
\hline $23 / 06 / 89$ & 54 & 1 & 140 & $-214,20$ & $-74,20$ & $1,49 \mathrm{E}-01$ & $7,24 \mathrm{E}-02$ & $100-140$ & $-1,02 \mathrm{E}-02$ & $6 \mathrm{E}-02$ \\
\hline & 54 & 1 & 180 & & & $3,16 \mathrm{E}-01$ & $3,67 \mathrm{E}+00$ & & -01 & E-01 \\
\hline & 54 & 1 & 220 & & & $3,94 \mathrm{E}-01$ & $1,25 \mathrm{E}+01$ & & $2+\infty$ & +00 \\
\hline $26 / 06 / 89$ & 57 & 1 & 20 & $-169,35$ & $-149,35$ & $7,09 \mathrm{E}-02$ & $1,56 \mathrm{E}-03$ & & & \\
\hline $26 / 06 / 89$ & 57 & 1 & 60 & $-226,80$ & $-166,80$ & $5,52 \mathrm{E}-02$ & $6,95 E_{-} 04$ & $20-60$ & $9,99 \mathrm{E}-04$ & $\mathrm{E}-02$ \\
\hline $26 / 06 / 89$ & 57 & 1 & 100 & $-219,83$ & $-119,83$ & $7,23 \mathrm{E}-02$ & $2,42 \mathrm{E}-03$ & $60-$ & $-4,22 \mathrm{E}-04$ & E-03 \\
\hline & 57 & 1 & 140 & $-220,50$ & $-80,50$ & $1,39 \mathrm{E}-01$ & $4,92 \mathrm{E}-02$ & & -04 & -03 \\
\hline & 57 & 1 & 180 & & & $2,89 \mathrm{E}-01$ & $2,12 E+00$ & & -02 & E-01 \\
\hline $26 / 06 / 89$ & 57 & 1 & 220 & 4,03 & $-4,03$ & $4,05 \mathrm{E}-01$ & $1,75 E+01$ & & $E+00$ & +00 \\
\hline $28 / 06 / 89$ & 59 & 1 & 20 &, 35 & $-149,35$ & $7,09 \mathrm{E}-02$ & $1,56 \mathrm{E}-03$ & & & \\
\hline $3 / 06 / 89$ & 59 & 1 & 60 & $-233,10$ & $-171,10$ & $5,40 \mathrm{E}-02$ & $5,99 \mathrm{E}-04$ & $20-60$ & $9,55 \mathrm{E}-04$ & $1,77 \mathrm{E}-02$ \\
\hline $6 / 89$ & 59 & 1 & 100 & $-228,23$ & $-128,23$ & $6,84 \mathrm{E}-02$ & $1,65 \mathrm{E}-03$ & & E-04 & -03 \\
\hline & 59 & 1 & 140 & & 50 & E-01 & $4,92 \mathrm{E}-02$ & & -03 & -02 \\
\hline & 59 & 1 & 180 & &, 83 & $2,89 \mathrm{E}-01$ & $2,12 E+00$ & & $E-02$ & $E-01$ \\
\hline & 59 & 1 & 220 & .03 & $-4,03$ & $4,05 \mathrm{E}-01$ & $1,75 \mathrm{E}+01$ & & $+\infty$ & $2+00$ \\
\hline $6 / 89$ & 61 & 1 & 20 & & $-199,75$ & $5,64 \mathrm{E}-02$ & $3,27 \mathrm{E}-04$ & & & \\
\hline 189 & 61 & 1 & 60 & .70 & $-185,70$ & $5,08 \mathrm{E}-02$ & $3,71 \mathrm{E}-04$ & & -04 & $2-03$ \\
\hline & 61 & 1 & 100 & & 5,03 & $6,22 \mathrm{E}-02$ & $8,13 \mathrm{E}-04$ & & -05 & $E-04$ \\
\hline & 61 & 1 & 140 & & & $\mathrm{E}-01$ & $3,43 \mathrm{E}-02$ & 1 & $E-02$ & $E-01$ \\
\hline & 61 & 1 & 180 & & & $3,02 \mathrm{E}-01$ & $2.79 \mathrm{E}+00$ & 140 & $\mathrm{E}-01$ & $8 \mathrm{E}+00$ \\
\hline & 61 & 1 & 220 & & & $4,05 \mathrm{E}-01$ & $1,75 \mathrm{E}+01$ & & & $9,07 \mathrm{E}+00$ \\
\hline $107 / 89$ & 63 & 1 & 20 & & & & & & & \\
\hline $2 / 07 / 89$ & 63 & 1 & 60 & & & & & & & \\
\hline & 63 & 1 & 100 & & & & $3,23 \mathrm{E}-04$ & & & -02 \\
\hline & 63 & 1 & 140 & & & $1,10 \mathrm{E}-01$ & $1,30 \mathrm{E}-02$ & 100 & -03 & $\mathrm{E}-02$ \\
\hline $107 / 89$ & 63 & 1 & 180 & & 43 & $2,52 \mathrm{E}-01$ & $9,67 \mathrm{E}-01$ & 140 & $1 \mathrm{E}-01$ & $-1,27 \mathrm{E}+00$ \\
\hline $2 / 07 / 89$ & 63 & 1 & 220 & 0,83 & 83 & $3,35 \mathrm{E}-01$ & $3,92 \mathrm{E}+00$ & $180-220$ & -01 & $2,46 \mathrm{E}+00$ \\
\hline $07 / 89$ & 65 & 1 & 20 & .10 & 1,10 & $5,43 \mathrm{E}-02$ & $2,43 \mathrm{E}-04$ & & & \\
\hline & 65 & 1 & 60 & & & & & & & \\
\hline & 65 & 1 & 100 & & & E-02 & $2,45 \mathrm{E}-04$ & & & $\mathrm{E}-02$ \\
\hline $04 / 07 / 89$ & 65 & 1 & 140 & & 5,70 & $1,10 \mathrm{E}-01$ & $1,30 \mathrm{E}-02$ & $100-$ & $-1,07 \mathrm{E}-02$ & $-9,75 \mathrm{E}-02$ \\
\hline $4 / 07 / 89$ & 65 & 1 & 180 & 3,23 & $-48,23$ & $2,64 \mathrm{E}-01$ & $1,25 \mathrm{E}+00$ & 140. & $-5,45 \mathrm{E}-01$ & $-2,07 \mathrm{E}+00$ \\
\hline $107 / 89$ & 65 & 1 & 220 & 23 & & $5 \mathrm{E}-01$ & $1,28 \mathrm{E}+01$ & $180-220$ & $\mathrm{E}+00$ & $0,00 \mathrm{E}+00$ \\
\hline $7 / 89$ & 68 & 1 & 20 & & 35 & $5,40 \mathrm{E}-02$ & $2,35 \mathrm{E}-04$ & & & \\
\hline & 68 & 1 & 60 & & & $4,84 \mathrm{E}-02$ & $2,52 \mathrm{E}-04$ & & & $E-03$ \\
\hline & 68 & 1 & 100 & & & $6,22 \mathrm{E}-02$ & $8.13 \mathrm{E}-04$ & $60-100$ & & E-03 \\
\hline & 68 & 1 & 140 & & & & $4,92 \mathrm{E}-02$ & $100-140$ & $-3,02 \mathrm{E}-02$ & $-2,18 \mathrm{E}-01$ \\
\hline $07 / 07 / 89$ & 68 & 1 & 180 & $-219,83$ & $-39,83$ & $2,89 \mathrm{E}-01$ & $2,12 E+00$ & $140-180$ & $-3,55 \mathrm{E}-02$ & $-1,23 \mathrm{E}-01$ \\
\hline $07 / 07 / 89$ & 68 & 1 & 220 & $-224,03$ & $-4,03$ & $4,05 \mathrm{E}-01$ & $1,75 \mathrm{E}+01$ & $180-220$ & $1,84 \mathrm{E}+00$ & $4,53 \mathrm{E}+00$ \\
\hline $10 / 07 / 89$ & 71 & 1 & 20 & $-257,55$ & $-237,55$ & $5,01 \mathrm{E}-02$ & $1,28 \mathrm{E}-04$ & & & \\
\hline & 71 & 1 & 60 & & & $4,47 \mathrm{E}-02$ & $1.25 \mathrm{E}-04$ & & & $E-03$ \\
\hline $10 / 07 / 89$ & 71 & 1 & 100 & & $-157,63$ & $5,86 \mathrm{E}-02$ & $5,03 \mathrm{E}-04$ & $60-100$ & $-3,26 \mathrm{E}-04$ & $-5,56 \mathrm{E}-03$ \\
\hline $10 / 07 / 89$ & 71 & 1 & 140 & -239.40 & $-99,40$ & $1,16 \mathrm{E}-01$ & $1,76 \mathrm{E}-02$ & $100-140$ & $-8,04 \mathrm{E}-03$ & $-6,95 \mathrm{E}-02$ \\
\hline $10 / 07 / 89$ & 71 & 1 & 180 & $-232,43$ & $.52,43$ & $2,52 \mathrm{E}-01$ & $9,67 \mathrm{E}-01$ & $140-180$ & $-1,68 \mathrm{E}-01$ & $-6,69 \mathrm{E}-01$ \\
\hline $10 / 07 / 89$ & 71 & 1 & 220 & $-232,43$ & $-12,43$ & $3,79 \mathrm{E}-01$ & $8.89 \mathrm{E}+00$ & $180-220$ & $0,00 \mathrm{E}+00$ & $0,00 E+00$ \\
\hline
\end{tabular}


Tabela 1 (continuação)

\begin{tabular}{|c|c|c|c|c|c|c|c|c|c|c|}
\hline DATA & DIA & ÁREA & $\begin{array}{c}\mathrm{PROF} \\
\mathrm{cm}\end{array}$ & $\begin{array}{c}\begin{array}{c}\text { POT. HIDR } \\
\mathrm{cm}\end{array} \\
\end{array}$ & $\begin{array}{c}\text { POT. MAT } \\
\mathrm{cm}\end{array}$ & $\begin{array}{c}\theta \\
\mathrm{cm}^{3} / \mathrm{cm}^{3}\end{array}$ & $\begin{array}{c}\mathbf{K}(\theta) \\
\mathrm{cm} / \mathrm{dia}\end{array}$ & CAMADA & $\begin{array}{c}\mathbf{q} \\
\mathrm{cm} / \mathrm{dia} \\
\end{array}$ & $\begin{array}{c}v \\
\mathrm{~cm} / \mathrm{dia}\end{array}$ \\
\hline $12 / 07 / 89$ & 73 & 1 & 20 & $-270,15$ & $-250,15$ & $4,85 \mathrm{E}-02$ & $9,68 \mathrm{E}-05$ & & & \\
\hline $12 / 07 / 89$ & 73 & 1 & 60 & $-289,80$ & $-229,80$ & $4,39 E-02$ & $1,06 \mathrm{E}-04$ & $20-60$ & $5,21 \mathrm{E}-05$ & $1,19 \mathrm{E}-03$ \\
\hline $12 / 07 / 89$ & 73 & 1 & 100 & $-257,63$ & $-157,63$ & $5,86 \mathrm{E}-02$ & $5,03 \mathrm{E}-04$ & $60-100$ & $-4,05 \mathrm{E}-04$ & \\
\hline $12 / 07 / 89$ & 73 & 1 & 140 & $-239,40$ & & $1,16 \mathrm{E}-01$ & $1,76 \mathrm{E}-02$ & & $-8,04 \mathrm{E}-03$ & $-6,95 \mathrm{E}-02$ \\
\hline & 73 & 1 & 180 & & $-52,43$ & $2,52 \mathrm{E}-0 \mathrm{I}$ & $9,67 E-01$ & & $-1,68 \mathrm{E}-0 \mathrm{t}$ & $-6,69 \mathrm{E}-01$ \\
\hline $12 / 07 / 89$ & 73 & 1 & 220 & $-236,63$ & $-16,63$ & $3,58 \mathrm{E}-01$ & $5,96 \mathrm{E}+00$ & & $6,26 \mathrm{E}-01$ & $1,75 E+00$ \\
\hline $14 / 07 / 89$ & 75 & 1 & 20 & $-276,45$ & & & $8,45 \mathrm{E}-05$ & & & \\
\hline $14 / 07 / 89$ & 75 & 1 & 60 & $-289,80$ & $-229,80$ & $4,39 \mathrm{E}-02$ & $1,06 \mathrm{E}-04$ & $20-60$ & $3,54 \mathrm{E}-05$ & $07 \mathrm{E}-04$ \\
\hline $14 / 07 / 89$ & 75 & 1 & 100 & $-257,63$ & & & $5,03 \mathrm{E}-04$ & & $-4,05 \mathrm{E}-04$ & \\
\hline & 75 & 1 & 140 & & & & $1,76 \mathrm{E}-02$ & & $-8,04 \mathrm{E}-03$ & \\
\hline & 75 & 1 & 180 & & & & & & $8 \mathrm{E}-01$ & $9 E-01$ \\
\hline & 75 & 1 & 220 & $-232,43$ & & $3,79 \mathrm{E}-01$ & $8,89 \mathrm{E}+00$ & & $0,00 \mathrm{E}+00$ & $0,00 \mathrm{E}+00$ \\
\hline & 77 & 1 & 20 & & & & $5.75 \mathrm{E}-05$ & & & \\
\hline $16 / 07 / 89$ & 77 & 1 & 60 & & & & $7,75 \mathrm{E}-05$ & & $\mathrm{E}-05$ & $E-04$ \\
\hline & 77 & 1 & 100 & & & & & & 04 & \\
\hline & 77 & 1 & 140 & & & & & & E-02 & \\
\hline & 77 & 1 & 180 & & & & $9,67 \mathrm{E}-01$ & & E-01 & \\
\hline & 77 & 1 & 220 & & & & $3,92 E+00$ & & & \\
\hline & 79 & 1 & 20 & & & -02 & & & & \\
\hline & 79 & 1 & 60 & & & & & & & \\
\hline & 79 & 1 & 100 & & & & & & -04 & \\
\hline & 79 & 1 & 140 & & & & & & -02 & 01 \\
\hline & 79 & 1 & 180 & & & & & & & \\
\hline & 79 & 1 & 220 & & & & & & & \\
\hline & 82 & 1 & 20 & & -29 & 4,41 & & & & \\
\hline & 82 & 1 & 60 & & & & & & & \\
\hline & 82 & 1 & 100 & & & & & & -04 & \\
\hline & 82 & 1 & 140 & & & & 1,76 & & & \\
\hline & 82 & 1 & 180 & & & & & & & \\
\hline & 82 & 1 & 220 & & & & 8,89 & & & \\
\hline & 86 & 1 & 20 & & & & & & & \\
\hline & 86 & 1 & & & & & & & & \\
\hline & 86 & 1 & 100 & & & & & & & -03 \\
\hline & 86 & 1 & 140 & & & & & & & \\
\hline & 86 & 1 & 180 & & & & & & & \\
\hline 107/89 & 86 & 1 & 220 & & & & 8,89 & & & \\
\hline & 88 & 1 & 20 & & & & & & & \\
\hline & 88 & 1 & & & & & & & & \\
\hline & 88 & 1 & 100 & & & 5,5 & & & & 02 \\
\hline & 88 & 1 & 140 & & & & 1,76 & & & \\
\hline $27 / 07 / 89$ & 88 & 1 & 180 & & & & $9,67 \mathrm{E}-01$ & & & \\
\hline & 88 & 1 & 220 & & & & $3,92 \mathrm{E}+00$ & & & \\
\hline & 90 & 1 & & & & & & & & \\
\hline & 90 & 1 & & & & & & & & \\
\hline & 90 & 1 & 100 & & & $5,57 \mathrm{E}-02$ & $3,23 \mathrm{E}-04$ & & $-7,22 \mathrm{E}-04$ & \\
\hline & 90 & 1 & 140 & & & & $2,44 \mathrm{E}-02$ & & $-2,24 \mathrm{E}-02$ & \\
\hline $29 / 07 / 89$ & 90 & 1 & 180 & & & & $9,67 \mathrm{E}-01$ & & & \\
\hline & 90 & 1 & 220 & & & & & & & \\
\hline & 3 & 2 & 20 & & & & & & & \\
\hline & 3 & 2 & 60 & & & & & & & \\
\hline & 3 & 2 & 100 & & & & $5,59 \mathrm{E}-03$ & & & \\
\hline & 3 & 2 & 140 & & & & $3,28 \mathrm{E}-01$ & $100-140$ & $-8,60 \mathrm{E}-02$ & $-4,35 \mathrm{E}-01$ \\
\hline $03 / 05 / 89$ & 3 & 2 & 180 & & & $3,30 \mathrm{E}-01$ & $4,86 \mathrm{E}+00$ & & $1,73 \mathrm{E}+00$ & $5,26 \mathrm{E}+00$ \\
\hline $03 / 05 / 89$ & 3 & 2 & 220 & & & 01 & $3,38 \mathrm{E}+00$ & & 01 & \\
\hline & 5 & 2 & 20 & & & & & & & \\
\hline & 5 & 2 & 60 & & & & & & & \\
\hline & 5 & 2 & 100 & & & & $1,02 \mathrm{E}-02$ & & & \\
\hline $05 / 05 / 89$ & 5 & 2 & 140 & $-194,97$ & $-54,97$ & $1,92 \mathrm{E}-01$ & $2,78 \mathrm{E}-01$ & $100-140$ & $1,46 \mathrm{E}-02$ & $7,62 \mathrm{E}-02$ \\
\hline $05 / 05 / 89$ & 5 & 2 & 180 & & $-14,97$ & $3,65 \mathrm{E}-01$ & $1,04 \mathrm{E}+01$ & $140-180$ & $0,00 \mathrm{E}+00$ & $0,00 \mathrm{E}+00$ \\
\hline $05 / 05 / 89$ & 5 & 2 & 220 & $-194,55$ & 25,45 & $3,10 \mathrm{E}-01$ & $2,46 \mathrm{E}+00$ & $180-220$ & $-2,58 \mathrm{E}-02$ & $-8,35 \mathrm{E}-02$ \\
\hline
\end{tabular}


Tabela 1 (continação)

\begin{tabular}{|c|c|c|c|c|c|c|c|c|c|c|}
\hline DATA & DIA & ÁREA & $\begin{array}{c}\text { PROF } \\
\mathrm{cm}\end{array}$ & $\begin{array}{c}\text { POT. HIDR } \\
\mathrm{cm}\end{array}$ & POT. MAT & $\begin{array}{c}\theta \\
\mathrm{cm}^{3} / \mathrm{cm}^{3}\end{array}$ & $\begin{array}{c}\mathbf{K}(\theta) \\
\mathrm{cm} / \mathrm{dia}\end{array}$ & CAMADA & $\underset{\mathrm{cm} / \mathrm{dia}}{\mathrm{q}}$ & $\begin{array}{c}v \\
\mathrm{~cm} / \text { dia }\end{array}$ \\
\hline $08 / 05 / 89$ & 8 & 2 & 20 & & & & & & & \\
\hline $8 / 05 / 89$ & 8 & 2 & 60 & 44,95 & $-184,95$ & $5,09 \mathrm{E}-02$ & $3,80 \mathrm{E}-04$ & & $2,33 \mathrm{E}-03$ & $4,57 \mathrm{E}-02$ \\
\hline $08 / 05 / 89$ & 8 & 2 & 100 & $-180,27$ & $-80,27$ & $1,04 \mathrm{E}-01$ & $2,28 \mathrm{E}-02$ & $60-100$ & $-3,68 \mathrm{E}-02$ & $-3,53 \mathrm{E}-01$ \\
\hline $08 / 05 / 89$ & 8 & 2 & 140 & $-180,27$ & 40,27 & $2,43 \mathrm{E}-01$ & $9,45 \mathrm{E}-01$ & & $0,00 \mathrm{E}+00$ & $0,00 \mathrm{E}+00$ \\
\hline $08 / 05 / 89$ & 8 & 2 & 180 & $-188,25$ & $-8,25$ & $3,77 \mathrm{E}-01$ & $1,51 \mathrm{E}+01$ & $40-180$ & $3,02 \mathrm{E}+00$ & $8,00 \mathrm{E}+00$ \\
\hline & 8 & 2 & 220 & 5,10 & & $2,62 \mathrm{E}-01$ & $9,77 \mathrm{E}-01$ & & $-7,69 \mathrm{E}-02$ & $-2,94 \mathrm{E}-01$ \\
\hline $5 / 89$ & 10 & 2 & 20 & .50 & & $1,40 \mathrm{E}-01$ & $6,59 \mathrm{E}-02$ & & & \\
\hline $10 / 05 / 89$ & 10 & 2 & 60 & $-251,25$ & $-191,25$ & $4,97 \mathrm{E}-02$ & $3,12 \mathrm{E}-04$ & & $1,24 \mathrm{E}-03$ & $2,50 \mathrm{E}-02$ \\
\hline $10 / 05 / 89$ & 10 & 2 & 100 & $-176,07$ & & $1,10 \mathrm{E}-01$ & $3,05 \mathrm{E}-02$ & & $-5,73 \mathrm{E}-02$ & $1 \mathrm{E}-01$ \\
\hline $10 / 05 / 89$ & 10 & 2 & 140 & $-180,27$ & $-40,27$ & $2,43 \mathrm{E}-01$ & $9,45 \mathrm{E}-01$ & & $9,92 \mathrm{E}-02$ & $9 \mathrm{E}-01$ \\
\hline & 10 & 2 & 180 & 1,40 & & & $1,28 \mathrm{E}+01$ & & $3,56 \mathrm{E}+00$ & $E+00$ \\
\hline & 10 & 2 & 220 & & & & $9,77 \mathrm{E}-01$ & & $4 \mathrm{E}-01$ & $\mathrm{E}-01$ \\
\hline $05 / 89$ & 12 & 2 & 20 & 6,35 & & & $2,75 \mathrm{E}-02$ & & & \\
\hline $12 / 05 / 89$ & 12 & 2 & 60 & 3,85 & & $4,75 \mathrm{E}-02$ & $2,15 \mathrm{E}-04$ & & $\mathrm{E}-04$ & $1,78 \mathrm{E}-02$ \\
\hline $12 / 05 / 89$ & 12 & 2 & 100 & 2,37 & & & $1,98 \mathrm{E}-02$ & & E-02 & $6 \mathrm{E}-01$ \\
\hline $05 / 89$ & 12 & 2 & 140 & .87 & & & $3,28 \mathrm{E}-01$ & & $\mathrm{E}-02$ & $E-01$ \\
\hline & 12 & 2 & 180 & & & & $7,29 \mathrm{E}+00$ & & $E+00$ & $+\infty$ \\
\hline $12 / 05 / 89$ & 12 & 2 & 220 & 40 & & & $1,80 \mathrm{E}+00$ & & $E-01$ & +00 \\
\hline $15 / 05 / 89$ & 15 & 2 & 20 & 5,80 & & & $1,62 \mathrm{E}-02$ & & & \\
\hline $15 / 05 / 89$ & 15 & 2 & 60 & & & E-02 & $3,85 \mathrm{E}-04$ & & $\mathrm{E}-03$ & $\mathrm{E}-02$ \\
\hline & 15 & 2 & 100 & & & & $2,63 \mathrm{E}-02$ & & $\mathrm{E}-02$ & Q-01 \\
\hline & 15 & 2 & 140 & & & & $3,68 \mathrm{E}-01$ & & & \\
\hline & 15 & 2 & 180 & & & & $1,07 \mathrm{E}+01$ & & & +00 \\
\hline & 15 & 2 & 220 & & & & $2,46 \mathrm{E}+00$ & & +00 & +00 \\
\hline $5 / 89$ & 17 & 2 & 20 & & & & $4,18 \mathrm{E}-03$ & & & \\
\hline & 17 & 2 & 60 & 20 & & -02 & $9,98 \mathrm{E}-05$ & & E-04 & -03 \\
\hline & 17 & 2 & 0 & & & & $2,63 \mathrm{E}-02$ & & $8-02$ & -01 \\
\hline & 17 & 2 & & & & & $2,78 \mathrm{E}-01$ & & & \\
\hline & 17 & 2 & 180 & & & & $7,29 \mathrm{E}+00$ & & +00 & $3+00$ \\
\hline & 17 & 2 & 220 & & & & $4,64 \mathrm{E}+00$ & & $+\infty$ & $a+00$ \\
\hline & 19 & 2 & 2 & & & & $1,75 \mathrm{E}-03$ & & & \\
\hline & 19 & 2 & 6 & & & -02 & E-05 & & & \\
\hline & 19 & 2 & 10 & & & & $\mathrm{E}-02$ & & -02 & -01 \\
\hline & 19 & 2 & 140 & & & & $8 \mathrm{E}-01$ & & & -01 \\
\hline & 19 & 2 & 180 & & & & $7,29 \mathrm{E}+00$ & & & +00 \\
\hline $5 / 89$ & 19 & 2 & 220 & & & $E-01$ & $3,38 \mathrm{E}+00$ & & & -01 \\
\hline & 22 & 2 & 20 & & & & $1,01 \mathrm{E}-03$ & & & \\
\hline & 22 & 2 & 6 & & & & $6,29 \mathrm{E}-05$ & & & \\
\hline & 22 & 2 & 100 & & & & E-02 & & & \\
\hline & 22 & 2 & 140 & & & & $1,74 \mathrm{E}-01$ & & -02 & -01 \\
\hline & 22 & 2 & 180 & & & & $5,96 \mathrm{E}+00$ & & & +00 \\
\hline & 22 & 2 & 220 & & & & $4,64 \mathrm{E}+00$ & & $\mathrm{E}-01$ & $\pm+\infty$ \\
\hline & 24 & 2 & 20 & & & & $8,25 \mathrm{E}-04$ & & & \\
\hline & 24 & 2 & 60 & & & & $E-05$ & & & \\
\hline & 24 & 2 & 100 & & & & $1,32 \mathrm{E}-02$ & & $\mathrm{E}-02$ & $E-01$ \\
\hline $5 / 89$ & 24 & 2 & 140 & & & & $2,78 \mathrm{E}-01$ & & -02 & 201 \\
\hline $5 / 89$ & 24 & 2 & 180 & .15 & & 8.01 & $4,86 \mathrm{E}+00$ & & $+\infty$ & +00 \\
\hline & 24 & 2 & 220 & & & & $6,34 \mathrm{E}+00$ & & $\mathrm{E}-01$ & $2+00$ \\
\hline & 26 & 2 & 20 & & & & & & & \\
\hline & 26 & 2 & 60 & & & & $2,94 \mathrm{E}-05$ & & & \\
\hline & 26 & 2 & 100 & & & & & & $E-02$ & \\
\hline $26 / 05 / 89$ & 26 & 2 & 140 & & & $1,70 \mathrm{E}-01$ & $1,49 \mathrm{E}-01$ & & $3,92 \mathrm{E}-02$ & $2,30 \mathrm{E}-01$ \\
\hline $26 / 05 / 89$ & 26 & 2 & 180 & 5,60 & & $2,99 \mathrm{E}-01$ & $2,62 \mathrm{E}+00$ & & E-01 & $2,89 \mathrm{E}+00$ \\
\hline & 26 & 2 & 220 & & & & $1,13 E+01$ & & $2+00$ & $8 E+00$ \\
\hline & 29 & & 20 & & & & $3,57 \mathrm{E}-04$ & & & \\
\hline & 29 & 2 & 60 & & & & $2,70 \mathrm{E}-05$ & & & \\
\hline & 29 & 2 & 100 & & & & $8,99 \mathrm{E}-03$ & & $-3,46 \mathrm{E}-02$ & $-3,90 \mathrm{E}-01$ \\
\hline & 29 & 2 & 140 & $-197,07$ & & $1,86 \mathrm{E}-01$ & $2,37 \mathrm{E}-01$ & $100-140$ & $1,24 \mathrm{E}-02$ & $6,69 \mathrm{E}-02$ \\
\hline & 29 & 2 & 180 & & & $3,09 \mathrm{E}-01$ & $3,21 \mathrm{E}+00$ & $140-180$ & $1,32 \mathrm{E}+00$ & $4,26 \mathrm{E}+00$ \\
\hline $29 / 05 / 89$ & 29 & 2 & 220 & $-207,15$ & 12,85 & $3,77 \mathrm{E}-01$ & $8.56 E+00$ & $180-220$ & $-1,35 \mathrm{E}+00$ & $-3,58 \mathrm{E}+00$ \\
\hline
\end{tabular}


Tabela 1 (continuação)

\begin{tabular}{|c|c|c|c|c|c|c|c|c|c|c|}
\hline DATA & DIA & REA & $\begin{array}{c}\text { PROF } \\
\mathrm{cm}\end{array}$ & $\begin{array}{c}\text { POT. HIDR } \\
\mathrm{cm}\end{array}$ & $\begin{array}{c}\text { POT. MAT } \\
\mathrm{cm}\end{array}$ & $\begin{array}{c}\theta \\
\mathrm{cm}^{3} / \mathrm{cm}^{3}\end{array}$ & $\begin{array}{c}\mathrm{K}(\theta) \\
\mathrm{cm} / \mathrm{dja}\end{array}$ & CAMADA & $\begin{array}{c}\mathbf{q} \\
\mathrm{cm} / \mathrm{dia}\end{array}$ & $\begin{array}{c}v \\
\mathrm{~cm} / \mathrm{dia}\end{array}$ \\
\hline $1 / 05 / 89$ & 31 & 2 & 20 & $-222,90$ & $-202,90$ & $5,58 \mathrm{E}-02$ & $3,01 \mathrm{E}-04$ & & & \\
\hline $31 / 05 / 89$ & 31 & 2 & 60 & $-358,35$ & $-298,35$ & $3,80 \mathrm{E}-02$ & $2,28 \mathrm{E}-05$ & & $7,70 \mathrm{E}-05$ & $2,03 E-03$ \\
\hline $31 / 05 / 89$ & 31 & 2 & 100 & $-194,97$ & $-94,97$ & $8,88 \mathrm{E}-02$ & $8,99 \mathrm{E}-03$ & $60-100$ & $-3,67 \mathrm{E}-02$ & $-4,14 \mathrm{E}-01$ \\
\hline $31 / 05 / 89$ & 31 & 2 & 140 & $-201,27$ & $-61,27$ & $1,75 \mathrm{E}-01$ & $1,74 \mathrm{E}-01$ & & $2,73 E-02$ & $1,56 \mathrm{E}-01$ \\
\hline $1 / 05 / 89$ & 31 & & 180 & $-210,30$ & $-30,30$ & $3,20 \mathrm{E}-01$ & $3,95 E+00$ & & $8,92 \mathrm{E}-01$ & $2,79 \mathrm{E}+00$ \\
\hline & 31 & 2 & 220 & & & & $1,46 \mathrm{E}+01$ & & $1,15 E+00$ & $2,88 \mathrm{E}+00$ \\
\hline $02 / 06 / 89$ & 33 & 2 & 20 & & -193 & $5,78 \mathrm{E}-02$ & $3,89 \mathrm{E}-04$ & & & \\
\hline $02 / 06 / 89$ & 33 & 2 & 60 & & & $3,84 \mathrm{E}-02$ & $2,58 \mathrm{E}-05$ & & $8,94 \mathrm{E}-05$ & $2,33 \mathrm{E}-03$ \\
\hline $02 / 06 / 89$ & 33 & 2 & 100 & & & $9,69 \mathrm{E}-02$ & $1,50 \mathrm{E}-02$ & & $-6,22 \mathrm{E}-02$ & $-6,42 \mathrm{E}-01$ \\
\hline & 33 & 2 & 140 & & & $1,46 \mathrm{E}-01$ & $6,48 \mathrm{E}-02$ & & $4,76 \mathrm{E}-02$ & $\mathrm{E}-01$ \\
\hline & 33 & 2 & 180 & & & & $2,62 \mathrm{E}+00$ & & & \\
\hline & 33 & 2 & 220 & & & & $1,13 E+01$ & & $3+00$ & $E+00$ \\
\hline $05 / 06 / 89$ & 36 & 2 & 20 & & & E-02 & $5,59 \mathrm{E}-04$ & & & \\
\hline $05 / 06 / 89$ & 36 & 2 & 60 & & & & $2,58 \mathrm{E}-05$ & & $9,76 \mathrm{E}-05$ & $2,54 \mathrm{E}-03$ \\
\hline & 36 & 2 & 100 & & & & $1,72 \mathrm{E}-02$ & & $\mathrm{E}-02$ & E-01 \\
\hline & 36 & 2 & 140 & & & & $2,02 \mathrm{E}-01$ & & $E-02$ & \\
\hline & 36 & 2 & 30 & & & & $4,86 \mathrm{E}+00$ & & & \\
\hline & 36 & 2 & 220 & & & & $4,64 \mathrm{E}+00$ & & & +00 \\
\hline $07 / 06 / 89$ & 38 & 2 & 20 & & & $5,46 \mathrm{E}-02$ & $2,55 \mathrm{E}-04$ & & & \\
\hline & 38 & 2 & 60 & & & & $1,33 \mathrm{E}-05$ & & & $E-03$ \\
\hline & 38 & 2 & 100 & & & & $\mathrm{E}-03$ & & -02 & -01 \\
\hline & 38 & 2 & 40 & & & & & & & \\
\hline & 38 & 2 & 180 & & & & $2 \mathrm{E}+00$ & & & +00 \\
\hline & 38 & 2 & 220 & & & & $8,56 \mathrm{E}+00$ & & $+\infty$ & $3+00$ \\
\hline & 40 & 2 & 20 & & & & $1,72 \mathrm{E}-04$ & & & \\
\hline & 40 & 2 & 60 & & & & $\mathrm{E}-05$ & & $E-05$ & -03 \\
\hline & 40 & 2 & & & & & & & & \\
\hline & 40 & 2 & & & & & & & & \\
\hline & 40 & 2 & 180 & & & & $E+00$ & & & $E+00$ \\
\hline & 40 & 2 & 220 & & & & $\mathrm{E}+01$ & & & \\
\hline 189 & 43 & 2 & 20 & & & 5,2 & 1,7 & & & \\
\hline & 43 & 2 & 6 & & & & 05 & & 04 & -03 \\
\hline & 43 & 2 & 10 & & & & $\mathrm{E}-03$ & & & \\
\hline & 43 & 2 & 140 & & & & E-01 & & & \\
\hline & 43 & 2 & 180 & & & & $\mathrm{E}+00$ & & & $E+00$ \\
\hline & 43 & 2 & 220 & & & & $\mathrm{E}+01$ & & & \\
\hline & 45 & 2 & 20 & & & & & & & \\
\hline & 45 & 2 & 6 & & & & & & & \\
\hline & 45 & 2 & 10 & & & & & & & \\
\hline & 45 & 2 & & & & & & & & \\
\hline $6 / 89$ & 45 & 2 & 180 & & & & $3,21 \mathrm{E}+00$ & & & $+\infty$ \\
\hline & 45 & 2 & 220 & & & & $1,46 \mathrm{E}+01$ & & & \\
\hline & 47 & 2 & 20 & & & & & & & \\
\hline & 47 & 2 & 60 & & & & 9,5 & & & \\
\hline & 47 & 2 & 100 & & & & & & & \\
\hline & 47 & 2 & 140 & & & & & & & \\
\hline & 47 & 2 & 180 & & & & $9,71 \mathrm{E}-01$ & & $7,04 \mathrm{E}-01$ & $2,79 \mathrm{E}+00$ \\
\hline $6 / 89$ & 47 & 2 & 220 & & & & $1,52 \mathrm{E}+01$ & & $-2,39 \mathrm{E}+00$ & $-5,96 \mathrm{E}+00$ \\
\hline & 50 & 2 & 20 & & & & $1,72 \mathrm{E}-04$ & & & \\
\hline & 50 & 2 & 60 & & & & & & & \\
\hline & 50 & 2 & 100 & & & & $1,32 \mathrm{E}-02$ & & & \\
\hline & 50 & 2 & 140 & & & & & & & \\
\hline $19 / 06 / 89$ & 50 & 2 & 180 & & & & $2,13 \mathrm{E}+00$ & & & $1,47 \mathrm{E}+00$ \\
\hline $19 / 06 / 89$ & 50 & 2 & 220 & & & $4,01 \mathrm{E}-01$ & $1,52 \mathrm{E}+01$ & $180-220$ & $2,39 E+00$ & $5,96 \mathrm{E}+00$ \\
\hline $21 / 06 / 89$ & 52 & 2 & 20 & & & & & & & \\
\hline & 52 & 2 & 60 & & & & $5,87 \mathrm{E}-06$ & & & $1,85 \mathrm{E}-03$ \\
\hline $21 / 06 / 89$ & 52 & 2 & 100 & & & & & & & $-3,55 \mathrm{E}+00$ \\
\hline $21 / 06 / 89$ & 52 & 2 & 140 & & & & $2,47 \mathrm{E}+00$ & & & \\
\hline $21 / 06 / 89$ & 52 & 2 & 180 & & & $3,09 \mathrm{E}-01$ & $3,21 \mathrm{E}+\infty 0$ & $140-180$ & $3,51 E+00$ & $1,13 \mathrm{E}+0 \mathrm{I}$ \\
\hline $21 / 06 / 89$ & 52 & 2 & 220 & $-199,17$ & 20.83 & $3,35 \mathrm{E}-01$ & $3,92 \mathrm{E}+00$ & $180-220$ & $-1,40 \mathrm{E}+00$ & $-4,18 \mathrm{E}+00$ \\
\hline
\end{tabular}


Tabela 1 (continuação)

\begin{tabular}{|c|c|c|c|c|c|c|c|c|c|c|}
\hline DATA & DIA & ĀREA & $\begin{array}{c}\text { PROF } \\
\mathrm{cm}\end{array}$ & {$\left[\begin{array}{c}\text { POT. HIDR } \\
\mathrm{cm}\end{array}\right.$} & $\begin{array}{c}\text { POT MAT } \\
\mathrm{cm}\end{array}$ & $\begin{array}{c}\theta \\
\mathrm{cm}^{3} / \mathrm{cm}^{3}\end{array}$ & $\begin{array}{c}\mathbf{K}(\theta) \\
\mathrm{cm} / \mathrm{dia} \\
\end{array}$ & CAMADA & $\begin{array}{c}\mathbf{q} \\
\mathrm{cm} / \mathrm{dia} \\
\end{array}$ & $\begin{array}{c}v \\
\mathrm{~cm} / \mathrm{dia} \\
\end{array}$ \\
\hline $23 / 06 / 89$ & 54 & 2 & 20 & $-200,85$ & $-180,85$ & $6,08 \mathrm{E}-02$ & $5,59 \mathrm{E}-04$ & & & \\
\hline $23 / 06 / 89$ & 54 & 2 & 60 & $-447,80$ & $-387,80$ & $3,41 \mathrm{E}-02$ & $4,83 E-06$ & $20-60$ & $2,98 \mathrm{E}-05$ & $8,74 \mathrm{E}-04$ \\
\hline $23 / 06 / 89$ & 54 & 2 & 100 & $-211,77$ & $-111,77$ & $7,67 \mathrm{E}-02$ & $3,60 \mathrm{E}-03$ & $60-100$ & $-2,12 \mathrm{E}-02$ & $-2,77 \mathrm{E}-01$ \\
\hline $23 / 06 / 89$ & 54 & 2 & 140 & $-215,97$ & $-75,97$ & $1,46 \mathrm{E}-01$ & $6,48 \mathrm{E}-02$ & $100-140$ & $6,80 \mathrm{E}-03$ & $4,67 \mathrm{E}-02$ \\
\hline $23 / 06 / 89$ & 54 & 2 & 180 & $-213,45$ & $-33,45$ & $3,09 \mathrm{E}-01$ & $3,21 \mathrm{E}+00$ & & $-2,03 \mathrm{E}-01$ & $-6,55 \mathrm{E}-01$ \\
\hline & 54 & 2 & 220 & & 4,03 & $4,05 \mathrm{E}-0 \mathrm{1}$ & $1,75 E+01$ & & $1,10 \mathrm{E}+00$ & $2,72 \mathrm{E}+00$ \\
\hline $26 / 06 / 89$ & 57 & 2 & 20 & $-219,75$ & $-199,75$ & $5,64 \mathrm{E}-02$ & $3,27 \mathrm{E}-04$ & & & \\
\hline $26 / 06 / 89$ & 57 & 2 & 60 & $-460,40$ & $-400,40$ & $3,37 \mathrm{E}-02$ & $4,00 \mathrm{E}-06$ & $20-60$ & $2,40 \mathrm{E}-05$ & $7,13 \mathrm{E}-04$ \\
\hline $26 / 06 / 89$ & 57 & 2 & 100 & $.232,77$ & $-132,77$ & $6,65 \mathrm{E}-02$ & $1,35 \mathrm{E}-03$ & $60-100$ & $-7,68 \mathrm{E}-03$ & $5 \mathrm{E}-01$ \\
\hline & 57 & 2 & 140 & & & $1,53 \mathrm{E}-01$ & $8,46 \mathrm{E}-02$ & & $\mathrm{E}-02$ & $\mathrm{E}-01$ \\
\hline & 57 & 2 & 180 & & & $3,66 \mathrm{E}-01$ & $1,07 \mathrm{E}+01$ & & $\mathrm{OE}+00$ & $5 E+01$ \\
\hline $26 / 0$ & 57 & 2 & 220 & & $-0,17$ & $4,08 \mathrm{E}-01$ & $2,16 \mathrm{E}+01$ & & $1,38 \mathrm{E}+01$ & $3,40 \mathrm{E}+01$ \\
\hline $28 / 06 / 89$ & 59 & 2 & 20 & & & $5,30 \mathrm{E}-02$ & $2,01 \mathrm{E}-04$ & & & \\
\hline $28 / 06 / 89$ & 59 & 2 & 60 & $-460,40$ & & $3,37 \mathrm{E}-02$ & $4,00 \mathrm{E}-06$ & & & $6,57 \mathrm{E}-04$ \\
\hline $28 / 06 / 89$ & 59 & 2 & 100 & & & $6,82 \mathrm{E}-02$ & $1,62 \mathrm{E}-03$ & & & $E-01$ \\
\hline & 59 & 2 & 140 & & & $8-01$ & 1,4 & & & $E-01$ \\
\hline & 59 & 2 & 180 & & & $8-01$ & $4,86 \mathrm{E}+00$ & & & $\mathrm{E}+00$ \\
\hline $28 / 06 / 89$ & 59 & 2 & 220 & & 12 & $3,79 \mathrm{E}-01$ & $8,89 \mathrm{E}+00$ & & & \\
\hline $30 / 06 / 89$ & 61 & 2 & 20 & & & $4,93 \mathrm{E}-02$ & $1,11 \mathrm{E}-04$ & & & \\
\hline $30 / 06 / 89$ & 61 & 2 & 60 & 47 & -41 & $3,34 \mathrm{E}-02$ & 3,3 & & & \\
\hline & 61 & 2 & 100 & & & -02 & & & & \\
\hline & 61 & 2 & 140 & & & $2-01$ & $8,46 \mathrm{E}-02$ & & & $2-01$ \\
\hline & 61 & 2 & 180 & & & $E-01$ & $2,13 \mathrm{E}+00$ & & & $\pm+\infty$ \\
\hline$/ 06 / 89$ & 61 & 2 & 220 & -22 & & $\mathrm{E}-0 \mathrm{ll}$ & $1,52 \mathrm{E}+01$ & & & \\
\hline 189 & 63 & 2 & 20 & & 10 & -02 & & & & \\
\hline & 63 & 2 & 60 & & & -02 & & & & \\
\hline 89 & 63 & 2 & 100 & & & $8-02$ & & & & -02 \\
\hline $02 / 07 / 89$ & 63 & 2 & 140 & & & E-01 & & & & -01 \\
\hline $02 / 07 / 89$ & 63 & 2 & 180 & & & $8-01$ & & & & -01 \\
\hline $02 / 07 / 89$ & 63 & 2 & 220 & & & $3,79 \mathrm{E}-01$ & $8,96 \mathrm{E}+00$ & & & \\
\hline $04 / 07 / 89$ & 65 & 2 & 20 & & & & & & & \\
\hline & 65 & 2 & 60 & & & & & & & \\
\hline & 65 & 2 & 100 & & & 5,56 & & & & \\
\hline & 65 & 2 & 140 & & & & 1,99 & & & \\
\hline $04 / 07 / 89$ & 65 & 2 & 180 & -23 & & $8-01$ & 9,71 & 140 & & \\
\hline & 65 & 2 & 220 & & & 01 & 8,96 & & & \\
\hline & 68 & 2 & 20 & & & & & & & \\
\hline & 68 & 2 & 60 & & & & 2,4 & & & -03 \\
\hline $07 / 07 / 89$ & 68 & 2 & 100 & & & $6,35 \mathrm{E}-02$ & $9,49 \mathrm{E}-04$ & & & $2-02$ \\
\hline $07 / 07 / 89$ & 68 & 2 & 140 & & & $1,53 \mathrm{E}-01$ & $8,46 \mathrm{E}-02$ & 100 & & $E-01$ \\
\hline $07 / 07 / 89$ & 68 & 2 & 180 & & & $2,89 \mathrm{E}-01$ & 2,1 & & & \\
\hline & 68 & 2 & 220 & & & & 2,10 & & & +00 \\
\hline & 71 & 2 & 20 & & & 4,5 & & & & \\
\hline $10 / 07 / 89$ & 71 & 2 & 60 & & & $3,71 \mathrm{E}-02$ & $1,63 \mathrm{E}-05$ & & & -04 \\
\hline $10 / 07 / 89$ & 71 & 2 & 100 & & & $5,75 \mathrm{E}-02$ & $4,27 \mathrm{E}-04$ & & & $-2,11 E-02$ \\
\hline $10 / 07 / 89$ & 71 & 2 & 140 & & & & $1,99 \mathrm{E}-02$ & 100 & & \\
\hline $10 / 07 / 89$ & 71 & 2 & 80 & & & & $9,71 \mathrm{E}-01$ & & & \\
\hline & 71 & 2 & 220 & & & & $8,96 \mathrm{E}+00$ & 180 & & \\
\hline & 73 & 2 & 20 & & & $4,52 \mathrm{E}-02$ & $5,08 \mathrm{E}-05$ & & & \\
\hline $12 / 07 / 89$ & 73 & 2 & 60 & & & $3,68 \mathrm{E}-02$ & $1,51 \mathrm{E}-05$ & & & $8,01 \mathrm{E}-04$ \\
\hline $12 / 07 / 89$ & 73 & 2 & 100 & $-266,37$ & $-166,37$ & $5,65 \mathrm{E}-02$ & $3,69 \mathrm{E}-04$ & $60-100$ & $-1,05 E-03$ & $-1,85 \mathrm{E}-02$ \\
\hline $12 / 07 / 89$ & 73 & 2 & 40 & $-236,97$ & & $1,18 \mathrm{E}-01$ & $1,99 \mathrm{E}-02$ & 100 & & $-1,24 \mathrm{E}-01$ \\
\hline $12 / 07 / 89$ & 73 & 2 & & & & & & & & \\
\hline $12 / 07 / 89$ & 73 & 2 & 220 & & & $3,79 \mathrm{E}-01$ & $8,96 \mathrm{E}+00$ & $180-220$ & $-1,41 \mathrm{E}+00$ & $-3,72 \mathrm{E}+00$ \\
\hline $14 / 07 / 89$ & 75 & 2 & 20 & & $-264,00$ & $4,70 \mathrm{E}-02$ & $7,22 \mathrm{E}-05$ & & & \\
\hline $14 / 07 / 89$ & 75 & 2 & 60 & & & $3,68 \mathrm{E}-02$ & $1,51 \mathrm{E}-05$ & & & \\
\hline $14 / 07 / 89$ & 75 & 2 & 100 & $-253,77$ & $-153,77$ & $5,96 \mathrm{E}-02$ & $5,81 \mathrm{E}-04$ & $60-100$ & $-1,83 \mathrm{E}-03$ & $-3,07 \mathrm{E}-02$ \\
\hline $14 / 07 / 89$ & 75 & 2 & 140 & & & $1,14 \mathrm{E}-01$ & $1,62 \mathrm{E}-02$ & $100-140$ & $-5,09 \mathrm{E}-03$ & $-4,47 \mathrm{E}-02$ \\
\hline $14 / 07 / 89$ & 75 & 2 & 180 & & & & $4,40 \mathrm{E}-01$ & $140-180$ & $5,54 \mathrm{E}-02$ & $2.53 \mathrm{E}-01$ \\
\hline $14 / 07 / 89$ & 75 & 2 & 220 & $-246,20$ & $-26,20$ & $3,06 \mathrm{E}-01$ & $2,28 \mathrm{E}+00$ & $180-220$ & $0,00 \mathrm{E}+00$ & $0,00 \mathrm{E}+00$ \\
\hline
\end{tabular}


Tabela 1 (continuação)

\begin{tabular}{|c|c|c|c|c|c|c|c|c|c|c|}
\hline DATA & DIA & ARE & $\begin{array}{c}\text { PROF } \\
\mathbf{c m}\end{array}$ & $\begin{array}{c}\text { POT. HIDR } \\
\mathrm{cm}\end{array}$ & $\begin{array}{c}\text { POT. MAT } \\
\mathrm{cm}\end{array}$ & $\begin{array}{c}\theta \\
\mathrm{cm}^{3} / \mathrm{cm}^{3}\end{array}$ & $\begin{array}{c}\mathbf{K}(\theta) \\
\mathrm{cm} / \mathrm{dia}\end{array}$ & CAMADA & $\begin{array}{c}q \\
\mathrm{~cm} / \mathrm{dia} \\
\end{array}$ & $\begin{array}{c}v \\
\mathrm{~cm} / \mathrm{dia}\end{array}$ \\
\hline $16 / 07 / 89$ & 77 & 2 & 20 & $-331,90$ & $-311,90$ & $4,28 \mathrm{E}-02$ & $2,92 \mathrm{E}-05$ & & & \\
\hline $16 / 07 / 89$ & 77 & 2 & 60 & $-392,37$ & $-332,37$ & $3,62 \mathrm{E}-02$ & $1,20 \mathrm{E}-0 \mathrm{~s}$ & $20-60$ & $1,82 \mathrm{E}-05$ & $5,02 \mathrm{E}-04$ \\
\hline $16 / 07 / 89$ & 77 & 2 & 100 & $-266,37$ & $-166,37$ & $5,65 \mathrm{E}-02$ & $3,69 \mathrm{E}-04$ & $60-100$ & $-1,16 \mathrm{E}-03$ & $-2,06 \mathrm{E}-02$ \\
\hline $16 / 07 / 89$ & 77 & 2 & 140 & $-236,97$ & $-96,97$ & $1,18 \mathrm{E}-01$ & $1,99 \mathrm{E}-02$ & $100-140$ & $-1,47 \mathrm{E}-02$ & $-1,24 \mathrm{E}-01$ \\
\hline $16 / 07 / 89$ & 77 & 2 & 180 & $-238,65$ & $-58,65$ & $2,36 \mathrm{E}-01$ & $6,71 \mathrm{E}-01$ & $140-180$ & $2,82 \mathrm{E}-(1) 2$ & $1,19 \mathrm{E}-01$ \\
\hline $16 / 07 / 89$ & 77 & 2 & 220 & $.244,95$ & $-24,95$ & $3,12 \mathrm{E}-01$ & $2,59 E+00$ & $180-220$ & $4,08 \mathrm{E}-01$ & $1,30 \mathrm{E}+00$ \\
\hline $18 / 07 / 89$ & 79 & 2 & 20 & $-319,30$ & $-299,30$ & $4,37 \mathrm{E}-02$ & $3,65 \mathrm{E}-05$ & & & \\
\hline $18 / 07 / 89$ & 79 & 2 & 60 & $-400,77$ & $-340,77$ & $3,58 \mathrm{E}-02$ & $1,04 \mathrm{E}-05$ & $20-60$ & $2,11 \mathrm{E}-05$ & $5,89 \mathrm{E}-04$ \\
\hline $18 / 07 / 89$ & 79 & 2 & 100 & $-270,57$ & $-170,57$ & $5,56 \mathrm{E}-02$ & $3,19 \mathrm{E}-04$ & $60-100$ & $-1,04 \mathrm{E}-03$ & $-1,87 \mathrm{E}-02$ \\
\hline $18 / 07 / 89$ & 79 & 2 & 140 & $-241,17$ & $-101,17$ & $1,14 \mathrm{E}-01$ & $1,62 \mathrm{E}-02$ & $100-140$ & $-1,19 \mathrm{E}-02$ & $-1,04 \mathrm{E}-01$ \\
\hline $18 / 07 / 89$ & 79 & 2 & 180 & $-238,65$ & $-58,65$ & $2,36 \mathrm{E}-01$ & $6,71 \mathrm{E}-01$ & $140-180$ & $-4,23 \mathrm{E}-02$ & $-1,79 \mathrm{E}-01$ \\
\hline $18 / 07 / 89$ & 79 & 2 & 220 & $-232,35$ & $-12,35$ & $3,79 \mathrm{E}-01$ & $8,96 \mathrm{E}+00$ & $180-220$ & $-1,41 \mathrm{E}+00$ & $-3,72 \mathrm{E}+00$ \\
\hline $21 / 07 / 89$ & 82 & 2 & 20 & & $-299,30$ & $4,37 \mathrm{E}-02$ & $3,65 \mathrm{E}-05$ & & & \\
\hline $21 / 07 / 89$ & 82 & 2 & 60 & & 57 & $3,60 \mathrm{E}-02$ & $1,12 \mathrm{E}-05$ & $20-60$ & $2,16 \mathrm{E}_{-}-05$ & $5,98 \mathrm{E}-04$ \\
\hline $21 / 07 / 89$ & 82 & 2 & 100 & $-266,37$ & $-166,37$ & $5,65 \mathrm{E}-02$ & $3,69 \mathrm{E}-04$ & $60-100$ & $-1,20 \mathrm{E}-03$ & E-02 \\
\hline $21 / 07 / 89$ & 82 & 2 & 140 & $-241,17$ & $-101,17$ & $1,14 \mathrm{E}-01$ & $1,62 \mathrm{E}-02$ & $100-140$ & $-1,02 \mathrm{E}-02$ & $\mathrm{E}-02$ \\
\hline $21 / 07 / 89$ & 82 & 2 & 180 & $-238,65$ & $-58,65$ & $2,36 \mathrm{E}-01$ & $6,71 \mathrm{E}-01$ & $140-$ & $E-02$ & E-01 \\
\hline $21 / 07 / 89$ & 82 & 2 & 220 & -238 & -18 & $3,47 \mathrm{E}-0 \mathrm{I}$ & $4,88 \mathrm{E}+00$ & 180 & $0 \mathrm{E}+00$ & $0,00 \mathrm{E}+00$ \\
\hline & 86 & 2 & 20 & -29 & $-274,10$ & $4,59 \mathrm{E}-02$ & $5,89 \mathrm{E}-0 \mathrm{~S}$ & & & \\
\hline & 86 & 2 & 60 & $-388,17$ & $-328,17$ & $3,64 \mathrm{E}-02$ & $1,30 \mathrm{E}-05$ & $20-60$ & $3,05 \mathrm{E}-05$ & $8,37 E-04$ \\
\hline $25 / 07 / 89$ & 86 & 2 & 100 & $-266,37$ & $-166,37$ & $5,65 \mathrm{E}-02$ & $3,69 \mathrm{E}-04$ & $60-100$ & -03 & \\
\hline $25 / 07 / 89$ & 86 & 2 & 140 & $-241,17$ & $-101,17$ & $1,14 \mathrm{E}_{-} 01$ & $1,62 \mathrm{E}-02$ & 100 & -02 & -02 \\
\hline $25 / 07 / 89$ & 86 & 2 & 180 & $-238,65$ & $-58,65$ & $2,36 \mathrm{E}-01$ & $6,71 \mathrm{E}-01$ & 140 & $-4,23 \mathrm{E}-02$ & $-1,79 \mathrm{E}-01$ \\
\hline $25 / 07 / 89$ & 86 & 2 & 220 & & $-6,05$ & $4,01 \mathrm{E}-01$ & $1,52 \mathrm{E}+01$ & 180 & $-4,78 \mathrm{E}+00$ & $-1,19 E+01$ \\
\hline & 88 & 2 & 20 & $-294,10$ & $-274,10$ & $4,59 \mathrm{E}-02$ & $5,89 \mathrm{E}-05$ & & & \\
\hline $27 / 07 / 89$ & 88 & 2 & 60 & $-388,17$ & $-328,17$ & $3,64 \mathrm{E}-02$ & $1,30 \mathrm{E}-05$ & $20-60$ & $3,05 \mathrm{E}-05$ & $8,37 \mathrm{E}-04$ \\
\hline $27 / 07 / 89$ & 88 & 2 & 100 & $-270,57$ & $-170,57$ & $5,56 \mathrm{E}-02$ & $3,19 \mathrm{E}-04$ & $60-100$ & $\mathrm{E}-04$ & $E-02$ \\
\hline $27 / 07 / 89$ & 88 & 2 & 140 & -24 & $-101,17$ & $1,14 \mathrm{E}-01$ & $1,62 \mathrm{E}-02$ & 100 & $\mathrm{E}-02$ & $4 \mathrm{E}-01$ \\
\hline $07 / 89$ & 88 & 2 & 180 & -23 & $-52,35$ & $2,52 \mathrm{E}-01$ & $9,71 \mathrm{E}-01$ & 140 & $4 \mathrm{E}-01$ & $9 \mathrm{E}-01$ \\
\hline & 88 & 2 & 220 & $-232,35$ & $-12,35$ & $3,79 \mathrm{E}-01$ & $8,96 \mathrm{E}+00$ & & $0,00 \mathrm{E}+00$ & $0,00 \mathrm{E}+00$ \\
\hline $107 / 89$ & 90 & 2 & 20 & -306 & -286 & $4,48 \mathrm{E}-02$ & $4,61 E-05$ & & & \\
\hline $29 / 07 / 89$ & 90 & 2 & 60 & $-388,17$ & -328.17 & $3,64 \mathrm{E}-02$ & $1,30 \mathrm{E}-05$ & & & 3.04 \\
\hline $29 / 07 / 89$ & 90 & 2 & 100 & $-270,57$ & $-170,57$ & $5,56 \mathrm{E}-02$ & $3,19 \mathrm{E}-04$ & 60 & $-9,391$ & $\mathrm{E}-02$ \\
\hline $29 / 07 / 89$ & 90 & 2 & 140 & -24 & -109.57 & $1,07 \mathrm{E}-01$ & $1,09 \mathrm{E}-02$ & 100 & $-5,70 \mathrm{~B}$ & $-5,35 \mathrm{E}-02$ \\
\hline $29 / 07 / 89$ & 90 & 2 & 180 & $-232,35$ & $.52,35$ & $2,52 \mathrm{E}-01$ & $9,71 \mathrm{E}-01$ & & $\mathrm{E}-01$ & $6 \mathrm{E}+00$ \\
\hline $29 / 07 / 89$ & 90 & 2 & 220 & .232 & $-12,35$ & $3,79 \mathrm{E}-0 \mathrm{I}$ & $8,96 \mathrm{E}+00$ & $180-220$ & $0,00 \mathrm{E}+00$ & $0,00 \mathrm{E}+00$ \\
\hline $03 / 05 / 89$ & 3 & 3 & 20 & -159 & -139 & $7,53 \mathrm{E}-02$ & $2,28 \mathrm{E}-03$ & & & \\
\hline $03 / 05 / 89$ & 3 & 3 & 60 & $-231,27$ & $-171,27$ & $5,40 \mathrm{E}-02$ & $5,96 \mathrm{E}-04$ & & & \\
\hline $03 / 05 / 89$ & 3 & 3 & 100 & $-201,87$ & $-101,87$ & $8,32 \mathrm{E}-02$ & $6,07 \mathrm{E}$ & $60-100$ & $-4,46 \mathrm{E}-03$ & $-5,36 \mathrm{E}-02$ \\
\hline $03 / 05 / 89$ & 3 & 3 & 140 &, 67 & -57 & $1,84 \mathrm{E}-01$ & $2,26 \mathrm{E}-01$ & $100-$ & $-2,38 \mathrm{E}-02$ & $-1,29 \mathrm{E}-01$ \\
\hline $03 / 05 / 89$ & 3 & 3 & 180 & $-193,47$ & -13 & $3,68 \mathrm{E}-01$ & $1,14 \mathrm{E}+01$ & 140.180 & $-1,20 \mathrm{E}+00$ & $-3,25 \mathrm{E}+00$ \\
\hline $03 / 05 / 89$ & 3 & 3 & 220 & $-197,67$ & 22,33 & $3,27 \mathrm{E}-01$ & $3,37 \mathrm{E}+00$ & $180-220$ & $3,54 \mathrm{E}-01$ & $1,08 \mathrm{E}+00$ \\
\hline $05 / 05 / 89$ & 5 & 3 & 20 & $-86,70$ & $-66,70$ & $1,51 \mathrm{E}-01$ & $9,87 \mathrm{E}$ & & & \\
\hline $05 / 05 / 89$ & 5 & 3 & 60 & $-215,85$ & $-155,85$ & $5,83 \mathrm{E}-02$ & $1,03 \mathrm{E}-03$ & 20. & $E-03$ & $5,72 \mathrm{E}-02$ \\
\hline $05 / 05 / 89$ & 5 & 3 & 100 & $-189,27$ & $-89,27$ & $9,41 \mathrm{E}-02$ & $1,27 \mathrm{E}-02$ & $60-100$ & $-8,43 \mathrm{E}-03$ & $-8,96 \mathrm{E}-02$ \\
\hline $5 / 89$ & 5 & 3 & 140 & $-180,87$ & $-40,87$ & $2,40 \mathrm{E}-01$ & $8,96 \mathrm{E}-01$ & $100-140$ & $-1,88 \mathrm{E}-01$ & $-7,83 \mathrm{E}-01$ \\
\hline $05 / 05 / 89$ & 5 & 3 & 180 & $-180,87$ & $-0,87$ & $3,83 \mathrm{E}-01$ & $2,11 \mathrm{E}+01$ & $140-180$ & $0,00 \mathrm{E}+00$ & $0,00 E+00$ \\
\hline $05 / 05 / 89$ & 5 & 3 & 220 & $-182,97$ & 37,03 & $2,53 \mathrm{E}-01$ & $8,01 \mathrm{E}-01$ & $180-220$ & $4,21 \mathrm{E}-02$ & $1,67 \mathrm{E}_{-} 01$ \\
\hline $08 / 05 / 89$ & 8 & 3 & 20 & $-86,70$ & $-66,70$ & $1,51 \mathrm{E}-01$ & $9,87 \mathrm{E}-02$ & & & \\
\hline $08 / 05 / 89$ & 8 & 3 & 60 & $-215,85$ & $-155,85$ & $5,83 \mathrm{E}-02$ & $1,03 \mathrm{E}-03$ & $20-60$ & & $5,72 \mathrm{E}-02$ \\
\hline $08 / 05 / 89$ & 8 & 3 & 100 & $-189,27$ & $-89,27$ & $9,41 \mathrm{E}-02$ & $1,27 \mathrm{E}-02$ & $60-100$ & $-8,43 \mathrm{E}-03$ & $-8,96 \mathrm{E}-02$ \\
\hline $08 / 05 / 89$ & 8 & 3 & 140 & $-180,87$ & $-40,87$ & $2,40 \mathrm{E}-01$ & $8,96 \mathrm{E}-01$ & $100-140$ & $-1,88 \mathrm{E}-01$ & $-7,83 \mathrm{E}-01$ \\
\hline $08 / 05 / 89$ & 8 & 3 & 180 & $-180,87$ & $-0,87$ & $3,83 \mathrm{E}-01$ & $2,11 \mathrm{E}+01$ & $140-180$ & $0,00 \mathrm{E}+00$ & $0,00 \mathrm{E}+00$ \\
\hline $08 / 05 / 89$ & 8 & 3 & 220 & -182.97 & 37.03 & $2.53 \mathrm{E}-01$ & $8.01 \mathrm{E}-01$ & $180-220$ & $4,21 E_{-} 02$ & $1,67 \mathrm{E}-01$ \\
\hline $10 / 05 / 89$ & 10 & 3 & 20 & $-89,85$ & $-69,85$ & $1.45 \mathrm{E}-01$ & $7,90 \mathrm{E}-02$ & & & \\
\hline $10 / 05 / 89$ & 10 & 3 & 60 & -201.87 & $-141,87$ & $6.33 \mathrm{E}-02$ & $1.78 \mathrm{E}-03$ & $20-60$ & $5,00 \mathrm{E}-03$ & $7,90 \mathrm{E}-02$ \\
\hline $10 / 05 / 89$ & 10 & 3 & 100 & $-182,97$ & $-82,97$ & $1,01 \mathrm{E}-01$ & $1,90 \mathrm{E}-02$ & $60-100$ & $-8,98 \mathrm{E}-03$ & $-8,89 \mathrm{E}-02$ \\
\hline $10 / 05 / 89$ & 10 & 3 & 140 & $-182,97$ & -42.97 & $2,32 \mathrm{E}-01$ & $7,45 \mathrm{E}-01$ & $100-140$ & $0,00 \mathrm{E}+00$ & $0,00 \mathrm{E}+00$ \\
\hline $10 / 05 / 89$ & 10 & 3 & 180 & $-180,87$ & $-0,87$ & $3.83 \mathrm{E}-01$ & $2,11 E+01$ & $140-180$ & $-1,11 \mathrm{E}+00$ & $-2,89 E+00$ \\
\hline $10 / 05 / 89$ & 10 & 3 & 220 & $-178,77$ & 41,23 & $2.35 \mathrm{E}-01$ & $5,49 \mathrm{E}-01$ & $180-220$ & $-2,88 \mathrm{E}-02$ & $-1,22 \mathrm{E}-01$ \\
\hline
\end{tabular}


Tabela 1 (continuação)

\begin{tabular}{|c|c|c|c|c|c|c|c|c|c|c|}
\hline DATA & DIA & AREA & $\begin{array}{c}\text { PROF } \\
\mathrm{cm}\end{array}$ & $\begin{array}{c}\text { POT. HIDR } \\
\mathrm{cm}\end{array}$ & $\begin{array}{c}\text { POT, MAT } \\
\mathrm{cm}\end{array}$ & $\begin{array}{c}\theta \\
\mathrm{cm}^{3} / \mathrm{cm}^{3}\end{array}$ & $\begin{array}{c}\mathrm{K}(\theta) \\
\mathrm{cm} / \mathrm{dia}\end{array}$ & CAMADA & $\underset{\mathrm{cm} / \mathrm{dia}}{\mathrm{q}}$ & $\begin{array}{c}v \\
\mathrm{~cm} / \mathrm{dia}\end{array}$ \\
\hline $12 / 05 / 89$ & 12 & 3 & 20 & 108,75 & $\begin{array}{r}-88,75 \\
\end{array}$ & $1,14 \mathrm{E}-01$ & $2,39 \mathrm{E}-02$ & & & \\
\hline $12 / 05 / 89$ & 12 & 3 & 60 & $-187,17$ & $-127,17$ & $7,00 \mathrm{E}-02$ & $3,36 \mathrm{E}-03$ & $20-60$ & $6,58 \mathrm{E}-03$ & $9,41 \mathrm{E}-02$ \\
\hline $12 / 05 / 89$ & 12 & 3 & 100 & $-155,67$ & $-55,67$ & $1,51 \mathrm{E}-01$ & $1,55 \mathrm{E}-01$ & $60-100$ & $-1,22 \mathrm{E}-01$ & $-8,12 \mathrm{E}-01$ \\
\hline $12 / 05 / 89$ & 12 & 3 & 140 & $-191,37$ & $-51,37$ & $2,02 \mathrm{E}-01$ & $3,69 \mathrm{E}-01$ & $100 \cdot 140$ & $3,29 \mathrm{E}-0 \mathrm{I}$ & $1,63 E+00$ \\
\hline $12 / 05 / 89$ & 12 & 3 & 180 & $-193,47$ & $-13,47$ & $3,68 \mathrm{E}-01$ & $1,14 \mathrm{E}+01$ & $140-180$ & $5,98 \mathrm{E}-01$ & $1,62 \mathrm{E}+00$ \\
\hline $12 / 05 / 89$ & 12 & 3 & 220 & $-185,07$ & 34,93 & $2,62 E-01$ & $9,74 \mathrm{E}-01$ & $180-220$ & $-2,05 \mathrm{E}-01$ & $-7,81 \mathrm{E}-01$ \\
\hline $15 / 05 / 89$ & 15 & 3 & 20 & $-121,35$ & $-101,35$ & $1,01 \mathrm{E}-01$ & $1,21 \mathrm{E}-02$ & & & \\
\hline $15 / 05 / 89$ & 15 & 3 & 60 & $-170,37$ & $-110,37$ & $8,03 \mathrm{E}-02$ & $7,56 \mathrm{E}-03$ & $20-60$ & $9,26 \mathrm{E}-03$ & $1,15 \mathrm{E}-01$ \\
\hline $15 / 05 / 89$ & 15 & 3 & 100 & $-164,70$ & $-64,70$ & $1,29 \mathrm{E}-01$ & $7,21 \mathrm{E}-02$ & $60-100$ & $-1,02 \mathrm{E}-02$ & $-7,90 \mathrm{E}-02$ \\
\hline $15 / 05 / 89$ & 15 & 3 & 140 & $-191,37$ & $-51,37$ & $2,02 \mathrm{E}-01$ & $3,69 \mathrm{E}-01$ & $100 * 140$ & $2,46 \mathrm{E}-01$ & $1,22 \mathrm{E}+\infty$ \\
\hline $15 / 05 / 89$ & 15 & 3 & 180 & $-193,47$ & & $3,68 \mathrm{E}-01$ & $1,14 \mathrm{E}+01$ & & $5,98 \mathrm{E}-01$ & $1,62 \mathrm{E}+00$ \\
\hline $15 / 05 / 89$ & 15 & 3 & 220 & $-185,07$ & & $2,62 \mathrm{E}-01$ & $9,74 \mathrm{E}-01$ & & $\mathrm{E}-01$ & $E-01$ \\
\hline $17 / 05 / 89$ & 17 & 3 & 20 & $-140,25$ & $-120,25$ & $8,58 \mathrm{E}-02$ & $4,94 \mathrm{E}-03$ & & & \\
\hline $17 / 05 / 89$ & 17 & 3 & 60 & $-174,57$ & $-114,57$ & $7,74 \mathrm{E}-02$ & $6,11 \mathrm{E}-03$ & $20-60$ & $5,24 \mathrm{E}-03$ & $6,77 \mathrm{E}-02$ \\
\hline $17 / 05 / 89$ & 17 & 3 & 100 & $-171,00$ & $-71,00$ & $1,18 \mathrm{E}-01$ & $4,42 \mathrm{E}-02$ & $60-$ & $\mathrm{E}-03$ & \\
\hline & 17 & 3 & 140 & 9,27 & & $2,09 \mathrm{E}-01$ & $4,38 \mathrm{E}-01$ & & 01 & $E-01$ \\
\hline $17 / 05 / 89$ & 17 & 3 & 180 & $-191,37$ & & $3,72 \mathrm{E}-01$ & $1,28 \mathrm{E}+01$ & & -01 & $2+00$ \\
\hline $17 / 05 / 89$ & 17 & 3 & 220 & $-185,07$ & & $2,62 \mathrm{E}-01$ & $9,74 \mathrm{E}-01$ & & $8-01$ & $\mathrm{E}-01$ \\
\hline $19 / 05 / 89$ & 19 & 3 & 20 & $-168,60$ & $-148,60$ & $7,12 \mathrm{E}-02$ & $1,61 \mathrm{E}-03$ & & & \\
\hline $19 / 05 / 89$ & 19 & 3 & 60 & 7,17 & $-127,17$ & $7,00 \mathrm{E}-02$ & $3,36 \mathrm{E}-03$ & $20-60$ & $1,56 \mathrm{E}-03$ & $2,23 \mathrm{E}-02$ \\
\hline & 19 & 3 & 100 & & & 301 & $5,62 \mathrm{E}-02$ & & $\mathrm{E}-02$ & $E-01$ \\
\hline $19 / 05 / 89$ & 19 & 3 & 140 & $-195,57$ & & & $2,65 \mathrm{E}-01$ & & $\mathrm{E}-01$ & $E-01$ \\
\hline $19 / 05 / 89$ & 19 & 3 & 180 & $-199,77$ & & $3,52 \mathrm{E}-01$ & $7,80 \mathrm{E}+00$ & & & $2,32 \mathrm{E}+00$ \\
\hline $19 / 05 / 89$ & 19 & 3 & 220 & $-203,25$ & 16,75 & $3,57 \mathrm{E}-01$ & $5,89 \mathrm{E}+00$ & & & $1,43 \mathrm{E}+00$ \\
\hline & 22 & 3 & 20 & 3,05 & & $6,76 \mathrm{E}-02$ & $1,15 \mathrm{E}-03$ & & & \\
\hline & 22 & 3 & 60 & & & $6,69 \mathrm{E}-02$ & $2,54 \mathrm{E}-03$ & & & -02 \\
\hline $22 / 05 / 89$ & 22 & 3 & 100 & & & $2-01$ & $5,62 \mathrm{E}-02$ & & $E-02$ & $\mathrm{E}-01$ \\
\hline $22 / 05 / 89$ & 22 & 3 & 140 & & & $1,96 \mathrm{E}-01$ & $3,13 E-01$ & & & $E+\infty$ \\
\hline $22 / 05 / 89$ & 22 & 3 & 180 & $-193,47$ & & $3,68 \mathrm{E}-01$ & $1,14 \mathrm{E}+01$ & & $+\infty$ & $E+\infty$ \\
\hline & 22 & 3 & 220 &, 40 & & -01 & $7,98 \mathrm{E}+00$ & & & $6,91 \mathrm{E}+00$ \\
\hline & 24 & 3 & 20 & & & & $5,78 \mathrm{E}-04$ & & & \\
\hline $24 / 05 / 89$ & 24 & 3 & 60 & & & & $3,70 \mathrm{E}-03$ & & E-03 & $\mathrm{E}-02$ \\
\hline $24 / 05 / 89$ & 24 & 3 & 100 & & & & $8,37 \mathrm{E}-03$ & & & -02 \\
\hline $24 / 05 / 89$ & 24 & 3 & 140 & 3,97 & -63 & $1,69 \mathrm{E}-01$ & $1,43 \mathrm{E}-0 \mathrm{I}$ & & -02 & 01 \\
\hline & 24 & 3 & 180 & 10 & & 01 & $7,64 \mathrm{E}+00$ & & $E-01$ & $E+\infty$ \\
\hline & 24 & 3 & 220 & & & -01 & $7,98 \mathrm{E}+00$ & & +00 & +00 \\
\hline $26 / 05 / 89$ & 26 & 3 & 20 & 90 & & & $4,68 \mathrm{E}-04$ & & & \\
\hline $26 / 05 / 89$ & 26 & 3 & 60 & 5,97 & & & $3,68 \mathrm{E}-04$ & & & -03 \\
\hline $26 / 05 / 89$ & 26 & 3 & 100 & $-180,45$ & & $1,04 \mathrm{E}-01$ & $2,25 \mathrm{E}-02$ & & & 2.01 \\
\hline $26 / 05 / 89$ & 26 & 3 & 140 & 17 & & $1,60 \mathrm{E}-01$ & $1,07 \mathrm{E}-01$ & & $E-02$ & -01 \\
\hline $26 / 05 / 89$ & 26 & 3 & 180 &, 07 & & & $5,21 \mathrm{E}+00$ & & $\mathrm{E}-01$ & 201 \\
\hline $26 / 05 / 89$ & 26 & 3 & 220 & 6,40 & 3,60 & $3,73 \mathrm{E}-01$ & $7,98 \mathrm{E}+00$ & $180-220$ & $6,58 \mathrm{E}-02$ & $1,76 \mathrm{E}-0 \mathrm{I}$ \\
\hline $29 / 05 / 89$ & 29 & 3 & 20 & 66,90 & & $5,93 \mathrm{E}-02$ & $4,68 \mathrm{E}-04$ & & & \\
\hline $29 / 05 / 89$ & 29 & 3 & 60 & $-241,77$ & & $5,16 \mathrm{E}-02$ & $4,21 \mathrm{E}_{-} 04$ & & & \\
\hline $29 / 05 / 89$ & 29 & 3 & 100 & 7,30 & -77 & $1,08 \mathrm{E}-01$ & $2,80 \mathrm{E}-02$ & & 02 & -01 \\
\hline & 29 & 3 & 140 & & & & $1,07 \mathrm{E}-01$ & & & E-01 \\
\hline $29 / 05 / 89$ & 29 & 3 & 180 & & & & $5,21 \mathrm{E}+00$ & $140-180$ & $4 \mathrm{E}-01$ & $1 \mathrm{E}-01$ \\
\hline $29 / 05 / 89$ & 29 & 3 & 220 & $-206,40$ & & $3,73 \mathrm{E}-01$ & $7,98 \mathrm{E}+00$ & $180-220$ & $6,58 \mathrm{E}-02$ & $1,76 \mathrm{E}-01$ \\
\hline $31 / 05 / 89$ & 31 & 3 & 20 & 9,50 & $-199,50$ & $5,65 \mathrm{E}-02$ & $3,29 \mathrm{E}-04$ & & & \\
\hline $31 / 05 / 89$ & 31 & 3 & 60 & $-245,97$ & $-185,97$ & $5,07 \mathrm{E}-02$ & $3,68 \mathrm{E}-04$ & & & $4,80 \mathrm{E}-03$ \\
\hline & 31 & 3 & 100 & & & & $2,80 \mathrm{E}-02$ & & $-4,80 \mathrm{E}-02$ & $3 \mathrm{E}-01$ \\
\hline $5 / 89$ & 31 & 3 & 140 & & & $1,56 \mathrm{E}-01$ & $9,33 \mathrm{E}-02$ & $100-140$ & $7,69 \mathrm{E}-02$ & $4 \mathrm{E}-01$ \\
\hline & 31 & 3 & 180 & & $-28,17$ & $3,27 \mathrm{E}-0 \mathrm{I}$ & $4,54 \mathrm{E}+00$ & $140-180$ & $-2,39 \mathrm{E}-01$ & $-7,31 \mathrm{E}-01$ \\
\hline $31 / 05 / 89$ & 31 & 3 & 220 & $-212,70$ & 7,30 & $3,98 \mathrm{E}-0 \mathrm{I}$ & $1,38 \mathrm{E}+01$ & $180-220$ & $1,56 \mathrm{E}+00$ & $3,93 \mathrm{E}+00$ \\
\hline $02 / 06 / 89$ & 33 & 3 & 20 & $-213,20$ & $-193,20$ & $5,78 \mathrm{E}-02$ & $3,92 \mathrm{E}-04$ & & & \\
\hline $02 / 06 / 89$ & 33 & 3 & 60 & $-243,87$ & $-183,87$ & $5,11 \mathrm{E}-02$ & $3,93 \mathrm{E}-04$ & & $3,02 \mathrm{E}-04$ & $5,90 \mathrm{E}-03$ \\
\hline $02 / 06 / 89$ & 33 & 3 & 100 & & & & $2,80 \mathrm{E}-02$ & & $-4,65 \mathrm{E}-02$ & $-4,30 \mathrm{E}-01$ \\
\hline $02 / 06 / 89$ & 33 & 3 & 140 & $-208,17$ & $-68,17$ & $1,60 \mathrm{E}-01$ & $1,07 \mathrm{E}-01$ & $100-140$ & $8,28 \mathrm{E}-02$ & $5,18 \mathrm{E}-01$ \\
\hline $02 / 06 / 89$ & 33 & 3 & 180 & $-206,07$ & $-26,07$ & $3,33 \mathrm{E}-01$ & $5,21 \mathrm{E}+00$ & $140-180$ & $-2,74 \mathrm{E}-01$ & $-8,21 \mathrm{E}-01$ \\
\hline $02 / 06 / 89$ & 33 & 3 & 220 & $-203,25$ & 16,75 & $3,57 \mathrm{E}-01$ & $5,89 \mathrm{E}+00$ & $180-220$ & $-4,15 \mathrm{E}-01$ & $-1,16 \mathrm{E}+00$ \\
\hline
\end{tabular}


Tabela 1 (continuação)

\begin{tabular}{|c|c|c|c|c|c|c|c|c|c|c|}
\hline DATA & DIA & ÁREA & $\begin{array}{c}\text { PROF } \\
\mathrm{cm}\end{array}$ & $\begin{array}{c}\text { POT. HIDR } \\
\mathrm{cm}\end{array}$ & $\begin{array}{c}\text { POT.MAT } \\
\mathrm{cm}\end{array}$ & {$\left[\begin{array}{c}\theta \\
\mathrm{cm}^{3} / \mathrm{cm}^{3}\end{array}\right.$} & $\begin{array}{c}\mathrm{K}(\theta) \\
\mathrm{cm} / \mathrm{dia}\end{array}$ & CAMADA & $\begin{array}{c}\mathbf{q} \\
\mathrm{cm} / \mathrm{dia} \\
\end{array}$ & $\begin{array}{c}v \\
\mathrm{~cm} / \mathrm{dia}\end{array}$ \\
\hline $05 / 06 / 89$ & 36 & 3 & 20 & $-206,90$ & $-186,90$ & $5,93 \mathrm{E}-02$ & $4,68 \mathrm{E}-04$ & & & \\
\hline $05 / 06 / 89$ & 36 & 3 & 60 & $-250,17$ & $-190,17$ & $4,99 \mathrm{E}-02$ & $3,23 \mathrm{E}-04$ & 20.60 & $3,49 \mathrm{E}-04$ & $7,00 \mathrm{E}-03$ \\
\hline $05 / 06 / 89$ & 36 & 3 & 100 & $-177,30$ & $.77,30$ & $1,08 \mathrm{E}-01$ & $2,80 \mathrm{E}-02$ & $60-100$ & $-5,09 \mathrm{E}-02$ & $-4,70 \mathrm{E}-01$ \\
\hline $05 / 06 / 89$ & 36 & 3 & 140 & $-201,87$ & $-61,87$ & $1,74 \mathrm{E}-01$ & $1,66 \mathrm{E}-01$ & $100-140$ & $1,02 \mathrm{E}-01$ & $5,88 \mathrm{E}-01$ \\
\hline $05 / 06 / 89$ & 36 & 3 & 180 & $-199,77$ & $-19,77$ & $3,52 \mathrm{E}-01$ & $7,80 \mathrm{E}+00$ & $140-180$ & $-4,09 \mathrm{E}-01$ & $-1,16 \mathrm{E}+00$ \\
\hline $05 / 06 / 89$ & 36 & 3 & 220 & $-203,25$ & 16,75 & $3,57 \mathrm{E}-01$ & $5,89 E+00$ & $180-220$ & $5,13 E-01$ & $1,43 \mathrm{E}+00$ \\
\hline $07 / 06 / 89$ & 38 & 3 & 20 & $-232,10$ & $-212,10$ & $5,41 \mathrm{E}-02$ & $2,37 \mathrm{E}-04$ & & & \\
\hline $07 / 06 / 89$ & 38 & 3 & 60 & $-281,67$ & $-221,67$ & $4,49 \mathrm{E}-02$ & $1,31 \mathrm{E}-04$ & $20-60$ & $1,63 \mathrm{E}-04$ & $3,62 \mathrm{E}-03$ \\
\hline $07 / 06 / 89$ & 38 & 3 & 100 & $-180,45$ & $-80,45$ & $1,04 \mathrm{E}-01$ & $2,25 \mathrm{E}-02$ & $60-100$ & $-5,69 \mathrm{E}-02$ & $-5,47 \mathrm{E}-01$ \\
\hline $07 / 06 / 89$ & 38 & 3 & 140 & $-202,50$ & $-62,50$ & $1,72 \mathrm{E}-01$ & $1,59 \mathrm{E}-01$ & $100-140$ & $8,76 \mathrm{E}-02$ & $5,09 \mathrm{E}-01$ \\
\hline $07 / 06 / 89$ & 38 & 3 & 180 & $-203,97$ & $-23,97$ & $3,40 \mathrm{E}-01$ & $5,97 \mathrm{E}+00$ & $140-180$ & $2,19 \mathrm{E}-01$ & $6,46 \mathrm{E}-01$ \\
\hline $07 / 06 / 89$ & 38 & 3 & 220 & $-206,40$ & 13,60 & $3,73 \mathrm{E}-01$ & $7,98 \mathrm{E}+00$ & $180-220$ & $4,85 \mathrm{E}-01$ & $1,30 \mathrm{E}+00$ \\
\hline $09 / 06 / 89$ & 40 & 3 & 20 & $-232,10$ & $-212,10$ & $5,41 \mathrm{E}-02$ & $2,37 \mathrm{E}-04$ & & & \\
\hline $09 / 06 / 89$ & 40 & 3 & 60 & $-290,07$ & $-230,07$ & $4,39 \mathrm{E}-02$ & $1,05 \mathrm{E}-04$ & $20-60$ & $1,53 \mathrm{E}-04$ & $3,48 \mathrm{E}-03$ \\
\hline $09 / 06 / 89$ & 40 & 3 & 100 & $-183,60$ & $-83,60$ & $1,00 \mathrm{E}-01$ & $1,82 \mathrm{E}-02$ & $60-100$ & $-4,85 \mathrm{E}-02$ & $-4,84 \mathrm{E}-01$ \\
\hline $09 / 06 / 89$ & 40 & 3 & 140 & $-202,50$ & $-62,50$ & $1,72 \mathrm{E}-01$ & $1,59 \mathrm{E}-01$ & $100-140$ & $7,51 \mathrm{E}-02$ & $4,36 \mathrm{E}-01$ \\
\hline $09 / 06 / 89$ & 40 & 3 & 180 & $-203,97$ & $-23,97$ & $3,40 \mathrm{E}-01$ & $5,97 \mathrm{E}+00$ & $140-180$ & $2,19 \mathrm{E}-01$ & $6,46 \mathrm{E}-01$ \\
\hline $09 / 06 / 89$ & 40 & 3 & 220 & $-209,55$ & 10,45 & $3,87 \mathrm{E}-01$ & $1,06 \mathrm{E}+01$ & $180-220$ & $1,48 E+00$ & $3,83 \mathrm{E}+\infty$ \\
\hline $12 / 06 / 89$ & 43 & 3 & 20 & $-219,50$ & $-199,50$ & $5,65 \mathrm{E}-02$ & $3,29 \mathrm{E}-04$ & & & \\
\hline $12 / 06 / 89$ & 43 & 3 & 60 & $-302,67$ & $-242,67$ & $4,25 \mathrm{E}-02$ & $7,70 \mathrm{E}-05$ & $20-60$ & $1,60 \mathrm{E}-04$ & $3,77 \mathrm{E}-03$ \\
\hline $12 / 06 / 89$ & 43 & 3 & 100 & $-177,30$ & $-77,30$ & $1,08 \mathrm{E}-01$ & $2,80 \mathrm{E}-02$ & $60-100$ & $-8,76 \mathrm{E}-02$ & $-8,09 \mathrm{E}-01$ \\
\hline $12 / 06 / 89$ & 43 & 3 & 140 & $-199,35$ & $-59,35$ & $1,80 \mathrm{E}-01$ & $2,00 \mathrm{E}-01$ & $100-140$ & $1,10 \mathrm{E}-01$ & $6,12 \mathrm{E}-01$ \\
\hline $12 / 06 / 89$ & 43 & 3 & 180 & $-206,07$ & $-26,07$ & $3,33 \mathrm{E}-01$ & $5,21 \mathrm{E}+00$ & $140-180$ & $8,76 \mathrm{E}-01$ & $2,63 \mathrm{E}+00$ \\
\hline $12 / 06 / 89$ & 43 & 3 & 220 & $-219,00$ & 1,00 & $4,07 \mathrm{E}-01$ & $2,08 \mathrm{E}+01$ & $180-220$ & $6,74 \mathrm{E}+00$ & $1,65 \mathrm{E}+01$ \\
\hline $14 / 06 / 89$ & 45 & 3 & 20 & $-219,50$ & $-199,50$ & $5,65 \mathrm{E}-02$ & $3,29 \mathrm{E}-04$ & & & \\
\hline $14 / 06 / 89$ & 45 & 3 & 60 & $-304,77$ & $-244,77$ & $4,23 \mathrm{E}-02$ & $7,32 \mathrm{E}-05$ & $20-60$ & $1,56 \mathrm{E}-04$ & $3,69 \mathrm{E}-03$ \\
\hline $14 / 06 / 89$ & 45 & 3 & 100 & $-180,45$ & $-80,45$ & $1,04 \mathrm{E}-01$ & $2,25 \mathrm{E}-02$ & $60-100$ & $-6,99 \mathrm{E}-02$ & $-6,72 \mathrm{E}-01$ \\
\hline $14 / 06 / 89$ & 45 & 3 & 140 & $-202,50$ & $-62,50$ & $1,72 \mathrm{E}-01$ & $1,59 \mathrm{E}-01$ & $100-140$ & $8,76 \mathrm{E}-02$ & $5,09 \mathrm{E}-01$ \\
\hline $14 / 06 / 89$ & 45 & 3 & 180 & $-206,07$ & $-26,07$ & $3,33 \mathrm{E}-01$ & $5,21 \mathrm{E}+00$ & $140-180$ & $4,65 \mathrm{E}-01$ & $1,40 \mathrm{E}+00$ \\
\hline $14 / 06 / 89$ & 45 & 3 & 220 & $-206,40$ & 13,60 & $3,73 \mathrm{E}-01$ & $7,98 \mathrm{E}+00$ & $180-220$ & $6,58 \mathrm{E}-02$ & $1,76 \mathrm{E}-01$ \\
\hline $16 / 06 / 89$ & 47 & 3 & 20 & $-232,10$ & $-212,10$ & $5,41 \mathrm{E}-02$ & $2,37 \mathrm{E}-04$ & & & \\
\hline $16 / 06 / 89$ & 47 & 3 & 60 & $-315,27$ & $-255,27$ & $4,12 \mathrm{E}-02$ & $5,71 \mathrm{E}-05$ & $20-60$ & $1,19 \mathrm{E}-04$ & $2,88 \mathrm{E}-03$ \\
\hline $16 / 06 / 89$ & 47 & 3 & 100 & $-167,85$ & $-67,85$ & $1,23 \mathrm{E}-01$ & $5,62 \mathrm{E}-02$ & $60-100$ & $-2,07 \mathrm{E}-01$ & $-1,68 \mathrm{E}+00$ \\
\hline $16 / 06 / 89$ & 47 & 3 & 140 & $-147,27$ & -7.27 & $3,86 \mathrm{E}-01$ & $1,60 \mathrm{E}+01$ & $100-140$ & $-8,22 \mathrm{E}+00$ & $-2,13 \mathrm{E}+01$ \\
\hline $16 / 06 / 89$ & 47 & 3 & 180 & $-212,37$ & $-32,37$ & $3,13 \mathrm{E}-01$ & $3,45 \mathrm{E}+00$ & $140-180$ & $5,62 \mathrm{E}+00$ & $1,80 \mathrm{E}+01$ \\
\hline $16 / 06 / 89$ & 47 & 3 & 220 & $-212,70$ & 7,30 & $3,98 \mathrm{E}-01$ & $1,38 \mathrm{E}+01$ & $180-220$ & $1,14 \mathrm{E}-01$ & $2,86 \mathrm{E}-01$ \\
\hline $19 / 06 / 89$ & 50 & 3 & 20 & $-232,10$ & $-212,10$ & $5,411 \mathrm{E}-02$ & $2,37 \mathrm{E}-04$ & & & \\
\hline $19 / 06 / 89$ & 50 & 3 & 60 & $-319,47$ & $-259,47$ & $4,09 \mathrm{E}-02$ & $5,19 \mathrm{E}-05$ & $20-60$ & $1,13 \mathrm{E}-04$ & $2,77 \mathrm{E}-03$ \\
\hline $19 / 06 / 89$ & 50 & 3 & 100 & $-167,85$ & $-67,85$ & $1,23 \mathrm{E}-01$ & $5,62 \mathrm{E}-02$ & $60-100$ & $-2,13 \mathrm{E}-01$ & $-1,73 \mathrm{E}+00$ \\
\hline $19 / 06 / 89$ & 50 & 3 & 140 & $-211,95$ & $-71,95$ & $1,53 \mathrm{E}-01$ & $8,36 \mathrm{E}-02$ & $100-140$ & $9,22 \mathrm{E}-02$ & $6,04 \mathrm{E}-01$ \\
\hline $19 / 06 / 89$ & 50 & 3 & 180 & $-218,67$ & $-38,67$ & $2,92 \mathrm{E}-01$ & $2,29 \mathrm{E}+00$ & $140-180$ & $3,84 \mathrm{E}-01$ & $1,31 \mathrm{E}+00$ \\
\hline $19 / 06 / 89$ & 50 & 3 & 220 & $-212,70$ & 7,30 & $3,98 \mathrm{E}-01$ & $1,38 \mathrm{E}+01$ & $180-220$ & $-2,06 \mathrm{E}+00$ & $-5,18 \mathrm{E}+00$ \\
\hline $21 / 06 / 89$ & 52 & 3 & 20 & & & & & & & \\
\hline $21 / 06 / 89$ & 52 & 3 & 60 & & & & & $20-60$ & & \\
\hline $21 / 06 / 89$ & 52 & 3 & 100 & $-185,07$ & $-85,07$ & $9,86 \mathrm{E}-02$ & $1,66 \mathrm{E}-02$ & $60-100$ & $7,66 \mathrm{E}-02$ & $7,77 \mathrm{E}-01$ \\
\hline $21 / 06 / 89$ & 52 & 3 & 140 & $-197,67$ & $-57,67$ & $1,84 \mathrm{E}-01$ & $2,26 \mathrm{E}-01$ & $100-140$ & $7,13 \mathrm{E}-02$ & $3,87 \mathrm{E}-01$ \\
\hline $21 / 06 / 89$ & 52 & 3 & 180 & $-206,07$ & $-26,07$ & $3,33 E-01$ & $5,21 \mathrm{E}+00$ & $140-180$ & $1,09 \mathrm{E}+00$ & $3,28 \mathrm{E}+00$ \\
\hline $21 / 06 / 89$ & 52 & 3 & 220 & $-210,27$ & 9,73 & $3,90 \mathrm{E}-01$ & $1,13 \mathrm{E}+01$ & $180-220$ & $1,19 \mathrm{E}+00$ & $3,05 \mathrm{E}+00$ \\
\hline $23 / 06 / 89$ & 54 & 3 & 20 & $-143,40$ & $-123,40$ & $8,38 \mathrm{E}-02$ & $4,31 \mathrm{E}-03$ & & & \\
\hline $23 / 06 / 89$ & 54 & 3 & 60 & $-197,67$ & $-137,67$ & $6,50 \mathrm{E}-02$ & $2,12 \mathrm{E}-03$ & $20-60$ & $2,88 \mathrm{E}-03$ & $4,43 \mathrm{E}-02$ \\
\hline $23 / 06 / 89$ & 54 & 3 & 100 & $-206,07$ & $-106,07$ & $8,03 \mathrm{E}-02$ & $4,84 \mathrm{E}-03$ & $60-100$ & $1,02 \mathrm{E}-03$ & $1,27 \mathrm{E}-02$ \\
\hline $23 / 06 / 89$ & 54 & 3 & 140 & $-201,87$ & $-61,87$ & $1,74 \mathrm{E}-01$ & $1,66 \mathrm{E}-01$ & $100-140$ & $-1,75 \mathrm{E}-02$ & $-1,00 \mathrm{E}-01$ \\
\hline $23 / 06 / 89$ & 54 & 3 & 180 & $-212,70$ & $-32,70$ & $3,12 \mathrm{E}-0 \mathrm{1}$ & $3,38 \mathrm{E}+00$ & $140-180$ & $9,14 E-01$ & $2,93 E+00$ \\
\hline $23 / 06 / 89$ & 54 & 3 & 220 & $-212,70$ & 7,30 & $3,98 \mathrm{E}-01$ & $1,38 \mathrm{E}+01$ & $180-220$ & $0,00 \mathrm{E}+00$ & $0,00 \mathrm{E}+00$ \\
\hline $26 / 06 / 89$ & 57 & 3 & 20 & $-162,30$ & $-142,30$ & $7,38 \mathrm{E}-02$ & $2,02 \mathrm{E}-03$ & & & \\
\hline $26 / 06 / 89$ & 57 & 3 & 60 & $-210,27$ & $-150,27$ & $6,02 \mathrm{E}-02$ & $1,28 \mathrm{E}-03$ & $20-60$ & $1,53 \mathrm{E}-03$ & $2,55 \mathrm{E}-02$ \\
\hline $26 / 06 / 89$ & 57 & 3 & 100 & $-222,87$ & $-122,87$ & $7,08 \mathrm{E}-02$ & $2,10 \mathrm{E}-03$ & $60-100$ & $6,62 \mathrm{E}-04$ & $9,35 \mathrm{E}-03$ \\
\hline $26 / 06 / 89$ & 57 & 3 & 140 & $-218,67$ & $-78,67$ & $1,41 \mathrm{E}-01$ & 5,49E-02 & $100-140$ & $-5,77 \mathrm{E}-03$ & $-4,08 \mathrm{E}-02$ \\
\hline $26 / 06 / 89$ & 57 & 3 & 180 & $-193,47$ & $-13,47$ & $3,68 \mathrm{E}-01$ & $1,14 \mathrm{E}+01$ & $140-180$ & $-7,17 \mathrm{E}+00$ & $-1,95 \mathrm{E}+01$ \\
\hline $26 / 06 / 89$ & 57 & 3 & 220 & $-206,07$ & 13,93 & $3,72 \mathrm{E}-01$ & {$[7,74 \mathrm{E}+00$} & $180-220$ & $2,44 \mathrm{E}+00$ & $6,56 \mathrm{E}+00$ \\
\hline
\end{tabular}


Tabela 1 (continuação)

\begin{tabular}{|c|c|c|c|c|c|c|c|c|c|c|}
\hline DATA & DIA & AREA & $\begin{array}{c}\text { PROF } \\
\mathrm{cm}\end{array}$ & 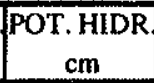 & $\begin{array}{c}\text { POT. MAT } \\
\mathrm{cm}\end{array}$ & $\mid \begin{array}{c}\theta \\
\mathrm{cm}^{3} / \mathrm{cm}^{3}\end{array}$ & $\begin{array}{c}\mathbf{K}(\theta) \\
\mathrm{cm} / \text { dia }\end{array}$ & CAMADA & $\begin{array}{c}\mathbf{q} \\
\mathrm{cm} / \mathrm{dia}\end{array}$ & $\begin{array}{c}v \\
\mathrm{~cm} / \mathrm{dia}\end{array}$ \\
\hline $8 / 06 / 89$ & 59 & 3 & 20 & $-168,60$ & $-148,60$ & $7,12 \mathrm{E}-02$ & $1,61 \mathrm{E}-03$ & & & \\
\hline $28 / 06 / 80$ & 59 & 3 & 60 & $-227,07$ & $-167,07$ & $5,51 \mathrm{E}-02$ & $6,89 \mathrm{E}-04$ & & $1,01 \mathrm{E}-03$ & $1,83 \mathrm{E}-02$ \\
\hline $28 / 06 / 89$ & 59 & 3 & 100 & $-231,27$ & $-131,27$ & $6,71 \mathrm{E}-02$ & $1,44 \mathrm{E}-03$ & & $1,51 \mathrm{E}-04$ & \\
\hline $28 / 06 / 89$ & 59 & 3 & 140 & $-214,47$ & $-74,47$ & $1,48 \mathrm{E}-01$ & $7,12 \mathrm{E}-02$ & & $-2,99 \mathrm{E}-02$ & $-2,02 \mathrm{E}-01$ \\
\hline $28 / 06 / 89$ & 59 & 3 & 180 & $-206,07$ & $-26,07$ & $3,33 \mathrm{E}-01$ & $5,21 \mathrm{E}+00$ & & $-1,09 \mathrm{E}+00$ & $-3,28 E+00$ \\
\hline & 59 & 3 & 220 & $-210,27$ & 9,73 & $3,90 \mathrm{E}-01$ & $1,13 \mathrm{E}+01$ & & $1,19 E+00$ & $E+00$ \\
\hline & 61 & 3 & 20 & $-231,60$ & $-211,60$ & $5,42 \mathrm{E}-02$ & $2,40 \mathrm{E}-04$ & & & \\
\hline $30 / 06 / 89$ & 61 & 3 & 60 & $-260,67$ & $-200,67$ & $4,80 \mathrm{E}-02$ & $2,35 \mathrm{E}-04$ & & $1,71 \mathrm{E}-04$ & $3,57 \mathrm{E}-03$ \\
\hline $30 / 06 / 89$ & 61 & 3 & 100 & $-235,47$ & $-135,47$ & $6.55 \mathrm{E}-02$ & $1,20 \mathrm{E}-03$ & & $-7,58 \mathrm{E}-04$ & $-1,16 \mathrm{E}-02$ \\
\hline $30 / 06 / 89$ & 61 & 3 & 140 & $-218,67$ & $-78,67$ & $1,41 \mathrm{E}-01$ & $5,49 \mathrm{E}-02$ & & $-2,31 \mathrm{E}-02$ & \\
\hline & 61 & 3 & 180 & & & & $3,96 \mathrm{E}+00$ & & & \\
\hline & 61 & 3 & 220 & & & & $1,88 \mathrm{E}+01$ & & +00 & +01 \\
\hline $07 / 89$ & 63 & 3 & 20 & 6,30 & & $\mathrm{E}-02$ & $1,32 \mathrm{E}-04$ & & & \\
\hline & 63 & 3 & 60 & $-294,10$ & & & $9,51 \mathrm{E}-05$ & & & \\
\hline & 63 & 3 & 100 & $-211,95$ & & $\mathrm{E}-02$ & $3,56 \mathrm{E}-03$ & & $E-03$ & \\
\hline & 63 & 3 & 140 & & & -01 & $3,89 \mathrm{E}-02$ & & & \\
\hline & 63 & 3 & 180 & & & & $1,34 \mathrm{E}+00$ & & & \\
\hline & 63 & 3 & 220 & 5,30 & & & $1,60 \mathrm{E}+01$ & & & +00 \\
\hline & 65 & 3 & 20 & & & & $9,73 \mathrm{E}-05$ & & & \\
\hline & 65 & 3 & 60 & 67 & & & $1,31 \mathrm{E}-04$ & & & \\
\hline & 65 & 3 & 100 & & & & $1,94 \mathrm{E}-03$ & & & \\
\hline & 65 & 3 & 140 & & & & $5,63 \mathrm{E}-02$ & & & \\
\hline & 65 & 3 & 180 & & & & $1,02 E+00$ & & & \\
\hline & 65 & 3 & 220 & & & & $1,60 \mathrm{E}+01$ & & +00 & \\
\hline & 68 & 3 & 20 & & & $2-02$ & $1,19 \mathrm{E}-04$ & & & \\
\hline & 68 & 3 & & & & & $2,67 \mathrm{E}-04$ & & & \\
\hline & 68 & 3 & & & & & $4,95 \mathrm{E}-03$ & & & \\
\hline & 68 & 3 & 140 & & & & $3,73 \mathrm{E}-02$ & & & \\
\hline & 68 & 3 & 180 & & & & $3,38 \mathrm{E}+00$ & & & \\
\hline & 68 & 3 & 220 & & & & $9,17 \mathrm{E}+00$ & & & \\
\hline & 71 & 3 & 20 & & & & $9,84 \mathrm{E}-05$ & & & \\
\hline & 71 & 3 & 6 & & & -02 & $6,96 \mathrm{E}-05$ & & & \\
\hline & 71 & 3 & 100 & & & & $2,61 \mathrm{E}-03$ & & & \\
\hline & 71 & 3 & 140 & & & & $2,68 \mathrm{E}-02$ & & & \\
\hline & 71 & 3 & 180 & & & & $1,02 \mathrm{E}+00$ & & & \\
\hline & 71 & 3 & 220 & & & & $2,65 \mathrm{E}+00$ & & & \\
\hline & 73 & 3 & 20 & & & & & & & \\
\hline & 73 & 3 & 60 & & & & & & & \\
\hline & 73 & 3 & & & & & $2,61 \mathrm{E}-03$ & & & \\
\hline & 73 & 3 & 140 & & & & $2,15 \mathrm{E}-02$ & & & \\
\hline & 73 & 3 & & & & & $1,02 \mathrm{E}+00$ & & & \\
\hline & 73 & 3 & 220 & & & & $2,65 \mathrm{E}+00$ & & & \\
\hline & 75 & 3 & & & & & & & & \\
\hline & 75 & 3 & & & & & & & & \\
\hline & 75 & 3 & & & & E-02 & $8,51 \mathrm{E}-04$ & & & \\
\hline $14 / 07 / 89$ & 75 & 3 & 140 & & & & $4,28 \mathrm{E}-02$ & & & \\
\hline & 75 & 3 & & & & & $2,29 \mathrm{E}+00$ & & & \\
\hline & 75 & 3 & 220 & & & & $2,06 \mathrm{E}+01$ & & & \\
\hline & 77 & 3 & & & & & & & & \\
\hline & 77 & 3 & 60 & & & & & & & \\
\hline $16 / 07 / 89$ & 77 & 3 & 100 & & & $7,31 \mathrm{E}-02$ & $2,61 \mathrm{E}-03$ & & & \\
\hline $16 / 07 / 89$ & 77 & 3 & 140 & & & 01 & $2,68 \mathrm{E}-02$ & & & \\
\hline & 77 & 3 & & & & & $1,02 \mathrm{E}+00$ & & & \\
\hline & & 3 & & & & & $2,65 \mathrm{E}+00$ & & & \\
\hline & 79 & 3 & & & & & & & & \\
\hline & 79 & 3 & 60 & & & & & & & \\
\hline & 79 & 3 & 100 & & & $7,00 \mathrm{E}-02$ & $1,94 \mathrm{E}-03$ & & & $-7,76 \mathrm{E}-02$ \\
\hline $18 / 07 / 89$ & 79 & 3 & 140 & $-239,67$ & & $1,15 \mathrm{E}-01$ & $1,74 \mathrm{E}-02$ & & & $5,70 \mathrm{E}-02$ \\
\hline $18 / 07 / 89$ & 79 & 3 & 180 & & & & $1,02 \mathrm{E}+00$ & & & $-8,07 \mathrm{E}-01$ \\
\hline $18 / 07 / 89$ & 79 & 3 & 220 & $-244,70$ & $-24,70$ & $3,14 \mathrm{E}-01$ & $2,65 \mathrm{E}+00$ & $180-220$ & $8,69 \mathrm{E}-01$ & $2,77 E+00$ \\
\hline
\end{tabular}


Tabela 1 (continuação)

\begin{tabular}{|c|c|c|c|c|c|c|c|c|c|c|}
\hline DATA & DIA & AREA & $\begin{array}{c}P R O F \\
\mathrm{~cm}\end{array}$ & $\begin{array}{c}\text { POT. HIDR } \\
\mathrm{cm}\end{array}$ & $\begin{array}{c}\text { POT. MAT } \\
\mathrm{cm}\end{array}$ & $\begin{array}{c}\theta \\
\mathrm{cm}^{3} / \mathrm{cm}^{3}\end{array}$ & $\begin{array}{c}\mathbf{K}(\theta) \\
\mathrm{cm} / \mathrm{dia}\end{array}$ & CAMADA & $\begin{array}{c}q \\
\mathrm{~cm} / \mathrm{dia}\end{array}$ & $\begin{array}{c}v \\
\mathrm{~cm} / \mathrm{dia}\end{array}$ \\
\hline $21 / 07 / 89$ & 82 & 3 & 20 & $-294,60$ & $-274,60$ & $4,59 \mathrm{E}-02$ & $5,83 \mathrm{E}-05$ & & & \\
\hline $21 / 07 / 89$ & 82 & 3 & 60 & $-344,67$ & $-284,67$ & $3,89 \mathrm{E}-02$ & $3,00 \mathrm{E}-05$ & & & $9.65 \mathrm{E}-04$ \\
\hline $21 / 07 / 89$ & 82 & 3 & 100 & $-211,95$ & $-111,95$ & $7,66 \mathrm{E}-02$ & $3,56 \mathrm{E}-03$ & & $-1,18 \mathrm{E}-02$ & $-1,55 E-01$ \\
\hline $21 / 07 / 89$ & 82 & 3 & 140 & & $-99,67$ & & $1,74 \mathrm{E}-02$ & & & \\
\hline & 82 & 3 & 180 & & & $2,72 \mathrm{E}-0 \mathrm{I}$ & $1,50 \mathrm{E}+00$ & & E-01 & $8 \mathrm{E}+00$ \\
\hline $21 / 07 / 89$ & 82 & 3 & 220 & & & $3,14 \mathrm{E}-01$ & $2,65 \mathrm{E}+00$ & & $E+\infty 0$ & $4,10 E+00$ \\
\hline $25 / 07 / 89$ & 86 & 3 & 20 & & & $4,72 \mathrm{E}-02$ & $7,53 \mathrm{E}-05$ & & & \\
\hline $25 / 07 / 89$ & 86 & 3 & 60 & & & $3,95 \mathrm{E}-02$ & & & & $1,23 \mathrm{E}-03$ \\
\hline $25 / 07 / 89$ & 86 & 3 & 100 & & & $7,66 \mathrm{E}-02$ & $3,56 \mathrm{E}-03$ & & $\mathrm{E}-02$ & $-1,45 \mathrm{E}-01$ \\
\hline & 86 & 3 & 140 & & & -01 & & & & $E-01$ \\
\hline & 86 & 3 & 180 & & & $2-01$ & +00 & & -01 & $\mathrm{E}+00$ \\
\hline $25 / 07 / 89$ & 86 & 3 & 220 & & & -01 & $2,65 \mathrm{E}+00$ & & $1,17 \mathrm{E}+00$ & $3,73 E+00$ \\
\hline $27 / 07 / 89$ & 88 & 3 & 20 & & & E-02 & $7,53 \mathrm{E}-05$ & & & \\
\hline $27 / 07 / 89$ & 88 & 3 & 60 & & & $3,98 \mathrm{E}-02$ & $3,92 \mathrm{E}-05$ & & E-0S & $\mathrm{E}-03$ \\
\hline & 88 & 3 & 100 & & & $\mathrm{E}-02$ & -03 & & $\mathrm{E}-02$ & $E-01$ \\
\hline & 88 & 3 & 140 & & & -01 & 1,1 & & & \\
\hline $27 / 07 / 89$ & 88 & 3 & 180 & $-227,07$ & $-47,07$ & $2,67 \mathrm{E}-01$ & $1,34 \mathrm{E}+00$ & $140-180$ & $-7,04 \mathrm{E}-01$ & $-2,64 \mathrm{E}+00$ \\
\hline $27 / 07 / 89$ & 88 & 3 & 220 & & & $2,51 \mathrm{E}-01$ & $7,82 \mathrm{E}-01$ & & $5,91 \mathrm{E}-01$ & $2,35 E+00$ \\
\hline $29 / 07 / 89$ & 90 & 3 & 20 & & & $4,19 \mathrm{E}-02$ & $E-05$ & & & \\
\hline & 90 & 3 & 60 & & & $3,84 \mathrm{E}-02$ & $2,53 \mathrm{E}-05$ & & & $1,25 \mathrm{E}-04$ \\
\hline $29 / 07 / 89$ & 90 & 3 & 100 & & & $8,05 \mathrm{E}-02$ & $4,95 \mathrm{E}-03$ & $60-100$ & $-1,82 \mathrm{E}-02$ & $-2,26 \mathrm{E}-01$ \\
\hline $29 / 07 / 89$ & 90 & 3 & 140 & & & $1,25 \mathrm{E}-01$ & $2,74 \mathrm{E}-02$ & $100-140$ & $1,73 \mathrm{E}-02$ & $1,39 \mathrm{E}-01$ \\
\hline $29 / 07 / 89$ & 90 & 3 & 180 & $-227,07$ & $-47,07$ & $2,67 \mathrm{E}-01$ & $1,34 E+00$ & $140-180$ & $-1,27 \mathrm{E}-01$ & $-4,75 \mathrm{E}-01$ \\
\hline $29 / 07 / 89$ & 90 & 3 & 220 & $-244,70$ & $-24,70$ & $3,14 \mathrm{E}-01$ & $2,65 \mathrm{E}+00$ & $180-220$ & $1,17 \mathrm{E}+00$ & $3,73 \mathrm{E}+00$ \\
\hline
\end{tabular}


Tabela 2 - Resultados dos cálculos de fluxo de água (01/11/89 a 12/12/89)

\begin{tabular}{|c|c|c|c|c|c|c|c|c|c|c|}
\hline DATA & DIA & AREA & $\begin{array}{c}\text { PROF } \\
\mathrm{cm}\end{array}$ & \begin{tabular}{|c} 
POT, HIDR \\
$\mathrm{cm}$
\end{tabular} & $\begin{array}{c}\text { POT. MAT } \\
\mathrm{cm}\end{array}$ & $\begin{array}{c}\theta \\
\mathrm{cm}^{3} / \mathrm{cm}^{3}\end{array}$ & $\begin{array}{c}\mathrm{K}(\theta) \\
\mathrm{cm} / \mathrm{dia}\end{array}$ & CAMADA & $\begin{array}{c}q \\
\mathrm{~cm} / \mathrm{dia}\end{array}$ & $\begin{array}{c}\mathbf{v} \\
\mathrm{cm} / \mathrm{dia}\end{array}$ \\
\hline $01 / 11 / 89$ & 1 & 1 & 20 & $-82,40$ & $-62,40$ & $1,61 \mathrm{E}-01$ & $1,35 \mathrm{E}-01$ & & & \\
\hline $01 / 11 / 89$ & 1 & 1 & 60 & $-176,40$ & $-116,40$ & $7,62 \mathrm{E}-02$ & $5,58 \mathrm{E}-03$ & $20-60$ & $1,31 \mathrm{E}-02$ & $1,72 \mathrm{E}-01$ \\
\hline $01 / 11 / 89$ & 1 & 1 & 100 & $-224,03$ & $-124,03$ & $7,02 \mathrm{E}-02$ & $1,99 \mathrm{E}-03$ & $60-100$ & $2,37 \mathrm{E}-03$ & $3,38 \mathrm{E}-02$ \\
\hline & 1 & 1 & 140 & & & $1,14 \mathrm{E}-01$ & $1,64 \mathrm{E}-02$ & & $6,90 \mathrm{E}-03$ & \\
\hline & 1 & 1 & 180 & & & $2,20 \mathrm{E}-01$ & $4,52 \mathrm{E}-01$ & & $5,51 \mathrm{E}-02$ & $2,51 \mathrm{E}-01$ \\
\hline $01 / 11 / 89$ & 1 & 1 & 220 & $-245,70$ & $-25,70$ & $3,08 \mathrm{E}-01$ & $2,40 \mathrm{E}+00$ & & $0,00 \mathrm{E}+00$ & $0,00 \mathrm{E}+00$ \\
\hline $06 / 11 / 89$ & 6 & 1 & 20 & $-82,40$ & $-62,40$ & $1,61 \mathrm{E}-01$ & $1,35 \mathrm{E}-01$ & & & \\
\hline $06 / 11 / 89$ & 6 & 1 & 60 & $-169,35$ & $-109,35$ & $8,11 \mathrm{E}-02$ & $7,97 \mathrm{E}-03$ & $20-60$ & $1,73 \mathrm{E}-02$ & $2,14 \mathrm{E}-01$ \\
\hline & 6 & 1 & 100 & & & $6,41 \mathrm{E}-02$ & $1,02 \mathrm{E}-03$ & & $1,79 \mathrm{E}-03$ & \\
\hline & 6 & 1 & 140 & & & & & & & \\
\hline $06 / 1$ & 6 & 1 & 180 & & & & $7,54 \mathrm{E}-01$ & & $\mathrm{E}+00$ & $\mathrm{E}+0$ \\
\hline $06 / 11 / 89$ & 6 & 1 & 220 & & & $2,76 \mathrm{E}-01$ & $1,29 \mathrm{E}+00$ & & E-01 & $E+00$ \\
\hline $07 / 11 / 89$ & 7 & 1 & 20 & $-107,60$ & $-87,60$ & & $2,56 \mathrm{E}-02$ & & & \\
\hline & 7 & 1 & 60 & $-194,55$ & & $6,64 \mathrm{E}-02$ & 2,43 & & $E-03$ & $E-02$ \\
\hline & 7 & 1 & 100 & & & & & & -04 & \\
\hline 189 & 7 & 1 & 140 & & & & & & $E-03$ & $\mathrm{E}-02$ \\
\hline $07 / 11 / 89$ & 7 & 1 & 180 & & & $2,21 \mathrm{E}-01$ & $4,69 \mathrm{E}-01$ & & $\mathrm{E}-02$ & E-01 \\
\hline $07 / 11 / 89$ & 7 & 1 & 220 & & & & $2,40 \mathrm{E}+00$ & & & \\
\hline & 9 & 1 & 20 & & & & $9,72 \mathrm{E}-04$ & & & \\
\hline & 9 & 1 & 60 & & & & & & & 02 \\
\hline & 9 & 1 & 100 & & & & & & & \\
\hline $09 / 11 / 89$ & 9 & 1 & 140 & & & & & & E-03 & $\mathrm{E}-02$ \\
\hline & 9 & 1 & 180 & & & & & & $E-02$ & $\mathrm{E}-01$ \\
\hline & 9 & 1 & 220 & & & & 7,14 & & & EE-01 \\
\hline & 14 & 1 & 20 & & & & & & & \\
\hline & 14 & 1 & 60 & & & & & & & \\
\hline & 14 & 1 & 100 & & & & & & & -02 \\
\hline $14 / 11 / 89$ & 14 & 1 & 140 & & & & & & & \\
\hline $14 / 11 / 89$ & 14 & 1 & 180 & & & & 4,6 & & -01 & e-01 \\
\hline & 14 & 1 & 220 & & & & & & & \\
\hline & 16 & 1 & 20 & & & & & & & \\
\hline & 16 & 1 & 60 & & & & 2,26 & & $+\infty$ & +00 \\
\hline & 16 & 1 & 100 & & & & & & & -02 \\
\hline $16 / 11 / 89$ & 16 & 1 & 140 & & & & & & & -02 \\
\hline & 16 & 1 & 180 & & & & & & 02 & \\
\hline & 16 & 1 & 220 & & & & & & & \\
\hline & 18 & 1 & 20 & & & & 1,1 & & & \\
\hline & 18 & 1 & 60 & & & & & & & $+\infty$ \\
\hline $18 / 11 / 89$ & 18 & 1 & 100 & & & $7,53 \mathrm{E}-02$ & & & & \\
\hline & 18 & 1 & 140 & & & & & & & \\
\hline & 18 & 1 & 180 & & & & & & & $2-01$ \\
\hline & 18 & 1 & 220 & & & & $2,40 \mathrm{E}+00$ & $180-220$ & $5,44 \mathrm{E}-01$ & $1,77 \mathrm{E}+00$ \\
\hline $22 / 11 / 89$ & 22 & 1 & 20 & & & $1,99 \mathrm{E}-01$ & $3,73 E$ & & & \\
\hline $22 / 11 / 89$ & 22 & 1 & 60 & & & $1,05 \mathrm{E}-01$ & & & & $2-01$ \\
\hline $22 / 11 / 89$ & 22 & 1 & 100 & & & $8,89 \mathrm{E}-02$ & & & & $8-01$ \\
\hline & 22 & 1 & 140 & & & & & & & \\
\hline & 22 & 1 & 180 & & & & & & & \\
\hline & 22 & 1 & 220 & & & & $2,40 \mathrm{E}+00$ & & & $2,58 \mathrm{E}+00$ \\
\hline $25 / 11 / 89$ & 25 & 1 & 20 & & & $2,29 \mathrm{E}-01$ & & & & \\
\hline $25 / 11 / 89$ & 25 & 1 & 60 & & & $1,75 \mathrm{E}-01$ & $3,80 \mathrm{E}-01$ & & & $2,73 \mathrm{E}+00$ \\
\hline $25 / 11 / 89$ & 25 & 1 & 100 & & & $1,88 \mathrm{E}-01$ & $4,62 \mathrm{E}$ & & & $1,94 \mathrm{E}+00$ \\
\hline & 25 & 1 & 140 & & & & & & & $2,69 \mathrm{E}+00$ \\
\hline & 25 & 1 & 180 & & & & & & $1,42 \mathrm{E}+00$ & $3,79 \mathrm{E}+00$ \\
\hline & 25 & 1 & 220 & & & & $2,48 \mathrm{E}+00$ & $180-220$ & & $8,40 \mathrm{E}-01$ \\
\hline 28/11/89 & 28 & 1 & 20 & & & $2,29 \mathrm{E}-01$ & $7,33 \mathrm{E}-01$ & & & \\
\hline $28 / 11 / 89$ & 28 & 1 & 60 & & & $1,35 \mathrm{E}-01$ & $1,12 \mathrm{E}-01$ & & & $1,35 \mathrm{E}+00$ \\
\hline $28 / 11 / 89$ & 28 & 1 & 100 & & & $1,59 \mathrm{E}-01$ & $2,05 \mathrm{E}-01$ & $60-100$ & & $8,10 \mathrm{E}-01$ \\
\hline & 28 & 1 & 140 & & & & $5,64 \mathrm{E}-01$ & $100-140$ & $4,73 \mathrm{E}-01$ & $2,16 \mathrm{E}+00$ \\
\hline $28 / 11 / 89$ & 28 & 1 & 180 & & & $3,65 \mathrm{E}-01$ & & & $2,24 \mathrm{E}+00$ & $6,12 \mathrm{E}+00$ \\
\hline $28 / 11 / 89$ & 28 & 1 & 220 & $-194,63$ & 25,37 & $3,10 \mathrm{E}-01$ & $2,48 E+00$ & $180-220$ & $0,00 \mathrm{E}+00$ & $0,00 \mathrm{E}+00$ \\
\hline
\end{tabular}


Tabela 2 (continuação)

\begin{tabular}{|c|c|c|c|c|c|c|c|c|c|c|}
\hline DATA & DIA & AREA & $\begin{array}{c}\mathrm{PROF} \\
\mathrm{cm}\end{array}$ & $\begin{array}{c}\text { POT. HIDR } \\
\mathrm{cm}\end{array}$ & $\begin{array}{c}\text { POT. MAT } \\
\mathrm{cm}\end{array}$ & $\mid \begin{array}{c}\theta \\
\mathrm{cm}^{3} / \mathrm{cm}^{3}\end{array}$ & $\begin{array}{c}\mathbf{K}(\theta) \\
\mathrm{cm} / \mathrm{dia}\end{array}$ & CAMADA & $\begin{array}{c}9 \\
\mathrm{~cm} / \mathrm{dia}\end{array}$ & $\begin{array}{c}\mathbf{v} \\
\mathrm{cm} / \mathrm{dia}\end{array}$ \\
\hline $30 / 11 / 89$ & 30 & 1 & 20 & $-62,25$ & $-42,25$ & $2,29 \mathrm{E}-01$ & $7,33 \mathrm{E}-01$ & & & \\
\hline $30 / 11 / 89$ & 30 & 1 & 60 & $-118,95$ & $-58,95$ & $1,56 \mathrm{E}-01$ & $2,21 \mathrm{E}-01$ & $20-60$ & $3,13 \mathrm{E}-01$ & $2,01 \mathrm{E}+00$ \\
\hline $30 / 11 / 89$ & 30 & 1 & 100 & $-148,43$ & $-48,43$ & $1,73 \mathrm{E}-01$ & $3,05 \mathrm{E}-01$ & $60-100$ & $2,25 \mathrm{E}-01$ & $1,30 \mathrm{E}+00$ \\
\hline $30 / 11 / 89$ & 30 & 1 & 140 & & $-25,23$ & $3,14 \mathrm{E}-01$ & $3,78 \mathrm{E}+00$ & $100-140$ & $1,59 E+00$ & $5,05 \mathrm{E}+00$ \\
\hline & 30 & & 80 & $-194,63$ & $-14,63$ & $3,65 \mathrm{E}-01$ & $1,06 \mathrm{E}+01$ & & $7,83 \mathrm{E}+00$ & $2,14 E+01$ \\
\hline $30 / 11 / 89$ & 30 & 1 & 220 & & & $3,49 \mathrm{E}-01$ & $5,01 \mathrm{E}+00$ & $180-220$ & $8,72 \mathrm{E}-01$ & $2,50 \mathrm{E}+00$ \\
\hline $2 / 12 / 89$ & 32 & 1 & 20 & & & $2,29 \mathrm{E}-01$ & $7,33 \mathrm{E}-01$ & & & \\
\hline $2 / 12 / 89$ & 32 & 1 & 60 & $-118,95$ & & $1,56 \mathrm{E}-01$ & $2,21 \mathrm{E}-01$ & & $13 \mathrm{E}-01$ & $2,01 \mathrm{E}+00$ \\
\hline $2 / 12 / 89$ & 32 & 1 & 100 & & $-48,43$ & $1,73 \mathrm{E}-01$ & $3,05 \mathrm{E}-01$ & & $25 \mathrm{E}-01$ & $1,30 \mathrm{E}+00$ \\
\hline $2 / 12 / 89$ & 32 & 1 & 140 & & & $3,35 \mathrm{E}-01$ & $5,54 \mathrm{E}+00$ & & $1,75 \mathrm{E}+00$ & $5,21 \mathrm{E}+00$ \\
\hline & 32 & 1 & 180 & & $-14,63$ & $3,65 \mathrm{E}-01$ & $1,06 \mathrm{E}+01$ & & $8,94 \mathrm{E}+00$ & $2,45 E+01$ \\
\hline 2/12/89 & 32 & 1 & 220 & & & $3,49 \mathrm{E}-01$ & $5,01 E+00$ & & $8,72 \mathrm{E}-01$ & $2,50 \mathrm{E}+00$ \\
\hline $05 / 12 / 89$ & 35 & 1 & 20 & & & $2,04 \mathrm{E}-01$ & $4,16 \mathrm{E}-01$ & & & \\
\hline $05 / 12 / 89$ & 35 & 1 & 60 & & & $1,75 \mathrm{E}-01$ & $3,80 \mathrm{E}-01$ & & $\mathrm{E}-01$ & $2,39 \mathrm{E}+00$ \\
\hline & 35 & 1 & 100 & & & $1,59 \mathrm{E}-01$ & $2,05 \mathrm{E}-01$ & & $\mathrm{E}-01$ & $1,29 \mathrm{E}+00$ \\
\hline & 35 & 1 & 140 & & & & $5,54 \mathrm{E}+00$ & & $6 \mathrm{E}+00$ & $3,47 \mathrm{E}+00$ \\
\hline $2 / 89$ & 35 & 1 & 180 & & & & $1,06 \mathrm{E}+01$ & & $4 \mathrm{E}+00$ & $\mathrm{E}+01$ \\
\hline $05 / 12 / 89$ & 35 & 1 & 220 & & & & $9,17 \mathrm{E}+00$ & & $\mathrm{E}+00$ & $2+00$ \\
\hline $07 / 12 / 89$ & 37 & 1 & 20 & & & $2,04 \mathrm{E}-01$ & $4,16 \mathrm{E}-01$ & & & \\
\hline & 37 & 1 & 60 & & & $1,40 \mathrm{E}-01$ & $1,33 \mathrm{E}-01$ & &, $88 \mathrm{E}-01$ & $1,34 \mathrm{E}+00$ \\
\hline & 37 & 1 & 100 & & & & $3,05 \mathrm{E}-0 \mathrm{l}$ & & $E-01$ & $1,02 \mathrm{E}+00$ \\
\hline & 37 & 1 & & & & & $1,73 \mathrm{E}+00$ & & $E+\infty$ & \\
\hline & 37 & 1 & 180 & & & & $1,06 \mathrm{E}+01$ & & $E+00$ & \\
\hline $07 / 12 / 89$ & 37 & 1 & 220 & & & & $1,42 \mathrm{E}+00$ & & $\mathrm{E}-01$ & $8-01$ \\
\hline & 39 & 1 & 20 & & & & $1,49 \mathrm{E}-01$ & & & \\
\hline & 39 & 1 & 60 & & & & $2,21 \mathrm{E}-01$ & & & \\
\hline & 39 & 1 & & & & & $9,76 \mathrm{E}-02$ & & & \\
\hline & 39 & 1 & 14 & & & & $7,99 \mathrm{E}+00$ & & $E-01$ & $E+00$ \\
\hline & 39 & 1 & & & & & $8,27 \mathrm{E}+00$ & & +00 & +01 \\
\hline & 39 & 1 & 220 & & & & $1,63 E+00$ & & 801 & +00 \\
\hline & 42 & 1 & & & & & $9,35 \mathrm{E}-02$ & & & \\
\hline & 42 & 1 & & & & & $2,21 \mathrm{E}-01$ & & & +00 \\
\hline 121 & 42 & 1 & 100 & & & & $9,76 \mathrm{E}-02$ & & & \\
\hline & 42 & 1 & 14 & & & & $E+00$ & & $E-01$ & $\pm+\infty$ \\
\hline $2 / 89$ & 42 & 1 & & & & & E+01 & & +01 & +01 \\
\hline & 42 & 1 & & & & & $E+\infty$ & & & \\
\hline & 1 & 2 & & & & & $1,64 \mathrm{E}-01$ & & & \\
\hline & 1 & 2 & & & & & $3,45 \mathrm{E}-03$ & & & \\
\hline & 1 & 2 & & & & -02 & $2,38 \mathrm{E}-03$ & & & -02 \\
\hline & 1 & 2 & & & & & $\mathrm{E}-02$ & & $E-04$ & -03 \\
\hline & 1 & 2 & & & & & $6,71 \mathrm{E}-01$ & & & +00 \\
\hline & 1 & 2 & 22 & & & & $5,77 \mathrm{E}+00$ & & & \\
\hline & 6 & 2 & & & & & $2,96 \mathrm{E}-02$ & & & \\
\hline & 6 & 2 & & & & & $1,68 \mathrm{E}-03$ & & & \\
\hline & 6 & 2 & & & & $\mathrm{E}-02$ & $9 \mathrm{E}-04$ & & $\mathrm{E}-04$ & \\
\hline $06 / 11 / 89$ & 6 & 2 & & & & & $4,78 \mathrm{E}-02$ & & $\mathrm{E}-02$ & $\mathrm{E}-01$ \\
\hline $1 / 89$ & 6 & 2 & & & & & $4,71 \mathrm{E}-01$ & & & $E+\infty 0$ \\
\hline & 6 & 2 & & & & & $3,79 \mathrm{E}+00$ & & $-3,58 \mathrm{E}-01$ & $-1,07 \mathrm{E}+00$ \\
\hline & 7 & 2 & & & & $9,29 \mathrm{E}-02$ & $7,78 \mathrm{E}-03$ & & & \\
\hline $1 / 89$ & 7 & 2 & & & & & & & & $4,89 \mathrm{E}-02$ \\
\hline $07 / 11 / 89$ & 7 & 2 & & & & $\mathrm{E}-02$ & & & & -02 \\
\hline $07 / 11 / 89$ & 7 & 2 & 140 & & & & $2,37 \mathrm{E}-02$ & & $\mathrm{E}-02$ & \\
\hline $1 / 89$ & 7 & 2 & & & & $2,08 \mathrm{E}-01$ & $3,37 \mathrm{E}-01$ & & & \\
\hline & 7 & 2 & 22 & & & $\mathrm{E}-01$ & $2,48 \mathrm{E}+00$ & $180-220$ & $-3,65 \mathrm{E}-01$ & $-1,18 \mathrm{E}+00$ \\
\hline & 9 & 2 & & & & $5,95 \mathrm{E}-02$ & $4,82 \mathrm{E}-04$ & & & \\
\hline $09 / 11 / 89$ & 9 & 2 & & & & & & & $\mathrm{E}-04$ & $5,69 \mathrm{E}-03$ \\
\hline $09 / 11 / 89$ & 9 & 2 & 100 & & & $5,32 \mathrm{E}-02$ & $2,12 \mathrm{E}-04$ & & & $4,18 \mathrm{E}-04$ \\
\hline $09 / 11 / 89$ & 9 & 2 & 140 & & & & $9,52 \mathrm{E}-03$ & & & \\
\hline & 9 & 2 & 180 & & & $1,97 \mathrm{E}-01$ & $2,45 \mathrm{E}-01$ & $140-180$ & $3,09 \mathrm{E}-02$ & $1,57 \mathrm{E}-01$ \\
\hline $09 / 11 / 89$ & 9 & 2 & 220 & $-245,37$ & $-25,37$ & $3,10 \mathrm{E}-01$ & $2,48 \mathrm{E}+00$ & $180-220$ & $-7,56 \mathrm{E}-01$ & $-2,44 \mathrm{E}+00$ \\
\hline
\end{tabular}


Tabela 2 (continuação)

\begin{tabular}{|c|c|c|c|c|c|c|c|c|c|c|}
\hline DATA & DIA & ÁRE & $\begin{array}{c}\text { PROF } \\
\mathrm{cm}\end{array}$ & $\begin{array}{c}\text { POT. HIDR } \\
\mathrm{cm}\end{array}$ & $\begin{array}{c}\text { POT. MAT } \\
\mathrm{cm}\end{array}$ & $\begin{array}{c}\theta \\
\mathrm{cm}^{3} / \mathrm{cm}^{3}\end{array}$ & $\begin{array}{c}\mathrm{K}(\theta) \\
\mathrm{cm} / \mathrm{dia} \\
\end{array}$ & CAMADA & $\begin{array}{c}q \\
\mathrm{~cm} / \mathrm{dia}\end{array}$ & $\begin{array}{c}v \\
\mathrm{~cm} / \mathrm{dia}\end{array}$ \\
\hline $14 / 11 / 89$ & 14 & 2 & 20 & & & & & & & \\
\hline & 1 & 2 & & & $-115,65$ & $7,67 \mathrm{E}-02$ & $5,79 \mathrm{E}-03$ & $20-60$ & $2,54 \mathrm{E}-02$ & $3,32 \mathrm{E}-01$ \\
\hline $14 / 11 / 89$ & 14 & 2 & 100 & & $-187,37$ & $5,24 \mathrm{E}-02$ & $1,86 \mathrm{E}-04$ & & $5,18 \mathrm{E}-04$ & $9,88 \mathrm{E}-03$ \\
\hline $14 / 11 / 89$ & 14 & 2 & 140 & & & $1,16 \mathrm{E}-01$ & $1,83 \mathrm{E}-02$ & $100-140$ & $-2,23 \mathrm{E}-02$ & $-1,92 \mathrm{E}-01$ \\
\hline $14 / 11 / 89$ & 14 & 2 & 180 & $-252,50$ & & $2,06 \mathrm{E}-01$ & $3,16 \mathrm{E}-01$ & & $1,09 \mathrm{E}-01$ & $5,31 \mathrm{E}-01$ \\
\hline $14 / 11 / 89$ & 14 & 2 & 220 & & & $2,45 \mathrm{E}-01$ & $6,82 \mathrm{E}-01$ & & $1,07 \mathrm{E}-01$ & $4,38 \mathrm{E}-01$ \\
\hline & 16 & 2 & 20 & & & $7,97 \mathrm{E}-02$ & $3,21 \mathrm{E}-03$ & & & \\
\hline 189 & 16 & 2 & 60 & & & $7,26 \mathrm{E}-02$ & $4,19 \mathrm{E}-03$ & $20-60$ & $3,34 \mathrm{E}-03$ & $4,61 \mathrm{E}-02$ \\
\hline & 16 & 2 & 100 & & & & $3,69 \mathrm{E}-04$ & & $7,75 \mathrm{E}-04$ & $1,37 E-02$ \\
\hline $16 / 11 / 89$ & 16 & 2 & 140 & & & $1,09 \mathrm{E}-01$ & $1,27 \mathrm{E}-02$ & & $-6,40 \mathrm{E}-03$ & $-5,85 \mathrm{E}-02$ \\
\hline $16 / 11 / 89$ & 16 & 2 & 180 & & & $1,97 \mathrm{E}-01$ & $2,45 \mathrm{E}-01$ & & $6,95 \mathrm{E}-02$ & $3,53 \mathrm{E}-01$ \\
\hline & 16 & 2 & 220 & & & $2,05 \mathrm{E}-01$ & $2,61 \mathrm{E}-01$ & & $21 \mathrm{E}-02$ & $1 \mathrm{E}-01$ \\
\hline & 18 & 2 & 20 & & & $9,71 \mathrm{E}-02$ & $9,94 \mathrm{E}-03$ & & & \\
\hline & 18 & 2 & 60 & & & $9,59 \mathrm{E}-02$ & $1,99 \mathrm{E}-02$ & & $38 \mathrm{E}-02$ & $1,44 \mathrm{E}-01$ \\
\hline $1 / 89$ & 18 & 2 & 100 & & & & & & $9 \mathrm{E}-03$ & $8 \mathrm{E}-02$ \\
\hline $18 / 11 / 89$ & 18 & 2 & 140 & & & $8-01$ & E-02 & & E-02 & E-01 \\
\hline & 18 & 2 & 180 & & & E-01 & E-01 & & E-0I & $4 \mathrm{E}-01$ \\
\hline & 18 & 2 & 220 & & & $2,79 \mathrm{E}-01$ & $1,39 \mathrm{E}+00$ & & $\mathrm{E}-01$ & $\mathrm{E}-01$ \\
\hline & 22 & 2 & 20 & & & & $7,34 \mathrm{E}-03$ & & & \\
\hline & 22 & 2 & 60 & & & & & & $2 \mathrm{E}-03$ & $4 \mathrm{E}-01$ \\
\hline & 22 & 2 & 100 & & & & & & E-03 & $\mathrm{E}-02$ \\
\hline 221 & 22 & 2 & 140 & & & & & & $\mathrm{E}-02$ & $\mathrm{E}-01$ \\
\hline & 22 & 2 & 180 & & & E-01 & E-01 & & $\mathrm{E}-01$ & $\mathrm{E}-01$ \\
\hline & 22 & 2 & 220 & & & E-01 & $2,59 \mathrm{E}+00$ & & $\mathrm{E}+00$ & \\
\hline & 25 & 2 & 20 & & & & $1,90 \mathrm{E}+01$ & & & \\
\hline & 25 & 2 & 6 & & & & & & $E-01$ & $28 \mathrm{E}+00$ \\
\hline $1 / 89$ & 25 & 2 & 100 & & & -01 & & & $\mathrm{E}-01$ & $\mathrm{E}+00$ \\
\hline & 25 & 2 & 140 & & & -01 & $E+00$ & & $E+00$ & $E+00$ \\
\hline & 25 & 2 & 180 & & & $2-01$ & $E+01$ & & +00 & $2+01$ \\
\hline & 25 & 2 & 220 & & & & $E+\infty$ & & $E-01$ & $a+0$ \\
\hline & 28 & 2 & 20 & & & & & & & \\
\hline & 28 & 2 & 6 & & & & & & E-01 & $4 \mathrm{E}+00$ \\
\hline & 28 & 2 & 100 & & & & & & -01 & \\
\hline & 28 & 2 & 140 & & & & & & $8-01$ & \\
\hline & 28 & 2 & & & & E-01 & $E+01$ & & & \\
\hline 189 & 28 & 2 & & & & $\mathrm{E}-01$ & E-01 & & $\mathrm{E}-01$ & E-01 \\
\hline & 30 & 2 & 2 & & & E-01 & & & & \\
\hline $30 / 11 / 89$ & 30 & 2 & 60 & & & & & & $E-01$ & $E+00$ \\
\hline $30 / 11 / 89$ & 30 & 2 & 100 & & & & & & $8-01$ & $+\infty$ \\
\hline & 30 & 2 & 140 & & & $\mathrm{E}-01$ & $7 E-01$ & & & \\
\hline & 30 & 2 & & & & $56 \mathrm{E}-01$ & $1,07 \mathrm{E}+01$ & & $E+00$ & \\
\hline $1 / 89$ & 30 & 2 & 220 & & & -01 & $7 \mathrm{E}+00$ & & DE-02 & $4 \mathrm{E}-02$ \\
\hline $2 / 12 / 89$ & 32 & 2 & & & & & & & & \\
\hline $2 / 12 / 89$ & 32 & 2 & 60 & & & & & & $\mathrm{E}-01$ & $E+00$ \\
\hline $2 / 12 / 89$ & 32 & 2 & 100 & & & E-01 & & & $8-01$ & $8+00$ \\
\hline & 32 & 2 & 140 & & & $2,04 \mathrm{E}-01$ & $3.87 \mathrm{E}-01$ & & & \\
\hline $2 / 1$ & 32 & 2 & 180 & & & $3,66 \mathrm{E}-01$ & $1,07 \mathrm{E}+01$ & & $8+00$ & \\
\hline $2 / 12 / 89$ & 32 & 2 & 220 & & & E-01 & $1,69 \mathrm{E}+00$ & & SOE-01 & \\
\hline $05 / 12 / 89$ & 35 & 2 & & & & $\mathrm{E}-01$ & & & & \\
\hline $05 / 12 / 89$ & 35 & 2 & & & & & & & E-01 & $2 E+00$ \\
\hline $05 / 12 / 89$ & 35 & 2 & 100 & & & & & & $\mathrm{E}-01$ & $\mathrm{E}+00$ \\
\hline & 35 & 2 & 140 & & & & $7,85 \mathrm{E}-01$ & & E-01 & $\mathrm{E}+00$ \\
\hline $05 / 12 / 89$ & 35 & 2 & 180 & & & $9 \mathrm{E}-01$ & $7,29 \mathrm{E}+00$ & & & \\
\hline $05 / 12 / 89$ & 35 & 2 & 220 & & & 5E-01 & $3,92 \mathrm{E}+00$ & $180-220$ & $5 \mathrm{E}-01$ & $2 \mathrm{E}-01$ \\
\hline $07 / 12 / 89$ & 37 & 2 & & & & E-01 & $4,01 \mathrm{E}-01$ & & & \\
\hline $07 / 12 / 89$ & 37 & 2 & & & & & E-01 & & $2,69 \mathrm{E}-01$ & $1,74 \mathrm{E}+00$ \\
\hline $07 / 12 / 89$ & 37 & 2 & 100 & $-152,97$ & & & & & E-01 & $1,05 \mathrm{E}+00$ \\
\hline $07 / 12 / 89$ & 37 & 2 & 140 & $-194,97$ & $-54,97$ & $1,92 \mathrm{E}-01$ & & & $2 \mathrm{E}-01$ & $1,52 \mathrm{E}+00$ \\
\hline $07 / 12 / 89$ & 37 & 2 & 180 & $-200,85$ & $-20,85$ & $3,49 \mathrm{E}-01$ & $7,29 \mathrm{E}+00$ & & $1,07 \mathrm{E}+00$ & $3,07 \mathrm{E}+00$ \\
\hline $07 / 12 / 89$ & 37 & 2 & 220 & $-207,57$ & 12,43 & $3,79 \mathrm{E}-01$ & $8,89 \mathrm{E}+00$ & $180-220$ & $1,49 \mathrm{E}+00$ & $3,95 \mathrm{E}+00$ \\
\hline
\end{tabular}


Tabela 2 (continuação)

\begin{tabular}{|c|c|c|c|c|c|c|c|c|c|c|}
\hline DATA & DIA & AREA & $\begin{array}{c}\text { PROF } \\
\mathrm{cm}\end{array}$ & $\begin{array}{c}\text { POT. HIDR } \\
\mathrm{cm}\end{array}$ & $\begin{array}{c}\text { POT. MAT } \\
\mathrm{cm}\end{array}$ & $\begin{array}{c}\theta \\
\mathrm{cm}^{3} / \mathrm{cm}^{3}\end{array}$ & $\begin{array}{c}\mathrm{K}(\theta) \\
\mathrm{cm} / \mathrm{dia}\end{array}$ & CAMADA & $\begin{array}{c}9 \\
\mathrm{~cm} / \mathrm{dia}\end{array}$ & $\begin{array}{c}v \\
\mathrm{~cm} / \mathrm{dia}\end{array}$ \\
\hline $09 / 12 / 89$ & 39 & 2 & 20 & $-82,40$ & $-62,40$ & $1,61 \mathrm{E}-01$ & $1,35 \mathrm{E}-01$ & & & \\
\hline $09 / 12 / 89$ & 39 & 2 & 60 & $-120,20$ & $-60,20$ & $1,53 \mathrm{E}-01$ & $1,99 \mathrm{E}-01$ & $20-60$ & $1,88 \mathrm{E}-01$ & $1,23 E+00$ \\
\hline $09 / 12 / 89$ & 39 & 2 & 100 & $-144,57$ & $-44,57$ & $1,87 \mathrm{E}-01$ & $4,47 \mathrm{E}-01$ & $60-100$ & $2,72 \mathrm{E}-01$ & $1,46 \mathrm{E}+00$ \\
\hline $09 / 12 / 89$ & 39 & 2 & 140 & $-182,37$ & $-42,37$ & $2,34 \mathrm{E}-01$ & $7,85 \mathrm{E}-0 \mathrm{1}$ & $100-140$ & $7,42 \mathrm{E}-01$ & $3,17 \mathrm{E}+00$ \\
\hline $9 / 12 / 89$ & 39 & 2 & 180 & $-199,17$ & $-19,17$ & $3,54 \mathrm{E}-01$ & $8,09 \mathrm{E}+00$ & & $3,40 \mathrm{E}+00$ & $9,60 \mathrm{E}+00$ \\
\hline & 39 & 2 & 220 & $-200,85$ & & $3,44 \mathrm{E}-01$ & $4,64 E+00$ & & $1,95 \mathrm{E}-01$ & $5,66 \mathrm{E}-01$ \\
\hline $2 / 89$ & 42 & 2 & 20 & $-82,40$ & & $1,61 \mathrm{E}-01$ & $1,35 \mathrm{E}-01$ & & & \\
\hline $12 / 12 / 89$ & 42 & 2 & 60 & $-113,90$ & $-53,90$ & $1,71 \mathrm{E}-01$ & $3,40 \mathrm{E}-01$ & $20-60$ & & $1,57 E+00$ \\
\hline $12 / 12 / 89$ & 42 & 2 & 100 & $-148,77$ & 48,77 & $1,72 \mathrm{E}-01$ & $2,95 \mathrm{E}-01$ & & $2,57 \mathrm{E}-01$ & $1,50 \mathrm{E}+00$ \\
\hline $12 / 12 / 89$ & 42 & 2 & 140 & $-194,55$ & $-54,55$ & $1,93 \mathrm{E}-01$ & $2,87 \mathrm{E}-01$ & & $3,29 \mathrm{E}-01$ & $1,70 \mathrm{E}+00$ \\
\hline & 42 & 2 & 180 & $-203,37$ & & $3,42 \mathrm{E}-01$ & $6,21 \mathrm{E}+00$ & & $1,37 E+00$ & $\overline{\mathrm{E}+00}$ \\
\hline & 42 & 2 & 220 & 45 & & E-01 & $1,46 \mathrm{E}+01$ & & $3,68 \mathrm{E}+00$ & $8+00$ \\
\hline & 1 & 3 & 20 & $-80,90$ & -60 & $1,65 \mathrm{E}-01$ & $1,52 \mathrm{E}-01$ & & & \\
\hline $01 / 11 / 89$ & 1 & 3 & 60 & $-201,87$ & & $6,33 \mathrm{E}-02$ & $1,78 \mathrm{E}-03$ & & & $8,53 \mathrm{E}-02$ \\
\hline & 1 & 3 & 100 & $-227,07$ & $-127,07$ & E-02 & $1,73 \mathrm{E}-03$ & & & $2-02$ \\
\hline & 1 & 3 & 140 & $-218,25$ & & 1,42 & $5,63 \mathrm{E}-02$ & & -02 & -02 \\
\hline & 1 & 3 & 180 & & & -01 & $1,04 \mathrm{E}+00$ & & & \pm+00 \\
\hline & 1 & 3 & 220 & $-244,20$ & & $E-01$ & $2,79 \mathrm{E}+00$ & & & $2,85 \mathrm{E}+00$ \\
\hline & 6 & 3 & 20 & $-80,90$ & & & $1,52 \mathrm{E}-01$ & & & \\
\hline & 6 & 3 & 60 & $-218,67$ & -15 & $5,75 \mathrm{E}-02$ & $9,31 \mathrm{E}-04$ & & $3,21 \mathrm{E}-03$ & E-02 \\
\hline & 6 & 3 & 100 & & & $6,71 \mathrm{E}-02$ & 1,44 & & & \\
\hline & 6 & 3 & 140 & & & & & & & 01 \\
\hline & 6 & 3 & 180 & & & & $8,07 \mathrm{E}-01$ & & & +00 \\
\hline & 6 & 3 & 220 & 20 & & $2-01$ & $2,79 \mathrm{E}+00$ & & & $E+00$ \\
\hline & 7 & 3 & 20 & & & & & & & \\
\hline & 7 & 3 & 60 & 27 & & -02 & 5,9 & & & \\
\hline & 7 & 3 & 100 & & & -02 & & & & \\
\hline & 7 & 3 & 140 & & & 1,3 & $3,89 \mathrm{E}$ & & & -01 \\
\hline & 7 & 3 & 180 & & & & $8,07 \mathrm{E}-01$ & & & -01 \\
\hline & 7 & 3 & 220 & & & 3,1 & $2,79 \mathrm{E}+00$ & & & +00 \\
\hline & 9 & 3 & 20 & & & & & & & \\
\hline & 9 & 3 & 6 & & & & & & & \\
\hline & 9 & 3 & 100 & & & & 1,9 & & & \\
\hline & 9 & 3 & 140 & & & & 1,08 & & & .02 \\
\hline & 9 & 3 & 180 & & & & & & & \\
\hline & 9 & 3 & 220 & 80 & & & & & & \\
\hline & 14 & 3 & 20 & & & & & & & \\
\hline & 14 & 3 & 60 & & & & & & & \\
\hline & 14 & 3 & 100 & & & & & & & \\
\hline & 14 & 3 & 140 & & & & $3,89 \mathrm{E}-02$ & & & $2-01$ \\
\hline$/ 111 / 89$ & 14 & 3 & 180 & & & & $6,33 \mathrm{E}-01$ & & & $+\infty$ \\
\hline & 14 & 3 & 220 & & & & & & & \\
\hline & 16 & 3 & 20 & & & & & & & \\
\hline & 16 & 3 & 60 & & & & & & & \\
\hline 16/11/89 & 16 & 3 & 100 & & & & $4,84 \mathrm{E}-03$ & & & $2 E-02$ \\
\hline $16 / 11 / 89$ & 16 & 3 & 140 & & & & $3,89 \mathrm{E}-02$ & & & $1,35 \mathrm{E}-01$ \\
\hline $16 / 11 / 89$ & 16 & 3 & 180 & & & & $5,00 \mathrm{E}-01$ & & & +00 \\
\hline & 16 & 3 & 220 & & & & $1,49 E+00$ & & & \\
\hline & 18 & 3 & 20 & & & & & & & \\
\hline & 18 & 3 & 60 & & & & $3,69 \mathrm{E}-02$ & & & \\
\hline & 18 & 3 & 100 & & & & $1,27 \mathrm{E}-02$ & & & $1,56 \mathrm{E}-01$ \\
\hline $18 / 11 / 89$ & 18 & 3 & 140 & $-211,95$ & & $1,53 \mathrm{E}_{-01}$ & $8,36 \mathrm{E}-02$ & $100-140$ & $4,74 \mathrm{E}-02$ & $3,11 \mathrm{E}-01$ \\
\hline $18 / 11 / 89$ & 18 & 3 & 180 & $-227,07$ & & E-01 & $1,34 \mathrm{E}+00$ & & $5,07 \mathrm{E}-01$ & $1,90 \mathrm{E}+00$ \\
\hline $18 / 11 / 89$ & 18 & 3 & 220 & & & & $9.59 \mathrm{E}+00$ & & $1,09 \mathrm{E}+00$ & $2,84 \mathrm{E}+00$ \\
\hline & 22 & 3 & 20 & & & & & & & \\
\hline $22 / 11 / 89$ & 22 & 3 & 60 & $-147,27$ & $-87,27$ & $1,03 \mathrm{E}-01$ & $2,82 \mathrm{E}-02$ & & & \\
\hline $22 / 11 / 89$ & 22 & 3 & 100 & $-180,87$ & $-80,87$ & $1,04 \mathrm{E}-01$ & $2,19 E-02$ & $60-100$ & & $1,77 \mathrm{E}-01$ \\
\hline $22 / 11 / 89$ & 22 & 3 & 140 & $-218,25$ & $-78,25$ & $1,42 \mathrm{E}-01$ & $5,63 \mathrm{E}_{-02}$ & $100-140$ & $5,27 \mathrm{E}-02$ & $3,71 \mathrm{E}-01$ \\
\hline $22 / 11 / 89$ & 22 & 3 & 180 & $-239,67$ & $-59,67$ & $2,34 \mathrm{E}-0 \mathrm{t}$ & $6,33 \mathrm{E}-01$ & $140-180$ & $3,39 E-01$ & $1,45 \mathrm{E}+00$ \\
\hline $22 / 11 / 89$ & 22 & 3 & 220 & $-231,60$ & $-11,60$ & $3,82 \mathrm{E}-0 \mathrm{I}$ & $9,59 \mathrm{E}+00$ & $180-220$ & $-1,94 \mathrm{E}+00$ & $-5,06 \mathrm{E}+00$ \\
\hline
\end{tabular}


Tabela 2 (continuação)

\begin{tabular}{|c|c|c|c|c|c|c|c|c|c|c|}
\hline DATA & DIA & ÁREA & $\begin{array}{c}\text { PROF } \\
\mathrm{cm}\end{array}$ & $\begin{array}{c}\text { POT. HIDR } \\
\mathrm{cm}\end{array}$ & {$\left[\begin{array}{c}\text { POT. MAT } \\
\mathrm{cm}\end{array}\right.$} & $\begin{array}{c}\theta \\
\mathrm{cm}^{3} / \mathrm{cm}^{3}\end{array}$ & $\begin{array}{c}\mathrm{K}(\theta) \\
\mathrm{cm} / \mathrm{dia}\end{array}$ & CAMADA & $\begin{array}{c}q \\
\mathrm{~cm} / \mathrm{dia}\end{array}$ & $\begin{array}{c}v \\
\mathrm{~cm} / \mathrm{dia}\end{array}$ \\
\hline $25 / 11 / 89$ & 25 & 3 & 20 & & & & & & & \\
\hline $25 / 11 / 89$ & 25 & 3 & 60 & $-101,07$ & $-41,07$ & $2,20 \mathrm{E}-01$ & $1,11 E+00$ & $20-60$ & $2,81 \mathrm{E}+00$ & $1,27 \mathrm{E}+01$ \\
\hline $25 / 11 / 89$ & 25 & 3 & 100 & $-155,67$ & $-55,67$ & $1,51 \mathrm{E}-01$ & $1,55 \mathrm{E}-01$ & $60-100$ & $2,12 \mathrm{E}-01$ & $1,41 E+00$ \\
\hline $25 / 11 / 89$ & 25 & 3 & 140 & $-180,87$ & $-40,87$ & $2,40 \mathrm{E}-01$ & $8,96 \mathrm{E}-01$ & $100-140$ & $5,64 \mathrm{E}-01$ & $2,35 E+00$ \\
\hline $25 / 11 / 89$ & 25 & 3 & 180 & $-197,67$ & $-17,67$ & $3,58 \mathrm{E}-01$ & $8,88 \mathrm{E}+00$ & & $3,73 \mathrm{E}+00$ & $1,04 \mathrm{E}+01$ \\
\hline & 25 & 3 & 220 & $-193,80$ & 26,20 & $3,06 \mathrm{E}-01$ & $2,28 \mathrm{E}+00$ & & $-2,21 \mathrm{E}-01$ & $-7,23 \mathrm{E}-01$ \\
\hline $28 / 11 / 89$ & 28 & 3 & 20 & & & & & & & \\
\hline $28 / 11 / 89$ & 28 & 3 & 60 & $-109,47$ & $-49,47$ & $1,86 \mathrm{E}-01$ & $5,06 \mathrm{E}-01$ & $20-60$ & $1,38 \mathrm{E}+00$ & $7,43 E+00$ \\
\hline $28 / 11 / 89$ & 28 & 3 & 100 & $-159,87$ & $-59,87$ & $1,40 \mathrm{E}-01$ & $1,08 \mathrm{E}-01$ & & $1,36 \mathrm{E}-01$ & $9,69 \mathrm{E}-01$ \\
\hline $28 / 11 / 89$ & 28 & 3 & 140 & $-180,87$ & $-40,87$ & $2,40 \mathrm{E}-01$ & $8,96 \mathrm{E}-0 \mathrm{t}$ & & & \\
\hline & 28 & 3 & 180 & & $-17,67$ & $3,58 \mathrm{E}-01$ & $8,88 \mathrm{E}+00$ & & $3,73 \mathrm{E}+00$ & $4 \mathrm{E}+01$ \\
\hline & 28 & 3 & 220 & & & E-01 & $7,98 \mathrm{E}+00$ & & $1,74 \mathrm{E}+00$ & \\
\hline $11 / 89$ & 30 & 3 & 20 & & & $2,97 \mathrm{E}-01$ & $2,65 \mathrm{E}+00$ & & & \\
\hline $30 / 11 / 89$ & 30 & 3 & 60 & & $-53,67$ & $1,72 \mathrm{E}-01$ & $3,47 \mathrm{E}-01$ & & & $3,27 \mathrm{E}+00$ \\
\hline $30 / 11 / 89$ & 30 & 3 & 100 & & $-55,67$ & $1,51 \mathrm{E}-01$ & $1,55 \mathrm{E}-01$ & & E-01 & $1,08 \mathrm{E}+00$ \\
\hline $30 / 11 / 89$ & 30 & 3 & 140 & & $-49,27$ & $\mathrm{E}-01$ & $4,38 \mathrm{E}-01$ & 140 & $8-01$ & $E+00$ \\
\hline & 30 & 3 & 180 & & & $2-01$ & $1,44 \mathrm{E}+01$ & & +00 & $+\infty$ \\
\hline $30 / 11 / 89$ & 30 & 3 & 220 & & & E-01 & $2,28 \mathrm{E}+00$ & & & $E-01$ \\
\hline $2 / 12 / 89$ & 32 & 3 & 20 & & 3,90 & $2,97 \mathrm{E}-01$ & $2,65 E+00$ & & & \\
\hline $2 / 12 / 89$ & 32 & 3 & 60 & & & $1,72 \mathrm{E}-01$ & $3,47 \mathrm{E}-01$ & & & $E+00$ \\
\hline $2 / 12 / 89$ & 32 & 3 & 100 & & $-55,67$ & $1,51 \mathrm{E}-01$ & $1,55 \mathrm{E}-01$ & & -01 & $1,08 \mathrm{E}+00$ \\
\hline & 32 & 3 & 140 & & 27 & E-01 & $\mathrm{E}-01$ & & & +00 \\
\hline & 32 & 3 & 180 & & & 201 & $1,44 \mathrm{E}+01$ & & & \\
\hline $02 / 12 / 89$ & 32 & 3 & 220 & & & -01 & $1,23 \mathrm{E}+00$ & & $E-02$ & E-01 \\
\hline $05 / 12 / 89$ & 35 & 3 & 20 & & & 801 & $2,60 \mathrm{E}-01$ & & & \\
\hline & 35 & 3 & 60 & & & $1,72 \mathrm{E}-01$ & & & & +00 \\
\hline & 35 & 3 & 100 & & & $1,77 \mathrm{E}-0 \mathrm{1}$ & E-01 & & -01 & +00 \\
\hline & 35 & 3 & 14 & & & $\mathrm{E}-01$ & $\mathrm{E}-01$ & & & \pm+00 \\
\hline & 35 & 3 & & & & $2-01$ & $1,14 \mathrm{E}+01$ & & +00 & $+\infty$ \\
\hline $05 / 12 / 89$ & 35 & 3 & & & & -01 & $2,28 \mathrm{E}+00$ & & & \\
\hline $07 / 12 / 89$ & 37 & 3 & 20 & & & $1,85 \mathrm{E}-01$ & $2,60 \mathrm{E}-01$ & & & \\
\hline $07 / 12 / 89$ & 37 & 3 & 60 & & & $1,72 \mathrm{E}-01$ & $3,47 \mathrm{E}-01$ & & $\mathrm{E}-01$ & $2,00 \mathrm{E}+00$ \\
\hline & 37 & 3 & & & & E-01 & $\mathrm{E}-01$ & & & +00 \\
\hline & 37 & 3 & & & & -01 & 1,9 & & & \\
\hline $07 / 12 / 89$ & 37 & 3 & 180 & & & $3,68 \mathrm{E}-01$ & $1,14 \mathrm{E}+01$ & & $-1,82 \mathrm{E}+00$ & $3 \mathrm{E}+00$ \\
\hline $07 / 12 / 89$ & 37 & 3 & 220 & & & $3,40 \mathrm{E}-01$ & $4,31 \mathrm{E}+00$ & & & $2,10 \mathrm{E}+00$ \\
\hline $09 / 12 / 89$ & 39 & 3 & 20 & & & $1,85 \mathrm{E}-01$ & $2,60 \mathrm{E}-01$ & & & \\
\hline $09 / 12 / 89$ & 39 & 3 & 60 & & & $1,72 \mathrm{E}-01$ & $3,47 \mathrm{E}-01$ & & & $2,00 \mathrm{E}+00$ \\
\hline & 39 & 3 & & & & E-01 & 5,2 & & & +00 \\
\hline & 39 & 3 & & & & $1,79 \mathrm{E}-01$ & $1,93 \mathrm{E}-01$ & & & $3 \mathrm{E}+00$ \\
\hline $09 / 12 / 89$ & 39 & 3 & 180 & & & & $1,14 \mathrm{E}+01$ & $140-180$ & $-1,82 \mathrm{E}+00$ & $-4,93 E+00$ \\
\hline $09 / 12 / 89$ & 39 & 3 & 220 & $-187,50$ & 32,50 & $2,73 \mathrm{E}-01$ & $1,23 \mathrm{E}+00$ & $180-220$ & $-1,83 \mathrm{E}-01$ & $-6,70 \mathrm{E}-01$ \\
\hline $12 / 12 / 89$ & 42 & 3 & 20 & & 40 & $1,67 \mathrm{E}-01$ & $1,58 \mathrm{E}-01$ & & & \\
\hline $12 / 12 / 89$ & 42 & 3 & 60 & & & $1,48 \mathrm{E}-01$ & $1,71 \mathrm{E}-01$ & & & $E+00$ \\
\hline $12 / 12 / 89$ & 42 & 3 & 100 & & & $1,77 \mathrm{E}-01$ & $3,41 \mathrm{E}-01$ & & $2,15 \mathrm{E}-01$ & $1,22 \mathrm{E}+00$ \\
\hline $12 / 12 / 89$ & 42 & 3 & 140 & $-193,55$ & -53.55 & $1,96 \mathrm{E}-01$ & $3,11 \mathrm{E}-01$ & $100-140$ & $3,59 \mathrm{E}-01$ & $1,84 \mathrm{E}+00$ \\
\hline $12 / 12 / 89$ & 42 & 3 & 180 & & $-9,27$ & $3,76 \mathrm{E}-01$ & $1,44 \mathrm{E}+01$ & $140-180$ & $-1,54 \mathrm{E}+00$ & $-4,09 \mathrm{E}+00$ \\
\hline $12 / 12 / 89$ & 42 & 3 & 220 & $-174,90$ & 45,10 & $2,21 \mathrm{E}-01$ & $3,94 \mathrm{E}-01$ & $180-220$ & $-1,41 \mathrm{E}-01$ & $-6,40 \mathrm{E}-01$ \\
\hline
\end{tabular}


ANEXO 2 


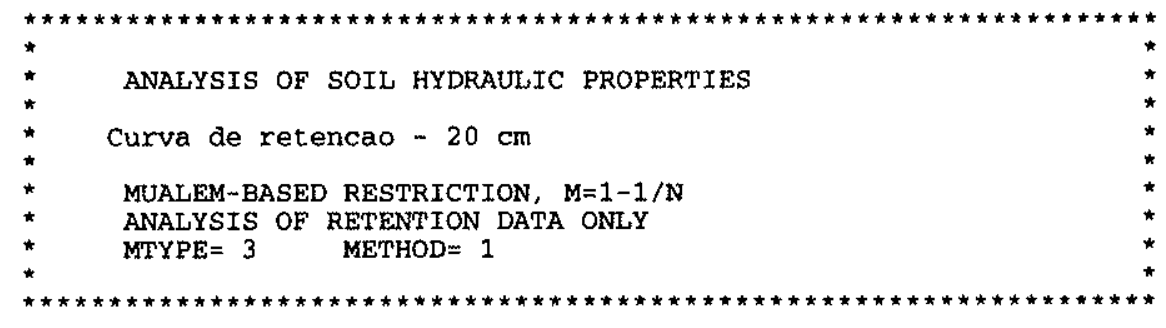

\begin{tabular}{|c|c|c|c|}
\hline NO & NAME & INTTIAL VALUE & INDEX \\
\hline 1 & WCR & .0266 & 0 \\
\hline 2 & WCS & .4046 & 0 \\
\hline 3 & ALPHA & .0050 & 1 \\
\hline 4 & $\mathrm{~N}$ & 2.0000 & 1. \\
\hline 5 & $M$ & .5000 & 0 \\
\hline 6 & EXPO & .5000 & 0 \\
\hline 7 & CONDS & .0003 & 0 \\
\hline
\end{tabular}

\section{OBSERVED DATA
$=====\bar{m}=\overline{=}===$}

\begin{tabular}{|c|c|c|c|c|}
\hline OBS. NO. & $\begin{array}{c}\text { PRESSURE HEAD } \\
.000 \\
14.500 \\
27.500 \\
40.500 \\
83.500 \\
344.420 \\
1033.200 \\
3099.820 \\
5166.360 \\
15499.080\end{array}$ & WATER & $\begin{array}{l}\text { CONTENT } \\
.4046 \\
.3896 \\
.2909 \\
.2418 \\
.1253 \\
.0340 \\
.0301 \\
.0286 \\
.0277 \\
.0266\end{array}$ & $\begin{array}{r}\text { WEIGHTING C } \\
1.0000 \\
1.0000 \\
1.0000 \\
1.0000 \\
1.0000 \\
1.0000 \\
1.0000 \\
1.0000 \\
1.0000 \\
1.0000\end{array}$ \\
\hline
\end{tabular}

$\begin{array}{cllc}\text { NIT } & \text { SSQ } & \text { ALPHA } & \text { N } \\ 0 & .13766 & .0050 & 2.0000 \\ 1 & .08266 & .0089 & 2.0918 \\ 2 & .03495 & .0156 & 2.1373 \\ 3 & .00508 & .0296 & 1.9786 \\ 4 & .00059 & .0319 & 2.2732 \\ 5 & .00050 & .0311 & 2.3876 \\ 6 & .00050 & .0312 & 2.3824 \\ 7 & .00050 & .0312 & 2.3833 \\ 8 & .00050 & .0312 & 2.3832\end{array}$

\section{CORRELATION MATRIX}

$$
\begin{aligned}
& ===\pi= \pm==\pi=\pi=m=\pi \\
& 1 \quad 1.0000 \\
& 2 \quad-.7440 \quad 1.0000
\end{aligned}
$$

RSQUARED FOR REGRESSION OF OBSERVED VS FITTED VALUES $=.99785489$

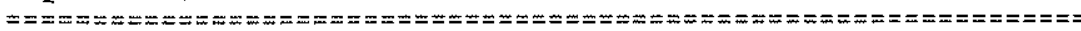

NONLINEAR LEAST-SQUARES ANALYSIS: FINAL RESULTS

\begin{tabular}{|c|c|c|c|c|c|}
\hline $\begin{array}{r}\text { NO } \\
1 \\
2 \\
3 \\
4 \\
5 \\
6 \\
7 \\
8 \\
9 \\
10\end{array}$ & $\begin{array}{c}\mathrm{P} \\
.1000 \mathrm{D}-04 \\
.1450 \mathrm{D}+02 \\
.2750 \mathrm{D}+02 \\
.4050 \mathrm{D}+02 \\
.8350 \mathrm{D}+02 \\
.3444 \mathrm{D}+03 \\
.1033 \mathrm{D}+04 \\
.3100 \mathrm{D}+04 \\
.5166 \mathrm{D}+04 \\
.1550 \mathrm{D}+05\end{array}$ & $\begin{array}{r}\text { LOG-P } \\
-5.0000 \\
1.1614 \\
1.4393 \\
1.6075 \\
1.9217 \\
2.5371 \\
3.0142 \\
3.4913 \\
3.7132 \\
4.1903\end{array}$ & $\begin{array}{r}\text { WC-OBS } \\
.4046 \\
.3896 \\
.2909 \\
.2418 \\
.1253 \\
.0340 \\
.0301 \\
.0286 \\
.0277 \\
.0266\end{array}$ & $\begin{array}{l}\text { WC-FIT } \\
.4046 \\
.3749 \\
.3048 \\
.2367 \\
.1215 \\
.0407 \\
.0297 \\
.0273 \\
.0269 \\
.0267\end{array}$ & $\begin{array}{r}\text { WC-DTF } \\
.0000 \\
.0147 \\
-.0139 \\
.0051 \\
.0038 \\
.0067 \\
.0004 \\
.0013 \\
.0008 \\
-.0001\end{array}$ \\
\hline
\end{tabular}

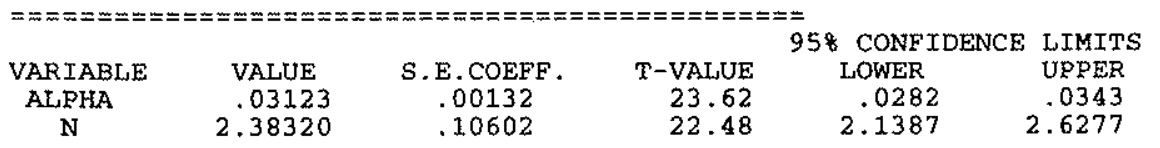

OBSERVED AND FITTED DATA 
SUM OF SQUARES OF OBSERVED VERSUS FITTED VALUES SUM OF SQUARES OF OBSERVED VERSUS FITMD VALU

\begin{tabular}{|c|c|c|c|}
\hline & & UNWEIGHTED & WETGHTED \\
\hline ETENTION & DATA & .00050 & \\
\hline OND/DI & DAT & 000 & \\
\hline$A I$ & DATA & .00050 & \\
\hline
\end{tabular}

SOTL HYDRAULIC PROPERTIES (MTYPE = 3)

\begin{tabular}{|c|c|c|c|c|c|c|}
\hline $\begin{array}{c}\text { WC } \\
.0290 \\
.0313 \\
.0361 \\
.0455 \\
.0550 \\
.0644 \\
.0739 \\
.0833 \\
.0928 \\
.1022 \\
.1117 \\
.1211 \\
.1306 \\
.1400 \\
.1495 \\
.1589 \\
.1684 \\
.1778 \\
.1873 \\
.1967 \\
.2062 \\
.2156 \\
.2251 \\
.2345 \\
.2440 \\
.2534 \\
.2629 \\
.2723 \\
.2818 \\
.2912 \\
.3007 \\
.3101 \\
.3196 \\
.3290 \\
.3385 \\
.3479 \\
.3574 \\
.3668 \\
.376395 \\
.3046\end{array}$ & $\begin{array}{c}P \\
.1256 \mathrm{D}+04 \\
.7607 \mathrm{D}+03 \\
.4606 \mathrm{D}+03 \\
.2786 \mathrm{D}+03 \\
.2073 \mathrm{D}+03 \\
.1678 \mathrm{D}+03 \\
.1423 \mathrm{D}+03 \\
.1242 \mathrm{D}+03 \\
.1105 \mathrm{D}+03 \\
.9977 \mathrm{D}+02 \\
.9105 \mathrm{D}+02 \\
.8378 \mathrm{D}+02 \\
.7761 \mathrm{D}+02 \\
.7227 \mathrm{D}+02 \\
.6760 \mathrm{D}+02 \\
.6345 \mathrm{D}+02 \\
.5973 \mathrm{D}+02 \\
.5637 \mathrm{D}+02 \\
.5330 \mathrm{D}+02 \\
.5047 \mathrm{D}+02 \\
.4786 \mathrm{D}+02 \\
.4543 \mathrm{D}+02 \\
.4314 \mathrm{D}+02 \\
.4099 \mathrm{D}+02 \\
.3895 \mathrm{D}+02 \\
.3700 \mathrm{D}+02 \\
.3513 \mathrm{D}+02 \\
.3333 \mathrm{D}+02 \\
.3159 \mathrm{D}+02 \\
.2989 \mathrm{D}+02 \\
.2823 \mathrm{D}+02 \\
.2658 \mathrm{D}+02 \\
.2494 \mathrm{D}+02 \\
.2330 \mathrm{D}+02 \\
.2164 \mathrm{D}+02 \\
.1993 \mathrm{D}+02 \\
.1816 \mathrm{D}+02 \\
.1627 \mathrm{D}+02 \\
.1419 \mathrm{D}+02 \\
.1179 \mathrm{D}+02 \\
.8682 \mathrm{D}+01 \\
.6444 \mathrm{D}+01 \\
.0000 \mathrm{D}+00 \\
\end{array}$ & $\begin{array}{l}\text { LOGP } \\
3.099 \\
2.881 \\
2.663 \\
2.445 \\
2.317 \\
2.225 \\
2.153 \\
2.094 \\
2.043 \\
1.999 \\
1.959 \\
1.923 \\
1.890 \\
1.859 \\
1.830 \\
1.802 \\
1.776 \\
1.751 \\
1.727 \\
1.703 \\
1.680 \\
1.657 \\
1.635 \\
1.613 \\
1.590 \\
1.568 \\
1.546 \\
1.523 \\
1.500 \\
1.476 \\
1.451 \\
1.425 \\
1.397 \\
1.367 \\
1.335 \\
1.300 \\
1.259 \\
1.211 \\
1.152 \\
1.071 \\
.939 \\
.809\end{array}$ & $\begin{array}{l}\text { COND } \\
.1701 \mathrm{D}-12 \\
.2622 \mathrm{D}-11 \\
.4043 \mathrm{D}-10 \\
.6241 \mathrm{D}-09 \\
.3099 \mathrm{D}-08 \\
.9673 \mathrm{D}-08 \\
.2342 \mathrm{D}-07 \\
.4830 \mathrm{D}-07 \\
.8919 \mathrm{D}-07 \\
.1519 \mathrm{D}-06 \\
.2433 \mathrm{D}-06 \\
.3712 \mathrm{D}-06 \\
.5447 \mathrm{D}-06 \\
.7741 \mathrm{D}-06 \\
.1071 \mathrm{D}-05 \\
.1448 \mathrm{D}-05 \\
.1920 \mathrm{D}-05 \\
.2504 \mathrm{D}-05 \\
.3217 \mathrm{D}-05 \\
.4080 \mathrm{D}-05 \\
.5116 \mathrm{D}-05 \\
.6350 \mathrm{D}-05 \\
.7812 \mathrm{D} \sim 05 \\
.9534 \mathrm{D}-05 \\
.1155 \mathrm{D}-04 \\
.1391 \mathrm{D}-04 \\
.1665 \mathrm{D}-04 \\
.1984 \mathrm{D}-04 \\
.2353 \mathrm{D}-04 \\
.2781 \mathrm{D}-04 \\
.3275 \mathrm{D}-04 \\
.3848 \mathrm{D}-04 \\
.4511 \mathrm{D}-04 \\
.5283 \mathrm{D}-04 \\
.6182 \mathrm{D}-04 \\
.7239 \mathrm{D}-04 \\
.8492 \mathrm{D}-04 \\
.9998 \mathrm{D} \sim 04 \\
.1185 \mathrm{D}-03 \\
.1422 \mathrm{D}-03 \\
.1751 \mathrm{D}-03 \\
.1991 \mathrm{D}-03 \\
.2515 \mathrm{D}-03\end{array}$ & $\begin{array}{l}\text { LOGK } \\
-12.769 \\
-11.581 \\
-10.393 \\
-9.205 \\
-8.509 \\
-8.014 \\
-7.630 \\
-7.316 \\
-7.050 \\
-6.818 \\
-6.614 \\
-6.430 \\
-6.264 \\
-6.111 \\
-5.970 \\
-5.839 \\
-5.717 \\
-5.601 \\
-5.493 \\
-5.389 \\
-5.291 \\
-5.197 \\
-5.107 \\
-5.021 \\
-4.937 \\
-4.857 \\
-4.778 \\
-4.702 \\
-4.628 \\
-4.556 \\
-4.485 \\
-4.415 \\
-4.346 \\
-4.277 \\
-4.209 \\
-4.140 \\
-4.071 \\
-4.000 \\
-3.926 \\
-3.847 \\
-3.757 \\
-3.701 \\
-3.599\end{array}$ & $\begin{array}{c}\text { DIF } \\
.6538 \mathrm{D}-07 \\
.3053 \mathrm{D}-06 \\
.1427 \mathrm{D}-05 \\
.6690 \mathrm{D}-05 \\
.1657 \mathrm{D}-04 \\
.3165 \mathrm{D}-04 \\
.5245 \mathrm{D}-04 \\
.7949 \mathrm{D}-04 \\
.1133 \mathrm{D}-03 \\
.1546 \mathrm{D}-03 \\
.2039 \mathrm{D}-03 \\
.2620 \mathrm{D}-03 \\
.3297 \mathrm{D}-03 \\
.4079 \mathrm{D}-03 \\
.4978 \mathrm{D}-03 \\
.6004 \mathrm{D}-03 \\
.7173 \mathrm{D}-03 \\
.8501 \mathrm{D}-03 \\
.1001 \mathrm{D}-02 \\
.1171 \mathrm{D}-02 \\
.1364 \mathrm{D}-02 \\
.1583 \mathrm{D}-02 \\
.1831 \mathrm{D}-02 \\
.2113 \mathrm{D}-02 \\
.2435 \mathrm{D}-02 \\
.2803 \mathrm{D}-02 \\
.3226 \mathrm{D}-02 \\
.3714 \mathrm{D}-02 \\
.4282 \mathrm{D}-02 \\
.4947 \mathrm{D}-02 \\
.5733 \mathrm{D}-02 \\
.6673 \mathrm{D}-02 \\
.7813 \mathrm{D}-02 \\
.9220 \mathrm{D}-02 \\
.1099 \mathrm{D}-01 \\
.1329 \mathrm{D}-01 \\
.1640 \mathrm{D}-01 \\
.2082 \mathrm{D}-01 \\
.2766 \mathrm{D}-01 \\
.3989 \mathrm{D}-01 \\
.6986 \mathrm{D}-01 \\
.1159 \mathrm{D}+00\end{array}$ & $\begin{array}{l}\text { LOGD } \\
-7.185 \\
-6.515 \\
-5.846 \\
-5.175 \\
-4.781 \\
-4.500 \\
-4.280 \\
-4.100 \\
-3.946 \\
-3.811 \\
-3.691 \\
-3.582 \\
-3.482 \\
-3.389 \\
-3.303 \\
-3.222 \\
-3.144 \\
-3.071 \\
-3.000 \\
-2.931 \\
-2.865 \\
-2.801 \\
-2.737 \\
-2.675 \\
-2.613 \\
-2.552 \\
-2.491 \\
-2.430 \\
-2.368 \\
-2.306 \\
-2.242 \\
-2.176 \\
-2.107 \\
-2.035 \\
-1.959 \\
-1.876 \\
-1.785 \\
-1.682 \\
-1.558 \\
-1.399 \\
-1.156 \\
-.936\end{array}$ \\
\hline
\end{tabular}




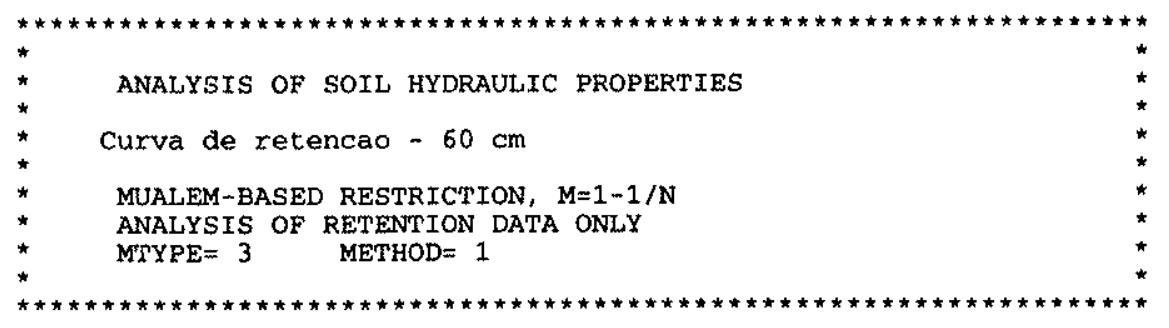

INITIAL VALUES OF THE COEFFICIENTS

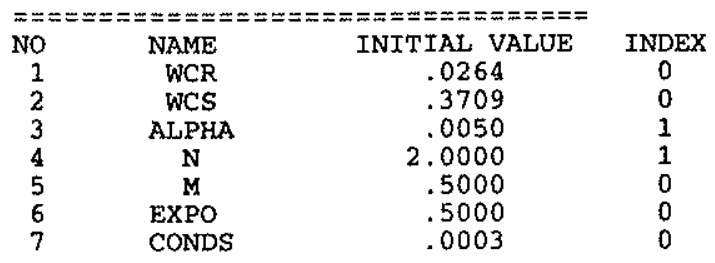

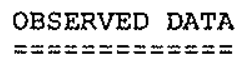

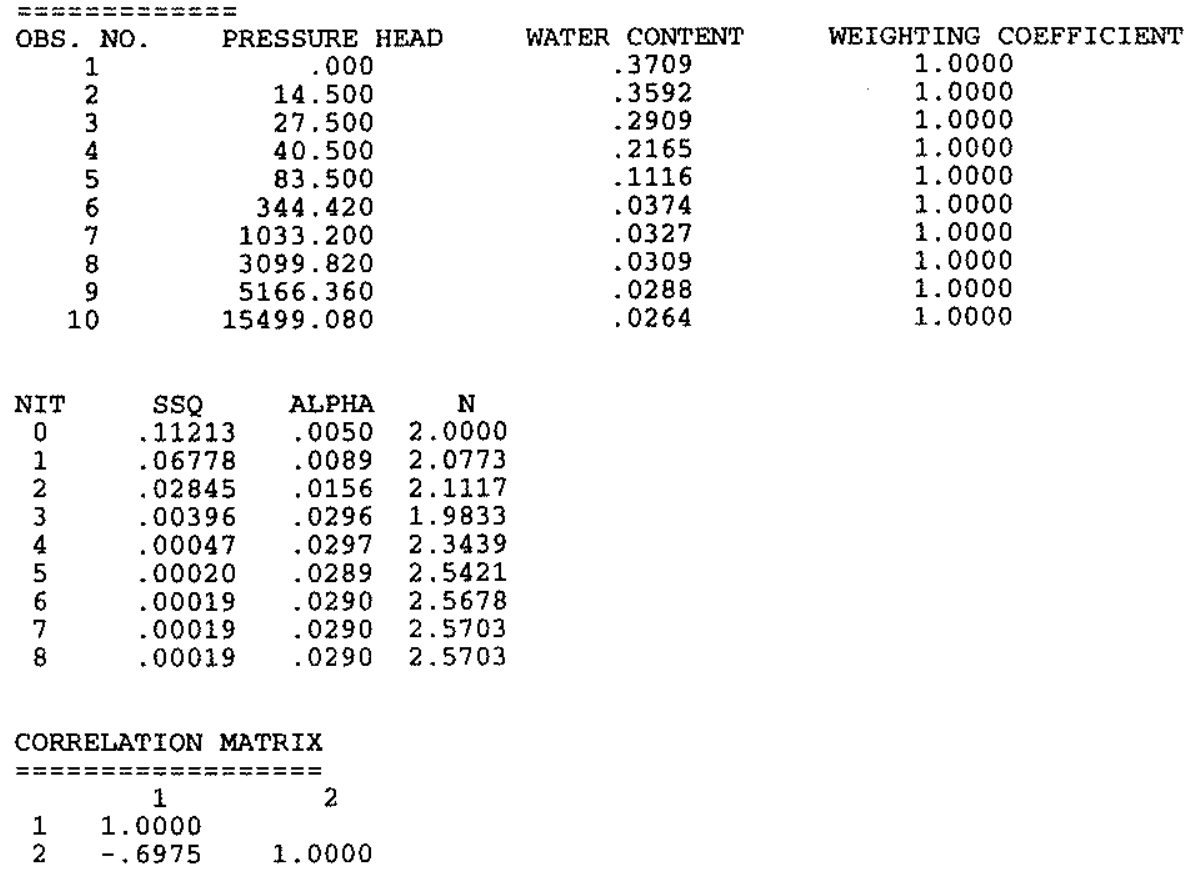

RSOUARED FOR REGRESSION OF OBSERVED VS FITTED VALUES $\overline{=} .99922368$

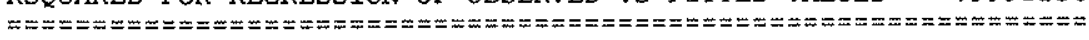

NONLINEAR LEAST-SQUARES ANALYSIS: FTNAL RESULTS

\begin{tabular}{|c|c|c|c|c|c|}
\hline & & & & CONFIDENCE & LIMITS \\
\hline $\begin{array}{l}\text { VARIABLE } \\
\text { ALPHA } \\
\text { N }\end{array}$ & $\begin{array}{l}\text { VALUE } \\
.02895 \\
2.57033\end{array}$ & $\begin{array}{l}\text { S.E.COEFF. } \\
.00074 \\
.08254\end{array}$ & $\begin{array}{r}\text { T-VALUE } \\
39.32 \\
31.14\end{array}$ & $\begin{array}{l}\text { LOWER } \\
.0273 \\
2.3800\end{array}$ & $\begin{array}{r}\text { UPPER } \\
.0306 \\
2.7606\end{array}$ \\
\hline
\end{tabular}

OBSERVED AND FITTED DATA

\begin{tabular}{|c|c|c|c|c|c|}
\hline $\begin{array}{r}\text { NO } \\
1 \\
2 \\
3 \\
4 \\
5 \\
6 \\
7 \\
8 \\
9 \\
10\end{array}$ & $\begin{array}{c}P \\
.1000 D-04 \\
.1450 D+02 \\
.2750 D+02 \\
.4050 D+02 \\
.8350 D+02 \\
.3444 D+03 \\
.1033 D+04 \\
.3100 D+04 \\
.5166 D+04 \\
.1550 D+05\end{array}$ & $\begin{array}{r}\text { LOG-P } \\
-5.0000 \\
1.1614 \\
1.4393 \\
1.6075 \\
1.9217 \\
2.5371 \\
3.0142 \\
3.4913 \\
3.7132 \\
4.1903\end{array}$ & $\begin{array}{r}\text { WC-OBS } \\
.3709 \\
.3592 \\
.2909 \\
.2165 \\
.1116 \\
.0374 \\
.0327 \\
.0309 \\
.0288 \\
.0264\end{array}$ & $\begin{array}{l}\text { WC-FTT } \\
.3709 \\
.3501 \\
.2893 \\
.2230 \\
.1075 \\
.0357 \\
.0281 \\
.0267 \\
.0265 \\
.0264\end{array}$ & $\begin{array}{r}W C-D I F \\
.0000 \\
.0091 \\
.0016 \\
.0065 \\
.0041 \\
.0017 \\
.0046 \\
.0042 \\
.0023 \\
.0000\end{array}$ \\
\hline
\end{tabular}


SUM OF SOUARES OF OBSERVED VERSUS FTTTED VALUES

\begin{tabular}{|c|c|c|c|}
\hline & & UNWEIGHTED & WEIGHTED \\
\hline RETENTION & DATA & .00019 & \\
\hline COND/DIFF & DATA & .00000 & 0 \\
\hline
\end{tabular}

SOIL HYDRAULIC PROPERTIES (MTYPE = 3)

\begin{tabular}{|c|c|c|c|c|c|c|}
\hline $\begin{array}{c}W C \\
.0286 \\
.0307 \\
.0350 \\
.0436 \\
.0522 \\
.0609 \\
.0695 \\
.0781 \\
.0867 \\
.0953 \\
.1039 \\
.1125 \\
.1211 \\
.1298 \\
.1384 \\
.1470 \\
.1556 \\
.1642 \\
.1728 \\
.1814 \\
.1900 \\
.1987 \\
.2073 \\
.2159 \\
.2245 \\
.2331 \\
.2417 \\
.2503 \\
.2589 \\
.2676 \\
.2762 \\
.2848 \\
.2934 \\
.3020 \\
.3106 \\
.3192 \\
.3278 \\
.3365 \\
.3451 \\
.3537 \\
.3623 \\
.3666 \\
.3709\end{array}$ & $\begin{array}{c}\mathrm{P} \\
.8748 \mathrm{D}+03 \\
.5625 \mathrm{D}+03 \\
.3615 \mathrm{D}+03 \\
.2321 \mathrm{D}+03 \\
.1788 \mathrm{D}+03 \\
.1483 \mathrm{D}+03 \\
.1282 \mathrm{D}+03 \\
.1136 \mathrm{D}+03 \\
.1024 \mathrm{D}+03 \\
.9351 \mathrm{D}+02 \\
.8620 \mathrm{D}+02 \\
.8004 \mathrm{D}+02 \\
.7475 \mathrm{D}+02 \\
.7014 \mathrm{D}+02 \\
.6606 \mathrm{D}+02 \\
.6241 \mathrm{D}+02 \\
.5912 \mathrm{D}+02 \\
.5611 \mathrm{D}+02 \\
.5335 \mathrm{D}+02 \\
.5080 \mathrm{D}+02 \\
.4842 \mathrm{D}+02 \\
.4618 \mathrm{D}+02 \\
.4408 \mathrm{D}+02 \\
.4208 \mathrm{D}+02 \\
.4017 \mathrm{D}+02 \\
.3834 \mathrm{D}+02 \\
.3657 \mathrm{D}+02 \\
.3486 \mathrm{D}+02 \\
.3319 \mathrm{D}+02 \\
.3156 \mathrm{D}+02 \\
.2994 \mathrm{D}+02 \\
.2834 \mathrm{D}+02 \\
.2674 \mathrm{D}+02 \\
.2512 \mathrm{D}+02 \\
.2346 \mathrm{D}+02 \\
.2176 \mathrm{D}+02 \\
.1996 \mathrm{D}+02 \\
.1804 \mathrm{D}+02 \\
.1590 \mathrm{D}+02 \\
.1339 \mathrm{D}+02 \\
.1009 \mathrm{D}+02 \\
.7656 \mathrm{D}+01 \\
.0000 \mathrm{D}+00\end{array}$ & $\begin{array}{l}\text { LOGP } \\
2.942 \\
2.750 \\
2.558 \\
2.366 \\
2.252 \\
2.171 \\
2.108 \\
2.055 \\
2.010 \\
1.971 \\
1.935 \\
1.903 \\
1.874 \\
1.846 \\
1.820 \\
1.795 \\
1.772 \\
1.749 \\
1.727 \\
1.706 \\
1.685 \\
1.654 \\
1.644 \\
1.624 \\
1.604 \\
1.584 \\
1.563 \\
1.542 \\
1.521 \\
1.499 \\
1.476 \\
1.452 \\
1.427 \\
1.400 \\
1.370 \\
1.338 \\
1.300 \\
1.256 \\
1.201 \\
1.127 \\
1.004 \\
.884\end{array}$ & $\begin{array}{l}\text { COND } \\
.4519 \mathrm{D}-12 \\
.6182 \mathrm{D}-11 \\
.8460 \mathrm{D}-10 \\
.1159 \mathrm{D}-08 \\
.5369 \mathrm{D}-08 \\
.1595 \mathrm{D}-07 \\
.3718 \mathrm{D}-07 \\
.7432 \mathrm{D}-07 \\
.1337 \mathrm{D}-06 \\
.2225 \mathrm{D}-06 \\
.3492 \mathrm{D}-06 \\
.5233 \mathrm{D}-06 \\
.7554 \mathrm{D}-06 \\
.1057 \mathrm{D}-05 \\
.1443 \mathrm{D}-05 \\
.1925 \mathrm{D}-05 \\
.2522 \mathrm{D}-05 \\
.3252 \mathrm{D}-05 \\
.4133 \mathrm{D}-05 \\
.5188 \mathrm{D}-05 \\
.6441 \mathrm{D}-05 \\
.7920 \mathrm{D}-05 \\
.9654 \mathrm{D}-05 \\
.1168 \mathrm{D}-04 \\
.1403 \mathrm{D}-04 \\
.1675 \mathrm{D}-04 \\
.1989 \mathrm{D}-04 \\
.2351 \mathrm{D}-04 \\
.2766 \mathrm{D}-04 \\
.3242 \mathrm{D}-04 \\
.3789 \mathrm{D}-04 \\
.4416 \mathrm{D}-04 \\
.5136 \mathrm{D}-04 \\
.5965 \mathrm{D}-04 \\
.6923 \mathrm{D}-04 \\
.8036 \mathrm{D}-04 \\
.9341 \mathrm{D}-04 \\
.1089 \mathrm{D}-03 \\
.1277 \mathrm{D}-03 \\
.1512 \mathrm{D}-03 \\
.1832 \mathrm{D}-03 \\
.2057 \mathrm{D}-03 \\
.2515 \mathrm{D}-03\end{array}$ & $\begin{array}{l}\text { LOGK } \\
-12.345 \\
-11.209 \\
-10.073 \\
-8.936 \\
-8.270 \\
-7.797 \\
-7.430 \\
-7.129 \\
-6.874 \\
-6.653 \\
-6.457 \\
-6.281 \\
-6.122 \\
-5.976 \\
-5.841 \\
-5.715 \\
-5.598 \\
-5.488 \\
-5.384 \\
-5.285 \\
-5.191 \\
-5.101 \\
-5.015 \\
-4.933 \\
-4.853 \\
-4.776 \\
-4.701 \\
-4.629 \\
-4.558 \\
-4.489 \\
-4.421 \\
-4.355 \\
-4.289 \\
-4.224 \\
-4.160 \\
-4.095 \\
-4.030 \\
-3.963 \\
-3.894 \\
-3.820 \\
-3.737 \\
-3.687 \\
-3.599\end{array}$ & $\begin{array}{c}\text { DrF } \\
.1170 \mathrm{D}-06 \\
.5146 \mathrm{D}-06 \\
.2267 \mathrm{D}-05 \\
.1002 \mathrm{D}-04 \\
.2400 \mathrm{D}-04 \\
.4477 \mathrm{D}-04 \\
.7288 \mathrm{D}-04 \\
.1089 \mathrm{D}-03 \\
.1534 \mathrm{D}-03 \\
.2072 \mathrm{D}-03 \\
.2709 \mathrm{D}-03 \\
.3454 \mathrm{D}-03 \\
.4317 \mathrm{D}-03 \\
.5310 \mathrm{D}-03 \\
.6444 \mathrm{D}-03 \\
.7734 \mathrm{D}-03 \\
.9198 \mathrm{D}-03 \\
.1085 \mathrm{D}-02 \\
.1273 \mathrm{D}-02 \\
.1484 \mathrm{D}-02 \\
.1723 \mathrm{D}-02 \\
.1993 \mathrm{D}-02 \\
.2299 \mathrm{D}-02 \\
.2646 \mathrm{D}-02 \\
.3041 \mathrm{D}-02 \\
.3492 \mathrm{D}-02 \\
.4009 \mathrm{D}-02 \\
.4606 \mathrm{D}-02 \\
.5299 \mathrm{D}-02 \\
.6110 \mathrm{D}-02 \\
.7069 \mathrm{D}-02 \\
.8214 \mathrm{D}-02 \\
.9602 \mathrm{D}-02 \\
.1131 \mathrm{D}-01 \\
.1347 \mathrm{D}-01 \\
.1628 \mathrm{D}-01 \\
.2006 \mathrm{D}-01 \\
.2547 \mathrm{D}-01 \\
.3386 \mathrm{D}-01 \\
.4893 \mathrm{D}-01 \\
.8632 \mathrm{D}-01 \\
.1447 \mathrm{D}+00\end{array}$ & $\begin{array}{l}\text { LOGD } \\
-6.932 \\
-6.289 \\
-5.645 \\
-4.999 \\
-4.620 \\
-4.349 \\
-4.137 \\
-3.963 \\
-3.814 \\
-3.684 \\
-3.567 \\
-3.462 \\
-3.365 \\
-3.275 \\
-3.191 \\
-3.112 \\
-3.036 \\
-2.964 \\
-2.895 \\
-2.829 \\
-2.764 \\
-2.700 \\
-2.638 \\
-2.577 \\
-2.517 \\
-2.457 \\
-2.397 \\
-2.337 \\
-2.276 \\
-2.214 \\
-2.151 \\
-2.085 \\
-2.018 \\
-1.946 \\
-1.871 \\
-1.788 \\
-1.698 \\
-1.594 \\
-1.470 \\
-1.310 \\
-1.064 \\
-.840\end{array}$ \\
\hline
\end{tabular}

ENDD OF PROBLEM 


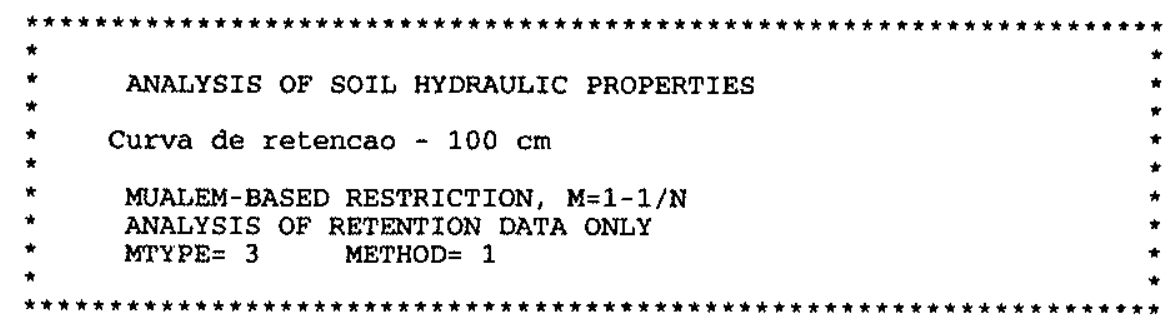

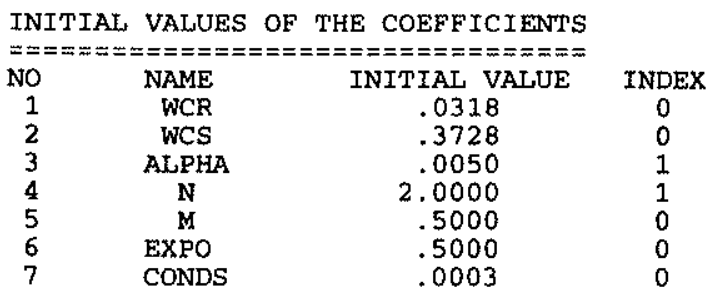

OBSERVED DATA
$\dddot{O}=== \pm= \pm===== \pm$

$\begin{array}{cccc}m==\pi=m=== & & \\ \text { OBS. NO. } & \text { PRESSURE HEAD } & \text { WATER CONTENT } & \text { WEIGHTING COEFFICIENT } \\ 1 & .000 & .3728 & 1.0000 \\ 2 & 14.500 & .3586 & 1.0000 \\ 3 & 27.500 & .2681 & 1.0000 \\ 4 & 40.500 & .1975 & 1.0000 \\ 5 & 83.500 & .1077 & 1.0000 \\ 6 & 344.420 & .0407 & 1.0000 \\ 7 & 1033.200 & .0376 & 1.0000 \\ 8 & 3099.820 & .0350 & 1.0000 \\ 9 & 5166.360 & .0338 & 1.0000 \\ 10 & 15499.080 & .0318 & 1.0000\end{array}$

$\begin{array}{cllc}\text { NIT } & \text { SSQ } & \text { ALPHA } & \text { N } \\ 0 & .12623 & .0050 & 2.0000 \\ 1 & .07986 & .0090 & 2.0650 \\ 2 & .03569 & .0164 & 2.0840 \\ 3 & .00691 & .0333 & 1.8807 \\ 4 & .00082 & .0353 & 2.2281 \\ 5 & .00040 & .0326 & 2.4921 \\ 6 & .00034 & .0332 & 2.5247 \\ 7 & .00034 & .0331 & 2.5337 \\ 9 & .00034 & .0331 & 2.5336\end{array}$

$$
\begin{aligned}
& \text { CORRELATION MATRIX }
\end{aligned}
$$

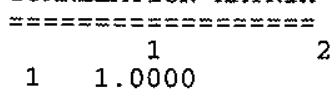

$$
\begin{aligned}
& \begin{array}{lll}
1 & 1.0000 & \\
2 & -.7408 & 1.0000
\end{array}
\end{aligned}
$$

RSQUARED FOR REGRESSION OF OBSERVED VS FITTED VALUES $=.99834239$

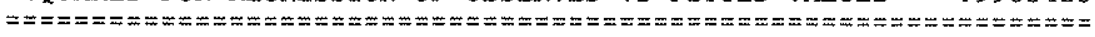

NONLINEAR IJEAST-SQUARES ANALYSIS: FINAL RESULTS

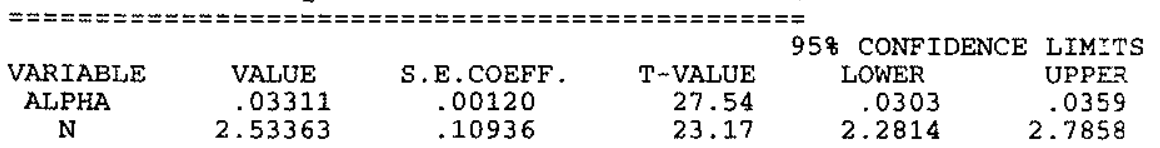

OBSERVED AND FITTED DATA

\begin{tabular}{|c|c|c|c|c|c|}
\hline $\begin{array}{r}\text { No } \\
1 \\
2 \\
3 \\
4 \\
5 \\
6 \\
7 \\
8 \\
9 \\
10\end{array}$ & $\begin{array}{c}\mathrm{p} \\
.1000 \mathrm{D}-04 \\
.1450 \mathrm{D}+02 \\
.2750 \mathrm{D}+02 \\
4050 \mathrm{D}+02 \\
.8350 \mathrm{D}+02 \\
.3444 \mathrm{D}+03 \\
.1033 \mathrm{D}+04 \\
.3100 \mathrm{D}+04 \\
.5166 \mathrm{D}+04 \\
.1550 \mathrm{D}+05\end{array}$ & $\begin{array}{r}\text { LOG-P } \\
-5.0000 \\
1.1614 \\
1.4393 \\
1.6075 \\
1.9217 \\
2.5371 \\
3.0142 \\
3.4913 \\
3.7132 \\
4.1903\end{array}$ & $\begin{array}{r}\text { WC-OBS } \\
.3728 \\
.3586 \\
.2681 \\
.1975 \\
.1077 \\
.0407 \\
.0376 \\
.0350 \\
.0338 \\
.0318\end{array}$ & $\begin{array}{r}\text { WC-FIT } \\
.3728 \\
.3442 \\
.2716 \\
.2036 \\
.1004 \\
.0399 \\
.0333 \\
.0321 \\
.0319 \\
.0318\end{array}$ & $\begin{array}{r}\text { WC-DIF } \\
.0000 \\
.0144 \\
-.0035 \\
-.0061 \\
.0073 \\
.0008 \\
.0043 \\
.0029 \\
.0019 \\
.0000\end{array}$ \\
\hline
\end{tabular}


SUM OF SQUARES OF OBSERVED VERSUS FITTED VALUES

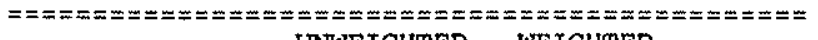

$\begin{array}{rcr} & \text { UNWEIGHTED } & \text { WEIGHTED } \\ \text { RETENTION DATA } & .00034 & .00034 \\ \text { COND/DIFF DATA } & .00000 & .00000 \\ \text { ALL DATA } & .00034 & .00034\end{array}$

SOIL HYDRAULIC PROPERTIES (MTYPE $=3$ )

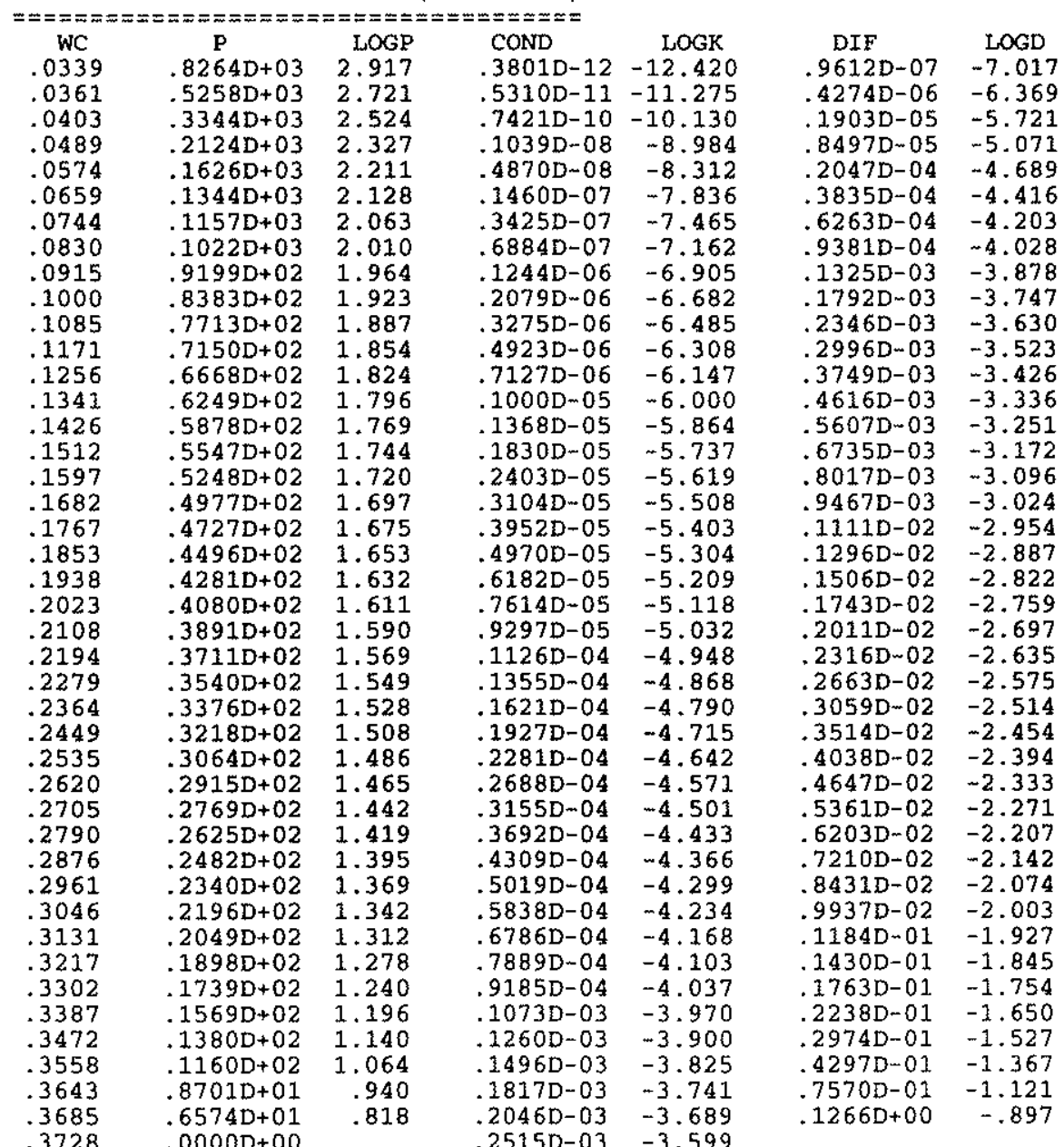




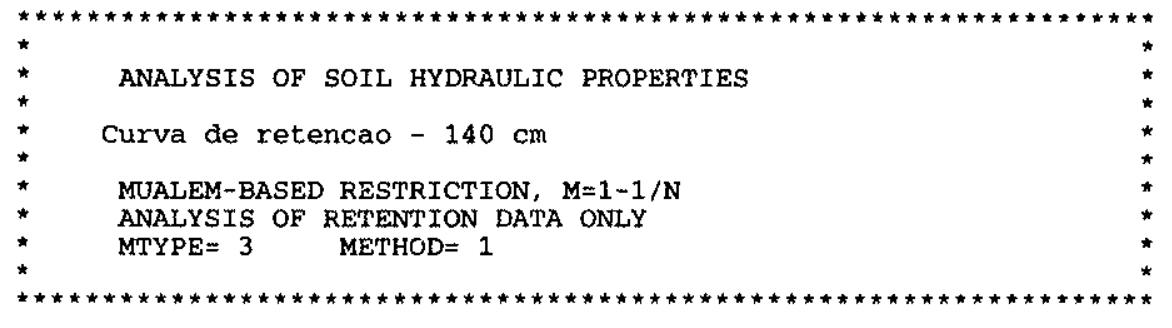

INITIAL VALUES OF THE COEFFICIENTS

\begin{tabular}{|c|c|c|c|}
\hline NO & NAME & INITIAL VALUE & INDEX. \\
\hline 1 & WCR & .0349 & 0 \\
\hline$\overline{2}$ & WCS & .3926 & 0 \\
\hline 3 & ALPHA & .0050 & 1 \\
\hline 4 & $\mathrm{~N}$ & 2.0000 & 1 \\
\hline 5 & M & .5000 & 0 \\
\hline 6 & EXPO & .5000 & 0 \\
\hline 7 & CONDS & .0003 & 0 \\
\hline
\end{tabular}

OBSERVED DATA

$= \pm=========$ =

OBS. NO. PRESSURE HEAD WATER CONTENT WEIGHTING COEFFICIENT

$\begin{array}{rrrr}1 & .000 & .3926 & 1.0000 \\ 2 & 14.500 & .3702 & 1.0000 \\ 3 & 27.500 & .3057 & 1.0000 \\ 4 & 40.500 & .2339 & 1.0000 \\ 5 & 83.500 & .1391 & 1.0000 \\ 6 & 344.420 & .0507 & 1.0000 \\ 7 & 1033.200 & .0396 & 1.0000 \\ 8 & 3099.820 & .0388 & 1.0000 \\ 9 & 5166.360 & .0366 & 1.0000 \\ 10 & 15499.080 & .0349 & 1.0000\end{array}$

$\begin{array}{cllc}\text { NIT } & \text { SSQ } & \text { ALPHA } & \text { N } \\ 0 & .11282 & .0050 & 2.0000 \\ 1 & .06776 & .0088 & 2.0872 \\ 2 & .02929 & .0151 & 2.1156 \\ 3 & .00489 & .0288 & 1.9009 \\ 4 & .00029 & .0321 & 2.1516 \\ 5 & .00014 & .0304 & 2.2916 \\ 6 & .00014 & .0306 & 2.3007 \\ 7 & .00014 & .0306 & 2.3017 \\ 8 & .00014 & .0306 & 2.3017\end{array}$

CORRELATION MATRIX

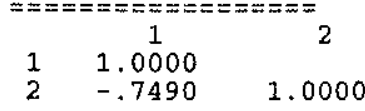

RSQUARED FOR REGRESSION OF OBSERVED VS FITTED VALUES $=.99935872$

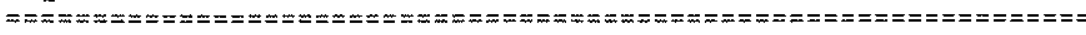

NONLINEAR IUEAST-SQUARES ANALYSIS: FINAL RESULTS

\begin{tabular}{|c|c|c|c|c|c|}
\hline & & & & $95 \%$ CONFIDENCE & LIMITS \\
\hline $\begin{array}{l}\text { VARIABLE } \\
\text { ALPHA } \\
N\end{array}$ & $\begin{array}{c}\text { VALUE } \\
.03056 \\
2.30170\end{array}$ & $\begin{array}{l}\text { S.E.COEFF. } \\
\quad .00075 \\
.05471\end{array}$ & $\begin{array}{r}\text { T-VALUE } \\
40.84 \\
42.07\end{array}$ & $\begin{array}{r}\text { LOWER } \\
.0288 \\
2.1755\end{array}$ & $\begin{array}{l}\text { UPPER } \\
.0323 \\
2.4279\end{array}$ \\
\hline
\end{tabular}

OBSERVED AND FITTED DATA

\begin{tabular}{|c|c|c|c|c|c|}
\hline $\begin{array}{r}\text { NO } \\
1 \\
2 \\
3 \\
4 \\
5 \\
6 \\
7 \\
8 \\
9 \\
10\end{array}$ & $\begin{array}{c}\mathrm{P} \\
.1000 \mathrm{D}-04 \\
.1450 \mathrm{D}+02 \\
.2750 \mathrm{D}+02 \\
.4050 \mathrm{D}+02 \\
.8350 \mathrm{D}+02 \\
.3444 \mathrm{D}+03 \\
.1033 \mathrm{D}+04 \\
.3100 \mathrm{D}+04 \\
.5166 \mathrm{D}+04 \\
.1550 \mathrm{D}+05\end{array}$ & $\begin{array}{r}\text { LOG }-P \\
-5.0000 \\
1.1614 \\
1.4393 \\
1.6075 \\
1.9217 \\
2.5371 \\
3.0142 \\
3.4913 \\
3.7132 \\
4.1903\end{array}$ & $\begin{array}{r}W C-O B S \\
.3926 \\
.3702 \\
.3057 \\
.2339 \\
.1391 \\
.0507 \\
.0396 \\
.0388 \\
.0366 \\
.0349\end{array}$ & $\begin{array}{r}\text { WC-FIT } \\
.3926 \\
.3648 \\
.3025 \\
.2417 \\
.1342 \\
.0516 \\
.0389 \\
.0359 \\
.0354 \\
.0350\end{array}$ & $\begin{array}{r}\text { WC-DIF } \\
.0000 \\
.0054 \\
.0032 \\
-.0078 \\
.0049 \\
.0009 \\
.0007 \\
.0029 \\
.0012 \\
-.0001\end{array}$ \\
\hline
\end{tabular}


SUM OF SQUARES OF OBSERVED VERSUS FITTED VALUES

\begin{tabular}{|c|c|c|c|}
\hline & & UNWEIGHTED & WEIGHTE \\
\hline RETENT & DATA & .00014 & \\
\hline COND/ & DATA & .00000 & \\
\hline ALL & DATA & .00014 & \\
\hline
\end{tabular}

SOIL HYLRAULIC PROPERTIES (MTYPE = 3)

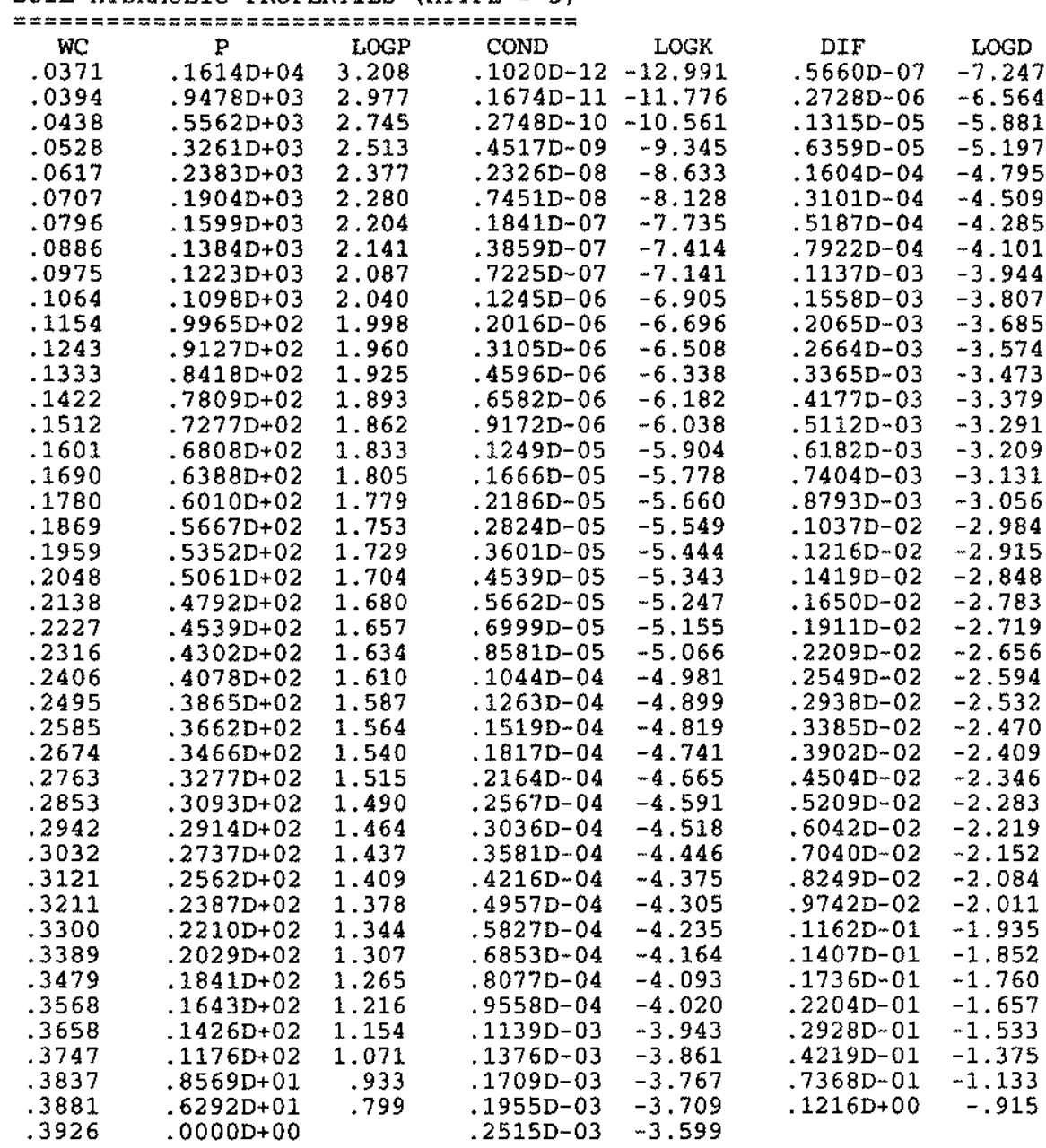




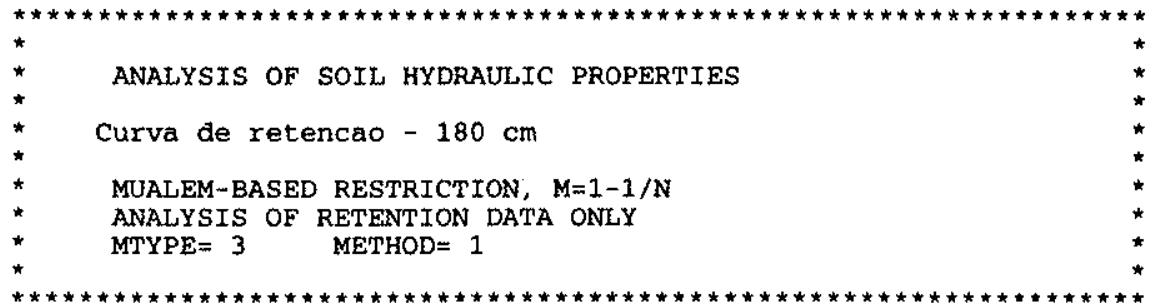

INTTIAI, VALUES OF THE COEFFICIENTS

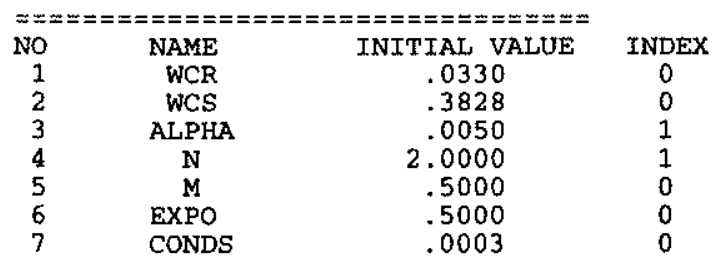

OBSERVED DATA

OBS. NO. PRESSURE HEAD

$\begin{array}{rr}1 & .000 \\ 2 & 14.500 \\ 3 & 27.500 \\ 4 & 40.500 \\ 5 & 83.500 \\ 6 & 344.420 \\ 7 & 1033.200 \\ 8 & 3099.820 \\ 9 & 5166.360 \\ 10 & 15499.080\end{array}$

WATER CONTENT

.3828

.3326

.3273

.2893

.2002

.0496

.0398

.0373

.0363

.0330
WEIGHTING COEFFICIEN

$$
\begin{aligned}
& 1.0000 \\
& 1.0000 \\
& 1.0000 \\
& 1.0000 \\
& 1.0000 \\
& 1.0000 \\
& 1.0000 \\
& 1.0000 \\
& 1.0000 \\
& 1.0000
\end{aligned}
$$

\begin{tabular}{|c|c|c|c|c|c|}
\hline & & & & 958 CONFIDENCE & E LIMIMS \\
\hline VARIABLE & VALUE & S.E.COEFF. & T-VALUE & LOWER & UPPER \\
\hline ALPHA & .02290 & .00231 & 9.91 & .0176 & .0282 \\
\hline $\mathrm{N}$ & 2.08216 & .15842 & 13.14 & 1.7169 & 2.4475 \\
\hline
\end{tabular}

\begin{tabular}{|c|c|c|c|c|c|}
\hline $\begin{array}{r}\text { NO } \\
1 \\
2 \\
3 \\
4 \\
5 \\
6 \\
7 \\
8 \\
9 \\
10\end{array}$ & $\begin{array}{c}\mathrm{P} \\
.1000 \mathrm{D}-04 \\
.1450 \mathrm{D}+02 \\
.2750 \mathrm{D}+02 \\
.4050 \mathrm{D}+02 \\
.8350 \mathrm{D}+02 \\
.3444 \mathrm{D}+03 \\
.1033 \mathrm{D}+04 \\
.3100 \mathrm{D}+04 \\
.5166 \mathrm{D}+04 \\
.1550 \mathrm{D}+05\end{array}$ & $\begin{array}{r}\text { LOG-P } \\
-5.0000 \\
1.1614 \\
1.4393 \\
1.6075 \\
1.9217 \\
2.5371 \\
3.0142 \\
3.4913 \\
3.7132 \\
4.1903\end{array}$ & $\begin{array}{r}\text { WC-OBS } \\
.3828 \\
.3326 \\
.3273 \\
.2893 \\
.2002 \\
.0496 \\
.0398 \\
.0373 \\
.0363 \\
.0330\end{array}$ & $\begin{array}{r}\text { WC-FIT } \\
.3828 \\
.3658 \\
.3287 \\
.2867 \\
.1869 \\
.0702 \\
.0444 \\
.0365 \\
.0350 \\
.0336\end{array}$ & $\begin{array}{r}\text { WC-DIF } \\
.0000 \\
-.0332 \\
-.0014 \\
.0026 \\
.0133 \\
-.0206 \\
-.0046 \\
.0008 \\
.0013 \\
-.0006\end{array}$ \\
\hline
\end{tabular}

$\begin{array}{clcc}\text { NIT } & \text { SSQ } & \text { ALPHA } & \text { N } \\ 0 & .06618 & .0050 & 2.0000 \\ 1 & .03288 & .0082 & 2.1429 \\ 2 & .01175 & .0183 & 1.7352 \\ 3 & .00193 & .0246 & 1.9500 \\ 4 & .00174 & .0229 & 2.0762 \\ 5 & .00173 & .0229 & 2.0836 \\ 6 & .00173 & .0229 & 2.0820 \\ 7 & .00173 & .0229 & 2.0822 \\ 8 & .00173 & .0229 & 2.0822\end{array}$

\section{CORRELATTON MATRIX}

$$
\begin{array}{ccc}
==m========== \\
& 1 & 2 \\
1 & 1.0000 & \\
2 & -.7193 & 1.0000
\end{array}
$$

RSOUARED FOR REGRESSION OF OBSERVED VS FITTED VALUES $=.99241611$

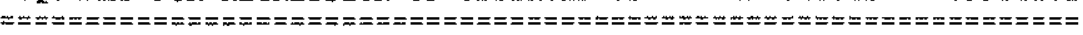

NONLINEAR LEAST-SQUARES ANALYSIS: FINAL RESULTS

\section{OBSERVED AND FITTED DATA}


SUM OF SQUARES OF OBSERVED VERSUS FITTED VALUES

\begin{tabular}{|c|c|c|c|}
\hline & & UNWEIGHTED & WEIGHTED \\
\hline $\begin{array}{l}\text { RETENTION } \\
\text { COND/DIFF }\end{array}$ & $\begin{array}{l}\text { DATA } \\
\text { DATA }\end{array}$ & .00173 & .00173 \\
\hline
\end{tabular}

ALL DATA $\quad .00173 \quad .00173$

SOIL HYDRAULIC PROPERTIES (MPYPE = 3)

\begin{tabular}{|c|c|c|c|c|c|c|}
\hline $\begin{array}{c}W C \\
.0352 \\
.0374 \\
.0417 \\
.0505 \\
.0592 \\
.0680 \\
.0767 \\
.0855 \\
.0942 \\
.1030 \\
.1117 \\
.1205 \\
.1292 \\
.1379 \\
.1467 \\
.1554 \\
.1642 \\
.1729 \\
.1817 \\
.2904 \\
.1992 \\
.2079 \\
.2166 \\
.2254 \\
.2341 \\
.2429 \\
.2516 \\
.2604 \\
.2691 \\
.2779 \\
.2866 \\
.2954 \\
.3041 \\
.3128 \\
.3216 \\
.3303 \\
.3391 \\
.3478 \\
.3566 \\
.3653 \\
.3741 \\
.3828\end{array}$ & $\begin{array}{c}\mathrm{P} \\
.4753 \mathrm{D}+04 \\
.2505 \mathrm{D}+04 \\
.1320 \mathrm{D}+04 \\
.6947 \mathrm{D}+03 \\
.4768 \mathrm{D}+03 \\
.3646 \mathrm{D}+03 \\
.2957 \mathrm{D}+03 \\
.2489 \mathrm{D}+03 \\
.2149 \mathrm{D}+03 \\
.1890 \mathrm{D}+03 \\
.1685 \mathrm{D}+03 \\
.1519 \mathrm{D}+03 \\
.1381 \mathrm{D}+03 \\
.1264 \mathrm{D}+03 \\
.1164 \mathrm{D}+03 \\
.1076 \mathrm{D}+03 \\
.9990 \mathrm{D}+02 \\
.9304 \mathrm{D}+02 \\
.8689 \mathrm{D}+02 \\
.8131 \mathrm{D}+02 \\
.7622 \mathrm{D}+02 \\
.7155 \mathrm{D}+02 \\
.6723 \mathrm{D}+02 \\
.6321 \mathrm{D}+02 \\
.5944 \mathrm{D}+02 \\
.5590 \mathrm{D}+02 \\
.5255 \mathrm{D}+02 \\
.4937 \mathrm{D}+02 \\
.4632 \mathrm{D}+02 \\
.4338 \mathrm{D}+02 \\
.4054 \mathrm{D}+02 \\
.3778 \mathrm{D}+02 \\
.3506 \mathrm{D}+02 \\
.3238 \mathrm{D}+02 \\
.2970 \mathrm{D}+02 \\
.2699 \mathrm{D}+02 \\
.2422 \mathrm{D}+02 \\
.2132 \mathrm{D}+02 \\
.1821 \mathrm{D}+02 \\
.1471 \mathrm{D}+02 \\
.1035 \mathrm{D}+02 \\
.7355 \mathrm{D}+01 \\
.0000 \mathrm{D}+00\end{array}$ & $\begin{array}{l}\text { LOGP } \\
3.677 \\
3.399 \\
3.120 \\
2.842 \\
2.678 \\
2.562 \\
2.471 \\
2.396 \\
2.332 \\
2.276 \\
2.227 \\
2.182 \\
2.140 \\
2.102 \\
2.066 \\
2.032 \\
2.000 \\
1.969 \\
1.939 \\
1.910 \\
1.882 \\
1.855 \\
1.828 \\
1.801 \\
1.774 \\
1.747 \\
1.721 \\
1.693 \\
1.666 \\
1.637 \\
1.608 \\
1.577 \\
1.545 \\
1.510 \\
1.473 \\
1.431 \\
1.384 \\
1.329 \\
1.260 \\
1.168 \\
1.015 \\
.867\end{array}$ & $\begin{array}{l}\text { COND } \\
.1771 \mathrm{D}-13 \\
.3607 \mathrm{D}-12 \\
.7349 \mathrm{D}-11 \\
.1499 \mathrm{D}-09 \\
.8752 \mathrm{D}-09 \\
.3065 \mathrm{D}-08 \\
.8113 \mathrm{D}-08 \\
.1799 \mathrm{D}-07 \\
.3533 \mathrm{D}-07 \\
.6345 \mathrm{D}-07 \\
.1065 \mathrm{D}-06 \\
.1695 \mathrm{D}-06 \\
.2583 \mathrm{D}-06 \\
.3801 \mathrm{D}-06 \\
.5430 \mathrm{D}-06 \\
.7565 \mathrm{D}-06 \\
.1031 \mathrm{D}-05 \\
.1381 \mathrm{D}-05 \\
.1819 \mathrm{D}-05 \\
.2362 \mathrm{D}-05 \\
.3029 \mathrm{D}-05 \\
.3841 \mathrm{D}-05 \\
.4825 \mathrm{D}-05 \\
.6008 \mathrm{D}-05 \\
.7423 \mathrm{D}-05 \\
.9108 \mathrm{D}-05 \\
.1111 \mathrm{D}-04 \\
.1348 \mathrm{D}-04 \\
.1627 \mathrm{D}-04 \\
.1957 \mathrm{D}-04 \\
.2347 \mathrm{D}-04 \\
.2806 \mathrm{D}-04 \\
.3349 \mathrm{D}-04 \\
.3993 \mathrm{D}-04 \\
.4761 \mathrm{D}-04 \\
.5683 \mathrm{D}-04 \\
.6803 \mathrm{D}-04 \\
.8186 \mathrm{D}-04 \\
.9939 \mathrm{D}-04 \\
.1227 \mathrm{D}-03 \\
.1568 \mathrm{D}-03 \\
.1833 \mathrm{D}-03 \\
.2515 \mathrm{D}-03\end{array}$ & $\begin{array}{l}\text { LOGK } \\
-13.752 \\
-12.443 \\
-11.134 \\
-9.824 \\
-9.058 \\
-8.514 \\
-8.091 \\
-7.745 \\
-7.452 \\
-7.198 \\
-6.973 \\
-6.771 \\
-6.588 \\
-6.420 \\
-6.265 \\
-6.121 \\
-5.987 \\
-5.860 \\
-5.740 \\
-5.627 \\
-5.519 \\
-5.416 \\
-5.317 \\
-5.221 \\
-5.129 \\
-5.041 \\
-4.954 \\
-4.870 \\
-4.788 \\
-4.708 \\
-4.630 \\
-4.552 \\
-4.475 \\
-4.399 \\
-4.322 \\
-4.245 \\
-4.167 \\
-4.087 \\
-4.003 \\
-3.911 \\
-3.805 \\
-3.737 \\
-3.599\end{array}$ & $\begin{array}{c}\text { DIF } \\
.3558 \mathrm{D}-07 \\
.1910 \mathrm{D}-06 \\
.1026 \mathrm{D}-05 \\
.5518 \mathrm{D}-05 \\
.1480 \mathrm{D}-04 \\
.2988 \mathrm{D}-04 \\
.5165 \mathrm{D}-04 \\
.8098 \mathrm{D}-04 \\
.1188 \mathrm{D}-03 \\
.1659 \mathrm{D}-03 \\
.2234 \mathrm{D}-03 \\
.2923 \mathrm{D}-03 \\
.3739 \mathrm{D}-03 \\
.4694 \mathrm{D}-03 \\
.5803 \mathrm{D}-03 \\
.7084 \mathrm{D}-03 \\
.8555 \mathrm{D}-03 \\
.1024 \mathrm{D}-02 \\
.1217 \mathrm{D}-02 \\
.1436 \mathrm{D}-02 \\
.1686 \mathrm{D}-02 \\
.1972 \mathrm{D}-02 \\
.2297 \mathrm{D}-02 \\
.2669 \mathrm{D}-02 \\
.3094 \mathrm{D}-02 \\
.3583 \mathrm{D}-02 \\
.4146 \mathrm{D}-02 \\
.4799 \mathrm{D}-02 \\
.5560 \mathrm{D}-02 \\
.6454 \mathrm{D}-02 \\
.7514 \mathrm{D}-02 \\
.8784 \mathrm{D}-02 \\
.1033 \mathrm{D}-01 \\
.1223 \mathrm{D}-01 \\
.1463 \mathrm{D}-01 \\
.1775 \mathrm{D}-01 \\
.2195 \mathrm{D}-01 \\
.2792 \mathrm{D}-01 \\
.3711 \mathrm{D}-01 \\
.5339 \mathrm{D}-01 \\
.9251 \mathrm{D}-01 \\
.1508 \mathrm{D}+00\end{array}$ & $\begin{array}{l}\text { LOGD } \\
-7.449 \\
-6.719 \\
-5.989 \\
-5.258 \\
-4.830 \\
-4.525 \\
-4.287 \\
-4.092 \\
-3.925 \\
-3.780 \\
-3.651 \\
-3.534 \\
-3.427 \\
-3.329 \\
-3.236 \\
-3.150 \\
-3.068 \\
-2.990 \\
-2.915 \\
-2.843 \\
-2.773 \\
-2.705 \\
-2.639 \\
-2.574 \\
-2.509 \\
-2.446 \\
-2.382 \\
-2.319 \\
-2.255 \\
-2.190 \\
-2.124 \\
-2.056 \\
-1.986 \\
-1.913 \\
-1.835 \\
-1.751 \\
-1.659 \\
-1.554 \\
-1.430 \\
-1.273 \\
-1.034 \\
-.822\end{array}$ \\
\hline
\end{tabular}




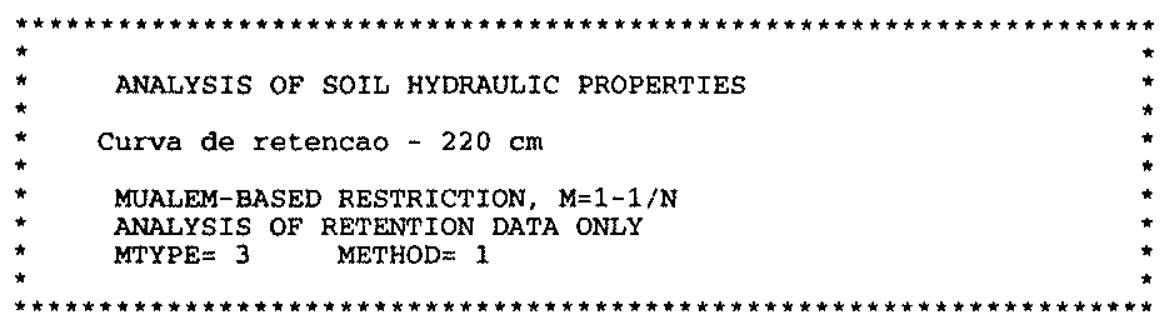

INITIAL VALUES OF THE COEFFICIENTS

\begin{tabular}{|c|c|c|c|}
\hline NO & NAME & INITIAL VALUE & INDEX \\
\hline 1 & WCR & .0328 & 0 \\
\hline 2 & WCS & .4076 & 0 \\
\hline 3 & ALPHA & .0050 & 1 \\
\hline 4 & $\mathbf{N}$ & 2.0000 & 1 \\
\hline 5 & M & .5000 & 0 \\
\hline 6 & EXPO & .5000 & 0 \\
\hline 7 & CONDS & .0003 & 0 \\
\hline
\end{tabular}

OBSERVED DATA

ㅆ = = = = = = = = = =

$\begin{array}{cccc}\text { OBS. NO. } & \text { PRESSURE HEAD } & \text { WATER CONTENT } & \text { WEIGHTING COEFFICIENT } \\ 1 & .000 & .4076 & 1.0000 \\ 2 & 14.500 & .3694 & 1.0000 \\ 3 & 27.500 & .2976 & 1.0000 \\ 4 & 40.500 & .2374 & 1.0000 \\ 5 & 83.500 & .1406 & 1.0000 \\ 6 & 344.420 & .0487 & 1.0000 \\ 7 & 1033.200 & .0382 & 1.0000 \\ 8 & 3099.820 & .0368 & 1.0000 \\ 9 & 5166.360 & .0350 & 1.0000 \\ 10 & 15499.080 & .0328 & 1.0000\end{array}$

$\begin{array}{clcc}\text { NIT } & \text { SSQ } & \text { ALPHA } & \text { N } \\ 0 & .13049 & .0050 & 2.0000 \\ 1 & .08021 & .0088 & 2.0811 \\ 2 & .03609 & .0153 & 2.1004 \\ 3 & .00757 & .0302 & 1.8269 \\ 4 & .00021 & .0367 & 2.0295 \\ 5 & .00006 & .0343 & 2.1517 \\ 6 & .00005 & .0346 & 2.1574 \\ 7 & .00005 & .0346 & 2.1572 \\ 8 & .00005 & .0346 & 2.1572\end{array}$

CORRELATION MATRIX

$$
\begin{array}{ccc}
= & ==== \pm== \pm== \pm== \\
& 1 & 2 \\
1 & 1.0000 & \\
2 & m .7876 & 1.0000
\end{array}
$$

RSQUARED FOR REGRESSTON OF OBSERVED VS FITTED VALUES $=.99975405$

=:

\begin{tabular}{|c|c|c|c|c|c|}
\hline & & & & $95 \%$ CONFIDENCE & LIMITS \\
\hline $\begin{array}{l}\text { VARIABLE } \\
\text { ALPHA } \\
\text { N }\end{array}$ & $\begin{array}{l}\text { VALUE } \\
.03457 \\
2.15720\end{array}$ & $\begin{array}{l}\text { S.E.COEFF. } \\
.00055 \\
.02781\end{array}$ & $\begin{array}{r}\text { T-VALUE } \\
62.40 \\
77.58\end{array}$ & $\begin{array}{l}\text { LOWER } \\
.0333 \\
2.0931\end{array}$ & $\begin{array}{r}\text { UPPER } \\
.0359 \\
2.2213\end{array}$ \\
\hline
\end{tabular}

NONLINEAR LEAST-SQUARES ANALYSIS: FINAL RESULTS

\begin{tabular}{|c|c|c|c|c|c|}
\hline $\begin{array}{r}\text { NO } \\
1 \\
2 \\
3 \\
4 \\
5 \\
6 \\
7 \\
8 \\
9 \\
10\end{array}$ & $\begin{array}{c}\mathrm{P} \\
.1000 \mathrm{D}-04 \\
.1450 \mathrm{D}+02 \\
.2750 \mathrm{D}+02 \\
.4050 \mathrm{D}+02 \\
.8350 \mathrm{D}+02 \\
.3444 \mathrm{D}+03 \\
.1033 \mathrm{D}+04 \\
.3100 \mathrm{D}+04 \\
.5166 \mathrm{D}+04 \\
.1550 \mathrm{D}+05\end{array}$ & $\begin{array}{r}\text { LOG-P } \\
-5.0000 \\
1.1614 \\
1.4393 \\
1.6075 \\
1.9217 \\
2.5371 \\
3.0142 \\
3.4913 \\
3.7132 \\
4.1903\end{array}$ & $\begin{array}{r}\text { WC-OBS } \\
.4076 \\
.3694 \\
.2976 \\
.2374 \\
.1406 \\
.0487 \\
.0382 \\
.0368 \\
.0350 \\
.0328\end{array}$ & $\begin{array}{r}\text { WC-FIT } \\
.4076 \\
.3689 \\
.2987 \\
.2382 \\
.1371 \\
.0541 \\
.0388 \\
.0345 \\
.0337 \\
.0331\end{array}$ & $\begin{array}{r}W C-D I F \\
.0000 \\
.0005 \\
-.0011 \\
-.0008 \\
.0035 \\
-.0054 \\
-.0006 \\
.0023 \\
.0013 \\
-.0003\end{array}$ \\
\hline
\end{tabular}

OBSERVED AND FITTED DATA 
SUM OF SQUARES OF OBSERVED VERSUS FITTED VALUES

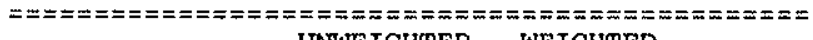

RETENTION DATA UNWE 00005 . 00005

COND/DIFF DATA $\quad .00000 \quad .00000$

ALL DATA $\quad .00005 \quad .00005$

SOIL HYDRAULIC PRORERTTES (MTYPE = 3)

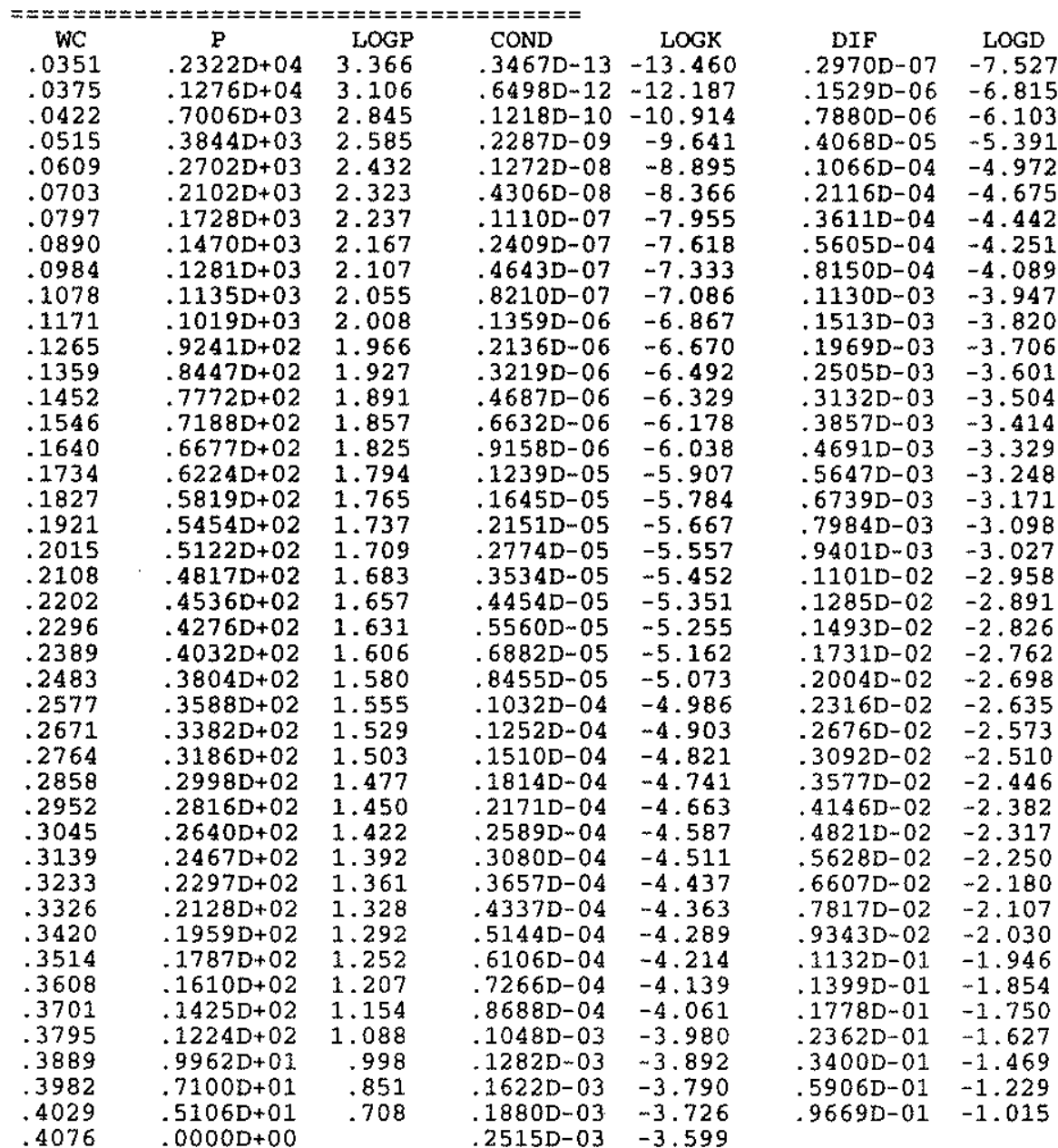


ANEXO 3 
Tabela 3 - Análises químicas dos lisímetros de sucção (valores médios)

\begin{tabular}{|c|c|c|c|c|c|c|c|}
\hline \multirow[t]{2}{*}{ Parâmetro } & \multirow[t]{2}{*}{ Área } & \multirow[t]{2}{*}{ Profundidade $(\mathrm{cm})$} & \multicolumn{5}{|c|}{ concentração (mg/) } \\
\hline & & & $22 / 11 / 89$ & $13 / 12 / 89$ & $3 / 01 / 90$ & $31 / 01 / 90$ & $15 / 03 / 90$ \\
\hline \multirow[t]{15}{*}{ Potássio } & \multirow[t]{5}{*}{ Área 1} & 40 & 6,10 & 2,10 & 7,50 & 2,00 & 3,25 \\
\hline & & 80 & 9,00 & 1,30 & 0,93 & 0,65 & 0,21 \\
\hline & & 120 & 2,00 & 3,50 & 1,50 & 1,35 & 0,20 \\
\hline & & 160 & 5,30 & & 1,30 & 1,05 & 0,04 \\
\hline & & 200 & 2,90 & & 2,15 & 1,50 & 0,12 \\
\hline & \multirow[t]{5}{*}{ Area 2} & 40 & 6,10 & 1,10 & 4,20 & & 0,20 \\
\hline & & 80 & 9,00 & 2,10 & 1,00 & 9,10 & 0,20 \\
\hline & & 120 & 2,00 & & 1,40 & 1,10 & 0,20 \\
\hline & & 160 & 5,30 & 1,10 & 0,95 & 0,40 & 0,20 \\
\hline & & 200 & 2,90 & 18,50 & 3,90 & 6,55 & 0,45 \\
\hline & \multirow[t]{5}{*}{ Área 3} & 40 & 6,10 & 10,70 & 1,25 & 15,00 & 4,35 \\
\hline & & 80 & 9,00 & 29,00 & 12,40 & & 17,00 \\
\hline & & 120 & 2,00 & 13,00 & 2,10 & 2,50 & \\
\hline & & 160 & 5,30 & 2,25 & 1,90 & 0,40 & 0,15 \\
\hline & & 200 & 2,90 & & 1,73 & 2,30 & 0,16 \\
\hline \multirow[t]{15}{*}{$\mathrm{DOC}$} & \multirow[t]{5}{*}{ Área 1} & 40 & 48,90 & 278,00 & 365,50 & 15,10 & 525,70 \\
\hline & & 80 & 42,50 & 202,00 & 175,30 & 27,80 & 340,30 \\
\hline & & 120 & 48,60 & 211,00 & 172,70 & 256,60 & 492,00 \\
\hline & & 160 & 24,10 & 213,00 & 56,60 & 23,55 & 42,70 \\
\hline & & 200 & 19,80 & & 28,85 & 25,50 & 8,55 \\
\hline & \multirow[t]{5}{*}{ Área 2} & 40 & 48,90 & 228,00 & 269,70 & & 273,00 \\
\hline & & 80 & 42,50 & 135,00 & 160,50 & 7,65 & 188,00 \\
\hline & & 120 & 48,60 & & 167,00 & 485,30 & 102,50 \\
\hline & & 160 & 24,10 & 172,00 & 70,85 & 35,20 & 23,75 \\
\hline & & 200 & 19,80 & 46,43 & 58,97 & 276,30 & 8,05 \\
\hline & \multirow[t]{5}{*}{ Area 3} & 40 & 48,90 & 266,00 & 238,50 & 228,00 & 316,50 \\
\hline & & 80 & 42,50 & 49,70 & 153,50 & & 104,75 \\
\hline & & 120 & 48,60 & 296,00 & 186,87 & 94,35 & \\
\hline & & 160 & 24,10 & 169,50 & 137,50 & 18,65 & 12,80 \\
\hline & & 200 & 19,80 & 22,60 & 53,97 & 12,43 & 7,67 \\
\hline \multirow[t]{15}{*}{$\mathrm{N}-\mathrm{NO} 3$} & \multirow[t]{5}{*}{ Area 1} & 40 & 0,05 & 0,20 & 0,80 & 0,05 & \\
\hline & & 80 & 0,02 & 0,30 & 0,60 & 0,03 & \\
\hline & & 120 & 0,06 & 0,30 & 0,57 & 0,53 & \\
\hline & & 160 & 0,02 & 0,22 & 1,16 & 0,06 & 0,01 \\
\hline & & 200 & 0,16 & & 0,08 & 0,04 & 0,20 \\
\hline & \multirow[t]{5}{*}{ Área 2} & 40 & 0,05 & 1,00 & 0,77 & & \\
\hline & & 80 & 0,02 & 0,10 & 0,43 & 0,04 & \\
\hline & & 120 & 0,06 & & 0,42 & 0,21 & \\
\hline & & 160 & 0,02 & 0,18 & 0,04 & 0,29 & 0,02 \\
\hline & & 200 & 0,16 & 0.90 & 1,08 & 1,28 & 0,28 \\
\hline & \multirow[t]{5}{*}{ Área 3} & 40 & 0,05 & 0,35 & 0,55 & 0,03 & \\
\hline & & 80 & 0,02 & 1,04 & 0,39 & & \\
\hline & & 120 & 0,06 & 1,20 & 0,46 & 0,24 & \\
\hline & & 160 & 0,02 & 0,10 & 1,17 & 0,16 & 0,44 \\
\hline & & 200 & 0,16 & 0,06 & 0,02 & 0,17 & 0,50 \\
\hline
\end{tabular}


Tabela 3 (continuação)

\begin{tabular}{|c|c|c|c|c|c|c|c|}
\hline \multirow[t]{2}{*}{ Parâmetro } & \multirow[t]{2}{*}{ Área } & \multirow[t]{2}{*}{ Profundidade $(\mathrm{cm})$} & \multicolumn{5}{|c|}{ concentração (mg/l) } \\
\hline & & & $22 / 11 / 89$ & $13 / 12 / 89$ & $3 / 01 / 90$ & $31 / 01 / 90$ & $15 / 03 / 90$ \\
\hline \multirow[t]{15}{*}{ NKT } & \multirow[t]{5}{*}{ Área 1} & 40 & 1,10 & 4,50 & 2,75 & 10,00 & 3,50 \\
\hline & & 80 & 1,00 & 5,50 & 3,33 & 2,00 & 2,37 \\
\hline & & 120 & 0,60 & 4,00 & 3,13 & 2,10 & 1,50 \\
\hline & & 160 & 0,70 & 3,30 & 0,30 & 0,20 & 0,50 \\
\hline & & 200 & 0,90 & & 0,40 & 0,47 & 0,20 \\
\hline & \multirow[t]{5}{*}{ Área 2} & 40 & 1,10 & 7,00 & 3,33 & & 5,00 \\
\hline & & 80 & 1,00 & 1,10 & 3,00 & 0,55 & 0,30 \\
\hline & & 120 & 0,60 & & 0,22 & 1,20 & 0,35 \\
\hline & & 160 & 0,70 & 3,30 & 0,35 & 0,25 & 0,25 \\
\hline & & 200 & 0,90 & 3,07 & 0,37 & 0,50 & 0,25 \\
\hline & \multirow[t]{5}{*}{ Área 3} & 40 & 1,10 & 8,75 & 3,20 & 6,00 & 3,50 \\
\hline & & 80 & 1,00 & 3,00 & 2,00 & & 0,35 \\
\hline & & 120 & 0,60 & 6.50 & 2,60 & 5,50 & \\
\hline & & 160 & 0,70 & 2,35 & 3,93 & 0,40 & 0,50 \\
\hline & & 200 & 0,90 & 2,50 & 0,33 & 0,40 & 0,27 \\
\hline \multirow[t]{15}{*}{ N-NH4 } & \multirow[t]{5}{*}{ Area 1} & 40 & 0,37 & 1,20 & 0,85 & 0,07 & 0,29 \\
\hline & & 80 & 0,10 & 0,50 & 0,58 & 0,07 & 0,39 \\
\hline & & 120 & 0,18 & 0,50 & 0,80 & 0,07 & 0,42 \\
\hline & & 160 & 0,09 & 0,16 & 0,13 & 0,13 & 0,44 \\
\hline & & 200 & 0,09 & & 0,10 & 0,12 & 0,14 \\
\hline & \multirow[t]{5}{*}{ Area 2} & 40 & 0,37 & 0,80 & 1,17 & & 0,24 \\
\hline & & 80 & 0,10 & 0,25 & 0,98 & 0,06 & 0,23 \\
\hline & & 120 & 0,18 & & 0,70 & 0,07 & 0,19 \\
\hline & & 160 & 0,09 & 0,23 & 0,09 & 0,06 & 0,17 \\
\hline & & 200 & 0,09 & 0,13 & 0,09 & 0,11 & 0,09 \\
\hline & \multirow[t]{5}{*}{ Área 3} & 40 & 0,37 & 0,63 & 0,50 & 0,06 & 0,47 \\
\hline & & 80 & 0,10 & 0,16 & 0,48 & & 0,27 \\
\hline & & 120 & 0,18 & 0,45 & 0,48 & 0,07 & \\
\hline & & 160 & 0,09 & 0,17 & 0,58 & 0,18 & 0,39 \\
\hline & & 200 & 0,09 & 0,08 & 0,09 & 0,11 & 0,11 \\
\hline \multirow[t]{15}{*}{ Cloreto } & \multirow[t]{5}{*}{ Area 1} & 40 & 61,50 & 700,00 & 307,50 & 19,00 & \\
\hline & & 80 & 34,00 & 450,00 & 300,00 & 50,00 & \\
\hline & & 120 & 133,00 & 375,00 & 245,00 & 49,00 & \\
\hline & & 160 & 8,00 & 480,00 & & 9,50 & 8,50 \\
\hline & & 200 & 4,25 & & 5,50 & 12,50 & 7,50 \\
\hline & \multirow[t]{5}{*}{ Área 2} & 40 & 61,50 & 50,00 & 128,33 & & \\
\hline & & 80 & 34,00 & 435,00 & 44,00 & 24,50 & \\
\hline & & 120 & 133,00 & & 455,00 & 11,50 & \\
\hline & & 160 & 8,00 & 430,00 & 2,00 & 22,25 & 2,50 \\
\hline & & 200 & 4,25 & 146,75 & 7,25 & 19,50 & 7,25 \\
\hline & \multirow[t]{5}{*}{ Área 3} & 40 & 61,50 & 139,25 & 138,25 & 15,50 & \\
\hline & & 80 & 34,00 & 300,00 & 5,00 & & \\
\hline & & 120 & 133,00 & 420,00 & 260,00 & 21,75 & \\
\hline & & 160 & 8,00 & 510,00 & & 16.50 & 4,17 \\
\hline & & 200 & 4,25 & 11,00 & 9,00 & 25,33 & 10,50 \\
\hline
\end{tabular}


Tabela 3 (continuação)

\begin{tabular}{|c|c|c|c|c|c|c|c|}
\hline \multirow[t]{2}{*}{ Parâmetro } & \multirow[t]{2}{*}{ Área } & \multirow[t]{2}{*}{ Profundidade $(\mathrm{cm})$} & \multicolumn{5}{|c|}{ concentração $(\mathrm{mg} / \mathrm{d})$} \\
\hline & & & $22 / 11 / 89$ & $13 / 12 / 89$ & $3 / 01 / 90$ & $31 / 01 / 90$ & $15 / 03 / 90$ \\
\hline \multirow{15}{*}{ Sulfato } & \multirow{5}{*}{ Área 1} & 40 & & & 79.00 & 688.00 & 154.33 \\
\hline & & 80 & & & 302.67 & 1305.00 & 611,00 \\
\hline & & 120 & & & 315,50 & 930,00 & 295.00 \\
\hline & & 160 & & & 362,00 & 24.00 & 31.00 \\
\hline & & 200 & & & & 33.50 & nd \\
\hline & \multirow[t]{5}{*}{ Área 2} & 40 & & & 222.50 & & 170.00 \\
\hline & & 80 & & & 974.00 & 420.00 & 5.00 \\
\hline & & 120 & & & 920.33 & 333.00 & 435.50 \\
\hline & & 160 & & & 30.00 & 38.00 & 149.00 \\
\hline & & 200 & & & 35.00 & 306.50 & 13.00 \\
\hline & \multirow[t]{5}{*}{ Área 3} & 40 & & & 189.50 & 379.00 & 104,00 \\
\hline & & 80 & & & & & 271.00 \\
\hline & & 120 & & & 724.00 & 304,00 & \\
\hline & & 160 & & & 552000 & 37.00 & nd \\
\hline & & 200 & & & 95.00 & 103.50 & nd \\
\hline
\end{tabular}


Tabela 4 - Análises químicas dos poços de monitoramento com filtro longo e multiníveis

\begin{tabular}{|c|c|c|c|c|c|c|c|c|c|}
\hline Data & Equipamento & $\begin{array}{c}\mathrm{Cl} \\
\mathrm{mg} / \mathrm{l}\end{array}$ & $\begin{array}{c}\mathrm{N}-\mathrm{NH} 4 \\
\mathrm{mg} / 1\end{array}$ & $\begin{array}{c}\mathrm{N}-, \mathrm{NO} 3 \\
\mathrm{mg} / \mathrm{l}\end{array}$ & $\begin{array}{l}\text { NKT } \\
\mathrm{mg} / \mathrm{l} \\
\end{array}$ & $\begin{array}{c}\mathrm{K} \\
\mathrm{mg} / \mathrm{l}\end{array}$ & $\begin{array}{l}\mathrm{SO} 4 \\
\mathrm{mg} / 1\end{array}$ & $\begin{array}{l}\mathrm{DOC} \\
\mathrm{mg} / 1\end{array}$ & $\begin{array}{l}\text { Norg } \\
\mathrm{mg} / 1 \\
\end{array}$ \\
\hline $22 / 11 / 89$ & P1 & 0,50 & 0,10 & 0,90 & 0,70 & 1,20 & nd & 7,80 & 0,60 \\
\hline $22 / 11 / 89$ & $\mathbf{P 2}$ & 2,00 & 0,08 & 0,44 & 0,60 & 0,40 & nd & 7,00 & 0,52 \\
\hline $22 / 11 / 89$ & P3 & + & - & - & - & - & - & - & - \\
\hline $22 / 11 / 89$ & P4 & - & - & - & - & - & - & - & - \\
\hline $22 / 11 / 89$ & P5 & 0,50 & 0,11 & 0,66 & 0,80 & 0,30 & 7,00 & 7,20 & 0,69 \\
\hline $22 / 11 / 89$ & $\mathrm{P} 6$ & 0,50 & 0,07 & 0,20 & 0,50 & 1,20 & 15,00 & 7,20 & 0,43 \\
\hline $22 / 11 / 89$ & $\mathrm{MN} 1-\mathrm{S}$ & - & - & - & - & - & $\therefore$ & - & - \\
\hline $22 / 11 / 89$ & $\mathrm{MN} 1-\mathrm{P}$ & - & 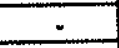 & - & $=$ & - & - & - & - \\
\hline $22 / 11 / 89$ & $\mathrm{MN} 2, \mathrm{~S}$ & $=$ & - & $=$ & - & $=$ & 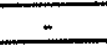 & $=$ & 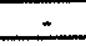 \\
\hline $22 / 11 / 89$ & $\mathrm{MN} 2, \mathrm{P}$ & - & $\approx$ & - & - & - & 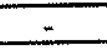 & - & $=$ \\
\hline $22 / 11 / 89$ & $\mathrm{MN} 3-, \mathrm{S}$ & $\because$ & - & $=$ & - & - & - & - & 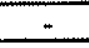 \\
\hline $22 / 11 / 89$ & $\mathrm{MN} 3-, \mathrm{P}$ & - & - & 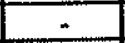 & - & - & $=$ & - & - \\
\hline $13 / 12 / 89$ & P1 & 0,50 & 0,07 & 1,00 & 0,60 & 0,30 & $*$ & 1,50 & 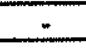 \\
\hline $13 / 12 / 89$ & $\mathrm{P2}$ & 0,50 & 0,11 & 0,44 & 0,50 & 0,30 & * & 2,10 & - \\
\hline $13 / 12 / 89$ & P3 & 0,50 & 0,08 & 0,90 & 0,60 & 0,20 & $*$ & 3,40 & - \\
\hline $13 / 12 / 89$ & P4 & 0,50 & 0,09 & 0,66 & 0,70 & 0,40 & $*$ & 2,10 & - \\
\hline $13 / 12 / 89$ & P5 & 1,00 & 0,13 & 1,00 & 0,60 & 0,20 & $*$ & 4,60 & - \\
\hline $13 / 12 / 89$ & P6 & nd & 0,09 & 0,20 & 0,60 & 0,10 & * & 2,10 & - \\
\hline $13 / 12 / 89$ & $\mathrm{MN} 1-\mathrm{S}$ & 53,00 & 0,60 & 0,40 & 1,00 & 0,50 & * & 75,80 & 0,40 \\
\hline $13 / 12 / 89$ & $\mathrm{MN} 1, \mathrm{P}$ & 2,00 & 0,10 & 0,92 & 0,80 & 0,70 & $*$ & 6,70 & 0,70 \\
\hline $13 / 12 / 89$ & $\mathrm{MN} 2-\mathrm{S}$ & 30,00 & 1,00 & 0,60 & 1,40 & 1,00 & * & 61,00 & 0,40 \\
\hline $13 / 12 / 89$ & $\mathrm{MN} 2, \mathrm{P}$ & 0,50 & 0,12 & 0,90 & 0,40 & nd & * & 5,80 & 0,28 \\
\hline $13 / 12 / 89$ & $\mathrm{MN} 3-\mathrm{S}$ & 15,00 & 0,90 & 0,60 & 1,00 & 0,40 & $*$ & 49,00 & 0,10 \\
\hline $13 / 12 / 89$ & $\mathrm{MN} 3-\mathrm{P}$ & 0,50 & 0,09 & 0,56 & 0,50 & 0,20 & $*$ & 4,00 & 0,41 \\
\hline $03 / 01 / 90$ & P1 & 1,50 & 0,06 & 0,64 & 0,20 & 0,40 & 29,00 & 2,10 & - \\
\hline $03 / 01 / 90$ & $\mathbf{P 2}$ & 1,50 & 0,10 & 0,40 & 0,30 & 0,20 & 27,00 & 2,10 & - \\
\hline $03 / 01 / 90$ & P3 & 5,00 & 0,10 & 3,40 & 0,20 & 0,40 & 54,00 & 1,50 & $=$ \\
\hline $03 / 01 / 90$ & P4 & 5,00 & 0,11 & 3,20 & 0,20 & 0,20 & 27,00 & 1,50 & - \\
\hline $03 / 01 / 90$ & $\mathrm{P} 5$ & 3,00 & 0,08 & $*$ & 0,30 & 0,20 & 27,00 & 1,50 & - \\
\hline $03 / 01 / 90$ & P6 & $*$ & 0,08 & 0,20 & 0,30 & 0,20 & 29,00 & 1,50 & - \\
\hline $03 / 01 / 90$ & $\mathrm{MN} 1-, \mathrm{S}$ & 55,00 & 0,40 & 0,05 & 2,00 & 0,90 & 283,00 & 69,00 & 1,60 \\
\hline $03 / 01 / 90$ & $\mathrm{MN} 1, \mathrm{P}$ & 0,50 & 0,08 & 0,69 & 0,50 & 0,40 & 21,00 & 4,30 & 0,42 \\
\hline $03 / 01 / 90$ & $\mathrm{MN} 2-\mathrm{S}$ & 25,00 & 0,45 & 0,05 & 6,50 & 0,40 & 27,00 & 32,00 & 6,05 \\
\hline $03 / 01 / 90$ & $\mathrm{MN} 2, \mathrm{P}$ & 2,00 & 0,09 & 0,76 & 0,40 & 0,30 & $*$ & 3,40 & 0,31 \\
\hline $03 / 01 / 90$ & $\mathrm{MN} 3-\mathrm{S}$ & 10,00 & 0,55 & 0,05 & 1,50 & 0,60 & 31,00 & 34,50 & 0,95 \\
\hline $03 / 01 / 90$ & $\mathrm{MN} 3-, \mathrm{P}$ & 2,00 & 0,09 & 0,54 & 0,30 & 0,30 & 58,00 & 2,80 & 0,21 \\
\hline $31 / 01 / 90$ & $\mathrm{Pl}$ & 1,50 & 0,09 & 0,27 & 0,20 & 0,20 & 9,00 & 2,80 & - \\
\hline $31 / 01 / 90$ & $\mathrm{P2}$ & 0,50 & 0,05 & 0,15 & 0,20 & 0,10 & 14,00 & 2,10 & - \\
\hline $31 / 01 / 90$ & P3 & - & - & - & - & - & - & - & - \\
\hline $31 / 01 / 90$ & P4 & 1,50 & 0,08 & 1,45 & 0,20 & 0,10 & 12,00 & 2,10 & $=$ \\
\hline $31 / 01 / 90$ & P5 & - & - & - & - & - & - & - & - \\
\hline $31 / 01 / 90$ & P6 & - & - & - & - & - & - & - & - \\
\hline $31 / 01 / 90$ & $\mathrm{MN} 1-\mathrm{S}$ & 3,00 & 0,04 & 0,03 & 2,00 & 3,20 & 4,00 & 2,10 & 1,96 \\
\hline $31 / 01 / 90$ & $\mathbf{M N 1}, \mathbf{p}$ & 11,00 & 0,04 & 0,42 & 0,30 & 9,40 & 13,00 & 2,10 & 0,26 \\
\hline $31 / 01 / 90$ & $\mathrm{MN} 2-\mathrm{S}$ & 2,50 & 0,04 & 0,07 & 6,00 & 0,90 & 9,00 & 2,80 & 5,96 \\
\hline $31 / 01 / 90$ & $\mathrm{MN} 2-\mathrm{P}$ & 2,50 & 0,05 & 0,53 & 0,20 & 0,30 & $<4$ & 2,10 & 0,15 \\
\hline $31 / 01 / 90$ & $\mathrm{MN} 3-\mathrm{S}$ & 5,00 & 0,06 & 0,01 & 0,40 & 0,70 & 12,00 & 2,80 & 0,34 \\
\hline $31 / 01 / 90$ & $\mathrm{MN} 3-\mathrm{P}$ & 3,50 & 0,06 & 0,59 & 0,20 & 2,40 & 8,00 & 2,80 & 0,14 \\
\hline $15 / 03 / 90$ & P1 & - & - & - & - & - & - & - & - \\
\hline $15 / 03 / 90$ & P2 & 0,50 & 0,10 & 0,05 & 0,30 & $<0.20$ & nd & 41,80 & - \\
\hline $15 / 03 / 90$ & $\mathrm{P3}$ & 1,00 & 0,08 & 1,74 & 0,20 & $<0.04$ & nd & 3,40 & 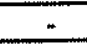 \\
\hline $15 / 03 / 90$ & P4 & 1,00 & 0,07 & 0,47 & 0,20 & 0,10 & nd & 4,00 & - \\
\hline $15 / 03 / 90$ & P5 & 3,50 & 0,13 & 0,21 & 0,20 & 0,30 & 5,00 & 4,00 & $=$ \\
\hline $15 / 03 / 90$ & P6 & 2,00 & 0,09 & 0,06 & 0,20 & $<0.04$ & nd & 5,20 & - \\
\hline $15 / 03 / 90$ & $\mathrm{MN} 1-\mathrm{S}$ & 0,50 & 0,07 & nd & 0,10 & - & 2,00 & 5,20 & 0,03 \\
\hline $15 / 03 / 90$ & $\mathrm{MN} 1-\mathrm{P}$ & 13,50 & 0,06 & 0,69 & 0,10 & 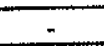 & nd & 46,00 & 0,04 \\
\hline $15 / 03 / 90$ & $\mathrm{MN} 2-\mathrm{S}$ & 0,50 & 0,07 & 0,39 & 0,10 & - & nd & 4,60 & 0,03 \\
\hline $15 / 03 / 90$ & $\mathrm{MN} 2, \mathrm{P}$ & 2,50 & 0,07 & 0,05 & 0,20 & $=$ & 10,00 & 14,60 & 0,13 \\
\hline $15 / 03 / 90$ & $\mathrm{MN} 3-, \mathrm{S}$ & 0,50 & 0,06 & 0,23 & 0,20 & - & nd & 4,00 & 0,14 \\
\hline $15 / 03 / 90$ & $\mathrm{MN} 3-, \mathrm{P}$ & 50,00 & 0,06 & 0,12 & 0,10 & - & nd & 33,20 & 0,04 \\
\hline
\end{tabular}

